Cassiano Ricardo Gomes Peres

\title{
Análise do método de custeio baseado em atividades aplicado à logística de distribuição
}

Dissertação apresentada à Escola de Engenharia de São Carlos da Universidade de São Paulo, como parte dos requisitos para obtenção do título de Mestre em Engenharia de Produção.

Orientador: Prof. Dr. Wilson Kendy Tachibana

São Carlos

2006 


\section{FOLHA DE JULGAMENTO}

\section{Candidato: Engenheiro CASSIANO RICARDO GOMES PERES}

Dissertação defendida e julgada em 12-05-2006 perante a Comissão Julgadora:

Prof. Dr. WILSON KENDY TACHIBANA (Orientador)

BProuaso

(Escola de Engenharia de São Carlos/USP)

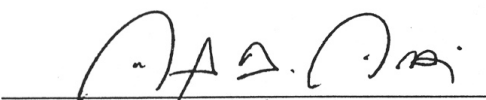

APROVAOT

Prof. Dr. MARCEL ANDREOTTI MUSETTI

(Escola de Engenharia de São Carlos /USP)

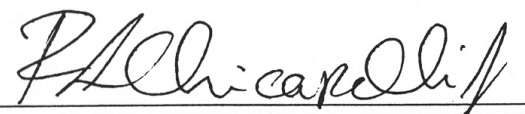

Profa. Dra. ROSANE LUCIA CHICARELLI ALCÂNTARA

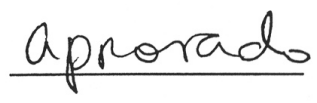

(Universidade Federal de São Carlos/UFSCar)

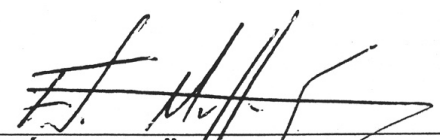

Prof. Associado FÁBIO MÜLLER GUERRINI

Coordenador do Programa de Pół-Graduação em Engenharia de Produção

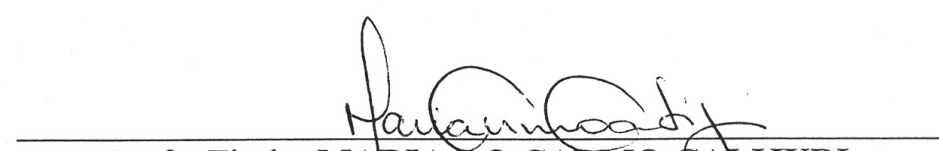

Profa. Titular MARIA DO CARMO CALIJURI

Presidente da Comissão de Pós-Graduação 
Apócrifo seria este trabalho, capital e não venial seria o pecado, caso olvidasse honras à pétrea família cujo arranjo me insere. Edwards Peres de Assis, Ormênia Gomes Peres, Marcos Humberto Gomes Peres e Camila Gomes Peres. Se não co-autores, esteio. 


\section{Agradecimentos}

Primeiramente gostaria de agradecer aqueles que diretamente colaboraram com a feitura desta dissertação. Faço honras ao professor Dr. Wilson Kendy Tachibana, que desde o primeiro contato prontificou-se em eliminar paralogismos e dúvidas. E durante estes dois anos sempre me apoiou, guiou e proferiu sugestões que fielmente refletiam suas convicções. Agradeço a bibliotecária Elena Luzia Palloni Gonçalves, que de modo gentil e apoiador sanou este trabalho de grande parte dos desacertos de forma. Também agradeço aos professores da banca, ao professor Dr. Marcel Andreotti Musetti, cujo claro entendimento sobre metodologia científica muito colaborou para realização do estudo de caso, e a professora Dr(a). Rosane Chicarelli Alcantara, cuja perspicácia científica muito facilitou a seleção dos dados utilizados.

Seguidamente gostaria de agradecer aos que possibilitaram a manufatura deste trabalho. Meus pais que sempre me apoiaram financeiramente e emocionalmente, ajuda sem a qual nunca conseguiria dar início ou termo a esta dissertação. Aos professores. Professor Dr. Antonio Freitras Rentes por indicar e fornecer material para revisão bibliográfica. Prof. Dr. Fernando Cesar Almada Santos pela publicação do artigo, que representou minha primeira produção científica. Prof. Dr. Daniel Capaldo Amaral que magistralmente edificou conceitos de metologia de pesquisa na disciplina de seminários. Prof. Dr. Fábio Müller Guerrini que me aproximou da vida burocrática acadêmica da USP, quando, para minha surpresa, sugeriu meu nome para representante discente. Aos funcionários do Departamento de Engenharia de Produção. José Luiz Donizete Chiaretto sempre disposto a ajudar, com seu jeitão lacônico. Silvana Ap. Araújo Celestini que me agüentou seguidamente usar o telefone de sua sala para fazer ligações para empresas. Luiz Fernando Ferreira, mago da informática, que todo mau funcionamento resolvia.

Por último, e mais importante, gostaria de agradecer a todos os amigos e amigas que fiz neste período. Amigos que sempre levarei em minha memória, e que pretendo dela dar voz a eles para dúvidas que minha consciência se deparar. Em especial Ana Beatriz Andrade. Agradeço a Leonardo Lobo, Luciano Schühli, Ava Brandão, Valéria Silva, Álvaro Cabrera, Alessandro Silva, Edwin Vladimir Cardoza Galdámez, Ronaldo Campos, Wagner Ratz, Marcelo Nunes, Fábio Branco, Aníbal Rossetti, Sônia Sanae, Thais Vanzella, Eugênia Dajer, Rodrigo Ikedo, Allan Silva, Márcia Freire, Jeferson Straatmann, Rafael Farias, Olívia Oiko, Ana Laura Bigaton, Flávia Vancin, Renata Maragno, Charbel Jabbour, Rodrigo Bornholdt, Felipe Lazaretti, Marlos Mangini, Igor Vilela, Daniela Macangnam, Fúlvio Temple, Henrique Mendonca, João Gilberto Zalla Filho, Ana Cláudia Fernandes Terence, Giseli Diniz de Almeida Moraes, Antônio Luiz Tonissi Migliato, Eliciane Maria da Silva, José Manoel

Souza das Neves, Percival de Castro Pasetto. E mais tantos outros, que desculpem-me a memória e o espaço, aqui não estão. 
PERES, C.R.G. (2006). Análise do método de custeio baseado em atividades aplicado à logística de distribuição. Dissertação (Mestrado) - Escola de Engenharia de São Carlos, Universidade de São Paulo, São Carlos, 2006.

Este trabalho aborda o problema da utilização do método de custeio baseado em atividades, quando aplicado à logística de distribuição, considerando o método de implementação que uma empresa pode adotar. Trata de um estudo de caso realizado em uma empresa do setor transformados de plásticos. É sabido que os métodos tradicionais de contabilidade de custos são inadequados para custear atividades logísticas, assim como cada método de atribuição de custos possui características inerentes ao processo utilizado para o rastreamento dos custos, adequadas ou não ao objeto custeado. A logística é um processo que muito influencia a criação de valor dos produtos / serviços de uma empresa, pois torna possível maximizar a integração, na cadeia de suprimentos, do fluxo de produtos / serviços e do fluxo de informações. Para planejar e controlar as atividades logísticas, de modo eficaz e eficiente, é necessário ter um acurado método de custeio destas atividades. Nesse sentido, esta pesquisa visa investigar a implementação do método de custeio baseado em atividades, as atividades de logística de distribuição. Sugere também a utilização da tecnologia de identificação por rádio frequiência, como ferramenta auxiliadora ao custeio baseado em atividades. O resultado é que a implementação do método de custeio baseado em atividades, aplicada à logística de distribuição em empresas, necessita respeitar limitações impostas pelo tempo de execução e complexidade das atividades, para que se possa alimentar eficazmente um sistema de informações de custos.

Palavras-chave: Logística. Distribuição. Custeio baseado em atividades. Implementação. 


\section{ABSTRACT}

PERES, C.R.G. (2006). Analysis of the activity based costing method applied to the logistic distribution. M. Sc. Dissertation - Escola de Engenharia de São Carlos, Universidade de São Paulo, São Carlos, 2006.

This work approaches the utilization problem of the activity based costing method, when applied to logistic distribution, considering the method of implementation that a company can adopt. It deals about a study of case realized in a company pertaining to the sector of transformed plastics. It is known that the traditional methods of accounting are inadequate to cost logistic activities. As well as, each method of cost attribution possess characteristics, inherent to the process used to track the costs, adjusted or not to the costed object. The logistic is a process that much influences in the creation of value to products / services of a company, since makes possible to maximize the integration, in the supply chain, of the flow of products/services and the flow of information. And, to plan and to control the logistic activities, in efficient and effective way, is necessary to have an accurate method to cost these activities. In this direction, this research seeks to investigate the implementation of the activity based costing method to the logistic distribution activities. As well as it suggests the use of the identification by radio frequency technology as an auxiliary tool to the activity based costing. The result is that the implementation of the activity based costing method, applied to the logistic distribution in companies needs to respect limitations imposed by the time of execution and complexity of the activities, so that it can efficiently feed an information cost system.

Key words: Logistics. Distribution. Activity based costing. Implementation. 


\section{LISTA DE FIGURAS}

Figura 1: Modelo operacional de um sistema de informações contábeis. 17

Figura 2: Os subsistemas do sistema de informações contábeis .................................... 18

Figura 3: Um sistema de gestão de custos integrado .................................................. 19

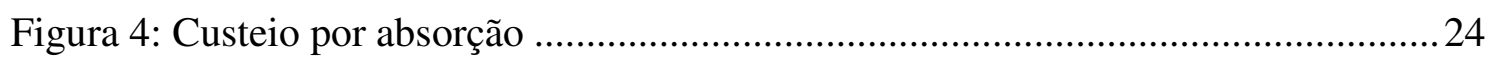

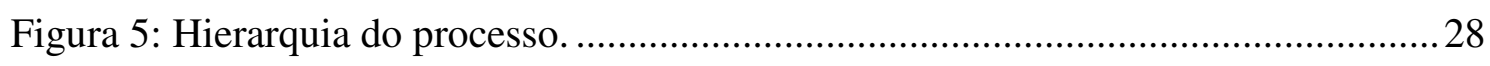

Figura 6 : Target Costing - Definições versus enfoques .............................................. 35

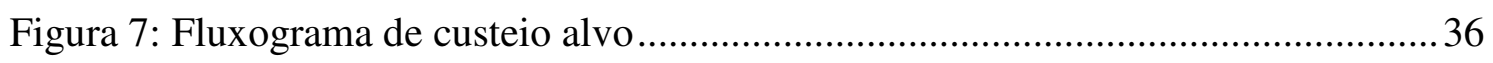

Figura 8 : Diferenças entre o target costing e sistema de custeio tradicional ................. 37

Figura 9 : Etapas do modelo de obtenção da Lucratividade Direta por Produto (DPP) .39

Figura 10 : Categorias de custos envolvidas no TCO .............................................. 41

Figura 11 : Possíveis custos relacionados com clientes .............................................. 45

Figura 12: Matriz de lucratividade por cliente ......................................................... 46

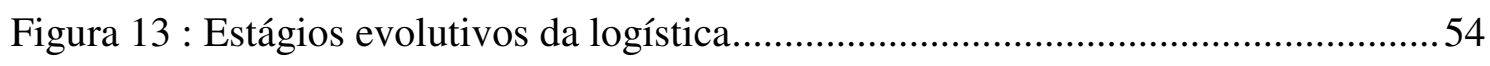

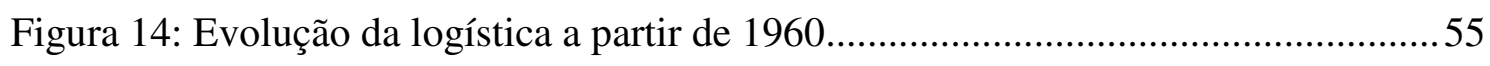

Figura 15 : Trade-offs entre soluções de embalagens e operações logísticas .................61

Figura 16 : Compensação generalizada entre receitas e custo para diversos níveis de

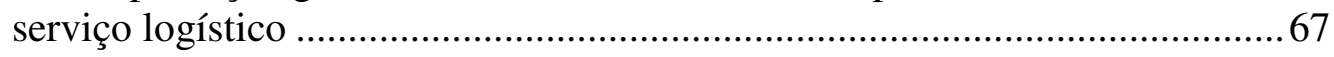

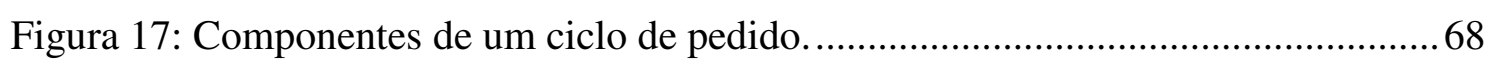

Figura 18 : Etapas físicas necessárias para criar um limpador de pára-brisa..................73

Figura 19 : Resumo das etapas físicas...................................................................... 74

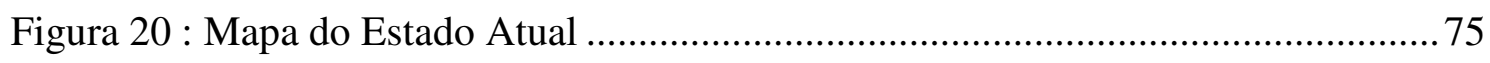

Figura 21 : Amplificação da Demanda na Montadora Alfa........................................... 78

Figura 22 : Quadro de Amplificação da Demanda no Estado Atual................................ 79

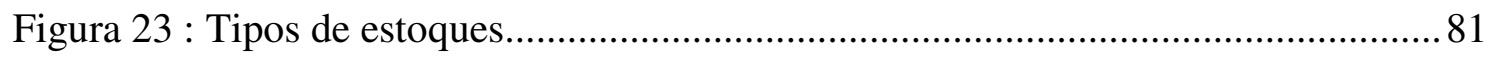

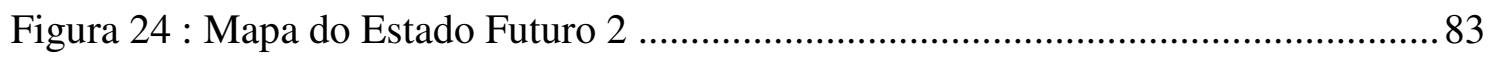

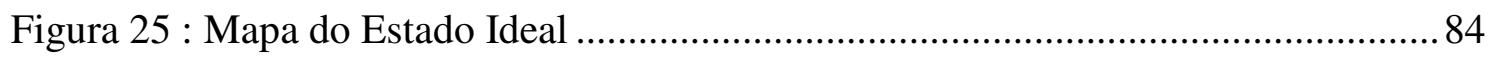

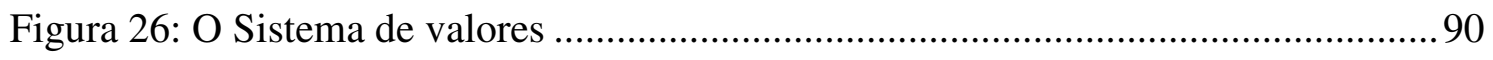

Figura 27 : A Cadeia de valores genérica ............................................................. 91

Figura 28 : Modelo de negócio baseado em processos ................................................. 93

Figura 29 : Modelo típico de processo de negócio (com subprocessos) .......................... 94

Figura 30 : Modelo de atividades com tempo e custo.................................................. 96

Figura 31 : Diagrama espinha de peixe: análise detalhada ......................................... 97 
Figura 32 : Linha do tempo do processo de manuseio de materiais do recebimento à entrega

Figura 33 : Identificação de determinantes de recursos para os departamentos 102

Figura 34 : Fatores de consumo de recursos 103

Figura 35 : Cálculo de índices de custeio de recursos para os departamentos. 103

Figura 36 : Reorganização de custos da contabilidade para atividades 104

Figura 37 - Consolidação das atividades para custeio baseado em atividades 105

Figura 38 : Fatores de consumo das atividades 106

Figura 39 : Lista de materiais 106

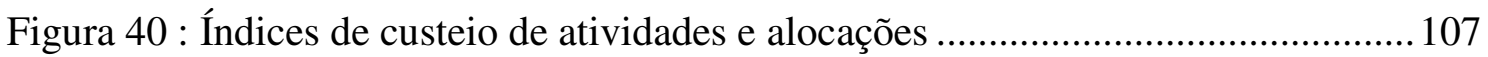

Figura 41 : Custos Indiretos Totais do ABC 108

Figura 42 : Métodos diretos e indiretos para cálculo da unidade de tempo de uma atividade

Figura 43 : Exemplo da atividade de compras - distribuição do tempo e custo

Figura 44 : As quatro categorias de portfolio implementadas na companhia do caso.. 121

Figura 45 : Classificação dos itens por variáveis escolhidas (aquisição Aq, controle de entrega $\mathrm{Ce}$, entrada de ordens $\mathrm{Oe}$, armazenagem Ar) e valores medidos (rápida $\mathrm{R}$, normal $\mathrm{N}$, lenta $\mathrm{L}$ ).

Figura 46 : O impacto do tamanho do lote de venda nos custos a seres designados para uma unidade.

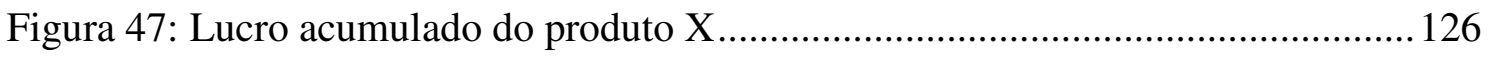

Figura 48: Lucro acumulado do produto X para cada cliente ...................................... 128

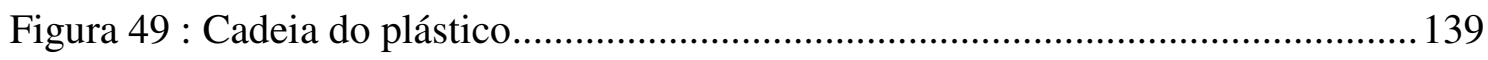

Figura 50 : Mercado de plástico brasileiro............................................................... 140

Figura 51 : Consumo aparente de artefatos transformados plásticos 2000 - 2004 - em

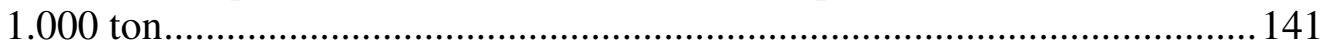

Figura 52 : Faturamento da indústria de plástico entre 2000 e 2004 em milhões.......... 142

Figura 53 : Exportações e Importações de artefatos plásticos entre 2000 e 2004 em 1000 toneladas.....

Figura 54 : Exportações e Importações de artefatos plásticos entre 2000 e 2004 em US\$ milhões

Figura 55 : Participação do setor plástico no PIB nacional .......................................... 143

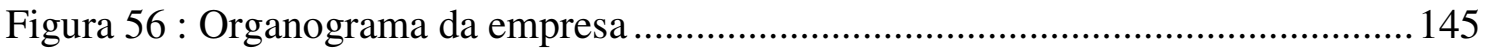

Figura 57 : Organograma da unidade Rio Claro ............................................................ 149

Figura 58 : Organograma do centro de distribuiçãa....................................................... 150

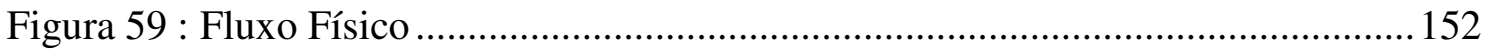

Figura 60 : Subprocessos do centro de distribuição mapeados pela empresa................ 153 
Figura 61: Fluxograma de atividades do Centro de Distribuição. 154

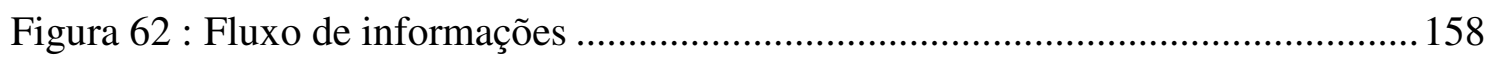

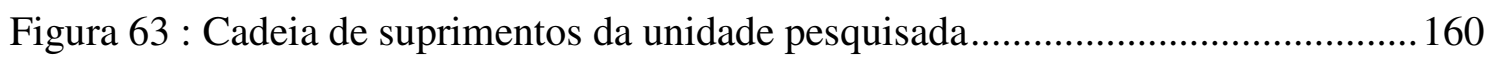

Figura 64 : Gráficos sobre tempo de ciclo e $\mathrm{n}^{\mathbf{0}}$ de carregamentos ................................ 172

Figura 65 : Participação do processo de extrusão no faturamento (Kg) do ano de 2005

Figura 66 : Participação do processo de injeção no faturamento $(\mathrm{Kg})$ do ano de 2005174 Figura 67 : Custos totais da unidade de análise ......................................................... 175

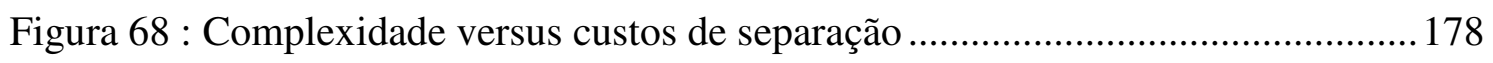

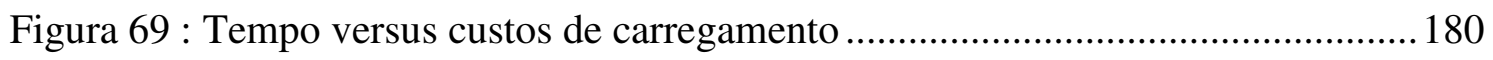

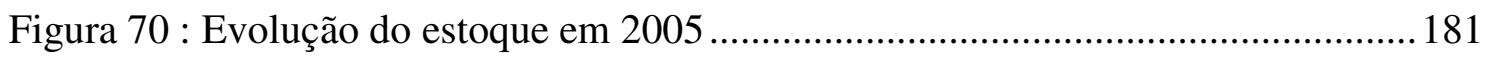

Figura 71 : Aplicação de identificação por rádio freqüência na cadeia de suprimentos 


\section{LISTA DE TABELAS}

Tabela 1: Custo Padrão das não conformidades da Northrop Aircraft Division. 42

Tabela 3: Direcionadores e atividades operacionais 49

Tabela 4 : Geradores de custos 105

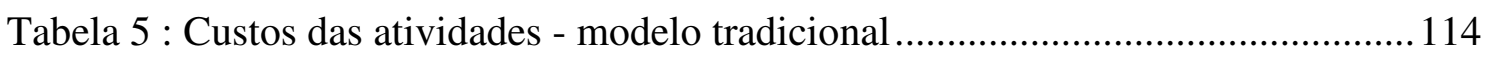

Tabela 6 : Custos das atividades - modelo dirigido pelo tempo .................................. 114

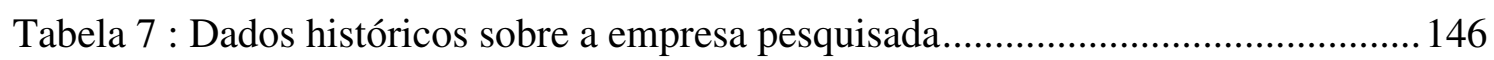

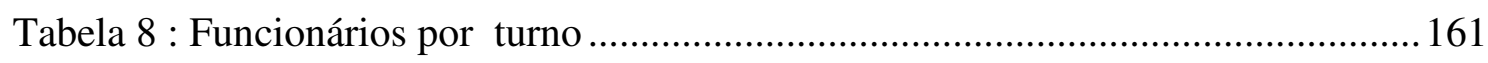

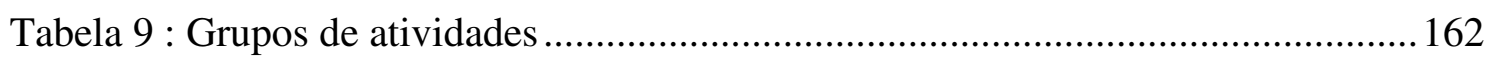

Tabela 10 : Contas do centro de distribuição para 2005 ............................................. 164

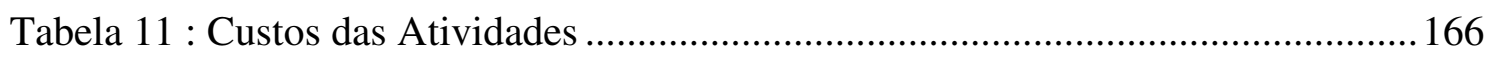

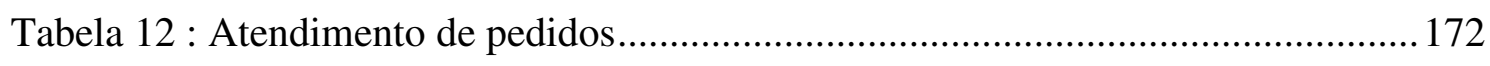

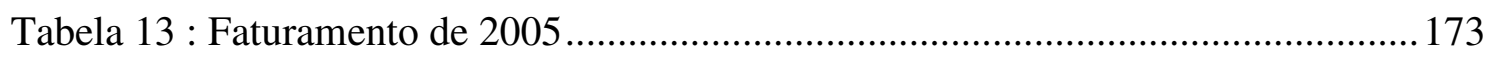

Tabela 14 : Custos mensais da atividade de separação ................................................ 176

Tabela 15 : Custos mensais da atividade de carregamento ......................................... 179 


\section{SUMÁRIO}

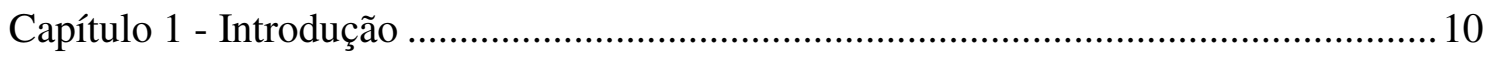

1.1 ESTRUTURA DO TRABALHO ……………………………………………………………………….....

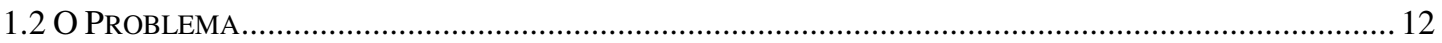

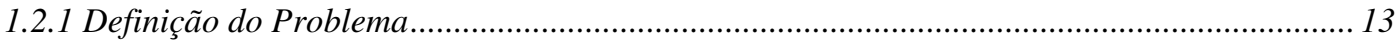

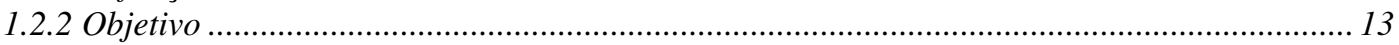

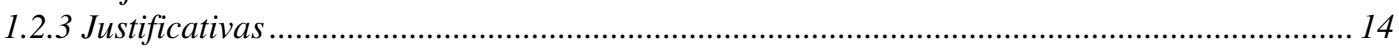

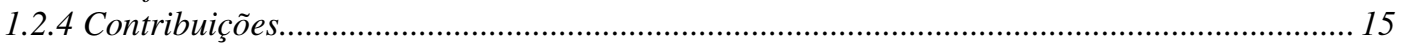

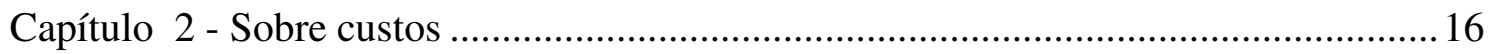

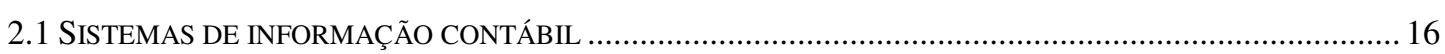

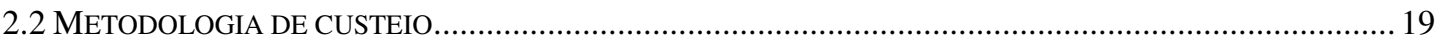

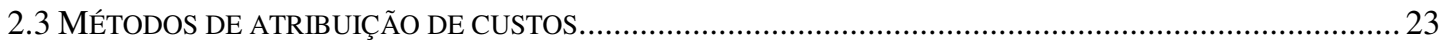

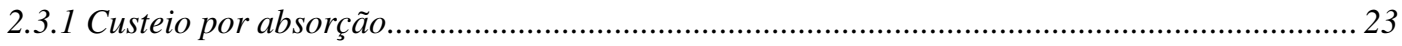

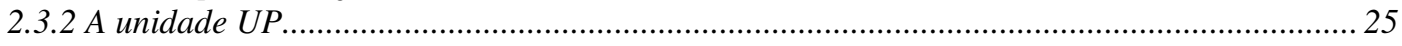

2.3.3 Custeio baseado em atividades (Activity Based Costing) - ABC ........................................... 26

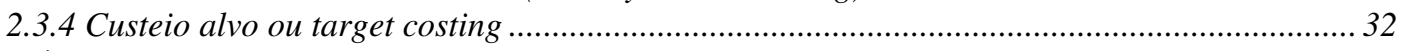

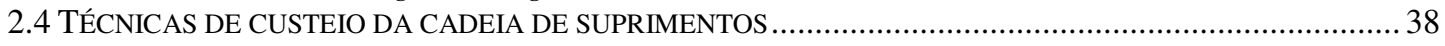

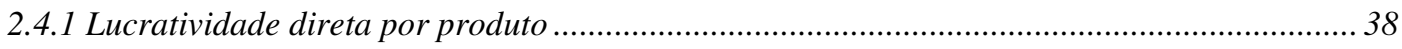

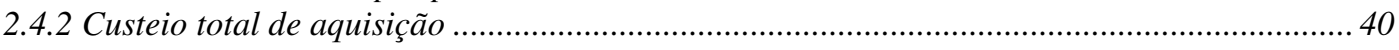

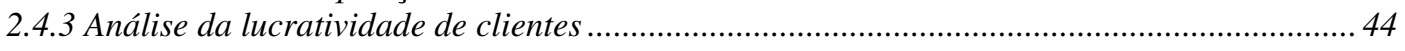

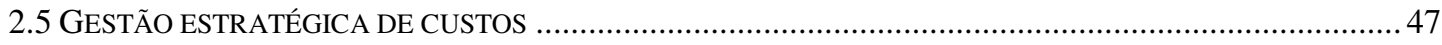

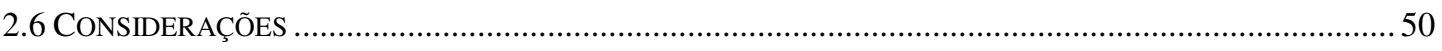

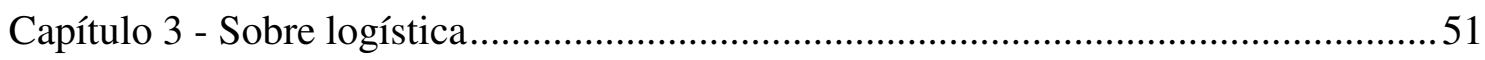

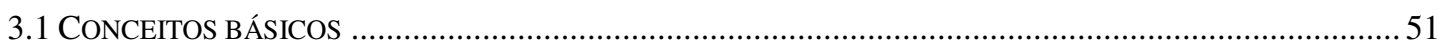

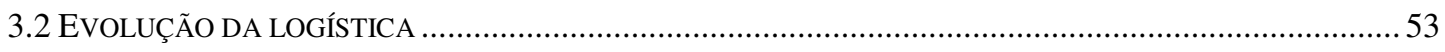

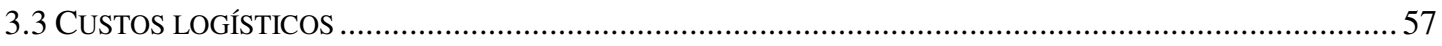

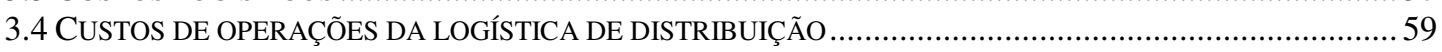

3.4.1 Custos de embalagens e movimentação.............................................................................. 59

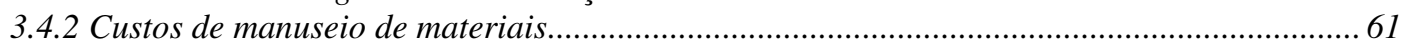

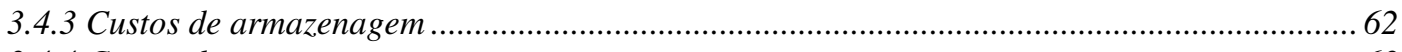

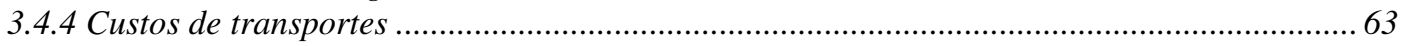

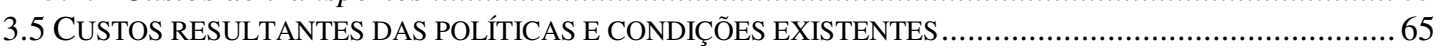

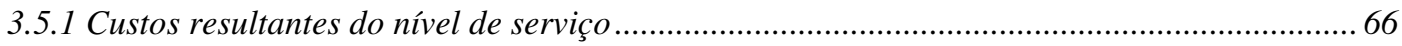

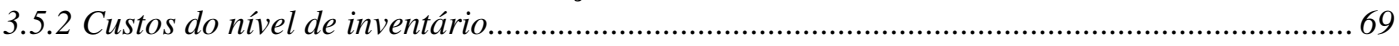

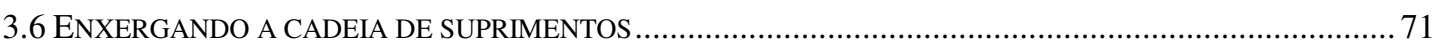

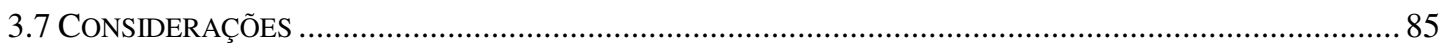

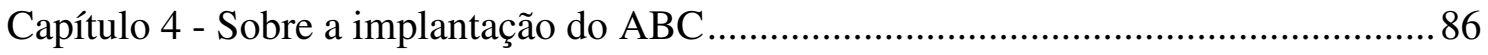

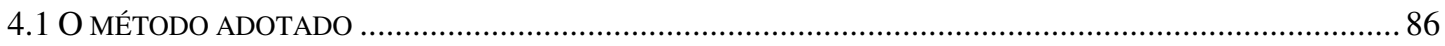

4.1.1 Análise de processos do negócio (BPA - Business Process Analysis) .................................. 88

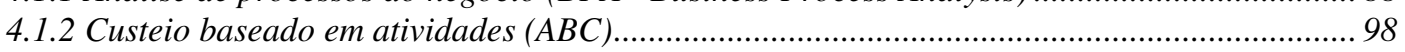

4.1.3 Implementação da Gestão Total dos Custos (TCM - Total Cost Management) ................... 109

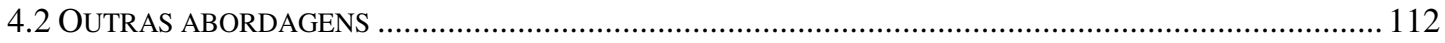

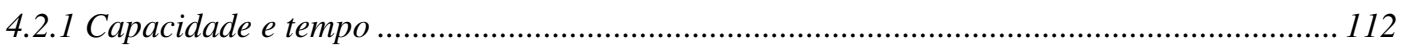

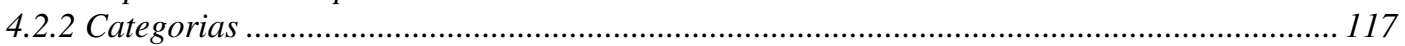

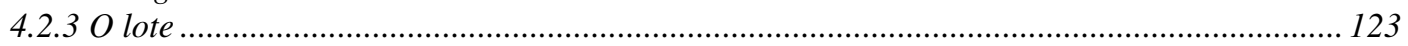

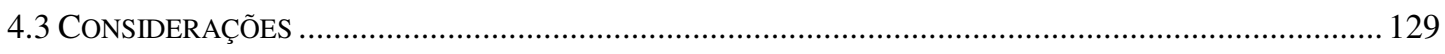

Capítulo 5 - Metodologia de pesquisa.................................................................... 130

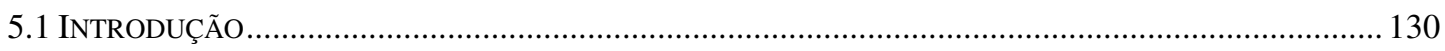

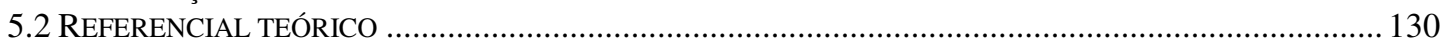




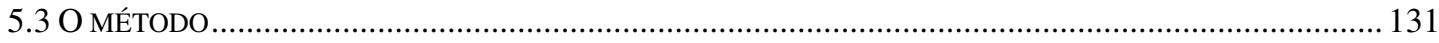

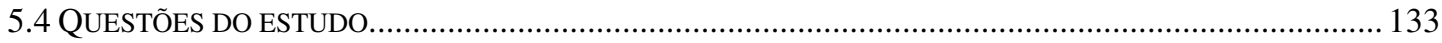

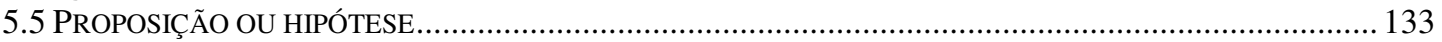

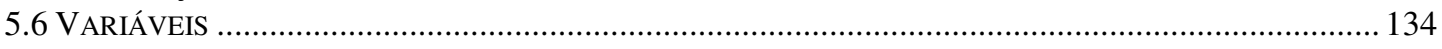

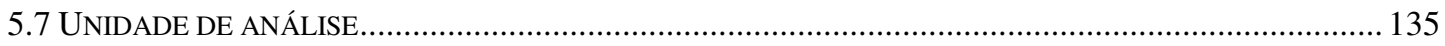

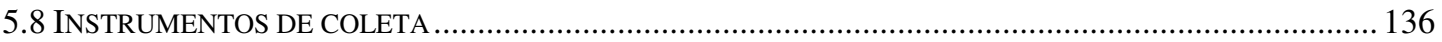

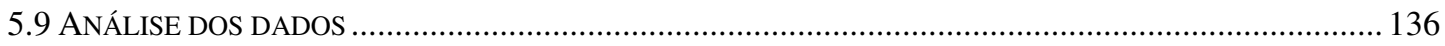

Capítulo 6 - Estudo de Caso..................................................................................... 138

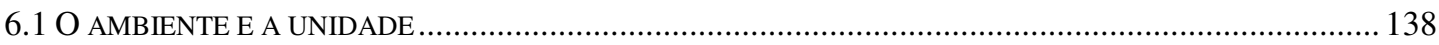

6.1.1 O segmento de transformados plásticos ....................................................................... 138

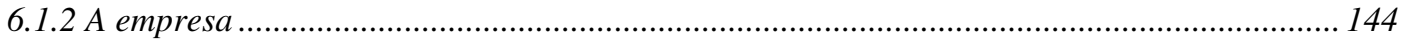

6.1.3 A unidade de Rio Claro .................................................................................................. 147

6.1.4 O centro de distribuição ................................................................................................. 147

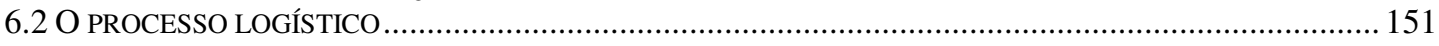

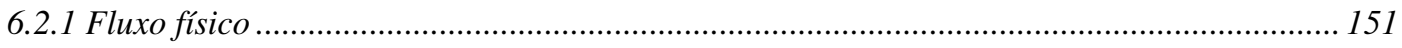

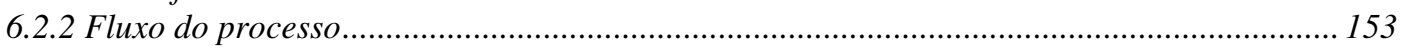

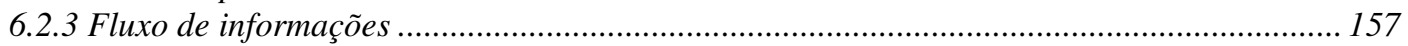

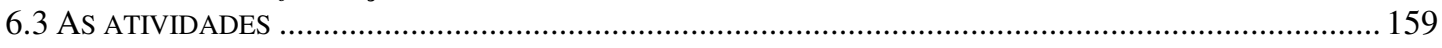

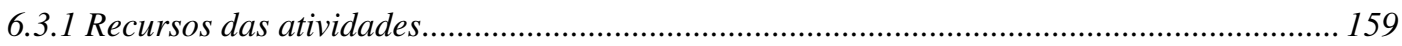

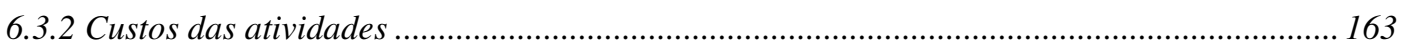

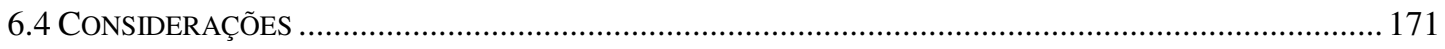

Capítulo 7 - Conclusões ...................................................................................... 184

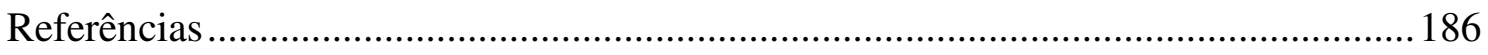

APÊNDICE A - PERGUNTAS PARA ENTREVISTA ........................................................................... 193 


\section{CAPÍTULO 1 - INTRODUÇÃO}

De acordo com Castro (2004), entre 1970 e 2002, a taxa de crescimento anual de valor agregado do setor do transporte excedeu a taxa do setor da agricultura por mais de dois pontos cheios de porcentagem; e da taxa de crescimento do PIB por aproximadamente 1.5 pontos. No mesmo período, o rendimento do transporte da carga, medido em tonelada/quilômetros ou no consumo total de diesel, cresceu em uma taxa anual maior que $6 \%$.

Paralelamente, Faria e Costa (2005) ressaltam a situação problema vivenciada no meio empresarial, cujos métodos tradicionais de contabilidade não reconhecem adequadamente os custos logísticos, dificultando às empresas atingirem custos totais menores por falta de informações adequadas à tomada de decisão em logística.

Para Dornier et al. (2000), até recentemente, muitas empresas focaram sua atenção nas funções de marketing, finanças e produção. Tal atitude é justificada, até certo ponto, pelo fato de que, se uma empresa não é capaz de produzir e vender seus produtos, esta tenderá a eliminação do mercado. Contudo, essa abordagem falha em reconhecer a importância das atividades que devem ocorrer entre pontos e momentos de produção, e pontos e momentos de compra de produtos: as atividades de operações logísticas, que afetam a eficiência e eficácia tanto de marketing quanto de produção, a natureza e os momentos dos fluxos de caixa de uma empresa e, finalmente, a lucratividade da empresa.

A logística é um conceito em constante evolução, atrelado à busca de ganhos de competitividade e níveis de custos reduzidos em função do desafio global e da necessidade de agir de modo rápido frente às alterações ambientais. Até pouco tempo era, essencialmente, associada a transporte e armazenagem, passando a ser combinada, também, com outras atividades, tais como: marketing, suprimentos e atendimento ao 
cliente. Era vista como uma função de apoio, não vital ao sucesso dos negócios. Em uma velocidade impressionante, tal visão vem sendo alterada em direção ao reconhecimento da logística como elemento estratégico.

Neste ambiente, segundo Porter (1989) as empresas têm buscado manter sua competitividade através de dois tipos básicos de vantagem competitiva, por menores custos (liderança por custos) ou por produtos superiores (diferenciação do produto).

O grande desafio das empresas tornou-se conhecer, controlar e reduzir custos. E segundo Shank e Govindarajan (1997, p.5):

[...]a contabilidade existe na administração principalmente para facilitar o desenvolvimento e a implementação da estratégia empresarial. Sob esta visão, a administração de empresas é um processo cíclico contínuo de (1) formular estratégias, (2) comunicar estas estratégias por toda organização, (3) desenvolver e pôr em prática táticas para implementar as estratégias, (4) desenvolver e implementar controles para monitorar as etapas da implementação, e depois celebrar o sucesso no alcance das metas estratégicas. A informação contábil desempenha um papel em cada um dos estágios deste ciclo.

Desse modo, as novas exigências têm gerado um contínuo questionamento às técnicas tradicionais de apuração e gestão de custos. Atendendo a esta demanda, novas técnicas e propostas de abordagem têm sido aprimoradas constantemente, uma delas foi o custeio baseado em atividades - ABC, apontado como uma das principais ferramentas para um sistema de informações de gestão de custos.

Uma vez que o gerenciamento logístico é um conceito orientado para o fluxo, com o objetivo de integrar os recursos ao longo de todo trajeto compreendido entre os fornecedores e clientes finais, é desejável que se tenha uma forma de avaliar os custos e o desempenho desse fluxo.

No intuito de abordar este tema, propõe-se o presente trabalho, cuja estrutura é descrita a seguir.

\subsection{Estrutura do trabalho}

Incluindo este breve prólogo realizado para clarear os objetivos do trabalho, anuncia-se que este será dividido em sete capítulos: 
Capítulo 1 - Introdução, descreve a situação-problema, estabelece o problema central a ser enfocado, delimita-o e anuncia seu principal objetivo. Identifica a importância e relevância deste trabalho. Aponta as justificativas para a realização do estudo proposto, bem como as contribuições dele esperadas.

Capítulo 2 - Sobre custos, realiza uma revisão bibliográfica sobre o tema, abordando alguns métodos de custeio sob o enfoque proposto pelo estudo, com vista à consecução do objetivo estabelecido.

Capítulo 3 - Sobre logística, elucida o assunto demonstrando conceitos e teorias necessárias, discutindo alguns custos envolvidos em processos logísticos e abordando o tema cadeia de suprimentos.

Capítulo 4 - Sobre a implantação do ABC, estabelece a abordagem de implantação do método de custeio baseado em atividades adotadas, bem como apresenta outras com diferentes abordagens.

Capítulo 5 - Metodologia da pesquisa, descreve a metodologia utilizada no desenvolvimento deste trabalho, abordando o referencial teórico do método no que tange ao seu objetivo, delineamento e instrumentos de coleta.

Capítulo 6 - Estudo de caso, estabelece o corpo empírico do trabalho à medida que relata a implantação do método de custeio baseado em atividades num centro de distribuição de uma grande empresa do setor de transformados plásticos.

Capítulo 7 - Conclusões, congrega os resultados obtidos da implantação e infere sobre suas peculiaridades relativas às atividades da logística de distribuição, para realizar o objetivo do trabalho.

\subsection{O Problema}

O inquérito da situação-problema definida na introdução demanda que seja claramente definido o problema trabalho, assim como enunciado o objetivo cuja consecução levará a solução do problema. É tal a utilidade dos próximos tópicos. 


\subsubsection{Definição do Problema}

Christopher (1997) acredita que os tradicionais métodos de contabilidade de custos foram criados para mensurar os custos dos produtos e são inadequados, por exemplo, para auxiliar na análise da rentabilidade por cliente e mercados, o que seria conveniente à atividade logística. Bowersox e Closs (2001) a situação-problema vivenciada no meio empresarial, cujos métodos tradicionais de contabilidade não reconhecem adequadamente os custos logísticos, dificultando, assim, que as empresas atinjam custos totais menores, por falta de informações adequadas para a tomada de decisão em logística.

Apesar de identificadas as vantagens de se utilizar o método de custeio por atividades para produção em ambientes estratégicos que priorizem a diferenciação, pouco existe na literatura sobre o desempenho do custeio baseado em atividades para a logística de distribuição.

A grande diversidade no perfil dos pedidos, em relação à variedade e quantidade de itens, bem como em relação à freqüência das entregas, fazem com que os custos unitários de distribuição sejam diferentes em função do produto e do pedido a ser separado.

Diante desse contexto, enuncia-se o problema central desse trabalho:

Quais as particularidades da aplicação do método de custeio baseado em atividades na logística de distribuição de uma grande empresa do setor de transformados plásticos?

\subsubsection{Objetivo}

O objetivo do estudo está relacionado em como implantar o método (adotado pela Consultoria Ernest \& Young) de custeio baseado em atividades na logística de distribuição. 
Como meta de mensurar o desempenho da utilização do método de custeio baseado em atividades nos custos logístico de distribuição, o presente estudo tem como objetivo:

Aplicar e analisar o custeio baseado em atividades como um método para o levantamento e custeamento das atividades logísticas de distribuição desempenhadas por uma grande empresa do setor de transformados plásticos.

Para atingir este objetivo, foi realizado um estudo de caso a fim de conhecer a realidade das atividades de logística de distribuição de uma empresa do setor de transformados plásticos, além da revisão bibliográfica sobre outros métodos de custeio baseado em atividades.

\subsubsection{Justificativas}

Segundo Dane (1990), para aqueles que conduzem uma pesquisa formal, a necessidade de avaliação é óbvia: ser possível determinar se a pesquisa vale a pena ou não, ainda que seja só como prevenção da perda de tempo. Mas mesmo que nunca tenha-se conduzido alguma pesquisa própria, ainda se faz necessário saber como avaliar a pesquisa de outros. Conduzindo ou não uma pesquisa, todos a usam para ajudar a entender o mundo à sua volta, e, como consumidor de pesquisa precisa-se ser capaz de determinar qual pesquisa é relevante e qual não é. Neste sentido, é condição necessária que uma pesquisa seja importante, viável e original.

Esta pesquisa pode ser considerada importante pois aborda um tema atual e de peso, os custos logísticos. Segundo o Centro de Estudos em Logística (2006) os custos logísticos no Brasil somaram, em 2004, R\$ 222 bilhões ou 12,6\% do PIB nacional. Ainda segundo o referido centro observa-se uma taxa média de crescimento da receita média de prestadoras de serviços logísticos de 338\%, entre 2001 e 2005. Em oposição a uma taxa decrescente de 5,37\% dos custos logísticos no Brasil entre 1996 e 2004.

A pesquisa mostrou-se viável já que cumpriu o cronograma estabelecido, os recursos necessários foram providos e o estudo de caso foi executado à medida que houve permissão por parte da empresa analisada para obtenção de dados, físicos e contábeis.

Ademais, a pesquisa é original pois o assunto vem sendo abordado por estudiosos de outras áreas de conhecimento e profissionais de logística, porém, 
focalizando seus aspectos operacionais, negligenciando as dimensões econômicas da gestão logística.

\subsubsection{Contribuições}

Um trabalho científico pode ser avaliado de acordo com o seu conteúdo e forma, traduzidos, segundo Demo (2001), como qualidade política, no sentido da contribuição científica para preencher lacunas em determinada Ciência, e como qualidade formal, em relação à propriedade lógica tecnicamente instrumentada, dentro de ritos acadêmicos (domínio de técnicas de coleta, manuseio e uso de dados, capacidade de manipular bibliografia, etc.).

A contribuição científica do trabalho reside em explorar um assunto pouco tratado demonstrando, através do estudo de caso, quais as peculiaridades na implantação do método de custeio baseado em atividades na logística de distribuição. Com isso, será possível esclarecer ao público empresarial as situações vantajosas que o custeio baseado em atividades pode ser utilizado e suas limitações, no que tange à logística de distribuição.

Ainda, Demo (2001) declara que a pesquisa é uma atividade de questionamento reconstrutivo, que evita a reprodução e deve ser utilizada como princípio educativo, como parte central para aprendizagem reconstrutiva e para gerar autonomia do sujeito. A pesquisa deve motivar o individuo a saber fazer história própria, ajudá-lo a inserir-se no mercado e, ao mesmo tempo, confrontar-se com ele, para que o bem comum seja referência principal.

Pode-se dizer que outra contribuição desta pesquisa é para o autor, à medida que permite conhecer os assuntos abordados com maior profundidade, através da revisão bibliográfica e do estudo de caso. Permite, outrossim, um primeiro contato com o método científico, possibilitando um grande avanço do autor como pesquisador.

Após esta introdução, inicia-se a revisão sobre os temas necessários à delimitação das idéias contidas no estudo e para se atacar o problema. Serão debatidos conceitos sobre custos, logística e implantação do custeio baseado em atividades. Para definir-se o método utilizado na procura da solução do problema e, em seguida, demonstrar o estudo empírico desenvolvido juntamente com as conclusões. 


\section{CAPÍTULO 2 - SOBRE CUSTOS}

Este capítulo aborda o tema custos, de modo a fornecer diferentes ângulos sobre a questão, à medida que apresenta diferentes métodos de custeio e fornece as bases para o método de custeio utilizado no estudo de caso.

\subsection{Sistemas de informação contábil}

Nesta parte introdutória sobre custos, é necessário esclarecer alguns conceitos envolvidos no estudo de contabilidade de custos e gestão de custos. Uma abordagem sistêmica fornece uma estrutura útil para atingir esse objetivo. Inicia-se com a definição de um sistema de informação contábil.

[...] é aquele que consiste de partes manuais e de computador, interrelacionados, usando processos como coletar, registrar, resumir, analisar e gerenciar dados para fornecer informações aos usuários. Como qualquer sistema, consiste de: objetivos, partes interrelacionadas, processos e saídas. [...] As partes inter-relacionadas incluem a entrada de pedidos e vendas, faturamento de contas a receber e recebimentos de caixa, estoque, razão geral e contabilidade de custos. (HANSEN e MOWEN, 2001, p. 56)

Esquematicamente, conforme Figura 1: 


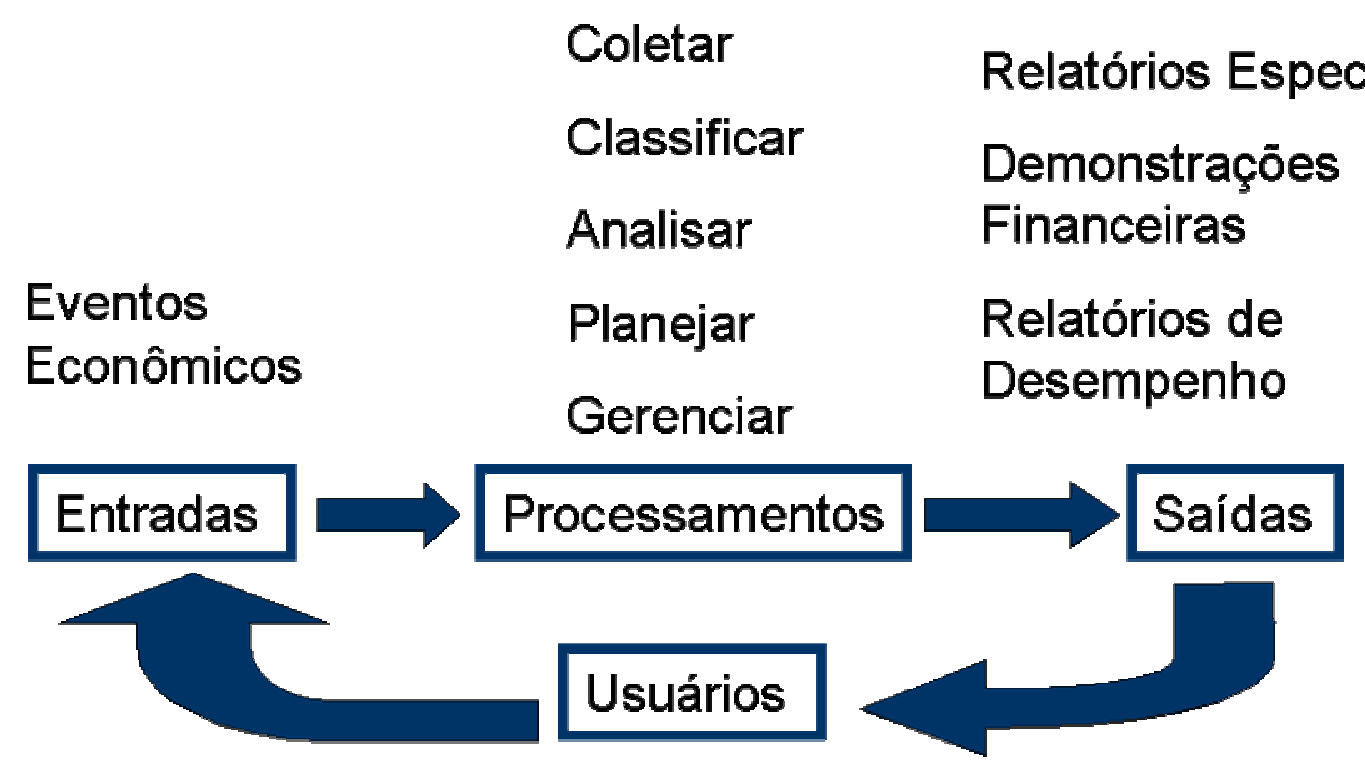

Figura 1: Modelo operacional de um sistema de informações contábeis Fonte: Hansen e Mowen (2001)

Como qualquer outro sistema, este possui entradas que são processadas e que geram saídas para os usuários, no entanto, as entradas, ou seja, os eventos econômicos, são geradas pelos próprios usuários das informações de saída. Este sistema de informações contábeis pode ser dividido em dois subsistemas principais: o sistema de informações de contabilidade financeira e o sistema de informações de gestão de custos.

O primeiro ocupa-se em gerar saídas para usuários externos e seus processos seguem convenções da Comissão de Valores Mobiliários (CVM). Já um sistema de informações de gestão de custos ocupa-se em gerar saídas para usuários internos e seus processos não são regidos por qualquer critério formal.

O sistema de informações de gestão de custos tem como objetivo primeiro fornecer informações de custo sobre serviços, produtos ou outros objetos; por exemplo, pode-se desejar saber o custo de um produto ou de um canal de distribuição. Também pode fornecer informações para tomada de decisões, tais como, comprar ou produzir uma determinada peça, ainda para planejamento e controle, por exemplo, como informações sobre custos e receitas esperados para um novo produto podem afetar seu projeto e estratégia de marketing.

Um sistema de informações de gestão de custos se divide em dois principais subsistemas: o sistema de informações de contabilidade de custos e o sistema de informações de controle operacional. O primeiro é projetado para atribuir custos aos produtos individuais, serviços e outros objetos de custo, como especificado pela gestão. Segundo Hansen e Mowen (2001, p.61) um objeto de custo é “[...] qualquer item, como 
produtos, clientes, departamentos, processos, atividades, e assim por diante, para o qual os custos são medidos e atribuídos".

O sistema de informações de controle operacional se ocupa em avaliar quais atividades devem ser desempenhadas e avaliá-las, para identificar possibilidades de melhoria e meios de atingi-las. A Figura 2 demonstra, esquematicamente, como um sistema de informações contábeis pode ser dividido.

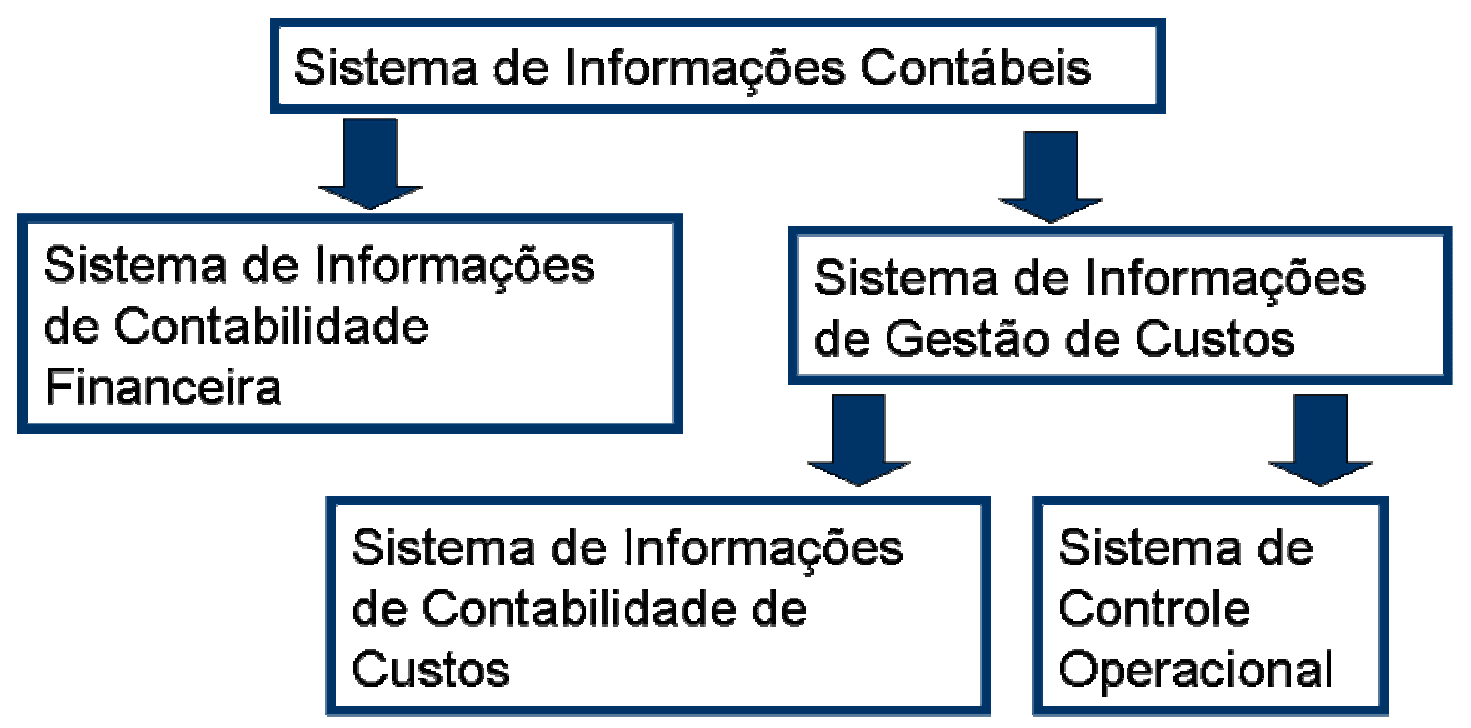

Figura 2: Os subsistemas do sistema de informações contábeis Fonte: Hansen e Mowen (2001)

Para reduzir o armazenamento e uso redundante de dados num sistema de informações de gestão de custos é necessária uma integração com outros sistemas de uma empresa. Desta maneira, as informações de custo beneficiam a organização como um todo. Por exemplo, um gestor da área de projetos pode necessitar de informações precisas e confiáveis de custos de produção, marketing e serviços ao cliente. A Figura 3 demonstra que o sistema de informações de gestão de custos recebe informações de outros sistemas e também fornece informações para estes sistemas. 


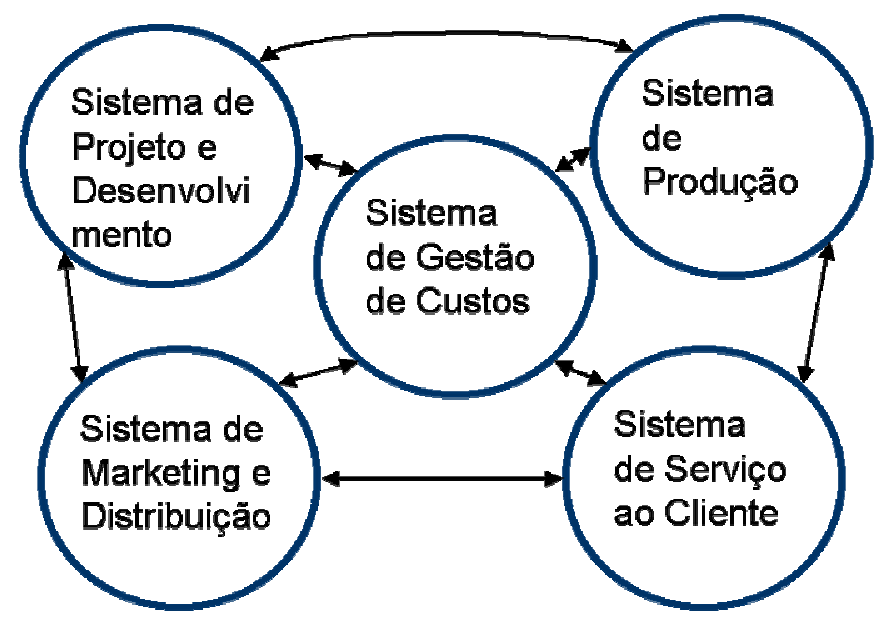

Figura 3: Um sistema de gestão de custos integrado Fonte: Hansen e Mowen (2001)

Para que estes sistemas se comuniquem de maneira coerente, devem se expressar numa mesma linguagem, em códigos pré-estabelecidos, que possam ser interpretados de maneira a garantir que a informação original seja entendida. Desse modo, faz-se necessário definir um método de custeio comum a ser seguido pela empresa.

\subsection{Metodologia de custeio}

Segundo Novaes e Alvarenga (2000) um dos sete tipos de conhecimentos básicos ou de técnicas quantitativas necessárias ao bom desempenho do profissional de logística é a noção sobre custos. Estes são a soma dos insumos (mão-de-obra, energia, materiais diversos, equipamentos, instalações fixas, etc.) necessários para realizar um serviço ou operação, avaliados monetariamente.

Vale a pena destacar que custos são diferentes de despesas e de gastos. Martins (1998) define gastos como qualquer sacrifício financeiro efetuado para obtenção e venda de um bem (produto) ou serviço.

Só existe gasto no ato da passagem para a propriedade da empresa do bem ou serviço, ou seja, no momento em que existe o reconhecimento contábil da dívida assumida ou da redução do ativo dado em pagamento. (MARTINS, 1998, p. 61).

Tais gastos, para efeitos da contabilidade de custos, podem ser separados em custos e despesas.

Para o Instituto Brasileiro de Contadores - IBRACON - (1995) custo 
[...] é o preço pelo qual se obtém um bem, direito ou serviço. Por extensão, é também o montante do preço da matéria-prima, mão-deobra e outros encargos incorridos para a produção de bens e serviços. Ele é, pois, tanto o preço pelo qual é adquirido um bem ou serviço, como o incorrido no processo interno da empresa para prestação de serviços ou obtenção de bens, venda ou uso interno. E despesa é o encargo necessário para comercializar os bens ou serviços objetos da atividade, bem como para a manutenção da estrutura empresarial independente da sua frequiência. A despesa, embora direta ou indiretamente necessária para a geração da receita, não está associada à prestação do serviço ou à produção do bem, não sendo, pois, agregada ao custo.

Martins (1998) declara que custo é um gasto que, armazenado na forma de investimento (gasto ativado em função de sua vida útil ou de benefícios atribuíveis a período(s) futuro(s)), como por exemplo, a matéria-prima comprada passa a ser utilizada como fator de produção (bem ou serviço) para a fabricação de um produto ou execução de um serviço. No momento da sua utilização na fabricação do bem, surge o custo da matéria-prima como parte integrante do bem elaborado.

Abaixo demonstram-se algumas classificações de custo:

Custos diretos e indiretos - Alguns tipos de insumos podem ser diretamente alocados às atividades produtivas (mão-de-obra, material para embalagem de produtos, etc.) outros estão relacionados com a empresa num todo, comuns a diversos setores produtivos (aluguel, energia elétrica, etc.). Os custos que permitem uma fácil alocação são chamados de custos diretos, aqueles em que a alocação é estimada, ou arbitrária e subjetiva são chamados de custos indiretos.

Custos fixos e custos variáveis - Quando se produzem bens ou serviços, certos custos vão variar diretamente com uma variável explicativa, - como por exemplo, a quantidade produzida, - estes custos são chamados de custos variáveis. Os custos fixos derivam do emprego de recursos fixos e não dependem de uma variável, tais custos incorrem mesmo que a empresa não produza nada. Para Martins (1998) os custos fixos devem ser considerados para a existência do negócio, enquanto custos variáveis são custos para gerar negócios. Por exemplo, numa carga transportada por um caminhão, o custo do combustível e as despesas com pneus variam diretamente em função da quilometragem, logo, são custos variáveis. O custo de oportunidade de capital e o seguro do veículo, por outro lado, não variam de acordo a quilometragem, assim são custos fixos. 
Custo marginal - É o valor acrescido ao custo de um produto, para se produzir uma unidade a mais, ou seja, representa o valor diferencial entre uma unidade qualquer produzida e uma anterior.

A divisão dos custos permite formar um sistema de informações de gestão de custo no intuito de saber onde e como estão sendo gastos os recursos, permitindo gerenciá-los. Existem vários métodos de atribuição de custos, o mais comum entre eles é o custeio por absorção, desenvolvido no início do século passado. Segundo Martins (1998) os métodos de atribuição de custos são utilizados para: avaliação de estoques, tomada de decisões e controle.

Para que as empresas pudessem comparar dados em diferentes datas, ou mesmo comparar dados de outras empresas, houve a necessidade de se criar alguns princípios básicos de contabilidade, os princípios de contabilidade geralmente aceitos (PCGA):

a) Princípio da realização da receita

O reconhecimento contábil do resultado (lucro ou prejuízo) só pode ser feito quando da realização da receita. Esta ocorre quando da transferência do bem ou do serviço para terceiros. Assim a contabilidade de custos não pode apurar resultado antes desse instante e, no máximo, pode servir como ferramenta para previsão de lucro.

b) Princípio da competência ou da confrontação entre despesas e receitas

Toda despesa diretamente delineável com as receitas reconhecidas em determinado período, com as mesmas deverá ser confrontada. Os consumos ou sacrifícios de ativos (atuais e futuros), realizados em determinado período e que não puderam ser associados ao período nem às dos períodos futuros, deverão ser descarregadas como despesas do período em que ocorreram.

c) Princípio do custo histórico como base de valor

[...] O custo de aquisição de um ativo ou dos insumos necessários para fabricá-lo e coloca-lo em condição de gerar benefícios para a empresa representa a base de valor para a Contabilidade, expresso em 
termos de moeda de poder aquisitivo constante [...] (IBRACON, 1995, p.30).

Disso concluí-se que os ativos são registrados contabilmente por seu valor de entrada original, ou seja, histórico.

d) Consistência ou uniformidade

Se existem diversas alternativas para o registro contábil de um mesmo evento, todas válidas dentro dos princípios geralmente aceitos, deve a empresa adotar uma delas de forma consistente. Ou seja, uma vez adotado uma forma para se registrar um evento, esta deverá sempre ser mantida. Quando houver interesse ou necessidade de mudar o procedimento, deve a empresa reportar o fato e o valor da diferença em relação ao que será obtido se não houvesse a quebra de consistência.

e) Conservadorismo ou prudência

Se o contador se achar em dúvida ao tratar um determinado gasto como ativo ou redução de patrimônio líquido, ele deve optar pela forma de maior precaução, ou seja, pela redução de patrimônio líquido. Levando-se em conta os custos de produção, se a dúvida estiver em considerar um gasto como custo ou despesa, deve prevalecer a hipótese mais pessimista que não vá provocar o estoque desse valor, e sim sua transformação imediata em despesa.

f) Materialidade ou relevância

O Contador deverá, sempre, avaliar a influência e materialidade da informação evidenciada ou negada para o usuário à luz da relação custo-benefício, levando em conta aspectos internos do sistema contábil [...] (IBRACON, 1995)

Alguns pequenos materiais de consumo industrial podem, por terem valores irrisórios, ser englobados e considerados como custo no período de sua aquisição, simplificando o procedimento por se evitar seu controle e baixa por diversos períodos.

Depois de definidas as regras comuns que delimitam o método de custeio pode-se partir para atribuição dos custos aos objetos de custeio. Serão abordados os métodos de custeio por absorção, por unidade de esforço de produção, por atividades e custeio alvo de modo a registrar uma visão ampla sobre os diferentes métodos. 


\subsection{Métodos de atribuição de custos}

\subsubsection{Custeio por absorção}

Para Martins (1998) o sistema de custeio por absorção é derivado da aplicação dos princípios de contabilidade geralmente aceitos ao processo de apropriação dos gastos da empresa aos produtos manufaturados por ela. Os critérios normalmente utilizados são volume produzido e/ou horas máquinas, lembrando que apenas os gastos relacionados à produção são alocados aos produtos; outros gastos são considerados despesas do período, tais como recursos aplicados a vendas ou distribuição.

Alguns passos devem ser seguidos para aplicação deste método de custeio:

1. analisar os gastos e separá-los entre custos e despesas;

2. distribuir os custos diretos aos produtos;

3. alocar os custos indiretos aos produtos, baseando-se em algum critério de rateio.

Como a maioria das empresas apresenta uma configuração organizacional departamentalizada, o processo acima descrito melhor especificado seria:

1. separar gastos entre custos e despesas;

2. separar custos diretos e indiretos;

3. apropriar os custos diretos aos produtos;

4. separar custos indiretos entre específicos e comuns, e alocar os específicos aos respectivos centros de custo;

5. ratear os custos indiretos comuns e dos da administração geral da produção aos diversos centros de custo;

6. alocar os custos indiretos, que agora só estão nos centros de custo produtivos, aos produtos segundo critérios fixados.

Esquematicamente, conforme Figura 4: 


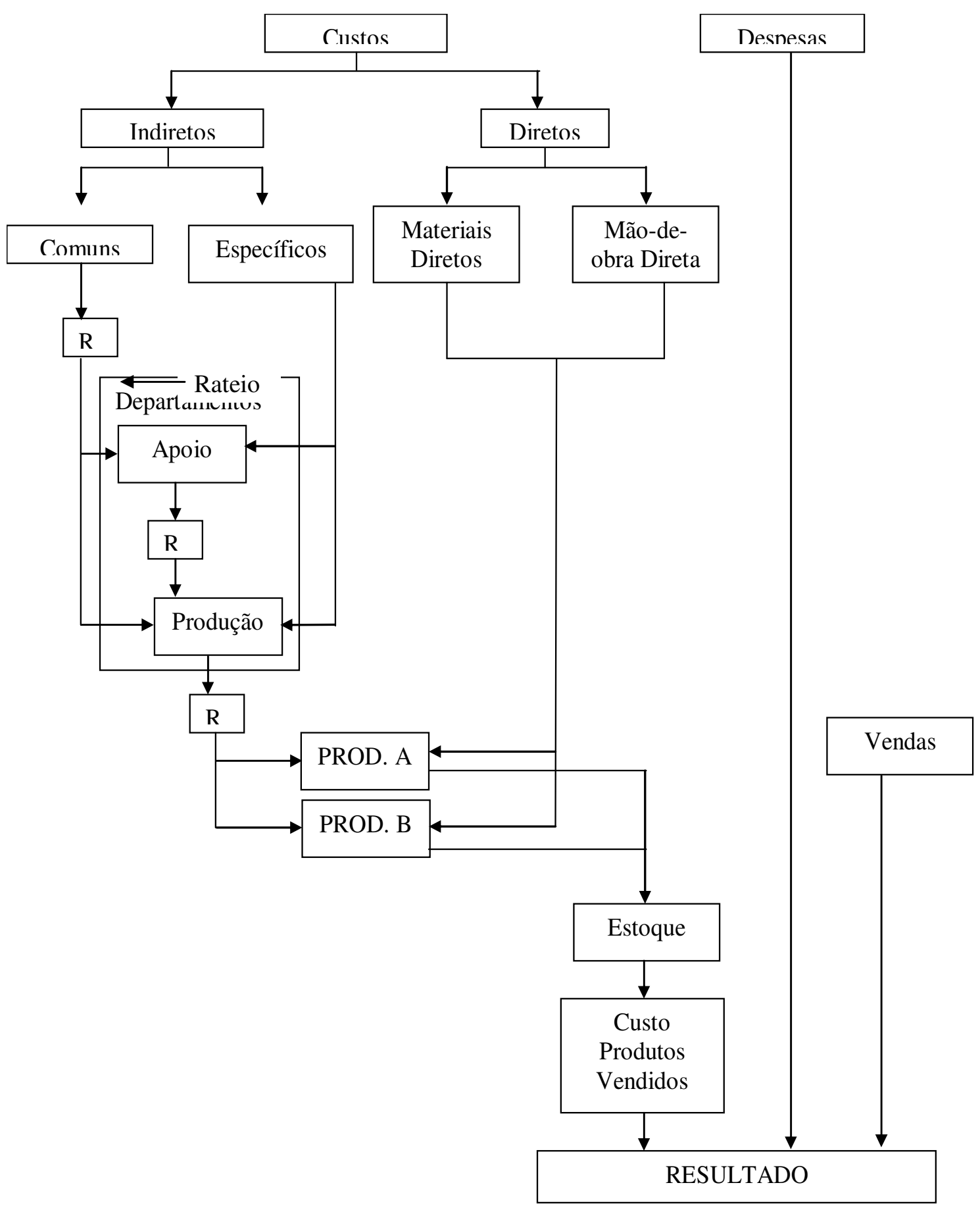

Figura 4: Custeio por absorção Fonte: Martins (1998)

Apesar de mais utilizado, o método de custeio por absorção não reina único na contabilidade. Outros foram criados utilizando diferentes métodos de alocação de recursos e, com isso, utilizando características intrínsecas ao ambiente custeado. Adiante, abordam-se alguns destes. 


\subsubsection{A unidade UP}

Foi desenvolvida pelo aperfeiçoamento da unidade GP, denominada assim pelo seu criador, Georges Perrin. Durante a segunda guerra, o engenheiro francês se dedicou ao estudo para medir uma produção diversificada. Ao fim da guerra e com sua volta às atividades profissionais, ele apresentou sua unidade única de medida de produção industrial.

Após sua morte em 1952, o Bureau Perrin continuou suas atividades, e os estudos de Perrin foram reunidos, possibilitando a publicação de um livro sobre esta unidade. A publicação contou com a colaboração do italiano Franz Allora que se mudou para o Brasil após a segunda guerra. Durante muitos anos Allora usou a técnica e veio desenvolvê-la, criando assim um novo conceito capaz de controlar a produção de uma empresa.

Esta unidade ficou conhecida como UP - unidade de produção ou UEP - unidade de esforço de produção. Nela está inclusa a idéia de que a matéria-prima transforma-se em produto acabado, após receber uma determinada quantidade de esforços de produção/transformação. Cada setor, área ou mesmo equipamento, que posteriormente serão denominados postos operativos (PO’s), contribui com um determinado esforço para a transformação dessa matéria-prima. Em função do tempo que essa matéria-prima permanece no $\mathrm{PO}$, ela receberá uma quantidade maior ou menor de esforço, que serão as UP's.

Para produzir-se determinado produto serão necessárias $n$ unidades UP, que são a soma dos esforços em cada PO. Então os custos de um produto serão subdividos em:

- matéria prima processada;

- custos de transformação: mão-de-obra direta, mão-de-obra indireta, depreciação, materiais de consumo, peças de manutenção, energia elétrica, manutenção e utilidades.

Para se aplicar o método, deve-se determinar o nível de atividade da empresa, pela soma das UP's produzidas, e, assim, determinar os custos de transformação de cada produto. Isto está baseado em três princípios básicos:

I. Constância das relações 


\section{Estratificações \\ III. Valor agregado (rotações)}

A constância das relações preconiza que, independentemente das variações de preços unitários, os esforços de produção desenvolvidos pelas operações elementares de trabalho numa fábrica, são interligados pelas relações constantes no tempo. Pelo princípio da estratificação, o grau de exatidão dos resultados fica essencialmente dependente do grau de diferenciação de cada nova estratificação de despesas em relação às precedentes.

Para esclarecer o princípio do valor agregado leva-se em conta que o lucro é a parcela de dinheiro a mais que a empresa obtém, vendendo o seu trabalho, ou seja, a soma dos esforços de produção despendidos para transformar as matérias-primas em produtos acabados.

Neste método pode-se inferir que o ponto de conexão, base comum para o custeio, é o tempo de transformação de cada unidade processada. Não mais se utiliza o volume como medida única para alocação dos recursos. Isto também pode ser verificado no custeio baseado em atividades, ou seja, não se utiliza apenas o volume como base para alocação, como se explica a seguir.

\subsubsection{Custeio baseado em atividades (Activity Based Costing) - ABC}

O conceito ABC surgiu nos Estados Unidos, na década de 1980, e foi formalizado pelos professores Robert Kaplan e Robin Cooper, na Harvard Business School, com o objetivo principal de aprimorar a alocação dos gastos aos produtos. Porém a origem do método data da década de 1960, segundo Robles (1996).

$\mathrm{O}$ autor atesta que o $\mathrm{ABC}$ teve origem nos estudos de Armand Feingebaum (1957) e de Joseph Duran (1960), que definia as categorias de custos relacionados com a qualidade, separados em custos de prevenção, avaliação e falhas.

Uma das primeiras publicações da terminologia ligando atividades e custo é normalmente atribuída a George J. Staubus, que em 1971 publicou um artigo intitulado “Activity Costing and Input-Output Accounting". Em 1985, Jeffrey Miller e Thomas Vollmann escreveram o artigo "The Hidden Factory", no qual destacaram as distorções provocadas pelo tratamento convencional dispensado aos custos indiretos. Concluem 
que a maior parte desses custos estão associados às transações e não aos produtos. Segundo Miller e Vollmann (1985, p.3):

As unidades de produtos determinam a mão-de-obra direta e os insumos materiais no chão de fábrica real. Mas na fábrica oculta, onde se acumula o grosso dos custos indiretos de fabricação, a verdadeira força motriz provém de transações e não de produtos físicos.

Depois dos anos de 1980, o custeio baseado em atividades começou a ser amplamente desenvolvido por intermédio de empresas de consultoria (Bain \& Co. e a Boston Consulting Group) e pela implementação de sistemas em empresas como a Union Pacific, Caterpillar, Hewlett-Packard e outras que se tornaram tema de estudos de casos da Harvard Business School.

Martins (1998) diz que a busca por qualidade gerou a demanda por medidas diferentes das usuais, como o custo da qualidade e da não qualidade. A mudança no processo produtivo acarretou diminuição dos estoques, expondo a inadequação dos sistemas tradicionais de custeio e mostrou quão irrelevante é a ênfase na valoração de estoques. Com o advento das máquinas automatizadas, houve uma mudança nas proporções e características dos custos industriais, aumentando os custos indiretos de fabricação e diminuindo a mão-de-obra-direta, principais pontos para o rateio no sistema de custos tradicional.

Nesse sentido, visando discutir e trocar informações entre empresas industriais, empresas de consultoria, órgãos governamentais e universidades, criou-se em 1986 um fórum internacional, organizado pela CAM-I (Computer Aided Manufacturing International, Inc.) para se desenvolver um sistema de gerenciamento de custos (Cost Management System / CMS), também conhecido como gestão estratégica de custos (Strategic Cost Management / SCM). O CMS tem como base a gestão baseada em atividades (Activity Based Management / $A B M$ ), que dá ênfase às decisões tomadas com base nas atividades desenvolvidas pela empresa, sendo estas últimas as consumidoras de recursos e não os produtos. Como ferramenta do ABM, o custeio baseado em atividades faz alocações de custos baseando-se nos geradores de custos, as atividades.

De acordo com o IBRACON (1995, p. 17)

[...] uma empresa é um conjunto de atividades, cada uma composta por tarefas, que transformam os recursos internos, sejam eles mão-deobra ou outros custos e despesas, em produtos que teoricamente deveriam agregar valor ao negócio. 
Para Martins (1998, p. 100)

[...]uma atividade é uma combinação de recursos humanos, materiais, tecnológicos e financeiros para se produzirem bens ou serviços. É composta por um conjunto de tarefas necessárias ao seu desempenho. As atividades são necessárias para concretização de um processo, que é uma cadeia de atividades correlatas, inter-relacionadas.

Segundo Gonçalves (1998) as atividades são unidades de trabalho que identificam, com um nível de detalhamento adequado, como a empresa emprega o tempo e os recursos disponíveis.

Para Brimson (1996, p. 63) as atividades constituem o fundamento deste sistema de gerenciamento de custos (ABC). Uma atividade descreve como uma empresa emprega seu tempo e seus recursos para alcançar os objetivos empresariais. Atividades são processos que consomem recursos substanciais para gerar uma produção e que têm como principal função converter recurso em produção.

Esta abordagem funcional permite identificar funções homogêneas, a partir da decomposição de uma função em processos, destes em atividades, as quais podem ser decompostas em tarefas, conforme Figura 5.

\section{Processo}

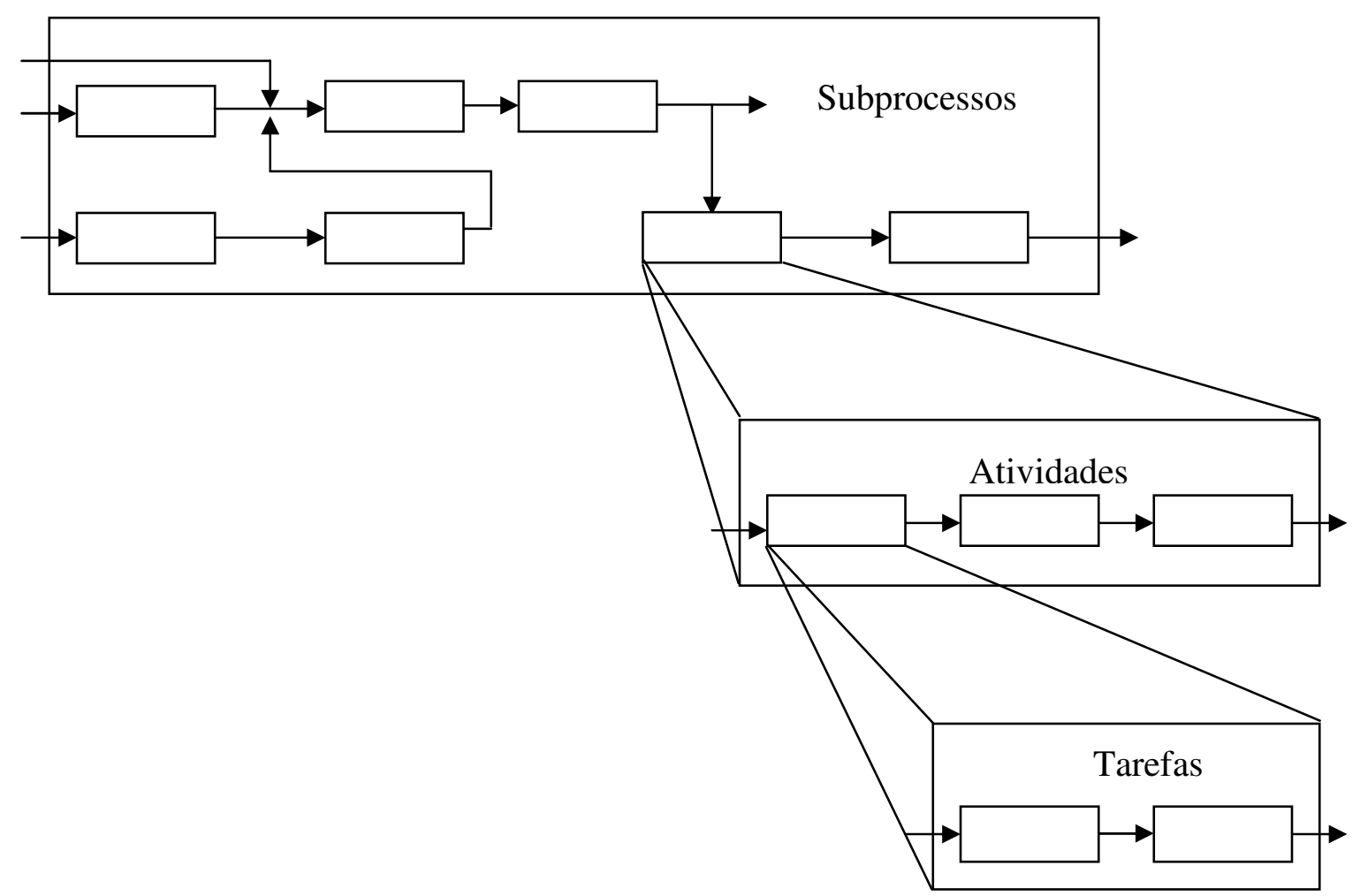

Figura 5: Hierarquia do processo.

Fonte: Harrington (1993., p.34) 
Para Cooper e Kaplan (1998) as atividades podem ser agrupadas em processos de negócio e, hierarquizadas em nível de unidade, lote e produto, cliente e instalação. Atividades em nível de unidade devem ser executadas para cada produto ou serviço gerado e variam proporcionalmente aos volumes de vendas e produção. Em nível de lote, as atividades devem ser executadas por lote ou preparação executada, e são independentes do número de unidades do lote.

Atividades associadas a produtos/serviços e clientes específicos são consideradas de suporte, e independem do volume de produção, vendas e das quantidades de lotes de produção e pedidos de clientes.

Enquanto pelo método tradicional de alocação os critérios são limitados, no $\mathrm{ABC}$ existe uma multiplicidade de critérios, denominados direcionadores de custos, cada qual específico à atividade com que se relaciona. Independente de sua aplicação conjunta ou não a outros métodos de custeio, o ABC permite que a estrutura genérica de custos de uma empresa passe por um nível de detalhamento e aprimoramento muito maior.

De acordo com Martins (1998), a implantação de um projeto ABC pode ser feita em cinco etapas:

1. Identificação das atividades relevantes;

2. Atribuição de custos às atividades;

3. Identificação e seleção dos direcionadores de custos;

4. Atribuição de custos às atividades do modelo;

5. Atribuição dos custos das atividades aos produtos (objetos).

Segundo Hansen e Mowen (2001) as atividades são o foco do custeio baseado em atividade. Logo, identificá-las é a primeira etapa lógica no projeto de um sistema de custeio baseado em atividades. Identificar uma atividade é o equivalente a descrever a ação empreendida. Quando se tem uma lista de atividades, seus atributos são usados para defini-las. Atributos de atividades incluem as tarefas que descrevem as atividades, os tipos de recursos consumidos, o total de tempo gasto em cada atividade, os objetos de custo que consomem a atividade e um direcionador de atividade.

Os atributos definem as atividades e, ao mesmo tempo, se tornam a base para a classificação das atividades. Isso permite uma clara divisão entre atividades que 
adicionam valor e que não adicionam valor. No projeto de um sistema de custeio baseado em atividades, os atributos desejados e as classificações essenciais precisam ser caracterizadas de antemão, para que os dados necessários possam servir de base para criar um dicionário de atividades. Este pode ser criado com ajuda de entrevistas, questionários, pesquisas e observação, para identificação das atividades e atributos necessários para o custeio.

Depois que as atividades foram identificadas e descritas, o próximo passo é determinar quanto custa para realizar cada atividade. Para isso deve-se identificar os recursos que estão sendo consumidos em cada atividade. Seus custos são encontrados no razão geral, porém quanto é consumido em cada atividade não é revelado. Assim, torna-se necessário atribuir os custos dos recursos às atividades usando alguns dos seguintes métodos, citados por ordem de importância: o rastreamento direto, por direcionador e em ultimo caso a alocação (baseada em volume, por exemplo).

O rastreamento direto é possível quando existe uma identificação clara, direta e objetiva de certos itens e custos com certas atividades, podendo ocorrer com salários, viagens, depreciação, material de consumo, etc. Já o rastreamento por direcionador é uma alocação com base na identificação da relação de causa e efeito entre a ocorrência da atividade e a geração dos custos, sendo expressa pelos direcionadores de custos de recursos, como, por exemplo, número de empregados, área ocupada, tempo de mão-deobra, quantidade de kWh, tempo de máquina, etc.

Pode-se dividir os direcionadores em três grupos:

- direcionadores de custo, como evento causal que influencia a quantidade de trabalho, e portanto os custos, em uma atividade,

- direcionadores de recursos, que são fatores que mensuram o consumo dos recursos pelas atividades. Para se coletar dados sobre direcionadores de recursos pode-se utilizar sistemas de controle de tempo, questionários, entrevistas ou formulários de pesquisa, e

- direcionadores de atividades, que medem as demandas que os objetos de custo colocam nas atividades.

Para Martins (1998) como as atividades exigem recursos para ser realizadas, pode-se inferir que o direcionador representa a verdadeira causa dos custos. Portanto o 
direcionador de custos deve refletir a causa básica da atividade e, por conseqüencia, da existência de seus custos.

Continuando os passos para implementação do custeio baseado em atividades, na etapa seguinte deve-se classificar as atividades em primárias e secundárias (de apoio e primárias). Se existirem atividades secundárias, então existem estágios intermediários. Num estágio intermediário, o custo das atividades secundárias é atribuído àquelas atividades (ou outros objetos de custo intermediários) que consomem seus resultados. É necessária extrema cautela na realização deste procedimento, pois a utilização irrestrita deste tipo de alocação de custos pode vir a causar grandes distorções, como as ocorridas nos rateios de departamentalização, onde os custos dos departamentos de apoio são totalmente rateados para os departamentos de produção, marketing, etc.

Uma vez identificadas as atividades relevantes, seus direcionadores de recursos e respectivos custos, o próximo passo é custear os objetos (produtos, canais de distribuição, etc.). Para tanto, faz-se necessário o levantamento da qualidade e da quantidade de ocorrência dos direcionadores de atividades por período e por objeto. Os direcionadores que foram escolhidos para levar o custo das atividades para os objetos demonstram a relação entre atividade e objeto. $\mathrm{O}$ custo total de manufatura do produto ou o custo total para atender um cliente será a soma do custo de cada atividade mais o custo da matéria-prima consumida. Para cada produto ou cliente, deve existir um controle que contenha todas as atividades que são realizadas para sua execução.

Ostrenga et al. (1993) em seu Guia da Ernst \& Young para Gestão Total de Custos, em resumo dizem que o custeio baseado em atividades ocorre em duas fases, na primeira são determinados os custos das atividades importantes e, na segunda, alocamse os custos das atividades aos produtos ou a outros objetos de interesse.

Depois de identificadas as atividades, inicia-se a reorganização da classificação de custos, das categorias do livro razão geral para as categorias de atividades, através de um exame global da atual estrutura da contabilidade e do desenvolvimento de uma arquitetura do fluxo de custos do ABC. Em seguida, através do exame dos custos de centros de custos individuais, deve-se especificar as regras para a alocação de custos às atividades (rastreamento direto, por direcionador ou alocação). Caso não seja possível a alocação direta, deve-se definir os direcionadores ou geradores de custos. Estes servem como base para alocar custos, a partir da sua orientação do razão geral, às atividades (ou grupos de custo de atividades). 
No próximo passo, deve-se colher informações de cada direcionador se, o número de empregados for escolhido como um direcionador de uma atividade, deve-se contar o número de pessoas utilizadas em cada atividade. Assim, pode-se calcular um direcionador de recurso ou índice de custeio para cada categoria de custos. Depois de formados os grupos de custos de atividades especificam-se os direcionadores de atividades, que servem para alocação de custos dos grupos de custos de atividades para os objetos de custos.

Finalmente, deve-se coletar ou desenvolver dados a respeito de cada direcionador de atividades (gerador) para cada objeto, multiplicar os direcionadores de atividades pelos direcionadores de recurso e somar o custo das atividades consumidas para cada objeto de custo. O uso do custeio baseado em atividades é apropriado para compreender o que causa custos em uma empresa e para avaliar a lucratividade relativa de serviços, processos, produtos, clientes e outros objetos, bem como, para determinar as áreas mais necessitadas de melhorias na empresa.

Porém, para usar o custeio baseado em atividades no intuito de mudar os produtos e serviços oferecidos com a intenção de reduzir custos indiretos globais, faz-se necessário desenvolver um plano associado para garantir que as reduções na demanda por atividades indiretas realmente ocorram e que os recursos atualmente usados para prover tais atividades sejam redistribuídos. Sem esta idéia é pouco provável que as ações tomadas em resposta às descobertas do $\mathrm{ABC}$ tenham efeito positivo sobre a lucratividade.

Lucratividade, essa palavra retumbante em tantas reuniões executivas é o ponto de análise inicial do próximo método de custeio, o custeio alvo.

\subsubsection{Custeio alvo ou target costing}

O target costing foi criado pelos japoneses nos anos de 1960, baseado na idéia americana de engenharia de valor. Essa técnica foi desenvolvida por engenheiros da General Electric - GE, durante a segunda guerra mundial. O trabalho voltava-se, sobretudo, para a pesquisa de novos materiais, com custos mais baixos e grande disponibilidade, que pudessem substituir outros mais raros e de custo mais elevado, durante os anos de guerra. Terminada a guerra, quando os materiais voltaram a ser acessíveis, percebeu-se, porém, que as alterações criaram economias sem prejudicar o nível de satisfação do consumidor e, em algumas situações, esse nível até melhorou. Os 
executivos da GE, analisando o sucesso da aplicação da engenharia de valor na substituição de materiais, propuseram sistematizar essa técnica e desenvolver um método.

Os japoneses, derrotados na segunda grande guerra, adotaram várias técnicas ocidentais, entre elas, a engenharia de valor. Entretanto acreditavam que era muito mais vantajosa a combinação de profissionais de planejamento, marketing, engenharia, finanças e produção em equipes que trabalhassem em conjunto, do que envolver somente profissionais da produção. Essas equipes alteraram a técnica de engenharia de valor criando o target costing, um sistema mais ágil de gerenciamento de custos e planejamento de lucros, revolucionando a indústria japonesa nas décadas de 60 e 70.

A Toyota foi a primeira empresa japonesa a utilizar o target costing, que se popularizou nos meios empresariais nipônicos através de empresas como NEC, Sony, Nissan e Sharp, principalmente em resposta à crise do petróleo. Contudo o target costing só chegou ao Ocidente no final da década de 80, através de obras de autores japoneses traduzidas por alemães e americanos.

A principal vantagem é que o planejamento dos custos é conduzido pela visão de mercado e a redução de custos é baseada em esforços de projeto do processo e produto, com ênfase orientada por informação do cliente. Dessa forma, diz-se que o target costing é um sistema de custeio direcionado ao mercado, que considera as necessidades do consumidor e da competitividade do mercado. Ainda citando Ansari (1997):

Target costing se inicia no gerenciamento de custos nos primeiros estágios de desenvolvimento do produto e é utilizado durante o ciclo de vida do produto através do envolvimento ativo de toda a cadeia de valor.

De fato não existe uma definição comum de target costing, diferentes autores possuem diferentes abordagens e enfoques. A Figura 6 demonstra algumas:

\begin{tabular}{|l|r|r|}
\hline \multicolumn{1}{|c|}{ Abordagem } & Enfoque & Autor \\
\hline Target costing é definido como uma ferramenta de & Ferramenta de & \\
gerenciamento de custos para redução dos custos gerais de & gerenciamento de & SAKURAI \\
fabricação no ciclo de vida dos produtos. Este gerenciamento & custos durante o ciclo & (1989) \\
utiliza a técnica de formação de preço para determinar a & de vida, visando & \\
demanda para maximizar os lucros. & maximizar lucros. & \\
\hline
\end{tabular}

Continua 
Continuação

\begin{tabular}{|c|c|c|}
\hline Abordagem & Enfoque & Autor \\
\hline $\begin{array}{l}\text { Targer Costing é utilizado para trazer o custo alvo e o custo } \\
\text { estimado dentro da linha de melhor especificação e projeto do } \\
\text { produto. }\end{array}$ & $\begin{array}{c}\text { Especificação e projeto } \\
\text { do produto. }\end{array}$ & $\begin{array}{c}\text { TANAKA } \\
\text { (1993) }\end{array}$ \\
\hline $\begin{array}{l}\text { O processo do custeio-alvo proporciona informação à } \\
\text { administração sobre as metas que precisam ser estabelecidas } \\
\text { para custo, qualidade e tempo. }\end{array}$ & $\begin{array}{l}\text { Informação sobre } \\
\text { metas envolvendo } \\
\text { custo, qualidade e } \\
\text { tempo. }\end{array}$ & $\begin{array}{c}\text { HRONEC \& } \\
\text { ANDERSEN } \\
\text { (1994) }\end{array}$ \\
\hline $\begin{array}{l}\text { Target Costing direciona a estratégia de desenvolvimento de } \\
\text { produto mais rápido e diminui o risco com lançamento de } \\
\text { novos produtos. }\end{array}$ & $\begin{array}{l}\text { Estratégia de } \\
\text { desenvolvimento de } \\
\text { produtos. }\end{array}$ & $\begin{array}{c}\text { COOPER } \\
(1996)\end{array}$ \\
\hline $\begin{array}{l}\text { O processo do Target Costing é um sistema de planejamento } \\
\text { de lucros e gerenciamento de custos, direcionado pelo preço, } \\
\text { focado no consumidor, projeto centralizado e multifuncional. }\end{array}$ & $\begin{array}{l}\text { Planejamento de lucros } \\
\text { e gerenciamento de } \\
\text { custos. }\end{array}$ & $\begin{array}{l}\text { ANSARI } \\
\text { (1997) }\end{array}$ \\
\hline $\begin{array}{l}\text { Um método de medir o custo aceitável que pode ser incorrido } \\
\text { ao produto e ainda ganhar uma rentabilidade requerida ao } \\
\text { produto. }\end{array}$ & $\begin{array}{l}\text { Medição de custo e } \\
\text { rentabilidade } \\
\text { requerida. }\end{array}$ & $\begin{array}{c}\text { MINAHAN } \\
\text { (1997) }\end{array}$ \\
\hline $\begin{array}{l}\text { Target Costing (...) é baseado em três premissas: a) preço } \\
\text { direcionado ao mercado; b) tratamento do custo do produto } \\
\text { como uma variável independente; c) trabalho proativo para } \\
\text { acertar o custo alvo durante o desenvolvimento do produto e } \\
\text { do processo. }\end{array}$ & $\begin{array}{l}\text { Preço de mercado; } \\
\text { custo e proatividade. }\end{array}$ & $\begin{array}{l}\text { CROW } \\
\text { (1998) }\end{array}$ \\
\hline $\begin{array}{l}\text { Um sistema de gerenciamento de custos e planejamento } \\
\text { estratégico dos lucros, que traduz os desejos, necessidades e } \\
\text { valores do cliente, em distribuição de produtos e serviços. }\end{array}$ & $\begin{array}{l}\text { Gerenciamento de } \\
\text { custos e planejamento } \\
\text { dos lucros. }\end{array}$ & $\begin{array}{c}\text { FREEMAN } \\
\text { (1998) }\end{array}$ \\
\hline $\begin{array}{l}\text { Como utilizado na Toyta é um rigoroso processo de } \\
\text { engenharia, que utiliza a engenharia de valor para reduzir os } \\
\text { custos de seus produtos. }\end{array}$ & $\begin{array}{l}\text { Processo de engenharia } \\
\text { para redução de custos. }\end{array}$ & $\begin{array}{l}\text { DEAN } \\
(1998)\end{array}$ \\
\hline $\begin{array}{l}\text { Target Costing é um sistema de gerenciamento de custos e } \\
\text { lucro que empresas usam para planejar o portfólio de serviços } \\
\text { e projetar processos e respectiva estrutura dos custos, } \\
\text { proporcionando maior valor aos clientes. }\end{array}$ & $\begin{array}{l}\text { Gerenciamento de } \\
\text { custos e lucro no } \\
\text { planejamento de } \\
\text { serviços. }\end{array}$ & $\begin{array}{c}\text { DUTTON } \\
(1998)\end{array}$ \\
\hline $\begin{array}{l}\text { Um processo de planejamento que tem por objetivo garantir a } \\
\text { obtenção da margem objetivada pela empresa, através do } \\
\text { alcance do custo-alvo, esperando obter uma receita estimada. }\end{array}$ & $\begin{array}{c}\text { Planejamento } \\
\text { garantindo a margem. }\end{array}$ & $\begin{array}{c}\text { VIÉGAS e } \\
\text { CALARGE } \\
\text { (1998) }\end{array}$ \\
\hline
\end{tabular}

Continua 
Continuação

\begin{tabular}{|c|c|c|}
\hline Abordagem & Enfoque & Autor \\
\hline $\begin{array}{l}\text { Uma abordagem estruturada para determinar o custo ao qual } \\
\text { um produto proposto com funcionalidade e qualidade } \\
\text { específica deve ser produzido, gerando um nível desejado de } \\
\text { rentabilidade a um preço de venda estimado. }\end{array}$ & $\begin{array}{l}\text { Abordagem estruturada } \\
\text { visando uma } \\
\text { rentabilidade desejada. }\end{array}$ & $\begin{array}{l}\text { FMAC } \\
(1999)\end{array}$ \\
\hline $\begin{array}{l}\text { Um sistema que incorpora a administração do lucro em toda } \\
\text { empresa durante a etapa de desenvolvimento do produto. }\end{array}$ & $\begin{array}{l}\text { Administração do lucro } \\
\text { durante } \\
\text { desenvolvimento do } \\
\text { produto. }\end{array}$ & $\begin{array}{l}\text { MONDEN } \\
\text { (2001) }\end{array}$ \\
\hline $\begin{array}{l}\text { Dado um produto específico, o Target Costing pode ser um } \\
\text { método adequado para planejar e controlar o processo de } \\
\text { recuperação das saídas de caixa. }\end{array}$ & $\begin{array}{l}\text { Planejamento e } \\
\text { controle do processo de } \\
\text { recuperação das saídas } \\
\text { de caixa. }\end{array}$ & $\begin{array}{l}\text { SUEMATSU } \\
\text { (2000) }\end{array}$ \\
\hline
\end{tabular}

Figura 6 : Target Costing - Definições versus enfoques

Das definições, pode-se tirar algumas conclusões acerca das propriedades do método de custo-alvo:

- enfatizam a redução dos custos e não o controle dos custos,

- indicam a idéia dos custos do produto durante um ciclo de vida,

- evidenciam que a precificação tem como base o ponto de vista do cliente (preço de mercado),

- direcionadas à fase de planejamento e desenvolvimento do produto;

- envolvem toda a cadeia de valores;

- requerem envolvimento de várias partes da empresa (times multifuncionais).

O planejamento do custo de um produto é feito com base no preço competitivo de mercado e no lucro alvo : $\mathrm{C}=\mathrm{P}-\pi$, onde $\mathrm{C}$ é o custo alvo, $\mathrm{P}$ é o preço competitivo e $\pi$ é o lucro alvo. O intuito é atingir a redução de custo objetivada, que é igual ao custo atual, menos o custo pretendido. Para isso, deve-se levar em conta o valor do produto percebido pelos clientes, que esperam cada nova geração de produtos com mais valor. Segundo Porter (1992), valor é aquilo que os compradores estão dispostos a pagar, e o valor superior provém da oferta de preços mais baixos do que os da concorrência por 
benefícios equivalentes ou do fornecimento de benefícios singulares que compensam um preço mais alto.

Isto pode ser alcançado pela melhoria da qualidade, melhoria da funcionalidade do produto ou pela redução do preço de venda. Note-se a diferença entre o sistema de precificação mais utilizado, onde se tomam por base os custos de produção mais um lucro estimado. No custeio-alvo, o preço é definido pelo consumidor, ou seja, quanto o consumidor está disposto a pagar, e pelo lucro alvo. Como demonstra a Figura 7.

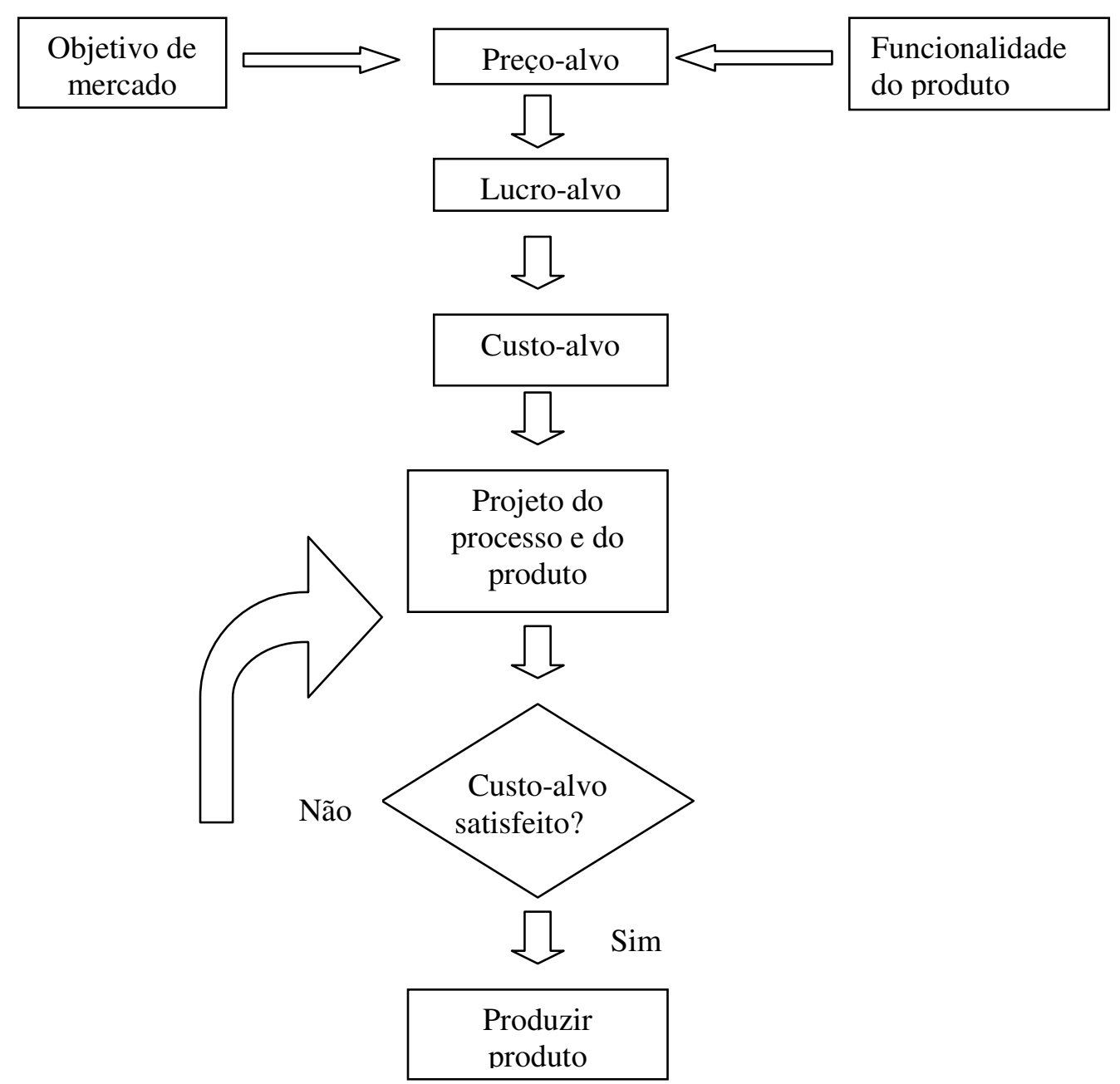

Figura 7: Fluxograma de custeio alvo

São muitas as diferenças conceituais entre a abordagem tradicional de custos e o Target Costing. Scarpin (2000) elaborou um estudo enfocando estas diferenças, tomando como base a literatura existente, que foi resumido na Figura 8, a seguir: 


\begin{tabular}{|c|c|}
\hline Costing & Abordagem tradicional de custos \\
\hline O preço determina o custo. & O custo determina o preço. \\
\hline $\begin{array}{l}\text { Começa com um preço de mercado (ou preço alvo } \\
\text { de venda) e uma margem de lucro planejada, para } \\
\text { depois estabelecer um custo permissível (ou custo } \\
\text { alvo). }\end{array}$ & $\begin{array}{l}\text { Estima um custo de produção, depois } \\
\text { acrescenta uma margem de lucro } \\
\text { desejada para então se obter um preço de } \\
\text { venda. }\end{array}$ \\
\hline $\begin{array}{l}\text { Planejamento de custos é guiado pelo mercado } \\
\text { competitivo. }\end{array}$ & $\begin{array}{l}\text { As considerações de mercado não são } \\
\text { consideradas no planejamento de custos. }\end{array}$ \\
\hline $\begin{array}{l}\text { Reduções de custos são feitas antes que os custos } \\
\text { cheguem a seu limite aceitável. }\end{array}$ & $\begin{array}{l}\text { Reduções de custos são feitas depois que } \\
\text { os custos são incorridos além do limite } \\
\text { aceitável. }\end{array}$ \\
\hline $\begin{array}{l}\text { O projeto (de produtos e processos) é a chave para } \\
\text { reduções de custos. }\end{array}$ & $\begin{array}{l}\text { Perdas e ineficiências são o foco da } \\
\text { redução de custos. }\end{array}$ \\
\hline $\begin{array}{l}\text { Reduções de custos são guiadas pelos desejos e } \\
\text { anseios do consumidor. }\end{array}$ & $\begin{array}{l}\text { Redução de custos não são dirigidas aos } \\
\text { clientes. }\end{array}$ \\
\hline $\begin{array}{l}\text { Custos são gerenciados por equipes multifuncionais } \\
\text { (toda a empresa). }\end{array}$ & $\begin{array}{l}\text { Os custos são monitorados apenas pelos } \\
\text { contadores. }\end{array}$ \\
\hline $\begin{array}{l}\text { Fornecedores são envolvidos no conceito e no } \\
\text { projeto. }\end{array}$ & $\begin{array}{l}\text { Os fornecedores são envolvidos apenas } \\
\text { na fase de produção (depois do projeto } \\
\text { pronto). }\end{array}$ \\
\hline $\begin{array}{l}\text { Minimiza o custo de propriedade para o } \\
\text { consumidor. }\end{array}$ & $\begin{array}{l}\text { Minimiza apenas o preço pago pelo } \\
\text { consumidor. }\end{array}$ \\
\hline $\begin{array}{l}\text { Envolve toda a cadeia de valor (para definição ver } \\
\text { 4.3.2) no planejamento de custos. }\end{array}$ & $\begin{array}{l}\text { Pouco ou nenhum envolvimento da } \\
\text { cadeia de valor (para definição ver } \\
\text { 4.3.2) no planejamento de custos. }\end{array}$ \\
\hline
\end{tabular}

Figura 8 : Diferenças entre o target costing e sistema de custeio tradicional Fonte: Scarpin (2000, grifo nosso)

Com relação aos objetivos de ajustes ou controle, o target costing tem como objetivo a melhoria contínua do custo, tanto para os consumidores, quanto para produtores em todo o ciclo de vida, diferentemente da abordagem tradicional, que mantém os custos em limites pré-estabelecidos por padrões ou orçamentos.

Depois de visitados alguns sistemas de custeio, fica patente que diferentes bases e enfoques podem ser dados ao tema custo, mesmo sendo estes dedicados ao ambiente de produção. Todavia remanesce a pergunta de como custear em um ambiente logístico. 
Algumas soluções a essa questão são demonstradas nos próximos tópicos.

\subsection{Técnicas de custeio da cadeia de suprimentos}

De acordo com Pohlen e LaLonde (1996) desde o início dos anos 60 existe uma maior preocupação com apuração e análise dos custos na logística. Além disso, conceitos relativos ao gerenciamento da cadeia logística têm crescido em importância no ambiente empresarial.

Empresas enfrentam problemas para selecionar a combinação de canais de distribuição e parceiros na cadeia de suprimentos com o mais rentável mix de estoques. Como resultado, gerentes logísticos têm, repetidamente, necessitado da capacidade de isolar os custos logísticos por função, território, produto, canal, método de venda, tamanho do pedido, método de entrega, etc. Contudo nenhum método se mostrou satisfatório em prover as informações necessárias. Novas técnicas de custeio, tais como Direct Product Profitability (DPP), Costumer Profitability Analysis (CPA) e Total Cost of Ownership (TCO) têm fornecido informações úteis, mas não satisfatoriamente endereçadas a cadeia de suprimentos como um todo.

Apesar do foco deste trabalho diferir da cadeia como um todo, em continuação aborda-se cada um dos métodos de custeio citados que são endereçados a logística.

\subsubsection{Lucratividade direta por produto}

A lucratividade direta por produto representou o primeiro esforço significativo para determinar os custos de mover um produto através de uma cadeia de suprimentos inteira.

Esse método de custeio demonstra a lucratividade do produto subtraindo da margem de contribuição os custos diretamente atribuídos aos produtos, e utiliza parcialmente o conceito do custeio variável (método de custeio que atribui apenas custos de manufatura variáveis aos produtos, estes incluem materiais diretos, mão-deobra direta e CIF variáveis. Os CIF fixos são tratados como custos do período e são alocados no resultado no período incorrido). Pois, são deduzidos da receita de vendas os gastos variáveis e, então, identificam-se e medem-se os gastos diretamente alocáveis ao produto, como mão-de-obra, espaço, estoque e transporte. 
Na Figura 9 são descritas as etapas para a mudança de medição simples da contribuição marginal para a lucratividade direta por produto, que representa a contribuição líquida pelas vendas de um produto, depois de adicionadas as sobretaxas e subtraídos todos os gastos que possam ser racionalmente alocados ou atribuídos ao produto individualmente.

\section{Vendas}

(-) Custo das mercadorias vendidas

(=) Lucro bruto + Sobretaxas e desconto

(=) Lucro bruto ajustado

(-) Custos do Armazém Mão-de-Obra

Instalações (área e cubagem)

Estoque (estoque médio)

(-) Custo de transporte (cubagem)

(-) Custo do varejo

Mão-de-Obra de estocagem

Mão-de-Obra dos balconistas

Instalações

Estoque

(=) Lucro Direto do Produto

Figura 9 : Etapas do modelo de obtenção da Lucratividade Direta por Produto (DPP) Fonte: Christopher (1997)

Christopher (1997) afirma que o maior benefício da lucratividade direta por produto - DPP - para o fornecedor vem do fato de se valorizar a estratégia do serviço ao cliente como fator importante para reduzir os seus custos na obtenção do produto.

Em outras palavras, o fornecedor deve olhar para o seu produto e fazer a pergunta: 'Como posso influenciar favoravelmente a DPP dos meus clientes, alterando as características dos produtos que eu vendo ou a maneira pela qual distribuo estes produtos? (CHRISTOPHER, 1997) .

Sob a ótica dos fornecedores, a compreensão da DPP se torna importante porque a sobrevivência como fornecedor dependerá dos custos que irão ocorrer à medida que o produto se desloca através do seu sistema logístico. Da mesma forma que distribuidores e varejistas estão muito mais conscientes da importância de um item, é importante que os fornecedores conheçam os fatores que causam impacto em sua DPP.

Considerando que as características de cada produto e seus custos associados variam de item para item, devido a volume, peso, embalagem, espaço ocupado, custo de manuseio de estoques e giro, os gerentes que lidam com armazenamento podem 
considerar a DPP de cada item. Como espaço físico é um fator limitante para quem trabalha com suprimentos, o metro quadrado ocupa um papel chave no DPP.

Existem vários fatores que o fabricante ou fornecedor podem variar para alterar a DPP de um produto, como tamanho das caixas e paletes, aumento da freqüência de entregas e entregas diretamente às lojas. Shank e Govindarajan (1997) citam o caso de um fornecedor de chocolate para uma fábrica.

A matéria-prima era entregue em barras de quatro quilos, a fábrica recebia as barras, derretia e as convertia em barras de tamanho menor. O fornecedor percebeu que a entrega da matéria-prima em formato de barras, além de desnecessária, representava um custo adicional. Decidiu-se entregar o chocolate derretido em caminhões tanque e, com isso, reduziram-se os custos do fornecedor de chocolate e do fabricante.

Contudo, segundo os autores, como a DPP exclui custos "fixos" de overhead tais como supervisão, facilidades, gerenciamento, compras e custos de cuidados com inventário. E tem sido usada de modo limitado, porque nunca foi totalmente integrada nos sistemas dos distribuidores, já que demanda manter um extenso banco de dados de características físicas e atualizá-lo continuamente.

\subsubsection{Custeio total de aquisição}

O custeio total de aquisição representa uma tentativa recente de custear uma porção específica da cadeia de suprimentos. O método reconhece que o preço de compra representa apenas uma porção do custo total de adquirir um item. Para Carr e Ittner (1992) o custo total de aquisição é uma aproximação estruturada para determinar o custo total associado com a aquisição e subseqüente uso de um dado item ou serviço de um dado fornecedor.

Companhias têm utilizado o custeio total de aquisição - TCO - como um meio de medir e avaliar seus fornecedores. Atribuir custos às atividades afetadas pela decisão do comprador fornece uma outra ferramenta na decisão do fornecedor. Os compradores podem avaliar os vendedores alternativos, baseados nos custos associados com o número de retornos do produto, de lotes errados, de não conformidades, ou de entregas atrasadas. As companhias que incorporam estes fatores em sua análise de compra podem melhor determinar que fornecedores lhes oferecem o melhor valor total. 
Degraeve, Labro e Roodhooft (2000) afirmam que as atividades de aquisição podem ser dividas em três níveis hierárquicos:

- primeiro nível: constitui o nível dos fornecedores. As atividades são desempenhadas nesse nível apenas se um dado fornecedor está sendo utilizado. Os custos nesse nível relacionam-se com o controle do padrão de qualidade desse fornecedor, salários de compradores e gerentes de suprimentos que se relacionam diretamente com os fornecedores;

- $\quad$ segundo nível: é chamado de nível das ordens. As atividades ocorrem cada vez que uma ordem de compra é dada para um determinado fornecedor. Os custos poderiam incluir, por exemplo, custos de recebimento, custos de transporte, custos de comunicação, etc.;

- $\quad$ terceiro nível: no nível das unidades. As atividades são relacionadas com as unidades dos produtos em uma ordem específica. Isso poderia ocorrer devido a custos adicionais em uma linha de produção devido a falha de um componente adquirido de um determinado fornecedor. Os custos de administração de estoques também estão inclusos neste nível.

Segundo Ellram (1998), pode-se dividir os custos que afetam os suprimentos em quatro categorias, conforme Figura 10.

\begin{tabular}{|c|c|}
\hline Categorias & Custos \\
\hline Qualidade & $\begin{array}{ll}\text { - } & \text { Inspeção; } \\
\text { - } & \text { Retorno; } \\
\text { - } & \text { Defeitos durante a produção; } \\
\text { - } & \text { Treinamento de fornecedores; } \\
\text { - } & \text { Retrabalho. } \\
\end{array}$ \\
\hline Entrega & $\begin{array}{l}\text { - Atraso ou adiamento da entrega; } \\
\text { - Transportes; } \\
\text { - Tempo de ciclo (Lead time); } \\
\text { - Movimentação de estoque extra; } \\
\text { - Expedição. }\end{array}$ \\
\hline Serviço ao consumidor & $\begin{array}{l}\text { - Atrasos no atendimento; } \\
\text { - } \quad \text { Adaptação de sistemas de informação; } \\
\text { - } \quad \text { Engenharia de suporte; } \\
\text { - } \quad \text { Reajustes de quantidades, preços, etc.; }\end{array}$ \\
\hline Preço & $\begin{array}{l}\text { - Preço pago; } \\
\text { - Termos de pagamentos; } \\
\text { - Redução nos preços por conta. }\end{array}$ \\
\hline
\end{tabular}

Figura 10 : Categorias de custos envolvidas no TCO

Fonte: Ellram (1998) 
Para uma melhor compreensão do custeio total de aquisição é citado o caso da empresa Northrop Aircraft Division - NAD -, descrito por Carr e Ittner (1992). A NAD possui um sistema de avaliação de fornecedores no qual são medidas as despesas administrativas relativas a correções de falhas de seus fornecedores (deficiências na entrega, burocracia, retrabalho, etc.). A Tabela 1 apresenta alguns tipos de não conformidades, como a quantidade de horas despendidas para a sua solução e seus custos. Para cada evento (não conformidade), o número de ocorrências durante o último período é multiplicado pelo custo unitário da não conformidade, obtendo-se assim, o custo de não conformidades. Com base no exposto, um índice de desempenho de fornecedores (IDF) é calculado da seguinte forma:

IDF $=\underline{\text { Custos de não conformidade }+ \text { Preço de Compra }}$

Preço de Compra

O preço de compra refere-se aos gastos de aquisição das mercadorias compradas de determinado fornecedor durante o período.

Tabela 1: Custo Padrão das não conformidades da Northrop Aircraft Division.

\begin{tabular}{l|c|c}
\hline \multicolumn{1}{c|}{ Não conformidades } & $\begin{array}{c}\text { Horas padrão para } \\
\text { correção }\end{array}$ & $\begin{array}{c}\text { Custo Padrão } \\
\text { (hrs. x \$ 50) }\end{array}$ \\
\hline Documentação & 3 & $\$ 150,00$ \\
Inspeção de entrada de material & 12 & $\$ 600,00$ \\
Retorno ao fornecedor & 6 & $\$ 300,00$ \\
Retrabalho & 15 & $\$ 750,00$ \\
Descarregamento & 7 & $\$ 350,00$ \\
Carregamento & 2 & $\$ 100,00$ \\
Atraso na entrega & 10 & $\$ 500,00$ \\
\hline
\end{tabular}

Fonte: Carr e Ittner (1992)

O exemplo a seguir ilustra o método usado para o cálculo do IDF de um fornecedor da NAD em um período. Os valores monetários utilizados neste exemplo foram extraídos da Tabela 1:

Gasto de aquisição dos produtos:

\$250.000

\section{Custos de Não Conformidade:}

Retorno ao Fornecedor: (2 ocorrências x \$300)........................... \$ \$ 600 
Descarregamento: (5 ocorrências x $\$ 350)$...

Atrasos na entrega de produtos: (3 ocorrências x \$500)

Custo Total de Não Conformidade:

$$
\mathrm{IDF}=\frac{\$ 3.850+\$ 250.000}{\$ 250.000}=1,015
$$

A avaliação/seleção de fornecedores é realizada com base nesse índice. Para

\begin{tabular}{|c|c|c|}
\hline & Fornecedor A & Fornecedor B \\
\hline Preço de Compra Unitário & $\$ 100$ & $\$ 105$ \\
\hline $\mathrm{x}$ IDF & 1,1 & 1,0 \\
\hline Custo Total Unitário & $\$ 110$ & $\$ 105$ \\
\hline
\end{tabular}
uma melhor visualização, pode-se observar a comparação entre dois fornecedores:

Analisando-se somente o preço de compra, pode-se concluir que o fornecedor A é mais atraente que o fornecedor B. Entretanto, sob a ótica do TCO, o fornecedor B torna-se melhor que o A.

Ellram (1995) tece alguns comentários em sua pesquisa, resultado de um estudo com 11 empresas que utilizam o TCO, mostrando que os principais motivos para adoção desse método de custeio são: suporte decisório para a seleção de fornecedores, estabelecimento de medidas para a avaliação de desempenho dos fornecedores e direcionamento para mudança de processos organizacionais. Além disso, evidenciou-se que a maioria (7) utiliza o TCO apenas como ferramenta de seleção de fornecedores, e não, complementarmente, como base para avaliação de desempenho.

Ainda, o autor relacionou os benefícios, estreitamente relacionados entre si, da adoção do TCO em cinco categorias:

1. Medidas de desempenho. O TCO fornece uma boa estrutura para a avaliação de fornecedores, além de ser uma maneira concreta de se medir resultados de esforços de melhoria contínua. O TCO demonstra ser uma boa ferramenta para benchmarking;

2. Suporte decisório. Demonstra-se interessante para a seleção de fornecedores, força a equipe de compras das empresas a compreenderem 
os trade-offs e cria uma forma estruturada para a solução de problemas de aquisição de materiais.

3. Comunicação. Constitui um veículo de comunicação entre as empresas e seus fornecedores e viabiliza a integração com outras funções da empresa no processo de aquisição.

4. Auxílio à compreensão de dados. Proporciona dados para a comparação do desempenho de fornecedores, dados para negociações e para a formação de preço alvo. Requer do pessoal de compras uma compreensão dos fatores (que extrapolam a simples análise baseada no preço de aquisição) mais significantes para a formação dos custos de aquisição.

5. Suporte ao processo de melhoria contínua. Identifica onde os fornecedores devem focalizar seus esforços de melhoria, auxilia na identificação de oportunidades para corte de custos desnecessários, obriga padronização de processos internos.

Porém, Milligan (1999) relata algumas dificuldades na implantação do TCO, tais como resistência a mudanças, falta de treinamento e educação do pessoal envolvido no processo de aquisição, etc.

\subsubsection{Análise da lucratividade de clientes}

A análise da lucratividade de clientes - CPA - parte da premissa que as atividades associadas aos clientes são distintas das relacionadas a produtos. Em geral, elas são desempenhadas nas fases de planejamento do transporte, carregamento, manuseio e descarga.

Definir a lucratividade de clientes é uma das questões que a contabilidade tradicional tem dificuldade em solucionar. Em geral, os sistemas de informação de gestão de custos tradicionais calculam a lucratividade de seus clientes, com base no lucro bruto, ou seja, a receita bruta de vendas gerada pelo cliente em certo período, menos o custo das mercadorias vendidas. Entretanto existem muitos outros custos que devem ser considerados antes de se definir a lucratividade real de um certo cliente. 
A importância desses custos, que são ocasionados pela realização de atividades como prestação de serviços ao cliente, pode ser relevante em termos de como as estratégias logísticas devam ser desenvolvidas. Normalmente, a CPA revelará clientes que proporcionam uma contribuição negativa para os lucros de uma organização.

O princípio básico do CPA é que o fornecedor oriente todos os custos específicos de seus clientes para contas individuais. Em um negócio com milhares de contas de clientes, não seria possível fazer a análise individual da lucratividade de clientes. Entretanto, seria possível selecionar uma amostra representativa, de modo a obter uma visão dos custos relativos associados com diferentes tipos de clientes, canais de distribuição, ou segmentos de mercado.

O ponto de partida da análise da lucratividade de clientes é o valor das vendas brutas do pedido, do qual são subtraídos os descontos concedidos ao cliente naquele pedido. A seguir, são relacionados os custos de todas as atividades consumidas pelos clientes ou grupos de clientes e subtraídos os custos dessas atividades do valor das vendas líquidas. A Figura 11 é um exemplo dos possíveis custos que podem ser relacionadas aos clientes.

Comissões de vendedores

\section{Custos das vendas}

Estrutura de vendas

Bônus comerciais e descontos especiais

Custo de gerenciar contas-chave

Custo de processar pedidos

Custo de comercializar

Custo de embalar pedidos

Custo de manter estoques

Custo de manter espaço físico do armazém

Custo de manusear materiais

Custo de transporte interno de materiais

Custo de transportar produtos

Custo de receber pedidos

Custos de documentar pedidos

Custos de comunicar pedidos

Custos de devolucão

Figura 11 : Possíveis custos relacionados com clientes

Fonte: Manning (1998)

Observe-se que os custos relacionados com clientes dependem das características dos setores de atividades, juntamente com o tipo de canal de distribuição. Por exemplo, consumidores da indústria alimentícia geram altos custos na área de 
marketing, pesquisa e desenvolvimento de novos produtos, demandados por clientes específicos e de suporte ao cliente.

Este enfoque sobre os custos dirigidos aos clientes provê aos tradicionais sistemas de custeio solução a algumas falhas, como insensibilidade a estes custos, uma vez que não variam com o volume e são relativamente pequenos, e cálculo do lucro líquido, já que nos sistemas de custeio tradicional obtém-se o lucro bruto subtraindo-se da receita bruta de vendas, gerada pelos clientes em certo período, o custo das mercadorias vendidas.

A alocação dos custos das atividades de vendas, marketing, distribuição e administração para os clientes deve ser realizada de forma coerente, posto que nem todos os consumidores utilizam tais atividades da mesma forma e com a mesma freqüência. A análise da lucratividade de clientes permite que se classifique os clientes em segmentos diferenciados. Dessa forma, pode-se planejar um relacionamento diferente para cada tipo de cliente.

A segmentação dos clientes, com base em sua lucratividade, permite às empresas estabelecer estratégias diferentes para a atuação junto aos mesmos. Cooper e Kaplan (1999) propuseram uma matriz, Figura 12, que definem orientações gerais para um posicionamento estratégico.

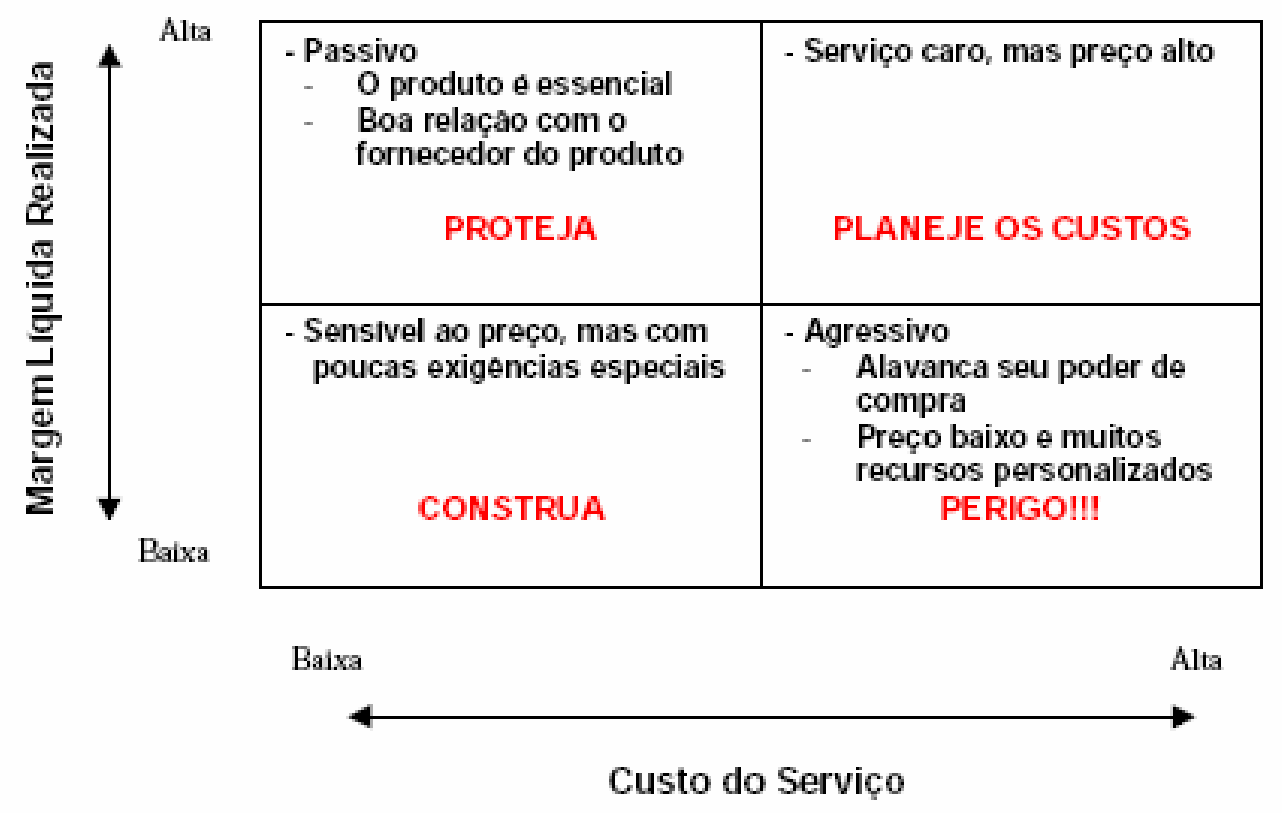

Figura 12: Matriz de lucratividade por cliente Fonte: Cooper e Kaplan (1999)

Cada quadrante da matriz significa um segmento de clientes atendidos pela empresa, o eixo da horizontal representa o custo do serviço ao cliente e o eixo vertical a 
margem líquida resultante das vendas. Se o custo de prestação de serviço para os clientes é baixo e o valor da margem líquida das vendas também, deve-se verificar a possibilidade do aumento do volume de vendas sem um aumento proporcional nos custos dos serviços. Caso um determinado cliente utilize um serviço caro e que possui uma pequena margem líquida, deve-se olhar este cliente com cuidado. A estratégia para essa classe de clientes deve levar em consideração a possibilidade de melhoria do valor líquido das vendas ou diminuição dos custos do serviço, e ainda verificar se existe alguma razão estratégica para conservar esses clientes. Mesmo que a margem de lucro seja baixa, esses clientes podem ser necessários pelo volume de vendas que ele representam.

Um planejamento minucioso dos custos faz-se necessário quando um cliente utiliza serviços de alto custo e com boa margem líquida. A análise deve observar a existência de algum campo para aumentar o tamanho das entregas, consolidação das mesmas ou criar canais alternativos para obter os pedidos desses clientes, tais como televendas e pedidos feitos pela internet. Clientes que utilizam serviços relativamente baratos, porém bastante rentáveis, devem ser protegidos, ou seja, fidelizados, buscando constantemente oportunidades de aumento de volume de negócios realizados com eles.

Planejar para fidelizar, jargão executivo que remete à idéia de gestão, neste caso, a gestão de custos. Este tema será abordado no próximo item através de um prisma contemporâneo.

\subsection{Gestão estratégica de custos}

Da mesma forma que houve uma transição da tradicional contabilidade de custos para a análise gerencial de custos, tem-se uma nova perspectiva definida como gestão estratégica de custos (Strategic Cost management - SCM). O pano de fundo desta última evolução é o destaque crescente da estratégia na análise dos negócios. O que se observa é que a gestão tradicional de custos tem como objetivo apenas identificar o impacto financeiro das diferentes decisões administrativas que ocorrem dentro de uma empresa.

De acordo com a nova linha de pensamento representada pela gestão estratégica de custos (SCM), através do entendimento da estrutura de custos de uma empresa, visando um contexto mais amplo, os elementos estratégicos são considerados na elaboração das informações de custos. Estes elementos são, por sua vez, utilizados para 
se desenvolver políticas de obtenção de um bom posicionamento competitivo e facilitar as atividades de planejamento e implementação de uma estratégia de negócios.

Após a década de 80 e até atualmente, o meio competitivo passa a se caracterizar pela mudança tecnológica, pelo acirramento da competição (global e local), pelo surgimento de tecnologias avançadas de produção - JIT (Just-in-Time) e TQC (Total Quality Control) -, pela expansão do processamento de informações e pela maior ênfase na importância da produção enquanto fator de sucesso competitivo. Essas características "ambientais" não combinam mais com os tradicionais sistemas de contabilidade gerencial. Portanto uma série de conceitos fundamentais, dentre os quais a apropriação de custos aos produtos e serviços, estariam necessitando de uma revisão. Esses sistemas da forma como estão desenhados, não estão mais proporcionando a informação precisa e oportuna necessária para que as empresas realizem suas operações e tomem suas decisões tendo em vista essa nova realidade.

A gestão estratégica de custos envolve o uso de dados de custos para desenvolver e identificar estratégias superiores que produzirão uma vantagem competitiva sustentável. E o objetivo da gestão estratégica de custos é reduzir custos enquanto, simultaneamente, fortalece a estratégia adotada. Para análise estratégica, as atividades são divididas em organizacionais e operacionais, os custos dessas atividades são determinados por direcionadores de custos organizacionais e operacionais.

As atividades organizacionais podem ser estruturais, que determinam a estrutura econômica subjacente da organização, e execucionais, que definem os processos e as capacidades de uma organização. Do mesmo modo, os direcionadores de custos organizacionais podem ser divididos em estruturais e execucionais. A Tabela 2 demonstra possíveis atividades e direcionadores organizacionais.

Tabela 2: Direcionadores e atividades organizacionais

\begin{tabular}{cc}
\hline Atividades estruturais & Direcionadores de custos estruturais \\
\hline Construir fábricas & Número de fábricas, escala, grau de \\
centralização
\end{tabular}

Continua 
Continuação

\begin{tabular}{cc}
\hline Atividades estruturais & Direcionadores de custos estruturais \\
\hline Integrar verticalmente & Escopo, poder de compra, poder de venda \\
Selecionar e usar tecnologias de processo & Tipos de tecnologias do processo, \\
& experiência \\
\hline
\end{tabular}

\begin{tabular}{cc}
\hline Atividades de execução & Direcionadores de custos de execução \\
\hline Usar empregados & Grau de envolvimento \\
Fornecer qualidade & Abordagem da gestão de qualidade \\
Fornecer layout da fábrica & Eficiência do layout da fábrica \\
Projetar e produzir produtos & Configuração dos produtos \\
Fornecer capacidade & Utilização de capacidade \\
Fonte: Hansen e Mowen (2001) &
\end{tabular}

Atividades operacionais são resultado dos processos e da estrutura selecionados pela organização, como movimentar materiais, despachar produtos, receber e inspecionar peças entrantes, etc. Os direcionadores de custos operacionais são os direcionadores de atividades, já abordados pelo método de custeio ABC. A Tabela 3 lista algumas atividades operacionais e seus direcionadores.

Tabela 3: Direcionadores e atividades operacionais

Atividades em nível unitário Direcionadores em nível unitário

\begin{tabular}{cc}
\hline Retificar peças & Horas máquinas de retificação \\
Montar peças & Horas de mão-de-obra de montagem \\
Perfurar orifícios & Horas máquina de perfuração \\
Usar materiais & Quilos de materiais \\
Usar energia & Número de quilowatts-hora \\
\hline Atividades em nível de lote & Direcionadores em nível de lote \\
\hline Montar equipamento & Número de montagens \\
Movimentar lotes & Número de movimentos \\
Inspecionar lotes & Horas de inspeção \\
Retrabalhar produtos & Número de unidades defeituosas
\end{tabular}

Continua 
Continuação

\begin{tabular}{cc}
\hline Atividades em nível de produto & Direcionadores em nível de produto \\
\hline Reprojetar produtos & Número de pedidos de mudança \\
Atividades em nível unitário & Direcionadores em nível unitário \\
Atividades em nível unitário & Direcionadores em nível unitário \\
Executar prontamente & Número de pedidos atrasados \\
Programar & Número de produtos diferentes \\
Testar produtos & Número de procedimentos \\
Fonte: Hansen e Mowen (2001) & \\
Embora as atividades organizacionais definam as atividades operacionais, a \\
análise das atividades e dos direcionadores operacionais deve ser usada como base de \\
decisões acerca de atividades e direcionadores organizacionais.
\end{tabular}

\subsection{Considerações}

Após essa breve abordagem sobre custos, pode-se inferir que os métodos de custeio utilizados em ambientes de produção, primordialmente, carecem de dados adequados para o ambiente logístico.

Fatores implícitos às atividades logísticas impõem diferentes métricas. Tomese, por exemplo, uma atividade de produção como fresar, cuja saída é facilmente quantificada e encontra correspondência em outras atividades de produção como cortar. Porém uma atividade logística, como carregar um contêiner, difere em saída de uma atividade como separar itens de um pedido. Apesar, destas ultimas produzirem uma unidade de armazenagem completa (contêiner, palete e etc.) a complexidade e o tempo de ambas variam bastante.

Pensando na cadeia de suprimentos, fatores como tamanho do lote de entrega, frequiência de entrega e volume utilizado no canal alteram o modo de operação de todos os seus elos, influindo diretamente em seus custos, além de representarem a conexão para custeio das atividades de logística de distribuição.

Para situar o assunto custos num ambiente de logística de distribuição, o próximo capítulo aborda os custos logísticos de distribuição e anuncia como será tratado, neste trabalho, o tema cadeia de suprimentos. 


\section{CAPÍTULO 3 - SOBRE LOGÍSTICA}

Este capítulo do trabalho aborda conceitos sobre logística, e sua evolução, a questão do valor e a cadeia de suprimentos. Essa abordagem tem como objetivo esclarecer algumas características deste processo empresarial através do ponto de vista contábil, evidenciando os custos incorridos nas atividades logísticas e seus relacionamentos. Além disso, este capítulo se presta a estabelecer as bases das variáveis utilizadas no trabalho.

\subsection{Conceitos básicos}

O dicionário Aurélio define a logística como:

Parte da arte da guerra que trata do planejamento e da realização de:

a) projeto e desenvolvimento, obtenção, armazenamento, transporte, distribuição, reparação, manutenção e evacuação de material (para fins operativos ou administrativos);

b) recrutamento, incorporação, instrução e adestramento, designação, transporte, bem-estar, evacuação, hospitalização e desligamento de pessoal;

c) aquisição ou construção, reparação, manutenção e operação de instalações e acessórios destinados a ajudar o desempenho de qualquer função militar;

d) contrato ou prestação de serviços. (FERREIRA, 1999)

Como se pode observar, a logística está ligada à guerra; de fato, o conceito de logística teve origem bélica. Advém da palavra loger, do francês, significando acomodar, suprir e movimentar tropas. A primeira tentativa de definir logística, segundo Thorpe (1986), foi do Barão Henri de Jomini, um general de Napoleão, em seu compêndio Arte da Guerra, no qual declara que a logística é "a arte da prática de movimentar exércitos, ou seja, tudo ou quase tudo no campo das atividades militares, exceto o combate". 
Apesar de útil, esse conceito militar de logística não reflete o que a logística significa no meio empresarial. Para o Centro para Estudos de Transportes do Masschusetts Institute of Technology, logística é o gerenciamento do fluxo de itens, informações, dinheiro e idéias, através da coordenação dos processos da cadeia de suprimentos, e através da utilidade de lugar, tempo e forma.

O Council of Supply Chain Management Professionals (2005) (antigo Council Logistics Management - CLM) define logística como parte dos processos da cadeia de suprimentos que planeja, implementa, e controla a eficiência e eficácia do fluxo, para frente e reverso, da armazenagem de bens, serviços, e informações relacionadas entre o ponto de origem e o ponto de consumo para atender aos requisitos dos consumidores.

De acordo com o referido conselho, as fronteiras e relações da gerência das atividades logísticas incluem, tipicamente, gerenciamento do transporte de entrada e saída, da frota, armazenagem, manipulação de materiais, execução de pedidos, projeto de rede da logística, gerência de inventário, planejamento da relação suprimento/demanda, e gerência de fornecedores de serviços da logística de terceiros.

Em variados graus, a função da logística inclui também o abastecimento e a obtenção, o planejamento e programação da produção, empacotamento e montagem de pedidos e o serviço ao cliente. Está envolvida em todos os níveis do planejamento, da execução a estratégicos, operacionais e táticos. A gerência da logística é uma função integradora, que coordena e otimiza todas as atividades da logística, bem como integra atividades da logística com outras funções incluindo marketing, vendas, finanças e tecnologia de informação.

Para Robles (2001, p.28), o conceito de Logística pode ser entendido a partir do que se convencionou denominar os 7C's (de sete certos) da logística: "Assegurar a disponibilidade do produto certo, na quantidade certa, na condição certa, no lugar certo, no momento certo, para o cliente certo, ao custo certo".

Dessas definições, pode-se observar que a logística agrega valor de lugar, tempo, qualidade e de informação à cadeia produtiva, como diz Novaes (2001). Por mais primitivo que seja um sistema logístico, ele agrega valor de lugar, pois elimina a distância entre produção e consumo. Agrega valor tempo, pois, disponibiliza uma solução ao cliente em tempo hábil. E o valor de qualidade, relacionado às especificações declaradas do produto ou serviço, e que se espera, estejam em conformidade com as condições reais. Além disso, tem-se o valor da informação, que pode servir para controle de estoque, correção de táticas de suprimento, segurança e etc. 
Ballou (2001) afirma que qualquer negócio pode gerar quatro tipos de valor: forma, posse, tempo e lugar. A utilidade de forma está relacionada ao fato de o produto estar disponível e pronto para uso / consumo, e a utilidade de posse está ligada ao valor efetivo quando o cliente pode adquirir o produto / serviço onde e quando precisar.

De forma mais ampla, as utilidades da logística muito se relacionam às suas funções, sendo estas resultantes da agregação de algumas atividades ao longo do tempo, decorrentes da mudança do foco gerencial. Deste modo, faz-se conveniente averiguar a evolução da logística.

\subsection{Evolução da logística}

Para Bowersox, Closs e Helferich (1986) as funções logísticas, antes da década de 1950, eram consideradas como trabalho de apoio ou facilitadoras, a responsabilidade pela logística era dispersa pela empresa e, conseqüentemente, os trabalhos logísticos não coordenados interfuncionalmente, resultando, freqüentemente, em duplicação e desperdício. Pelas distorções das informações, confusão da autoridade / responsabilidade e pela reconhecida necessidade de controle do custo total, executivos começaram a reorganizar e combinar funções logísticas em um único grupo gerencial, resultando numa estruturação da logística como função integrada.

A crença era de que o agrupamento de funções logísticas num mesmo corpo gerencial iria aumentar a probabilidade de integração. Tal princípio, de integração baseado na proximidade, prevaleceu até meados da década de 1980, quando as questões principais não mais eram funções e sim processos, conduzindo a um novo modo de pensar com relação à melhor maneira de alcançar o desempenho logístico integrado. $\mathrm{O}$ principal ponto não era como organizar funções individuais, mas qual a melhor forma de gerenciar o processo logístico como um todo. Os desafios e oportunidades da desagregação funcional e da integração orientada pela informação começaram a emergir.

A missão da logística passou a ser posicionar estoque quando e onde ele fosse necessário, de modo a viabilizar vendas lucrativas. A característica contínua desse trabalho de apoio significa que a logística deve ser parte integrante de todos os processos; para isso, a ideal estrutura para logística seria uma organização que executasse o trabalho essencial como parte dos processos aos quais dá apoio, obtendo, ao mesmo tempo, a sinergia da integração interfuncional. 
A tecnologia de informação introduziu a possibilidade da integração eletrônica em oposição à combinação física de funções logísticas, permitindo a distribuição da responsabilidade pela organização, demandando a combinação da logística com outras áreas, como marketing e manufatura. Ao invés de questões como transporte versus estoque, tem-se o desafio de integrar transporte, estoque, produção flexível, serviço ao cliente e desenvolvimento de novos produtos.

Para isso, departamentos unifuncionais tiveram que ser absorvidos por um processo, e isso exigiu que as estruturas organizacionais tradicionais fossem desagregadas e, em seguida, reorganizadas de maneiras novas e singulares. O novo formato da organização caracteriza-se por uma cultura extremamente diferente com relação à maneira como a informação é gerenciada e compartilhada.

Para o entendimento do posicionamento estrutural e da administração de mudanças, torna-se bastante útil examinar a forma como as organizações burocráticas evoluíram. Para Bowersox, Closs e Helferich (1986), embora a evolução organizacional possa ser acelerada, parece improvável a possibilidade de se pular estágios. A Figura 13 mostra os cinco estágios de desenvolvimento organizacional, com base na importância relativa dada à agregação funcional e à integração de informação.

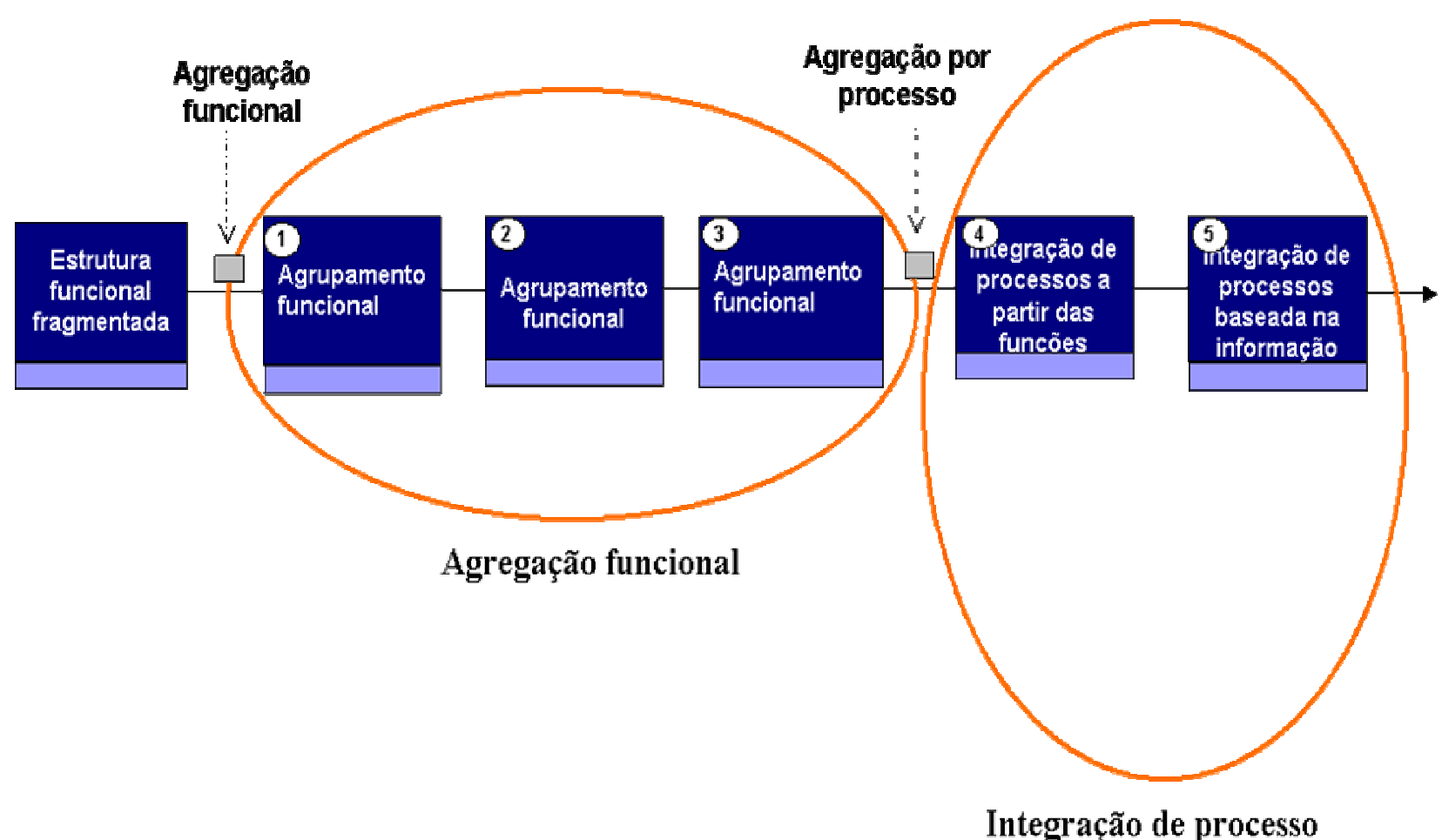

Figura 13 : Estágios evolutivos da logística

Fonte: Bowersox, Closs e Helferich (1986) 
Assim como os autores supracitados, Ching (1999) corrobora a idéia de integração, afirmando que, antes de 1950, o campo da logística permanecia adormecido. Não existia nenhuma filosofia dominante para guiá-lo. As empresas fragmentavam a administração das atividades-chave em logística. De outra maneira, o transporte era encontrado freqüentemente sob o comando gerencial da produção, os estoques eram responsabilidade de marketing, finanças ou produção, e o processamento de pedidos era contratado por finanças ou vendas. À medida que a integração passou a ser pensamento dominante, as funções logísticas, dispersas pela diferentes áreas da empresas, passaram a se integrar. Como mostra a Figura 14:

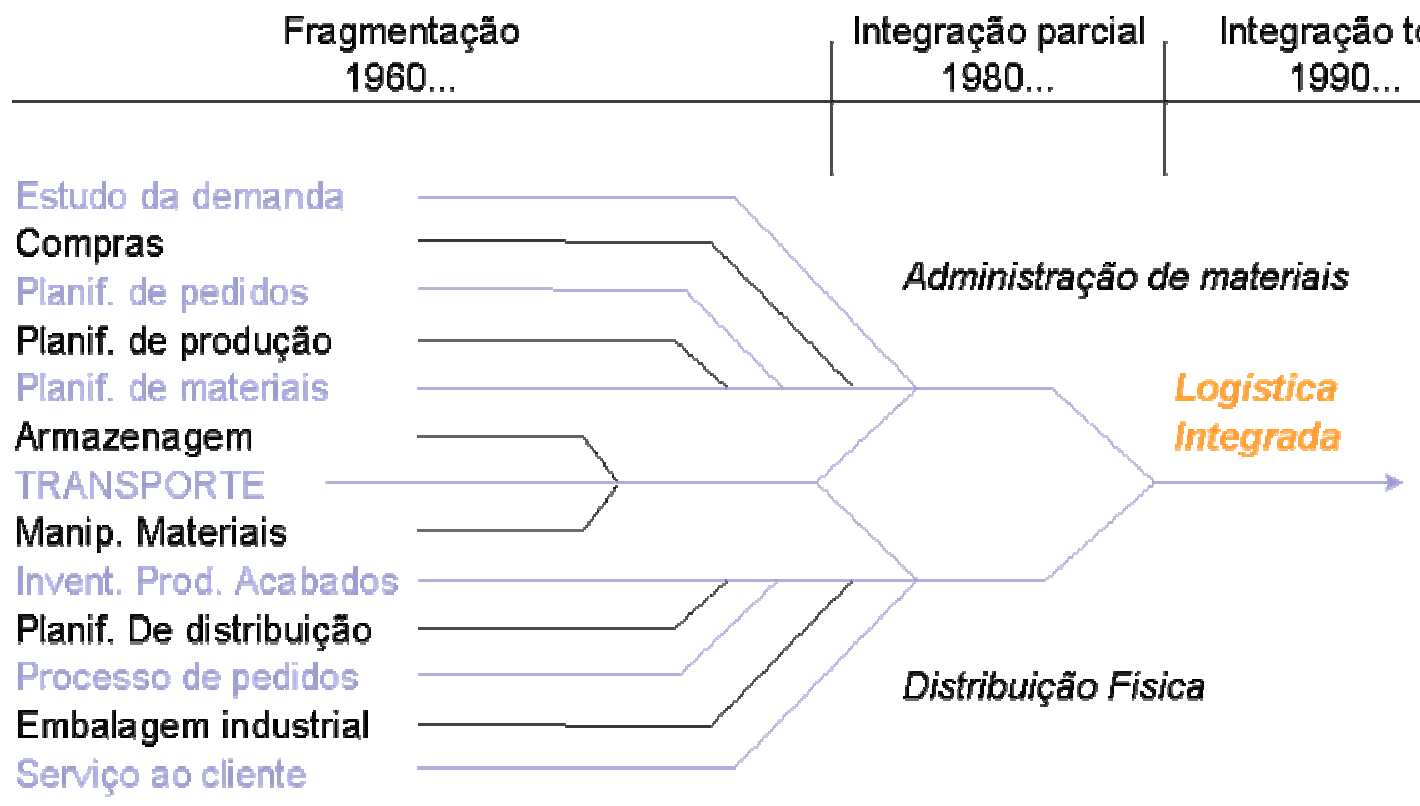

Figura 14: Evolução da logística a partir de 1960 Fonte: Ching (1999)

Ching (1999) ressalta que a mera visão em relação aos estoques não é suficiente para obter vantagem competitiva. Para isso, as empresas terão que rever seus conceitos com relação à logística tradicional e adotar o novo conceito de logística integrada - da era do Supply Chain -, que tem a intenção de promover o fluxo contínuo de entrada de matéria-prima (suprimento), de fabricação do bem (produção) e da saída do produto acabado até o ponto de venda (distribuição).

Neste sentido, Novaes (2001) aborda a evolução da logística por uma perspectiva de integração com relação à cadeia produtiva. A primeira fase, de atuação segmentada, tem o estoque como elemento chave no balanceamento da cadeia de suprimentos. A segunda fase tem a otimização das atividades e planejamento, como elementos chave. Mensalmente, os centros de distribuição da indústria consultavam os 
varejistas, seus clientes, e faziam previsões de demanda. Essas previsões eram encaminhadas à sede, que compatibilizava as previsões e as encaminhava à manufatura. Esta última elaborava o planejamento da produção e transmitia ao setor de compras as necessidades de matéria-prima e de componentes referentes ao mês seguinte. Os fornecedores recebiam as previsões de compras, planejava-se a alocação de mão-deobra para o mês, e assim por diante.

$\mathrm{Na}$ terceira fase, ocorre a integração dinâmica e flexível entre os componentes da cadeia de suprimento, em dois níveis: dentro da empresa e nas inter-relações da empresa com seus fornecedores e clientes. O desenvolvimento da informática possibilitou uma integração dinâmica, de conseqüências importantes na agilização da cadeia de suprimentos, como por exemplo, o intercâmbio de informações entre dois elementos da cadeia de suprimento, que passou a se dar por via eletrônica, através do eletronic data interchange (EDI).

$\mathrm{Na}$ quarta fase, as empresas da cadeia de suprimento passam a tratar a questão logística de forma estratégica, ou seja, em lugar de otimizar pontualmente as operações, focalizando os procedimentos logísticos como meros geradores de custo, as empresas participantes da cadeia de suprimento passaram a buscar soluções novas, usando a logística para ganhar competitividade e para induzir novos negócios. Os agentes da cadeia de suprimento passaram a trabalhar mais próximos, trocando informações antes consideradas confidenciais e formando parcerias. Surge o conceito de logística reversa e a ênfase absoluta na satisfação do consumidor final através da formação de parcerias entre fornecedores e clientes ao longo da cadeia de suprimentos e aplicação de esforços de forma sistemática e continuada, visando agregar o máximo de valor para o consumidor final e eliminar os desperdícios, reduzindo custos e aumentando a eficiência.

A visão de administração da cadeia de suprimentos está associada a um conjunto de fluxos físicos e de informações entre a empresa e seus parceiros, fornecedores e clientes, gerenciados sob o princípio da busca e sustentação da vantagem competitiva pelas organizações envolvidas. Fleury, Wanke e Figueiredo (2000, p.39) complementa ainda que:

[...] o conceito de Supply Chain Management é muito mais do que uma simples extensão da Logística Integrada, pois inclui um conjunto de processos de negócios que, em muito ultrapassa as atividades diretamente relacionadas com a Logística, além disso, existe uma clara e definitiva necessidade de integração das operações na cadeia de suprimentos. 
Segundo Council of Supply Chain Management Professionals (2005):

A gerência da cadeia de suprimentos abrange o planejamento e a
gerência de todas as atividades envolvidas no abastecimento e a
obtenção, a conversão, e todas as atividades da gerência da logística.
De forma importante, inclui também a coordenação e a colaboração
com sócios de mesmos canais, que podem ser fornecedores,
intermediários, fornecedores de serviço terceirizado, e clientes.
Essencialmente, o gerenciamento da cadeia de suprimentos integra
fornecimento e demanda dentro e através das companhias.

Ao fim desta seção, apesar de todos os sinais apontarem o próximo tópico para cadeia de suprimentos, decidiu-se passar ao enfoque contábil decorrente de suas atividades, o que leva luz à questão dos custos logísticos abordados neste trabalho.

\subsection{Custos logísticos}

A teoria da contabilidade separa custos de despesas, apesar de ambos serem gastos. Custos são gastos relacionados aos sacrifícios ocorridos nos processos produtivos e despesas são gastos necessários para se obter receitas. Martins (2001) comenta que empresas de serviços passaram a usar os princípios e técnicas de contabilidade de custos tratando gastos como custos. Devido ao caráter de prestação de serviços que as atividades logísticas possuem, os recursos consumidos pela logística podem ser tratados como custos.

De acordo ao Institute of Management Accountants - IMA (1992), custos logísticos são “[...] os custos de planejar, implementar e controlar todo o inventário de entrada (inbound), em processo e de saída (outbound), desde o ponto de origem até o ponto de consumo".

O gerenciamento, controle e minimização dos custos logísticos têm se mostrado cada vez mais necessários, caso queira a empresa competir no mercado. E um dos principais desafios da logística moderna, conforme Lima (1999) é conseguir gerenciar a relação entre custos e nível de serviço. Isso se deve ao fato de que dia após dia os clientes têm exigido melhores níveis de serviço, sem, contudo, querer pagar mais por isso.

Lima (1999) enfatiza que os seguintes serviços agregam valor dependendo da característica de cada cliente: 
- $\quad$ redução no prazo de entrega de um produto;

- $\quad$ disponibilidade de produtos;

- $\quad$ confiabilidade na entrega (tempo, $\mathrm{n}^{\mathrm{o}}$. de entrega);

- $\quad$ entrega de pedido na hora certa;

- $\quad$ maior facilidade de colocação do pedido.

Para atender a todas estas exigências dos clientes e manter-se competitivas no mercado, as empresas têm, cada vez mais, segmentado seus canais de distribuição e atendimento. Esta posição de segmentar gera nos gerentes logísticos uma série de dúvidas sobre a rentabilidade frente à estratégia, e os impactos que esta melhoria pode causar no custo do nível de serviço oferecido, Lima (1999).

Quanto mais alto for o nível de serviço oferecido pela logística, mais os custos logísticos aumentarão, com taxas crescentes em proporção à melhoria do nível de serviço oferecido.

Conforme o custo logístico aumenta, a necessidade de identificar esses valores torna-se cada vez mais crítica. Como a função logística vem se desenvolvendo bastante nos últimos anos, a proporção de seus custos dentro do total dos custos da empresa também vem aumentando. Assim, conforme Lambert, Stock e Vantine (1998, p. 587):

[...] a contabilidade deve ser capaz de fornecer informações que possam auxiliar os decisores logísticos e ajuda-los a solucionar as seguintes questões:

- Como os custos logísticos afetam a contribuição por produto, por território, por cliente e por vendedor?

- Quais os custos que se relacionam com o aumento do nível de serviço ao cliente? Quais benefícios e perdas que eles proporcionam, e quais trocas compensatórias são necessárias?

- Qual a quantidade ótima de estoque? Qual a sensibilidade do nível de estoque quanto às mudanças nos padrões de armazenagem ou às mudanças nos níveis de serviço a clientes? Qual o custo de manutenção de estoque?

- Qual o conjunto de modal que deve ser utilizado?

- Qual a quantidade e a localização de armazéns/depósitos a serem utilizados?

- Quais tipos de embalagens devem ser utilizados? 
- Quantas paradas na produção são necessárias? Quais fábricas são usadas na fabricação de certo produto? Quais são as capacidades ideais das fábricas para compostos e volumes de produtos alternativos?

- O sistema de processamento de pedido deve ser automatizado? Até que ponto?

- Quais centros de distribuição devem ser utilizados? [...]

Muitos são os custos incorridos ao longo de toda a cadeia logística: custos de suprimento, gestão de fornecedores, de estoques, armazenamento, manutenção, aquisição, transporte, distribuição, falta de estoques, qualidade e confiabilidade, inspeção, informação e de documentação. É freqüente administrar estes custos como se fosse um único sistema, agrupando-os em grandes categorias agregadas. Essa prática dos sistemas tradicionais de custeio não permite identificar os verdadeiros custos dos serviços em relação a um produto demandado por um cliente em particular.

A contabilidade tradicional rateia estes custos de uma forma mais ou menos arbitrária, distorcendo a rentabilidade tanto de clientes como de produtos. Isto ocorre porque o sistema de contabilidade tradicional agrupa os custos em categorias amplas agregadas, o que não possibilita uma análise mais detalhada dos custos incorridos na prestação de serviço ao cliente. Neste sentido, Christopher (1997, p.57) afirma “[...] provavelmente, a falta de informações sobre custos é um dos motivos mais importantes para a dificuldade que muitas companhias têm sentido para a adoção de uma abordagem integrada para a logística e para o gerenciamento da distribuição [...]”.

A administração integrada de custos logísticos pressupõe trade-offs, ou seja, custos individuais não otimizados para permitir a redução do custo total. Para se calcular o custo total, faz-se necessário distinguir claramente quais são seus custos integrantes, os custos das operações da logística de distribuição e os custos resultantes das políticas e condições existentes, temas que serão abordados nos próximos tópicos.

\subsection{Custos de operações da logística de distribuição}

\subsubsection{Custos de embalagens e movimentação}

Conforme Bowersox e Closs (2001), tal elemento de custo, geralmente, é classificado em dois grupos: a embalagem industrial, com ênfase na logística, e a embalagem para o consumidor, com ênfase em marketing. De acordo com Gurgel 
(2000), as embalagens industriais podem ser agregadas em um múltiplo, formando uma embalagem de movimentação ou um módulo de movimentação. As embalagens e os dispositivos de movimentação (pallets, racks, etc.) têm como principais objetivos facilitar o manuseio e a movimentação, bem como a armazenagem, garantir a utilização adequada do equipamento de transporte, proteger o produto, promover a venda do produto, facilitar o uso do produto e prover reutilização para o consumidor.

Para o fabricante, os custos de embalagens e dispositivos de movimentação abrangem depreciação de equipamentos, impostos, margem de lucro embutida no preço, além de mão-de-obra, custos de pesquisa e desenvolvimento e matérias-primas, tais como madeira, papelão, plástico, aço, ferro, etc. Geralmente, tais custos são incorporados ao estoque de matéria-prima, quando associados à obtenção de materiais na logística de abastecimento, e podem ser considerados custos indiretos de fabricação, quando associados às operações da logística de planta, ou custos de distribuição. Estes podem ser considerados custos variáveis nas cadeias de abastecimento, pois dependem do volume movimentado. Podem também ser considerados como custos diretos aos objetos de custeio a serem analisados (cadeia, cliente ou canal de distribuição), quando for possível identificá-los.

Embalagens e dispositivos de movimentação podem ser retornáveis ou de única utilização. Os custos de embalagem, em uma decisão de utilizar embalagens de única utilização, envolvem custos de material, componentes, mão-de-obra e encargos, depreciação e manutenção de equipamentos, os de retornáveis envolvem custos de capital investido, manutenção e administração. A embalagem deve ser analisada e projetada em função de sua movimentação e utilização na cadeia logística e não, como freqüentemente ocorre, condicionando a cadeia aos tipos de embalagem pré-existentes. Significa que, eventualmente, o maior custo de uma embalagem pode resultar em importante redução do custo total da cadeia que a utiliza.

Bowersox e Closs (2001, p.363) destacam que a embalagem influi em todas as atividades logísticas pois (1) o controle de estoque depende da identificação manual ou automatizada que é afixado na embalagem do produto, (2) a embalagem viabiliza a rapidez na separação dos pedidos, (3) o custo de movimentação e manuseio do produto depende da capacidade de unitização e das técnicas adotadas, (4) os custos de transporte e de armazenagem são influenciados pelas dimensões e densidade das unidades embaladas, e (5) a qualidade do serviço ao cliente também depende da embalagem, para manter especificações de qualidade durante a distribuição, e atender às legislações ambientais vigentes. 
Como exemplo tem-se a Figura 15, que evidencia algumas conseqüências e trade-offs de custos de embalagem e tipo de embalamento, movimentação e materiais de uma cadeia de exportação de peças e componentes referentes à indústria automobilística.

\begin{tabular}{|c|c|}
\hline ETAPAS DA CADEIA & CONSEQUENCIAS / TRADE-OFFS \\
\hline 1. Embalamento no País de origem. & 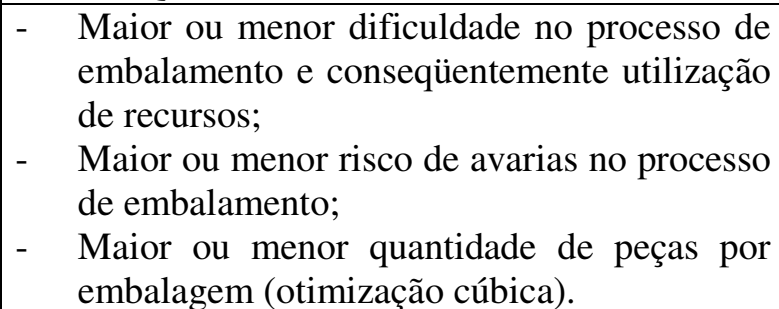 \\
\hline $\begin{array}{l}\text { 2. Movimentação, armazenagem } \\
\text { temporária, conteinerização } \\
\text { carregamentos. }\end{array}$ & \begin{tabular}{|lr} 
- & $\begin{array}{l}\text { Maior ou menor complexidade } \\
\text { movimentação, de }\end{array}$ \\
carregamento com conseqüência nos & nos \\
recursos necessários e custos; & \\
- & $\begin{array}{l}\text { Otimização da utilização de contêineres e/ou } \\
\text { de meios de transportes. }\end{array}$
\end{tabular} \\
\hline $\begin{array}{l}\text { 3. Transporte } \\
\text { Rodoviário até o porto ou } \\
\text { aeroporto } \\
\quad \text { Marítimo ou aéreo. }\end{array}$ & $\begin{array}{l}\text { - } \begin{array}{l}\text { Proteções adequadas das peças, evitando ou } \\
\text { minimizando custos de avarias, quebras, } \\
\text { corrosão, etc.; } \\
\text { - Otimização da utilização no transporte, } \\
\text { acarretando significativas reduções ou } \\
\text { aumentos de custos do transporte por peça } \\
\text { (otimização cúbica no transporte) }\end{array} \\
\end{array}$ \\
\hline $\begin{array}{l}\text { 4. Descarregamento no porto ou aeroporto } \\
\text { e transporte até o destino final. }\end{array}$ & $\begin{array}{ll}- & \text { Riscos de avarias; } \\
- & \text { Custos de transporte até o destino final } \\
\end{array}$ \\
\hline $\begin{array}{l}5 . \quad \text { Recebimento, desconsolidação, } \\
\text { armazenagem temporária e abastecimento } \\
\text { de linhas. }\end{array}$ & $\begin{array}{ll}- & \text { Facilidade ou dificuldade de movimentação; } \\
\text { - } & \text { Idem para desconsolidar cargas; } \\
\text { - } & \text { Área demandada para movimentação e } \\
& \text { armazenagem; } \\
\text { - } & \text { Abastecimento de linha. }\end{array}$ \\
\hline $\begin{array}{l}\text { 6. Reutilização ou disposição final de } \\
\text { embalagens one-way. }\end{array}$ & $\begin{array}{ll}\text { - } & \text { Controle e devolução de embalagens } \\
& \text { retornáveis (quantidade potencial de sua } \\
& \text { reutilização vs custo); } \\
\text { - } & \begin{array}{l}\text { Dificuldades do disposal (poluição, área, } \\
\text { processamento, danos ambientais, etc.) }\end{array}\end{array}$ \\
\hline
\end{tabular}

Figura 15 : Trade-offs entre soluções de embalagens e operações logísticas

Fonte: Carrilo Jr. ${ }^{1}$ (2001 apud Faria, 2003)

\subsubsection{Custos de manuseio de materiais}

Esses custos envolvem, basicamente, custos com pessoal (mão-de-obra operacional e de supervisão), custos de manutenção e depreciação dos equipamentos de

\footnotetext{
${ }^{1}$ CARRILO JR., E. (2001). Seminário de Custos da Logística no Brasil. Apostila... São Paulo: IMAM apud FARIA, A.C. (2003). Uma abordagem na adequação das informações de controladoria à gestão da logística empresarial. 313p. Tese (Doutorado) - Faculdade de Economia, Administração e Contabilidade, Universidade de São Paulo, São Paulo, 2003.
} 
movimentação. Entre outros gastos gerais, normalmente, são incluídos nos custos indiretos de fabricação de uma empresa industrial, tratados também como custos fixos, que podem ser reduzidos pela eliminação de movimentos desnecessários na operação e podem ser acompanhados pelo aumento da rotatividade.

Segundo Freese (1999), os principais trade-offs aparecem, no instante em que se tenta reduzir o número de movimentações de materiais e distâncias (questões de layout), reduzir o espaço e os custos de mão-de-obra e níveis de inventário por tipo de material.

Custos de manuseio e movimentação podem ter alguns tratamentos diferenciados; se os funcionários recebem salários mensalmente e os equipamentos forem da empresa analisada, podem ser considerados custos indiretos e fixos. Se a empresa tiver terceirizado esta atividade de manuseio e movimentação para um operador logístico, por exemplo, poderá tornar-se um custo variável.

\subsubsection{Custos de armazenagem}

Armazenagem é um conjunto de atividades para manter, fisicamente, estoques. Para isso, tais atividades requerem soluções para questões como localização, dimensionamento de área, arranjo físico, alocação dos estoques, projeto de docas e configuração dos armazéns, tecnologia de movimentação interna, estocagem e sistemas.

Para Ballou (2001, p.202), uma empresa utiliza o espaço de armazenagem por quatro razões básicas: reduzir custos de transportes e de produção, coordenar oferta e demanda, auxiliar no processo de produção e ajudar no processo de marketing.

A armazenagem pode ser pública/geral, própria ou terceirizada. Os benefícios que podem ser alcançados por uma empresa que utiliza armazenagem pública/geral em vez da própria, segundo Lambert, Stock e Vantive (1998, p.271), são: conservação do capital, capacidade de aumentar o espaço do armazém para acomodar exigências de pico, menor risco, economias de escala, flexibilidade, vantagens fiscais, conhecimento dos custos de armazenagem e movimentação e minimização de causas trabalhistas.

Custos de armazenagem geral podem ser reduzidos através da redução de tarifas, aluguel de contêineres, planejamento de desova de contêineres e integridade de dados de inventário. Os autores acima citados ainda complementam que, ao se utilizar um armazém público, o fabricante conhece seus custos de armazenagem precisamente pois recebe uma conta mensal. Com isso, podem-se prever custos para níveis diferentes de atividade, já que são conhecidos de antemão. No caso da empresa utilizar armazenagem 
terceirizada é preciso considerar: características de instalação, serviços de armazenagem proporcionados, disponibilidade e proximidade dos terminais de transporte, disponibilidade local de carretas, disponibilidade de tecnologia de informação, bem como o tipo e freqüência de relatórios de estoque.

Os principais trade-offs de custos de armazenagem residem nos custos de manutenção de inventário e custos de transporte, que podem ocorrer em função de decisões estratégicas e estruturais de armazenagem. Existem também os custos de processamento de pedidos, custos de manuseio e movimentação e custos tributários, que também são influenciados pelo número de armazéns de uma rede logística.

Os custos de armazenagem interagem ou são influenciados pelos custos de transporte pois dependem do tipo e modo de movimento. Movimentos de transporte primários, por exemplo, são os transportes da fábrica para armazéns, aumentam com armazéns adicionais, mas podem reduzir custos de transporte de armazéns para clientes. Daí, a necessidade de análise de custo total, focalizada na logística integrada, para balancear todos os custos e necessidades.

$\mathrm{O}$ aumento da quantidade em estoque acarreta um aumento nos custos de armazenagem pois o estoque só poderá ser movimentado com a utilização de mais pessoal ou com o maior uso de equipamentos. Esse é um dos motivos para se ter o mínimo estoque possível, sincronizando a produção com a demanda e aumentando o giro dos estoques, através de carregamentos menores e mais freqüentes.

\subsubsection{Custos de transportes}

O transporte envolve a movimentação de produtos do fornecedor para a empresa, entre plantas e da empresa para o cliente, com produtos em forma de materiais, componentes, subconjuntos, produtos semi-acabados, produtos acabados ou peças de reposição. Existem diferentes maneiras de se realizar o transporte, pelos modais, como meio rodoviário, ferroviário, marítimo, aeroviário e hidroviário. A rapidez e consistência com que um produto se move de um ponto a outro determina a esta atividade um fator de utilidade.

Com o objetivo de obter ganho de eficiência e redução de custos, atualmente, constata-se uma tendência do uso de diferentes modais, transportes intermodais, para um deslocamento mais econômico, considerando o nível de qualidade pretendido. Considerando-se os diferentes modais, nota-se que os preços de transporte são 
inversamente proporcionais aos custos de estoque, ou seja, quanto maior a carga (estoque) menor o custo de transporte.

Harmon (1994) indica transportes como uma função chave para se reduzir, incisivamente, os estoques no fluxo logístico de abastecimento e de distribuição, dependendo do tamanho dos veículos de transporte e da frequiência de viagens entre fornecedor e cliente.

Para Bowersox e Closs (2001), os fatores econômicos de transporte são afetados por sete aspectos específicos: distância, volume, densidade, facilidade de acondicionamento, facilidade de manuseio, responsabilidade e fatores de mercado, tais como intensidade e facilidade de tráfego.

Considerando-se a distribuição, existe predominância de produtos de maior valor e menor volume que no abastecimento, e dependendo do segmento, há maior ênfase nas necessidades de serviço ao cliente em relação às perdas ou prejuízos, tempo de entrega, embalagem, etc. Esses fatores afetam as decisões de seleção do modal, tamanho da carga, usa de frota própria, etc.

Caso a empresa possua frota própria, terá de gerir alguns custos associados. Podem ser considerados custos fixos: depreciação, remuneração do capital sobre os investimentos em ativos imobilizados, salário do pessoal (motoristas, etc.), custos administrativos, seguro do veículo, IPVA, seguro obrigatório, manutenções, etc. São considerados custos variáveis: pneus, combustíveis, lavagens e pedágios, em função dos trajetos a ser percorridos. O pedágio não deve ser alocado de acordo com a quilometragem, como os demais, devendo ser considerado conforme cada rota (podendo ser considerado um custo direto ao objeto de custeio rota).

A classificação entre fixo e variável depende tanto da operação da empresa como da ocorrência do fator gerador. Por exemplo, se o motorista tiver rendimento mensal, esse custo será fixo, se esse profissional for remunerado por quilometragem, o custo passará a ser variável.

Num sistema logístico, os embarques podem ser roteirizados e agendados, no intuito de gerar economias de escala, e isso envolve decisões de transporte associadas à consolidação do transporte. Pode-se roteirizar veículos, criando um pool com vários embarques, utilizando intermodadalidade ou estruturando tabelas de embarques que podem ser ajustadas a outros embarques. Criando um programa de consolidação de transportes, uma empresa pode beneficiar-se de economias de escala significativas, maior competitividade e redução dos custos, caso esteja integrada a um sistema eficiente de processamento de pedidos. 
Na busca da redução de custos de transporte, podem-se aumentar custos de armazenagem, de manutenção de inventário e de tecnologia de informação, que podem superar a economia feita no transporte. Ou ainda, dependendo do modal escolhido, pode-se ter um transporte mais lento, utilizando-se trem em vez de avião, por exemplo. Conseqüentemente, o giro do capital será mais lento tornando o capital investido no sistema logístico "engessado", ou seja, imobilizado até o pagamento que, por sua vez, dependerá do recebimento da venda dos produtos/serviços.

Gattorna e Walters (1996, p.141) comentam algumas possibilidades de trade-offs nas decisões de transportes:

- horizontais - ocorrem dentro e entre os diferentes modos de transportes, que podem ser selecionados para a mesma tarefa, assim como aéreo versus marítimo;

- $\quad$ verticais - verificam-se quando uma mudança acontece toma lugar em uma atividade de transporte e oferece um grande benefício em outra área, como uma melhoria na produtividade, observada no desenvolvimento da infraestrutura, por exemplo, a construção de uma nova rodovia e

- $\quad$ laterais - ocorrem onde custos de transporte podem ser aumentados, sendo compensados por menores custos em outros elementos de custos. Por exemplo, usar um frete aéreo pode aumentar o custo com frete, mas pode reduzir a necessidade de um centro de distribuição (custo de armazenagem) ou altos custos de manutenção de inventário.

Assim, após estabelecidos os custos operacionais da logística de distribuição, faz-se necessário esclarecer os custos resultantes das políticas de atendimento dos pedidos e das condições impostas à logística de distribuição.

\subsection{Custos resultantes das políticas e condições existentes}

De acordo com Costa (2003) pode-se dividir essa categoria de custos em três subgrupos: custos resultantes do nível de serviço, custos relativos ao lote e custos do nível de inventário. Tais categorias serão abordadas nos tópicos seguintes. 


\subsubsection{Custos resultantes do nível de serviço}

Para Ballou (1993, p. 73):

Nível de serviço logístico é a qualidade com que o fluxo de bens ou serviços é gerenciada. É o resultado líquido de todos os esforços logísticos da firma. É o desempenho oferecido pelos fornecedores aos seus clientes no atendimento dos pedidos. O nível de serviço logístico é o fator chave do conjunto de valores logísticos que as empresas oferecem a seus clientes para assegurar sua fidelidade. Como o nível de serviço logístico está associado aos custos de prover esse serviço, o planejamento da movimentação de bens e serviços deve iniciar-se com as necessidades de desempenho dos clientes no atendimento de seus pedidos.

De acordo com Bowersox e Closs (2001) o serviço ao cliente pode ser mensurado em termos da disponibilidade de materiais, desempenho operacional e confiabilidade. Nesse sentido, a disponibilidade relaciona-se com a manutenção de estoques para o pronto atendimento das necessidades dos clientes. O desempenho operacional refere-se ao tempo incorrido desde a colocação do pedido da mercadoria até a entrega da mesma ao consumidor final, enquanto a confiabilidade mede a pontualidade das entregas, isto é, o efetivo cumprimento dos prazos de entregas previamente acordados com os clientes.

Assim, pode-se interpretar o nível de serviço como um conjunto de opções logísticas que a empresa oferece para cada cliente, no intuito de atender suas necessidades e exigências frente aos custos associados, de modo a maximizar os lucros, como ilustra a Figura 16. É Interessante ressaltar a idéia de segmentação dos clientes pois ser competitivo não implica necessariamente, oferecer altos níveis de serviço indiscriminadamente, já que nem todos os clientes valorizam todos os serviços oferecidos.

Hijjar (2000) defende que existem duas vias para segmentação de clientes, baseadas na apuração de necessidades e expectativas semelhantes: a posteriori, primeiro agrupam-se os clientes de acordo com características facilmente identificáveis (informações demográficas, geográficas, com base em seus comportamentos de compra, etc.), para depois verificar suas necessidades e expectativas e, a priori, primeiramente identificam-se as necessidades e expectativas dos clientes para depois alocá-los em grupos e então criar pacotes de serviço para cada grupo. 


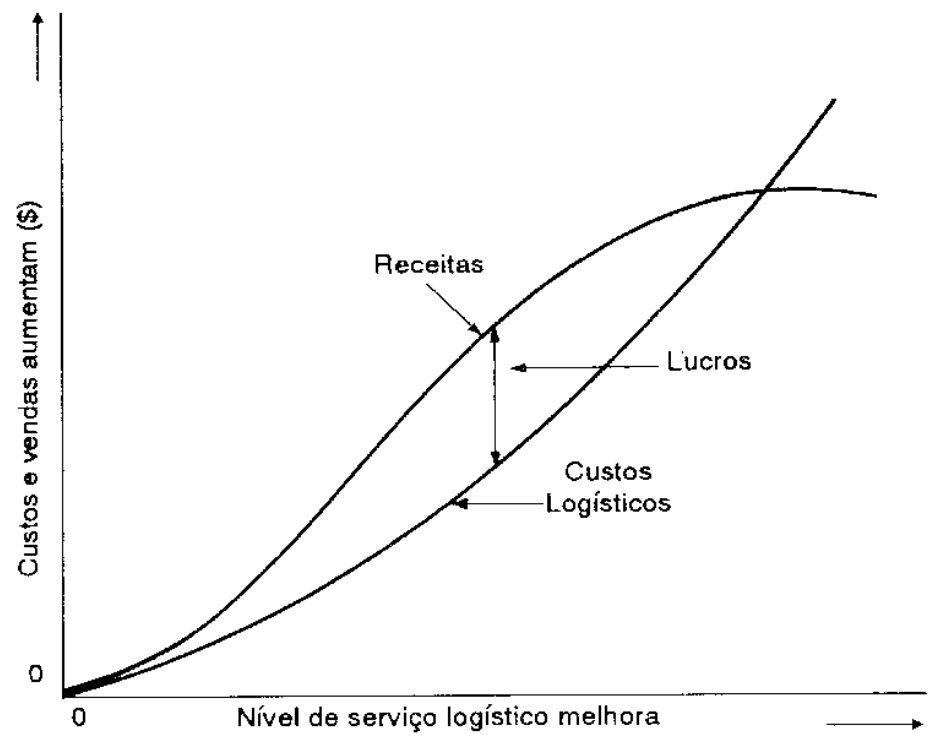

Figura 16 : Compensação generalizada entre receitas e custo para diversos níveis de serviço logístico

Fonte: Ballou (1993)

Do ponto de vista logístico, existem diversos fatores ou elementos que influenciam o nível de serviço oferecido ao cliente e, de um modo geral, pode-se dividilos, de acordo com Ballou (1993), em três grupos: elementos pré-transação, transação e pós-transação, como demonstra Figura 17. Os elementos pré-transação prescrevem um ambiente para bons níveis de serviço, expressamente escrito numa política de nível de serviço, tornando claro ao cliente o que pode esperar do serviço oferecido. Elementos de transação fazem parte dos resultados diretos em relação à entrega do produto ao cliente, como: níveis de estoque, modal e processamento do pedido. Estes elementos coordenam tempos de entrega, preenchimento correto de pedidos e disponibilidade de estoques. Por fim, elementos pós-transação incluem serviços que garantem o bom funcionamento do produto e a satisfação do cliente com isso.

Referenciando o autor supracitado, muitos destes elementos podem ser identificados pelo acompanhamento de um pedido ou ordem em diferentes fases, ou seja, através do ciclo do pedido. Conforme ilustra Figura 17. 


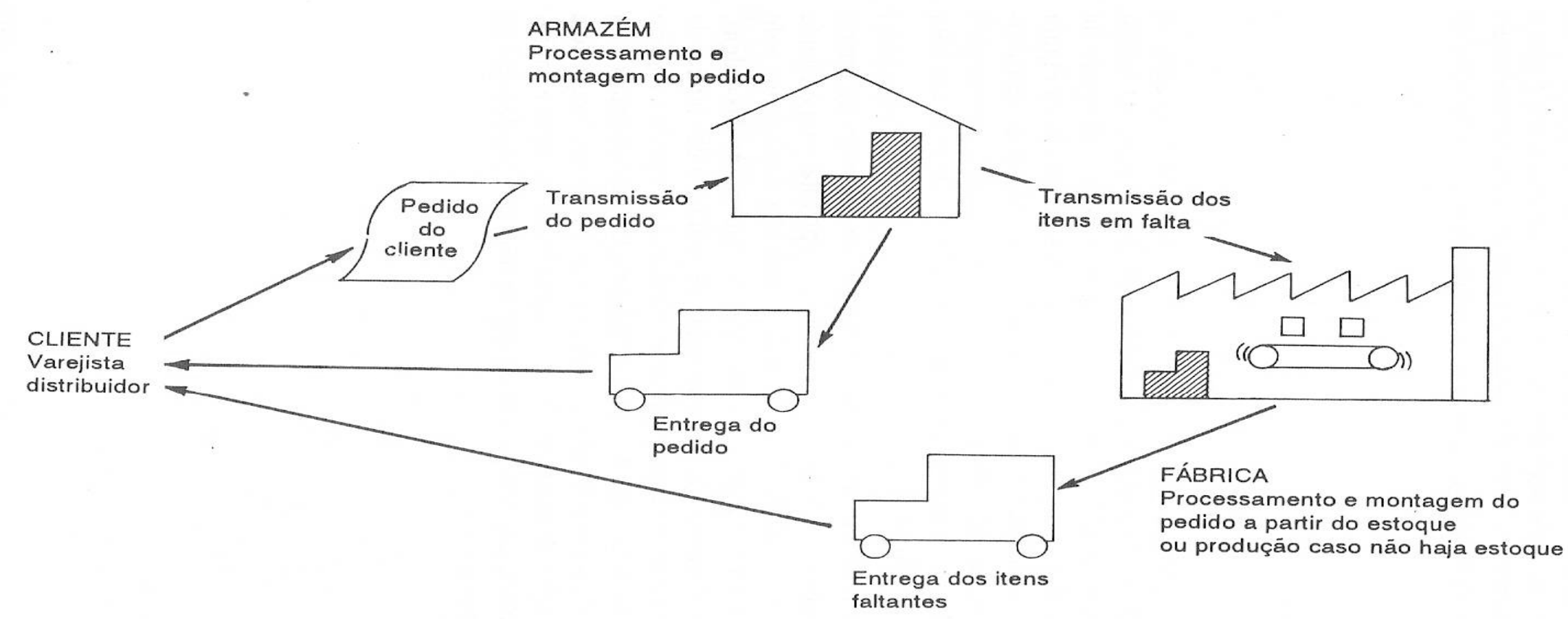

Tempo total do ciclo de pedido

$\left|\longleftarrow \begin{array}{c}\text { Transmissão } \\ \text { do pedido }\end{array}\right| \begin{gathered}\text { Processamento e } \\ \text { montagem do }\end{gathered} \mid<\quad \begin{gathered}\text { Tempo para aquisiçäo } \\ \text { de estoque adicional }\end{gathered}$

montagem do

Tempo de entrega

$\rightarrow$

a. Consolidação do pedido

b. Transmissäo do pedido ao depósito

a. Preparação do manifesto

b. Liberaçäo do crédito

c. Montagem do pedido no depósito a. Se item em falta tempo adicional para conseguir estoque da fábrica a. Tempo de entrega a partir do depósito

b. Tempo de entrega a parti da fábrica

Figura 17: Componentes de um ciclo de pedido.

Fonte: Ballou (1993) 
Apesar das empresas criarem diversos tipos de medidas acerca do nível de serviço (disponibilidade de estoque, porcentagem de ordens preenchidas, porcentagem de itens em falta, porcentagem das ordens entregues dentro de certo prazo após recebimento do pedido), os fatores chaves são a velocidade e a confiabilidade do atendimento do pedido que influenciam diretamente no tempo de ciclo do pedido.

A fixação de uma política de serviço decorre da declaração formal e escrita sobre como o fornecedor pretende agir em relação ao serviço. Segundo Ballou (1993) políticas sobre nível de serviço podem ser simples: "todas as ordens recebidas até meiodia serão despachadas no mesmo dia", ou elaboradas cobrindo em detalhes fatores como: tempo, confiabilidade, condição de mercadorias, conveniência de colocação de pedidos e comunicação de ordens. Podem ser declaradas em separado ou dentro de colocações mais amplas da empresa sobre como os clientes são tratados.

\subsubsection{Custos do nível de inventário}

Em adição ao item 3.4.3, aborda-se esta categoria de custos com diferente foco da logística operacional, abrangendo aspectos complementares.

O inventário representa a maior parcela de investimento em ativos para algumas empresas. Stock e Lambert (2001) fornecem dados auspiciosos: em companhias de manufatura, o investimento em inventário representa, tipicamente, $10 \%$ ou mais do total de ativos e em alguns casos pode exceder $20 \%$ do total. Para distribuidores e varejistas, o investimento em inventário, usualmente, é maior que $20 \%$ e pode chegar a $50 \%$. Esses valores representam grande montante de capital parado, que poderia estar sendo investido e altos custos para manter os estoques influindo diretamente no retorno sobre patrimônio líquido da empresa.

Além disso,

Os gerentes precisam conhecer os custos de inventário para manter informadas decisões sobre projeto do sistema logístico, nível de serviço ao consumidor, o número e locais de centros de distribuição, níveis de inventário, acumulação de inventário, modais de transporte, programação da produção, e o mínimo de corridas de produção. (STOCK e LAMBERT, 2001, p.188).

Devido ao impacto direto no nível de serviço oferecido, as políticas em relação ao giro e nível de estoque devem ser guiadas por informações precisas sobre os custos 
de inventário, assim como decisões relacionadas ao tamanho do lote de produção, tamanho de ordens e descontos de venda.

Os autores supracitados defendem que cada empresa deveria determinar seus próprios custos logísticos e lutar para minimizar o total destes custos, dados seus objetivos de serviço ao cliente. Os custos de inventário deveriam incluir apenas aqueles que variam com a quantidade de inventário, e podem ser categorizados em: (1) custos de capital, (2) custos de impostos e seguros, (3) custos de espaço de armazenagem (já abordados) e (4) custos de riscos de estoques.

Como foi dito anteriormente, estoque significa dinheiro parado, logo uma empresa deveria utilizar análise de projetos de investimento para questões de aumento ou diminuição de estoque. $\mathrm{O}$ risco e a taxa de retorno de se manter determinada quantia de estoque frente às possibilidades de investimento deveriam guiar decisões acerca de estoque. $\mathrm{Na}$ análise de valor de estoque, deveriam excluir os custos fixos de produção (overhead) dos valores de inventário, de modo a refletir o custo de reposição, que seriam os custos de aquisição de materiais e mão-de-obra direta.

Custos de impostos e seguros incluem taxas de propriedade, seguro contra incêndios e roubo. Em geral, tais taxas variam com o nível de estoque, e no caso do seguro envolvem o valor da mercadoria estocada e as características físicas do local onde se estoca, como idade do prédio e sistema contra-incêndio.

Por fim, custos de riscos de estoques, de acordo com Stock e Lambert (2001), apesar de variarem de acordo a empresa, tipicamente, incluem:

- obsolescência - o custo de cada unidade a ser descartada por não poder ser vendida a um preço normal. Representa a diferença entre o custo original da unidade e seu valor residual, ou a diferença entre o preço de venda original e o preço de venda reduzido, caso o preço seja baixado para escoar o produto;

- avaria - esta subcategoria de custos deveria ser incluída somente para a parte da avaria que oscila de acordo com o volume dos estoques. Caso a avaria ocorra durante o transporte, deve ser considerada custo de processamento. Avarias atribuídas a um armazém público são usualmente cobradas do operador do armazém, se ultrapassarem um máximo especificado;

- perdas - os custos de perdas podem estar mais relacionados com medidas de segurança do que com os níveis de estoque, ainda que variem 
definitivamente com o número de armazéns. As perdas variam também de acordo com o ramo de atividade, porém a segurança é um problema central tanto no gerenciamento de materiais quanto no transporte. Em outros casos, as perdas podem ser resultado de controles deficientes ou da expedição de produtos ou quantidades erradas aos clientes;

- realocação - incorrem quando os estoques são transferidos de um armazém para outro para evitar a obsolescência. Tais transferências para evitar obsolescência ou redução de preços são resultado de excesso de inventário. Esse custo deveria ser incluso nos custos de se manter o estoque e não como parte integrante dos custos de transporte.

Depois de apresentar os custos logísticos de distribuição, numa visão intra fábrica, voltar-se-á ao adiado, mas não esquecido tema da cadeia de suprimentos.

\subsection{Enxergando a cadeia de suprimentos}

A visão deste trabalho sobre cadeia de suprimentos apoiar-se-á no manual Enxergando o Todo, de Womack e Jones (2004), que estende o mapeamento do fluxo de valor da fábrica para a cadeia de suprimentos. A escala dos mapas muda significativamente entre o Aprendendo a Enxergar (mapas no nível da planta) e o Enxergando o Todo. As caixas que representam as plantas são as unidades primárias de análise neste manual e têm o mesmo tamanho das caixas que representam os processos individuais no Aprendendo a Enxergar. Todo o raciocínio funda-se no fluxo de valor estendido, no intuito de reduzir os custos, melhorar o tempo de resposta e a qualidade.

Um fluxo de valor estendido é simplesmente toda ação (agregando valor ou não) para levar um produto, desde a matéria-prima, até os braços dos consumidores. Seu objetivo mor é conscientizar o pensamento coletivo a respeito do desperdício, além de identificar oportunidades sistemáticas para sua eliminação. As ações relevantes a ser mapeadas abraçam dois fluxos: (a) pedidos fluxo acima, partindo do cliente em direção ao fornecedor (ou do departamento comercial onde previsões são substituídas por pedidos confirmados) e (b) produtos fluxos abaixo, ou seja, da matéria-prima em direção ao cliente. Juntos, estes constituem um circuito fechado de demanda e resposta. 
Basicamente, os mapas de fluxo de valor representam uma ferramenta gráfica, de linguagem uníssona ao longo da cadeia de suprimentos, para descrever seu estado atual, progredindo através de dois "estados futuros" para um "estado ideal" que objetiva eliminar o desperdício, no decurso de um plano de ação para implementação.

Argumentam Womack e Jones (2004, p. 10):

Acreditamos que o foco preciso na melhoria de cada fluxo de valor, e não a concordância estratégica sobre os princípios, foi o que deu à Toyota as condições para a criação da base de fornecimento mais enxuta do mundo.

No manual, os autores restringem o campo de visão, começando pelo centro de distribuição para o produto acabado e prosseguindo fluxo acima, até as matérias-primas. A visão inicial foca uma família de produtos, ou seja, vários itens que passam pelas mesmas etapas de processamento e utilizam os mesmos equipamentos, antes do embarque para o cliente final. Assim como no custeio baseado em atividades, os autores instruem mapear todas as ações realizadas sobre o produto, todas as ações de gerenciamento da informação e o tempo requerido. Note-se o termo ações, diferente, porém equiparado a atividades.

Seguem, como exemplo de uma família de produtos, limpadores de párabrisas. Listam todas as ações enumerando-as e dividindo-as entre as que agregam e as que não agregam valor. Registram o tempo total decorrido, que contém o tempo exigido para a condução de todas as etapas de produção, e comparam ao tempo real de valor agregado, que é a soma das etapas que agregam valor. As Figura 18 e 19 representam o exemplo.

Finalmente, fornecem auspiciosa definição para as ações que agregam e as que não agregam valor, ou seja, a diferença entre valor e desperdício.

"Na verdade, isso é muito simples. Basta colocar-se no lugar do cliente, imaginando se você pagaria menos pelo produto ou se ficaria insatisfeito com ele caso uma determinada etapa fosse deixada de lado". (WOMACK e JONES, 2004, p. 18).

Auspiciosa a definição pois atividades de recebimento, armazenamento, expedição e transporte não agregariam valor, portanto, deveriam ser eliminadas. Ressalte-se que os autores mapeiam do centro de distribuição até as matérias-primas.

À medida que valor na logística de distribuição (do centro de distribuição ao cliente) se materializa em produtos entregues rigorosamente em conformidade com o especificado, no prazo estabelecido, sem avarias, no local e horário pré-determinados, 


\begin{tabular}{|c|c|c|c|}
\hline Etapas & $\begin{array}{l}\text { Etapas que } \\
\text { agregam } \\
\text { valor }\end{array}$ & $\begin{array}{l}\text { Tempo } \\
\text { Total }\end{array}$ & $\begin{array}{l}\text { Tempo de } \\
\text { agregação } \\
\text { de valor }\end{array}$ \\
\hline \multicolumn{4}{|l|}{$\begin{array}{l}\text { Fornecedor de matéria-prima: } \\
\text { Aços Michigan, Dearbon Heights, Michigan }\end{array}$} \\
\hline $\begin{array}{l}\text { 1. Carregamento e expedição de bobinas duas vezes } \\
\text { por semana }\end{array}$ & & $10 \mathrm{mn}$ & \\
\hline Conexão de transporte 1 & & $8 \mathrm{~h}$ & \\
\hline $\begin{array}{l}\text { 2. Transporte direto (caminhão), Tonawanda, New } \\
\text { York (500 milhas) }\end{array}$ & & & \\
\hline \multicolumn{4}{|l|}{$\begin{array}{l}\text { Fornecedor de segundo nível: } \\
\text { Estamparia Gama, Tonawanda, Nova York }\end{array}$} \\
\hline 3. Descarregamento das bobinas & & $10 \mathrm{~min}$ & \\
\hline 4. Recebimento e emissão de documentação & & $10 \mathrm{~min}$ & \\
\hline 5. Armazenamento das bobinas & & 14 dias & \\
\hline 6. Transporte das bobinas para a prensa 1 & & $10 \mathrm{~min}$ & \\
\hline 7. Preparação da bobina e alimentação da prensa & & $5 \mathrm{~min}$ & \\
\hline 8. Estampagem da forma inicial (plana) & 1 & $1 \mathrm{~s}$ & $1 \mathrm{~s}$ \\
\hline $\begin{array}{l}\text { 9. Espera para formação do lote de peças } \\
\text { estampadas }\end{array}$ & & $4 \mathrm{~h}$ & \\
\hline 10. Transporte das peças estampadas para o depósito & & $10 \mathrm{~min}$ & \\
\hline 11. Armazenamento das peças & & $48 \mathrm{~h}$ & \\
\hline 12. Transporte das peças estampadas para prensa 2 & & $10 \mathrm{~min}$ & \\
\hline $\begin{array}{l}\text { 13. Carregamento das peças para auto-alimentação } \\
\text { da prensa }\end{array}$ & & $10 \mathrm{~min}$ & \\
\hline 14. Estampagem da forma final (curva) & 2 & $10 \mathrm{~s}$ & $10 \mathrm{~s}$ \\
\hline . & . & . & . \\
\hline \multicolumn{4}{|l|}{ Conexão de transporte 2} \\
\hline $\begin{array}{l}\text { 24. Transporte direto de caminhão a Harlingen, } \\
\text { Texas (1500 milhas) }\end{array}$ & & $96 \mathrm{~h}$ & \\
\hline$\cdot$ & $\cdot$ & $\cdot$ & . \\
\hline \multicolumn{4}{|l|}{ Conexão de transporte 7} \\
\hline $\begin{array}{l}\text { 73. Expedição para o Centro de Distribuição de } \\
\text { Cleveland, via trem (500 milhas) }\end{array}$ & & $12 \mathrm{~h}$ & \\
\hline
\end{tabular}

Figura 18 : Etapas físicas necessárias para criar um limpador de pára-brisa Fonte: Womack e Jones (2004) 


\begin{tabular}{c|c|c|}
\multicolumn{1}{c}{} & \multicolumn{1}{c}{ Total } & \multicolumn{1}{c}{$\begin{array}{c}\text { Agregação } \\
\text { de valor }\end{array}$} \\
\cline { 2 - 3 } Etapas & 73 & 8 \\
\cline { 2 - 3 } Tempo & 44,3 dias & 54,7 min. \\
\cline { 2 - 3 } & &
\end{tabular}

Distância 5.300 Milhas em 7 Conexões de Transporte

Figura 19 : Resumo das etapas físicas

Fonte: Womack e Jones (2004)

em condições que facilitem manuseio e estocagem, ou, se for o caso, assistindo o cliente na instalação e uso do produto, seria leviano considerar as atividades acima citadas como desperdício. Obviamente, quanto mais rápidas e menos custosas mais benefícios serão percebidos pelos clientes. Desperdício soa inexato.

Considerações à parte, continuam os autores, em seu manual, a descrever a ferramenta de mapeamento de fluxo de valor estendido. Para isso introduzem dois ícones inauditos aos do Aprendendo a Enxergar.

Um é o ícone de cross-dock para onde os produtos não são armazenados; são transportados imediatamente de um veículo que chega a outro que parte. O outro é um ícone de depósito para as instalações onde os produtos que chegam são selecionados e armazenados antes de serem expedidos ao seu próximo destino. (WOMACK e JONES, 2004, p. 21)

De mais a mais, acrescentam:

Logo você descobrirá que não é possível conseguir as informações necessárias para melhoria do fluxo de valor sem desenhar mapas detalhados do estado atual das plantas isoladamente. Por isso é que o domínio dos conceitos apresentados no Aprendendo a Enxergar é um pré-requisito para o macro-mapeamento. (WOMACK e JONES, 2004, p. 22).

Fica clara a necessidade de que os mapas das plantas isoladas sejam anexados ao macro-mapa. Neste, cada planta é representada por um ícone e por uma caixa de dados, abaixo contendo dados a respeito dos estoques (matérias-primas, estoque em processo e produtos acabados), quantidade de tempo produtivo (número de turnos por dia e número de dias de trabalho por semana), freqüência do ciclo de produção (mostrando com que freqüência cada peça é fabricada, como "tpt=1 dia", significando "toda peça todo dia") e nível de defeitos (em peças por milhão), conforme relatado pelo cliente da planta seguinte do fluxo, que pode ser visto na Figura 20. 


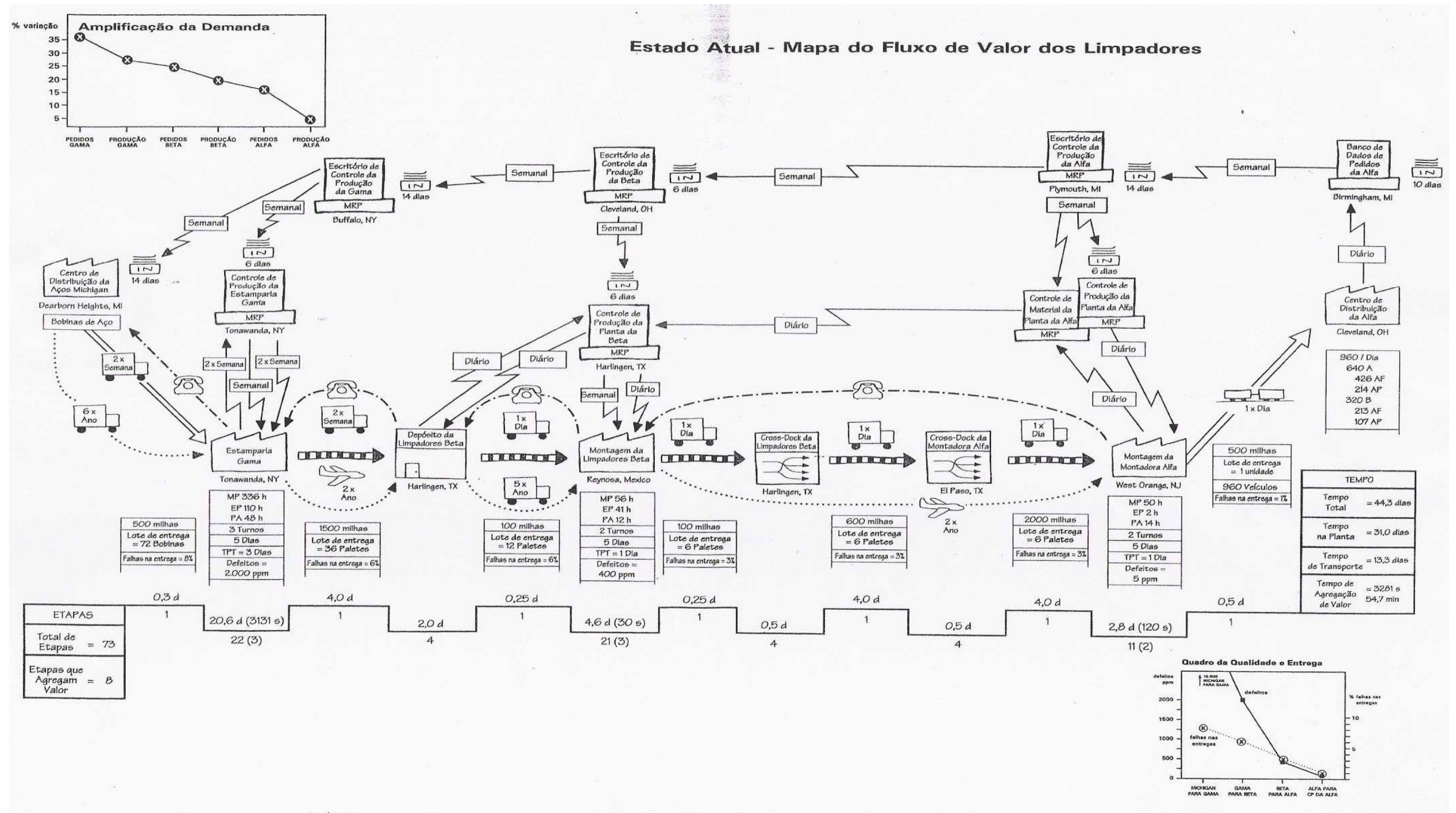

Figura 20 : Mapa do Estado Atual

Fonte: Womack e Jones (2004) 
Este último dado, nível de defeitos, representado pelo gráfico Quadro da Qualidade e Entrega, no canto inferior direito da Figura 20, ilustra como o número de defeitos cai ao longo do fluxo de valor, graças a uma série de departamentos de qualidade em cada planta, onde cada um gera custos de refugo e inspeção. A inclinação da curva representa o gradiente de qualidade, cujo valor deverá decrescer em estados futuros.

Em seguida, os autores abordam as conexões de transportes explicitando o transporte por barco, trem e avião, além do ícone caminhão do Aprendendo a Enxergar. Os números no ícone entrega regular (seta larga com hachuras) mostram a freqüência dos carregamentos, enquanto o número no ícone de expedição (seta pontilhada) mostra o número de entregas de emergência realizadas no ano anterior. Além disso, em cada conexão de transporte registra-se a distância, o tamanho do lote de entrega e a porcentagem de peças defeituosas fornecidas, segundo relato dos clientes. Este dado também se encontra no gráfico do Quadro da Qualidade e Entrega, Figura 20.

Desse modo, pode-se desenhar, na parte inferior do mapa, uma linha de tempo e de etapas (ações ou atividades) e, assim como no mapa de fluxo de valor de uma fábrica, o primeiro número acima de cada segmento da linha é o tempo total dentro de cada planta e ao longo de cada conexão de transporte, enquanto o número entre parênteses, à direita, corresponde ao tempo de agregação de valor.

$\mathrm{Na}$ parte inferior de cada segmento de linha encontra-se o número total de ações realizadas sobre o produto em cada planta e a conexão de transporte. As ações que agregam valor estão mostradas à direita, entre parênteses. Ao fim da linha, encontra-se uma caixa de tempo, mostrando o tempo total, de planta, de transporte e de agregação de valor.

Completa-se o mapa do fluxo físico do produto; resta desenhar o fluxo dos pedidos e das informações da produção a partir do consumidor. Nesse ponto, apresentam os autores outro ícone, o controle da produção. Para se desenhar o fluxo de informações, deve-se começar no ponto em que os pedidos entram no sistema e seguem o fluxo do pedido de departamento a departamento e de sistema de gerenciamento de informações a sistema de gerenciamento de informações, primeiro através da empresa fluxo abaixo, seguindo no sentido dos fornecedores.

Advertem os autores: 
Em quase todas as fábricas, os departamentos de vendas e de controle da produção enviam uma série de previsões, programações e ordens de produção para seus fornecedores. Por exemplo, na indústria automotiva, uma previsão trimestral, uma programação mensal, um programa firme semanal e uma programação diária de entregas podem ser rotineiros. Para os nossos propósitos, a informação importante é a programação semanal fixa a programação diária de entregas, pois são estes os responsáveis por disparar a produção nas plantas e pelas conexões entre elas. (WOMACK e JONES, 2004, p. 29).

Note-se na Figura 20 que estão demonstradas as etapas do gerenciamento da informação e o tempo envolvido, como feito nas ações físicas. Observando a figura, parecem existir dois fluxos de informações chegando a cada planta: a programação semanal dos departamentos de controle de produção de cada empresa e a solicitação diária de cada cliente. Seguidamente, esses fluxos não estão em sintonia, deste modo estabelece-se outra via de gestão, a comunicação direta entre o departamento de materiais de uma planta cliente e o departamento de expedição de uma planta fornecedora. Tal gestão está representada por uma linha pontilhada com o ícone de envio urgente de informação, um telefone.

Sobre isso, alertam os autores:

Essa conexão direta, normalmente uma linha de telefone, torna-se o real controle de produção e o mecanismo de expedição sempre que os gerentes dos dois lados da conexão não levam em consideração as solicitações para expedição e, em situação extremas, as programações de produção. Eles normalmente fazem isso baseados em suas observações diretas de faltas de peças e a definição do que fazer.[...] Sempre nos surpreendemos que empresas lotadas de informações sobre o que deve ser feito tenham tão pouca informação sobre o que realmente aconteceu. Por isso, você terá que investigar bastante ou até mesmo designar um responsável para conseguir informações precisas sobre a produção no chão-de-fábrica e o desempenho de entrega. (WOMACK e JONES, 2004, p. 31).

Essas mudanças ao longo da cadeia de suprimentos causam o efeito de amplificação da demanda. No exemplo da Figura 20, o Banco de Pedidos da Montadora Alfa enviou, semanalmente, pedidos de 960 veículos por dia ao Escritório de Controle de Produção, o qual, por sua vez, semanalmente, enviava um número linear de pedidos para o Controle de Produção das plantas de Alfa e para o Escritório de Controle de Produção de Beta. A produção real difere da programação estabelecida devido à retirada de veículos da seqüência para corrigir defeitos ou por causa de problemas na área de pintura ou, ainda, por falta de peças. Porém, ajustando a programação e trabalhando 
algumas horas-extras ao fim de cada turno, a Montadora Alfa gera na saída uma variação de 5\% com relação às 960 unidades planejadas, sendo todos os veículos montados expedidos diariamente para o Centro de Distribuição Alfa.

Contudo, esta pequena variação de $5 \%$ na produção de Alfa gera uma variação, ilustrada na Figura 21, superior a $10 \%$ na planta de Beta, decorrente do ajuste da programação da produção em Alfa. Ao longo da cadeia, repete-se esse efeito ("Efeito Forrester" em homenagem a quem o estudou, Jay Forrester) até chegar-se à variação de aproximadamente 40\%, Figura 22, dos pedidos feitos pela Estamparia Gama a Aços Michigan. A empresa Beta, Gama e a Aços Michigan precisam proteger-se de eventuais faltas mantendo capacidade extra de produção, amplos estoques de produtos acabados, ou, em ultimo caso, frustrar as expectativas dos clientes. De fato, o mais corriqueiro é manter grandes estoques, assim as implicações para os custos da amplificação da demanda são visíveis na quantidade excessiva de estoques ao longo do fluxo de valor.

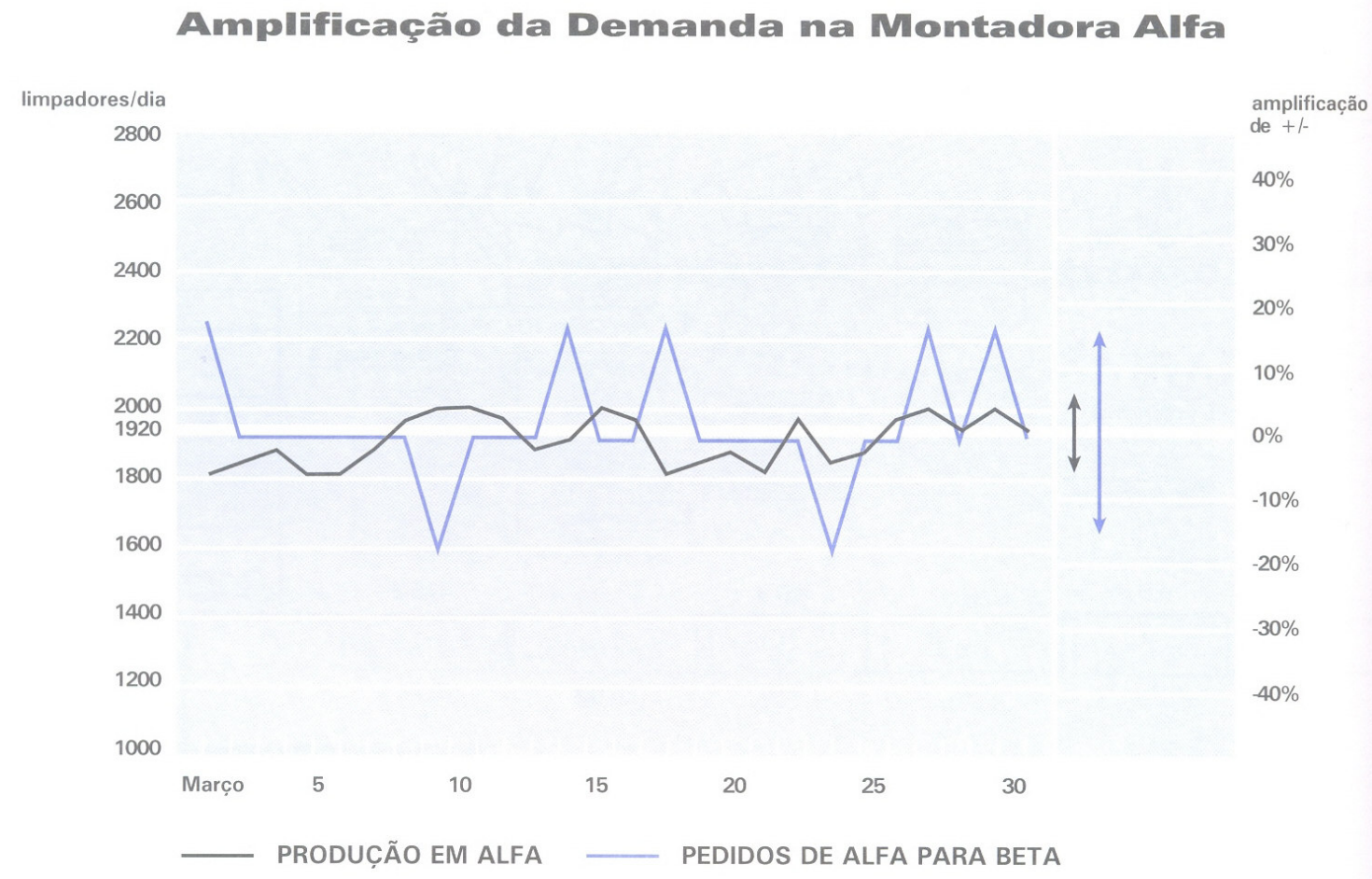

Figura 21 : Amplificação da Demanda na Montadora Alfa Fonte: Womack e Jones (2004) 


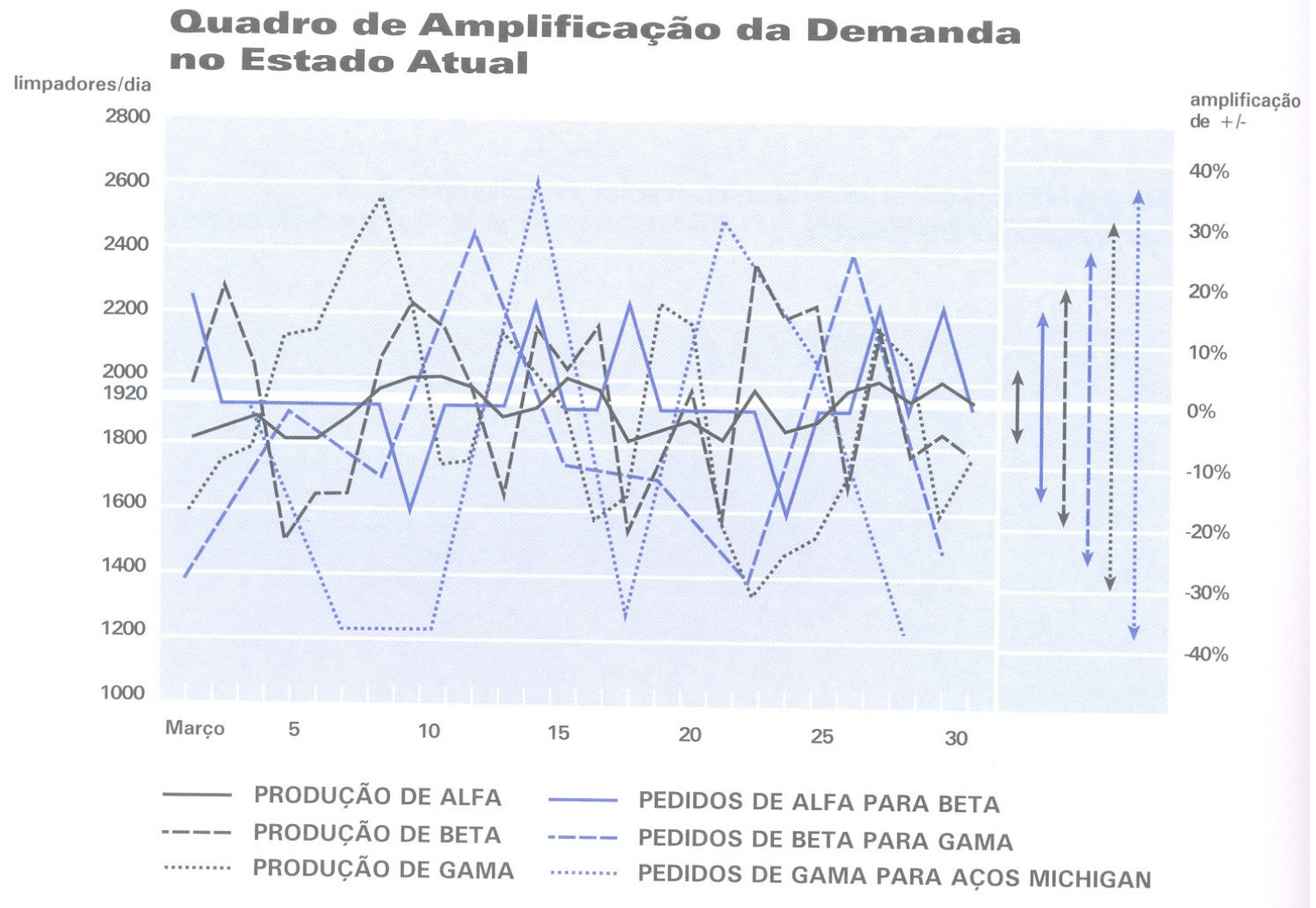

Figura 22 : Quadro de Amplificação da Demanda no Estado Atual Fonte: Womack e Jones (2004)

Afirmam os autores:

As variações no sistema crescem severamente por causa do desalinhamento entre a programação oficial e o que está ocorrendo na realidade. Assim, conforme aumentam esses desalinhamentos, diminui a confiabilidade no sistema formal e cada vez mais se realiza a programação manualmente, apesar dos altos investimentos em tecnologia da informação. (WOMACK e JONES, 2004, p. 31).

Mesmo em cadeias com plantas enxutas, esse efeito se mantém pois ocorrem problemas na produção, problemas no transporte ocorrem em todas as conexões e o feedback sobre as condições atuais e sobre a quantidade de produtos em estoque nunca é suficientemente precisa. Ademais, pequenos lotes de produção e entrega geram um efeito cascata na variação dos pedidos ao longo da cadeia devido aos pontos de programação, oito na Figura 20, e pela demora, 58 dias, antes de se agir sobre a informação. 
Para descrever este fenômeno, Womack e Jones (2004) inserem junto ao mapa de fluxo de valor um gráfico simplificado de Amplificação da Demanda, demonstrado na Figura 20, no canto superior esquerdo do mapa do Estado Atual. Finda a descrição deste mapa do Estado Atual, os autores levantam a questão da causa que torna o fluxo de valor estendido enxuto.

Para respondê-la, citam os sete tipos de desperdícios enumerados primeiramente por Taiichi Ohno: excesso de produção, defeitos, estoque desnecessário, processamento desnecessário, transporte desnecessário entre plantas, espera e movimentação desnecessária no posto de trabalho. Elegem três de especial importância para cadeia de suprimentos: excesso de produção, estoques desnecessários e transporte desnecessário entre plantas, atestando que reduzir essas três formas de desperdício através de melhor gerenciamento dos fluxos de informação e da logística figuram como principal preocupação no mapeamento estendido dos estados futuros.

Tais preocupações conduzem à solução da questão do fluxo de valor estendido enxuto. Primeiramente, todos os participantes da cadeia de suprimentos, por conseqüência do fluxo de valor, devem ser sabedores do ritmo de consumo do produto pelo cliente no ponto final do fluxo, para calcularem seu takt time (freqüência de produção, calculada pela divisão entre a demanda de produtos por unidade de tempo e quantidade de tempo de produção disponível) específico. Receitam os autores:

[...] A produção em cada etapa do fluxo deveria ocorrer em média dentro da mesma taxa, ajustada para a quantidade disponível de tempo de produção em cada etapa e à necessidade de se fazer várias unidades de alguns produtos, a fim de incorporá-las a outros produtos na sequiência do fluxo. [...] É preciso compreender, entretanto, que todas as plantas do fluxo não devem amarrar suas atividades de acordo com a taxa atual da última planta do fluxo. (WOMACK e JONES, 2004, p. 44).

A segunda característica de fluxo de valor estendido enxuto é um baixo nível de estoque de matéria-prima, de estoque em processo e de produtos acabados, adequados para prover as necessidades do próximo cliente do fluxo, dada a variabilidade da demanda das etapas posteriores, a capabilidade dos processos anteriores do fluxo, e o estoque exigido entre as etapas de processo, devido ao tamanho dos lotes e às quantidades nas entregas. Chama-se de estoque padrão as quantias mínimas de estoque necessárias para dar suporte ao cliente, calculados para cada categoria de estoque, de acordo sua função no fluxo. 
Em relação ao uso do estoque, ressaltam os autores:

O ponto principal com relação aos estoques em si é que a equipe elabore um plano estratégico para todas as peças em um estado futuro, descrevendo as razões para a manutenção de certas quantias de materiais e produtos em determinados locais, como estoque padrão. [...] Ao aumentar o estoque num dado ponto, aparentemente um retrocesso, é possível reduzir estoques em outro ponto do fluxo e no fluxo como um todo. (WOMACK e JONES, 2004, p. 46).

Enumeram alguns tipos de estoques, demonstrados na Figura 23:

\begin{tabular}{|c|l|}
\hline Matérias-primas & Produtos entrando em uma planta, ainda não processados. \\
\hline Estoque em processo & Itens entre as etapas de processamento, dentro de uma planta. \\
\hline Produtos acabados & Itens prontos esperando expedição. \\
\hline Estoques de segurança & $\begin{array}{l}\text { Itens mantidos em qualquer ponto (matérias-primas, estoque em } \\
\text { processo ou produtos acabados) a fim de prevenir o não- } \\
\text { atendimento das necessidades dos clientes, devido a problemas na } \\
\text { capabilidade do processo nas etapas anteriores do fluxo. }\end{array}$ \\
\hline Estoques pulmão & $\begin{array}{l}\text { Itens estocados, normalmente na etapa final do fluxo de uma planta } \\
\text { ou de um processo, a fim de proteger os clientes, caso haja um } \\
\text { súbito aumento de demanda por um determinado cliente (uma } \\
\text { demanda que exceda a capacidade de produção). }\end{array}$ \\
\hline Estoques para entrega & $\begin{array}{l}\text { Itens esperando embarque na etapa final do fluxo de uma planta, } \\
\text { armazenados para a expedição seguinte. São geralmente } \\
\text { proporcionais aos tamanhos dos lotes e freqüências das remessas. }\end{array}$ \\
\hline
\end{tabular}

Figura 23 : Tipos de estoques

Fonte : Womack e Jontes (2004)

Uma terceira marca de um fluxo de valor estendido enxuto é o menor número possível de conexões de transporte entre as etapas do processo de produção. Uma quarta distinção de um fluxo de valor estendido enxuto é o menor processamento possível de informações, com puro sinal e nenhum ruído nos fluxos de informação remanescentes. Uma quinta característica do fluxo de valor enxuto é o menor lead time (tempo que decorre entre o instante de entrada de um item no sistema até o instante de saída deste item do sistema) possível, ou seja, reduzir ao máximo o tempo entre a entrada de matéria-prima e a entrega ao cliente.

Por fim, o último princípio de um fluxo de valor estendido é que as mudanças introduzidas para melhorar o fluxo, eliminar estoques, diminuir as conexões de transporte e encurtar o lead time, devem envolver o menor custo possível ou mesmo nenhum custo. Atestam os autores: 
O último princípio sugere que cuidemos dos fluxos de produto na planta usando primeiramente os métodos descritos em Aprendendo a Enxergar e Criando Fluxo Contínuo, os quais não implicam gastos vultuosos, e que criarão o nosso chamado Estado Fututo 1. (WOMACK e JONES, 2004, p.49)

Depois de implementado o Estado Futuro 1, através da disseminação do pensamento enxuto na cadeia, é possível suavizar o fluxo de valor e reduzir a necessidade de pulmões, implementando feedbacks diretos com mecanismos de nivelamento para as informações fluindo de cada cliente do fluxo ao seu fornecedor direto. Reduz-se, desse modo, o tamanho dos lotes de entrega, com simultâneo aumento de frequiência das entregas entre cada planta e seu cliente direto. Tais ações caracterizam os objetivos do Estado Fututo 2. Desse modo, pode-se empreender ações no sentido do Estado ideal, baseado nos princípios de que:

- todas as etapas da produção devem ser realizadas o mais perto possível uma das outras;

- quanto mais próxima do cliente for essa seqüência, melhor, e

- se a proximidade acarreta custos adicionais de produção, tais custos devem ser comparados com o valor da economia de tempo que pode ser obtida.

Para ilustrar as ações acima descritas consultem-se as Figuras 24 e 25. Note-se que devido ao sistema de Kanban aliado a lotes menores e mais freqüentes de entrega (milk run), eliminaram-se o Depósito de Limpadores Beta, o Cross-Dock da Limpadores Beta e o Cross-Dock da Montadora Alfa. No mapa do Estado Ideal, vemos um condomínio industrial, sendo a movimentação dos materiais entre Alfa, Beta e Gama realizada por um "homem aranha", trabalhador responsável pelo transporte dos produtos acabados de uma célula, no caso planta, para próxima cliente. 


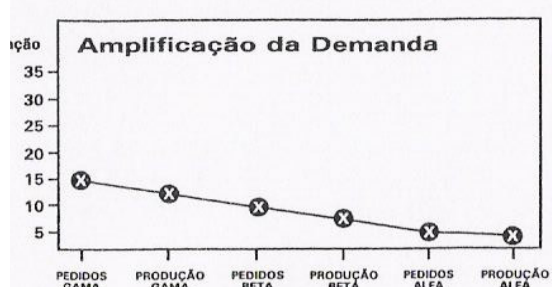

Estado Futuro 2 - Mapa do Fluxo de Valor dos Limpadores

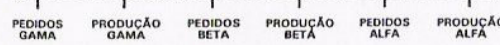
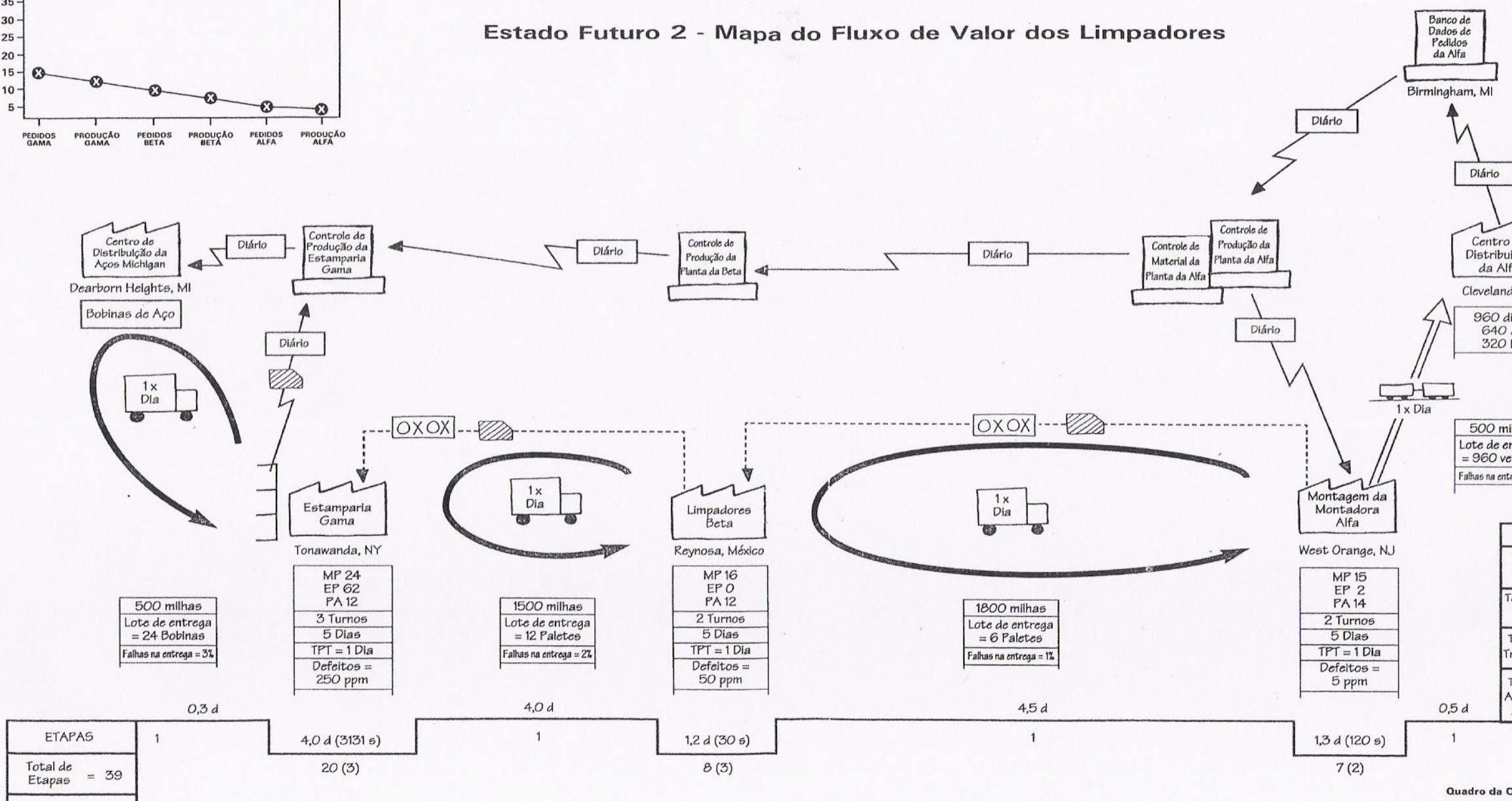

Figura 24 : Mapa do Estado Futuro 2

Fonte: Womack e Jones (2004) 


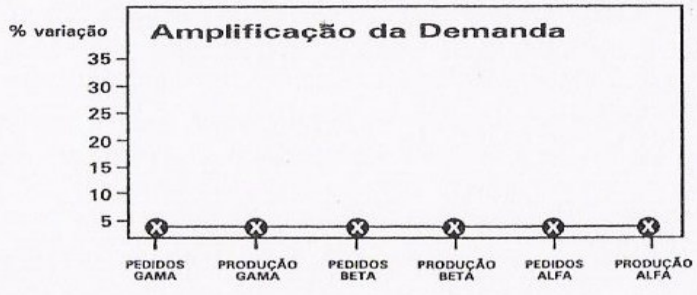

Estado Ideal - Mapa do Fluxo de Valor dos Limpadores

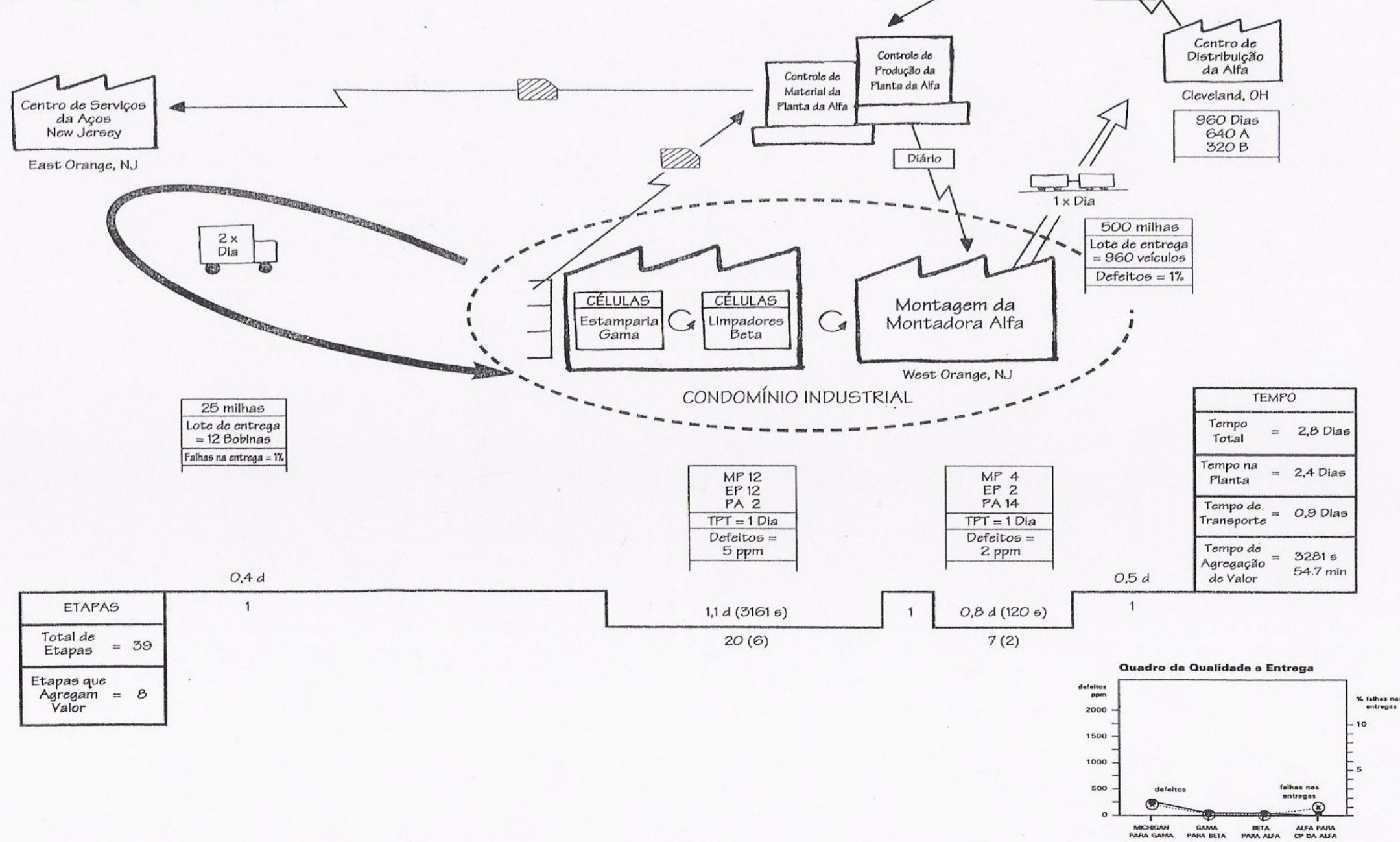

Figura 25 : Mapa do Estado Ideal

Fonte: Womack e Jones (2004) 
Sobre custos argumentam Womack e Jones (2004, p.73):

Se for possível comparar o custo do produto total antes e depois das melhorias no estado futuro, a compensação (entre as empresas do fluxo) pode ser uma questão mais fácil. Contudo, os sistemas de compra e de contabilidade tradicionais, geralmente não são compatíveis entre os participantes do fluxo, além de não serem adequados ao cálculo dos custos do produto para cada família. Esses sistemas normalmente requerem quantidades enormes de dados para alocar as despesas gerais e eles costumam falhar para calcular os custos de um modo que todos os participantes aceitem como válido. Propomos o uso de um sistema simples, ignorando os sistemas tradicionais, determinando o custo marginal (em uma moeda comum a todos) e o benefício marginal (na mesma moeda) de cada mudança proposta no fluxo de valor nos estados futuro e ideal.

Este breve comentário pode anuviar a potencialidade do mapeamento do fluxo de valor estendido em relação aos custos. Lembre-se que a primeira ação a se realizar é listar e registrar a duração de cada atividade (ação) ao longo da cadeia de suprimentos. Concomitante passo ocorre no custeio baseado em atividades.

\subsection{Considerações}

Ao termo deste capítulo, pode-se divisar a característica integrada e integradora da logística, advinda principalmente das mudanças organizacionais. A contenda entre foco funcional e foco por processo ditou novas atribuições, responsabilidades e práticas para logística. Apesar disso, é interessante notar como a visão de cunho abrangente de um general do início do século XIX volta à baila. Abrangente, pois os processos logísticos não mais estão encarcerados na empresa, mas ao longo de uma cadeia de empresas que cooperam para levar seus produtos / serviços ao mais baixo custo para os clientes.

Como visto anteriormente, esta cadeia pode ser modelada por ícones simples e retratada com informações vitais à sua competitividade. Tempo, estoque e valor são palavras recorrentes quando se trata da redução de custos dos processos. Para isso tais processos precisam ser identificados, nomeados e medidos. Isso é feito através da caracterização das atividades. A implementação do custeio baseado em atividades passa por esta mesma fase. 


\section{CAPÍTULO 4 - SOBRE A IMPLANTAÇÃO DO ABC}

Este capítulo trata da implantação do custeio baseado em atividades. Para tal, como dito anteriormente, elegeu-se o método adotado pela Consultoria Ernest \& Young para implantação em geral (ou seja, em qualquer função da empresa). Segue descrevendo tal método, bem como outros, no intuito de dar luz ao problema central do trabalho.

\subsection{O método adotado}

O método de implantação do custeio baseado em atividades que se utilizará é descrito no Guia da Ernst \& Young para Gestão de Total dos Custos de Ostrenga et al. (1993). Este é composto por três partes: a primeira compõe-se de um sumário geral que aborda termos gerais da gestão total dos custos; a segunda examina três técnicas sugeridas como fundamentais, a saber, a análise de processos de negócios, o custeio baseado em atividades e melhoria contínua, e a terceira, que explora como implementar a gestão total de custos em uma empresa. Bem claro deixam os autores, que o guia não é panacéia, mas conjunto de técnicas para identificação e controle de custos.

Esse método, eleito entre plêiade de outros, deve-se ao fato do custeio baseado em atividades compor, com outras técnicas, uma forma de gestão total dos custos, por que, teoricamente, pode ser utilizado em qualquer função de uma empresa, por possuir um exemplo claro do custeio baseado em atividades aplicado a logística de distribuição e por apresentar a formação de um relatório do sistema proposto.

Para se demonstrar como funciona o método serão abordadas as partes do guia, resumidamente, relacionadas ao custeio baseado em atividades. Inicia-se com o 
sumário geral, que basicamente delineia o contexto empresarial e as mudanças requeridas dos sistemas contábeis, elegendo o método sugerido, doravante nomeado gestão total de custos de acordo com o texto, como alternativa de factível solução. Para isso, evidencia como a gestão total de custos provê conceitos e informações de custos, que segundo Ostrenga et al. (1993) “[...] ajudam a analisar os processos do negócio, a melhorar a base analítica para planejamento e melhorar o desempenho em toda a empresa".

$\mathrm{Na}$ contextualização, os autores ressaltam como a proliferação de produtos e serviços devido às pressões pela eficiência, qualidade e competição global causam aumento generalizado de custos, e como a automação faz o mesmo aos custos indiretos em relação aos diretos.

Essas velhas técnicas [contábeis] foram desenvolvidas em uma época na qual o ambiente de negócios diferia dramaticamente daquele hoje enfrentado pelas empresas. Algumas dessas antigas técnicas davam destaque aos seguintes pontos:

- A minimização dos custos de mão-de-obra direta era considerada a chave para alta produtividade.

- Os custos indiretos eram baixos comparativamente aos diretos.

- As empresas tinham uma visão predominantemente doméstica de seus mercados, fornecedores e concorrentes.

- A estratégia dominante era a produção em massa e não a variedade de produtos/serviços.

- A alta qualidade dos produtos ou serviços era vista como um meio para se cobrar preços mais altos e não como uma condição para a permanência no mercado.

- Os serviços desempenhavam um papel muito menor na definição da estratégia. (OSTRENGA et al., 1993, p. 18-19).

Em decorrência desses fatores, apontam quatro deficiências dos relatórios gerenciais de custos:

1. foco contábil ao invés de foco gerencial;

2. decisões de planejamento sobre produtos/serviços baseados em informações, na melhor das hipóteses, errôneas;

3. o questionável papel do processo de justificação do capital, baseado na taxa de retorno interna, totalmente desassociada de efeitos de investimentos na qualidade, flexibilidade e capacidade de reação da empresa;

4. quadro incompleto do desempenho. 
Finalmente, justificam porque a gestão total de custos é a melhor solução para o custeio

[...] o TCM [Total Cost Management] é mais abrangente, flexível e pró-ativo que os outros [sistemas de custos]. O que torna o TCM tão adaptável e eficiente? Em parte, a resposta está na natureza dos seus três princípios básicos, que são análise do processo do negócio, custeio baseado em atividade e aperfeiçoamento contínuo. (OSTRENGA, et al., 1993, p. 34).

Que sejam abordados tais princípios.

\subsubsection{Análise de processos do negócio (BPA - Business Process Analysis)}

A análise de processos do negócio consiste em "ver" a organização por processos, estes em subprocessos e, por fim, estes em atividades que se tornam foco de toda análise. Deste modo, pode-se "ver" a empresa através dos olhos do cliente. Ostrenga et al. (1993, p. 78) enfatizam:

A razão pela qual o TCM enfatiza a visão de processo permite que a organização projete o trabalho em torno de uma meta gerencial ou de um requisito do cliente, sem necessariamente mudar a estrutura da organização. Portanto, a visão de processo dá à empresa uma compreensão mais clara da sua eficácia na satisfação das necessidades do cliente e também na realização do seu trabalho.

Além disso, de acordo com o método proposto de gestão total de custos, a análise de processos do negócio pode ser utilizada como um fim em si mesma, à medida que a empresa se empenhe em melhorar o desempenho organizacional e, também, por ser uma etapa preliminar que complementa as outras técnicas da gestão total de custos.

Depois de discriminadas as atividades decorrentes da análise de processos de negócio, realiza-se a análise de valor de processo, classificando-se as atividades em aquelas que agregam valor (cuja execução os clientes consideram importante) e aquelas que não agregam valor (que os clientes consideram sem importância ou pela qual não estão dispostos a pagar). Os autores destacam: "Atividades que não agregam valor são aquelas que não afetam a qualidade, o desempenho ou a funcionalidade do produto". (OSTRENGA et al., 1993, p.81).

Em seguida, realiza-se o custeio dos objetos (produtos, linhas de produtos, serviços, clientes, segmentos de clientes, canais de distribuição ou qualquer outra coisa 
do interesse da gerência). Apoiando-se na análise de valor, pode-se compreender porque um objeto custa o que custa e a ação corretiva que deve ser executada. Após a identificação de possibilidades de melhoria e redução de custos, deve-se criar indicadores de desempenho por processo e eleger um "proprietário executivo", com responsabilidade global pelo desempenho de seu processo, com o objetivo de criar um método de avaliar decisões que evidenciem as dinâmicas de tempo, qualidade e custo em termos de benefícios financeiros.

Ostrenga et al. (1993) fornecem quatro passos para realizar uma análise de processo de negócio:

1. desenvolver um modelo do processo;

2. desenvolver uma definição de processo-atividade;

2.1. identificar o resultado (produtos e serviços) do processo,

2.2. identificar os clientes (internos e externos) para os produtos e serviços,

2.3. identificar o trabalho executado na criação do resultado,

2.4. identificar o insumo do processo;

3. efetuar uma análise de valor do processo, e

4. desenvolver um plano de aperfeiçoamento.

Para desenvolver um modelo do processo do negócio, os autores citam a visualização da empresa pela cadeia de valores de Porter (1992). Esse autor propõe uma forma sistemática para analisar as fontes da vantagem competitiva, a cadeia de valores. Esta separa uma empresa em suas atividades de relevância estratégica para compreensão dos custos e as fontes potenciais de diferenciação. Uma empresa conquistaria vantagem competitiva executando tais atividades estrategicamente importantes de uma forma mais barata, ou melhor que os concorrentes.

A cadeia de valores de uma empresa se encaixa num sistema de valores. A obtenção e a sustentação de uma vantagem competitiva dependem da compreensão de como a empresa se enquadra no sistema de valores geral, uma vez que este pode variar em escopo, representando uma fonte em potencial de vantagem competitiva. A Figura 26 representa um sistema de valores geral de uma empresa que participa de uma única indústria e de outra empresa diversificada em escopo. 
Empresa de uma única Indústria
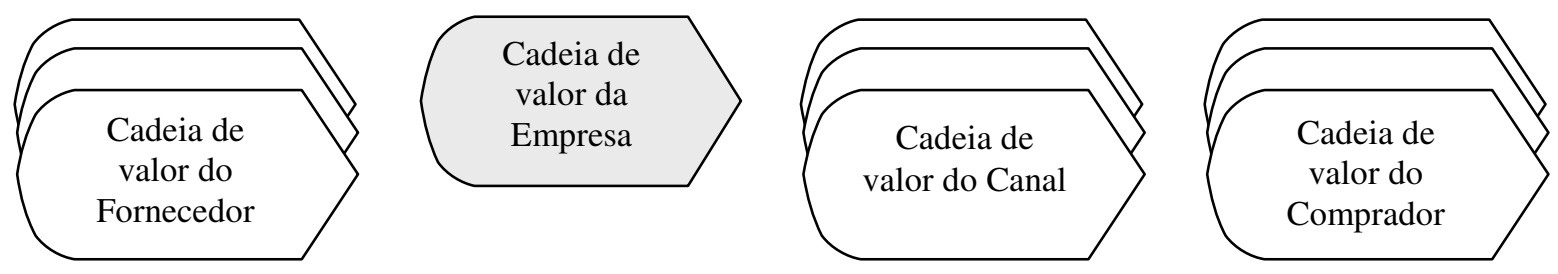

Empresa diversificada

Cadeia de valor da Empresa

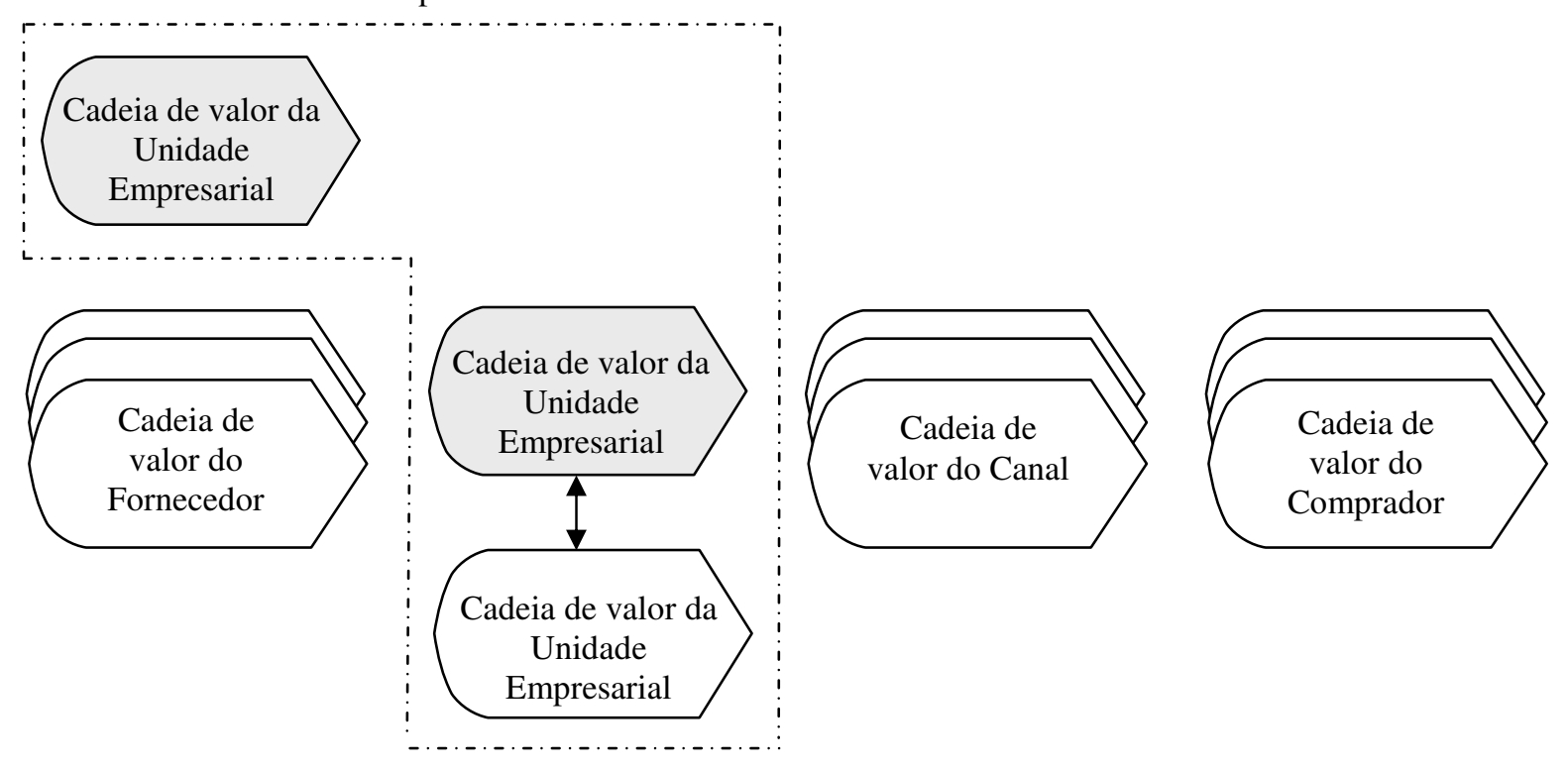

Figura 26: O Sistema de valores

Fonte: Porter (1992)

Para Porter (1992) uma empresa pode ser representada por suas atividades fazendo uso de uma cadeia de valores, cujos níveis são atividades de uma empresa em uma indústria específica. As diferenças nas cadeias de valores entre concorrentes de uma mesma indústria - por exemplo, variações na linha de produtos, compradores, áreas geográficas ou canais de distribuição diferentes - são fontes básicas de vantagem competitiva. A Figura 27, demonstra a idéia de cadeia de valores de uma empresa. 


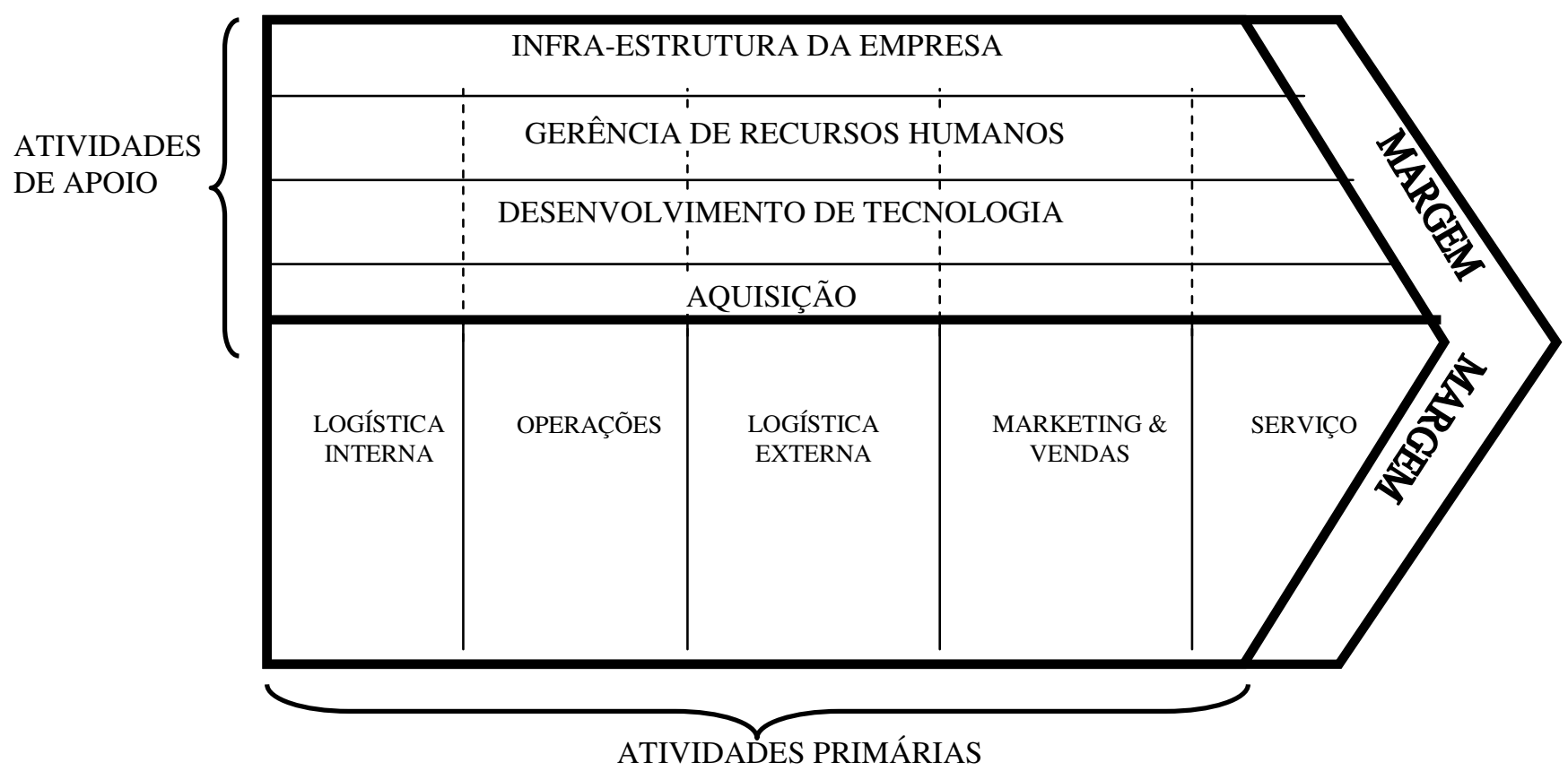

Figura 27 : A Cadeia de valores genérica Fonte: Porter (1992)

Na Figura 27, a margem representa a diferença entre o valor total (montante que os compradores estão dispostos a pagar por aquilo que uma empresa oferece) e o custo coletivo da execução das atividades de valor. Estas podem ser divididas em dois tipos principais, as primárias e as de apoio. As primárias abrangem a criação física do produto, sua venda, transferência para o comprador e assistência pós-venda. As de apoio sustentam as primárias e a si mesmas, envolvem fornecimento de insumos adquiridos, tecnologia, recursos humanos e várias funções na empresa.

Apesar de citar a cadeia de valores de Porter (1992), Ostrenga et al. (1993) fornecem um meio pragmático para gerar o modelo de processo do negócio:

O objetivo do modelo de processo do negócio é identificar os principais fluxos de processo dentro de uma organização. O modelo do processo é essencialmente um fluxograma de processos específicos de alto nível interligados para mostrar fluxos de processo, os quais podem ainda ser divididos em subprocessos e suas atividades de apoio. O modelo do processo provê uma visão global da organização, mostrando, assim, os principais processos da empresa e as relações entre eles. [...] Ao definir seus subprocessos, [sic] é importante identificar os limites do processo. Por exemplo, se o subprocesso for processamento de pedidos, é preciso estabelecer os pontos inicial e final do processo. $O$ ponto inicial pode ser "Recebimento de um pedido de um cliente" e o final "Recebimento 
dos bens pelo cliente". A especificação dos limites clarifica o conteúdo de cada subprocesso.

E ilustram, como mostrado nas Figuras 28 e 29.

Quanto à definição das atividades, o segundo passo, Ostrenga et al..(1993) ressaltam:

A intenção da definição das atividades não é a realização de um estudo de micromovimentos, como fazem alguns engenheiros industriais para obter dados de custo padrão. Em vez disso, ela pretende desenvolver a compreensão dos principais trabalhos realizados no curso natural dos negócios. Portanto, a definição da atividade não desce ao nível de tarefa.

E fornecem quatro sugestões para identificar atividades:

1. depois de listadas as atividades, verificar se a identificação está completa, mormente "caminhos secundários" no fluxo de trabalho existem.

2. usar sessões em grupo facilitadas ao invés de entrevistas individuais.

3. verificar a multiplicidade de caminhos no fluxo de trabalho.

4. escolher uma ou as duas principais abordagens à identificação de atividades.

As abordagens na sugestão quatro referem-se ao sentido de identificação das atividades: "de cima para baixo", ou seja, identificar as abordagens como uma continuação da divisão de processos em subprocessos, e "de baixo para cima", em que a intenção é a de estabelecer as atividades, os subprocessos e os processos.

É interessante notar que os autores afirmam que se pode utilizar o custeio baseado em atividades como técnica contígua ou não do processo de análise do negócio.

Se você já executou uma análise do processo do negócio, então as atividades (conforme definidas no BPA) devem ser o ponto de partida para a especificação das atividades nas quais irá se basear seu custeio. Entretanto, normalmente a definição de atividade requerida para uma eficaz análise dos processos do negócio é mais detalhada que aquela requerida para o cálculo de produtos ou outros objetos de custo. (OSTRENGA et al.., 1993, p.173). 


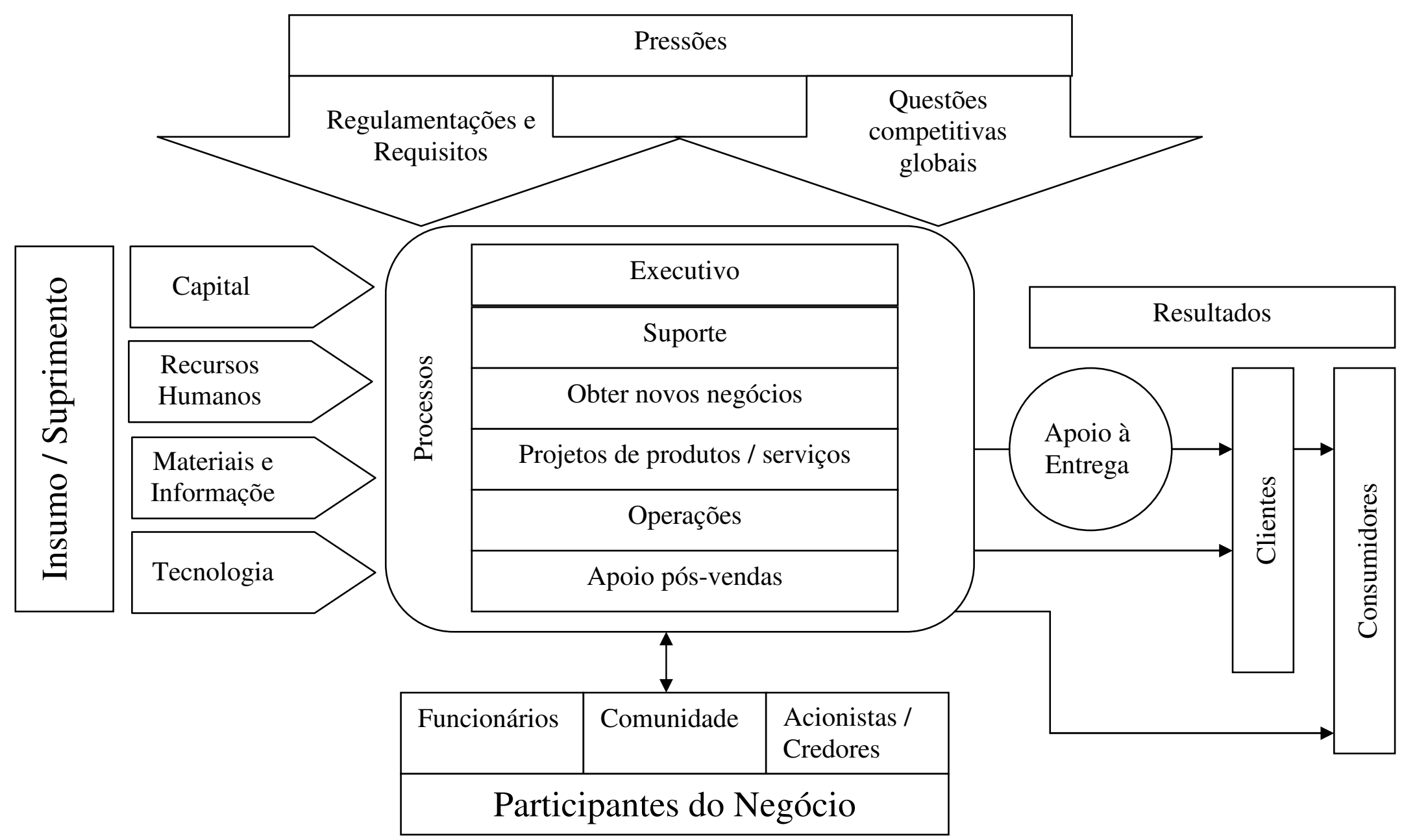

Figura 28 : Modelo de negócio baseado em processos

Fonte : Ostrenga et al. (1993) 


\begin{tabular}{|c|c|c|c|c|c|}
\hline $\begin{array}{l}\text { Processos } \\
\text { Executivos }\end{array}$ & Suporte & $\begin{array}{c}\text { Obter novos } \\
\text { negócios }\end{array}$ & $\begin{array}{l}\text { Projeto de } \\
\text { produtos / } \\
\text { servicos }\end{array}$ & Operações & $\begin{array}{l}\text { Apoio Pós- } \\
\text { Vendas }\end{array}$ \\
\hline
\end{tabular}

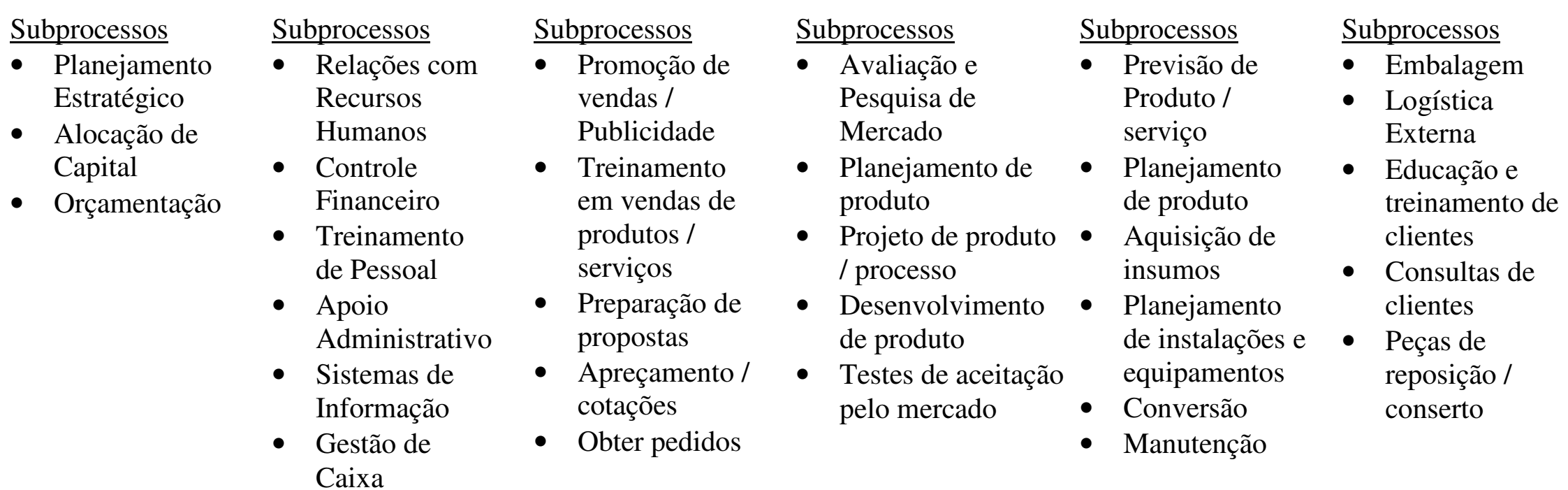

Figura 29 : Modelo típico de processo de negócio (com subprocessos)

Fonte: Ostrenga et al. (1993) 
Não obstante, para reforço do presente trabalho, ressaltam:

Apesar de a metodologia da Ernst \& Young recomendar fortemente que você realize a análise do processo do negócio antes de iniciar um projeto de custeio baseado em atividades você pode encontrar situações nas quais essa sequiência não é possível. (OSTRENGA et al., 1993, p.175).

Uma destas situações ocorre quando o escopo da análise de processos do negócio não contemplou um processo que, necessariamente, será utilizado no cálculo do custo de um objeto. Com isso, os autores fornecem a possibilidade teórica e prática para que o custeio baseado em atividades, umas das técnicas da gestão total de custos, possa ser utilizado separadamente da análise de processos do negócio sem incúrias.

E mais, para tal situação acima descrita, os autores recomendam:

A maneira mais eficaz para colher essas informações é através de entrevistas com os gerentes das áreas funcionais. A finalidade dessas entrevistas é colher informações suficientes para identificar os serviços fundamentais, os clientes desses serviços e as bases adequadas de alocação. (OSTRENGA et al., 1993, p.176).

Na seqüência, o terceiro passo para realizar a análise de processos do negócio consiste na análise de valor do processo. Tal técnica evidencia atividades que demandam tempo e/ou custo a um processo, sem agregar valor aos olhos do cliente e facilita a análise das atividades que não agregam valor, para eliminar suas causas básicas. Dados necessários à análise incluem tempo de ciclo, custo e estimativa de valor dos clientes das atividades.

A saída da técnica de análise de valor é um modelo de atividades com tempo, custo e estimativa de valor, como mostrado na Figura 30: 


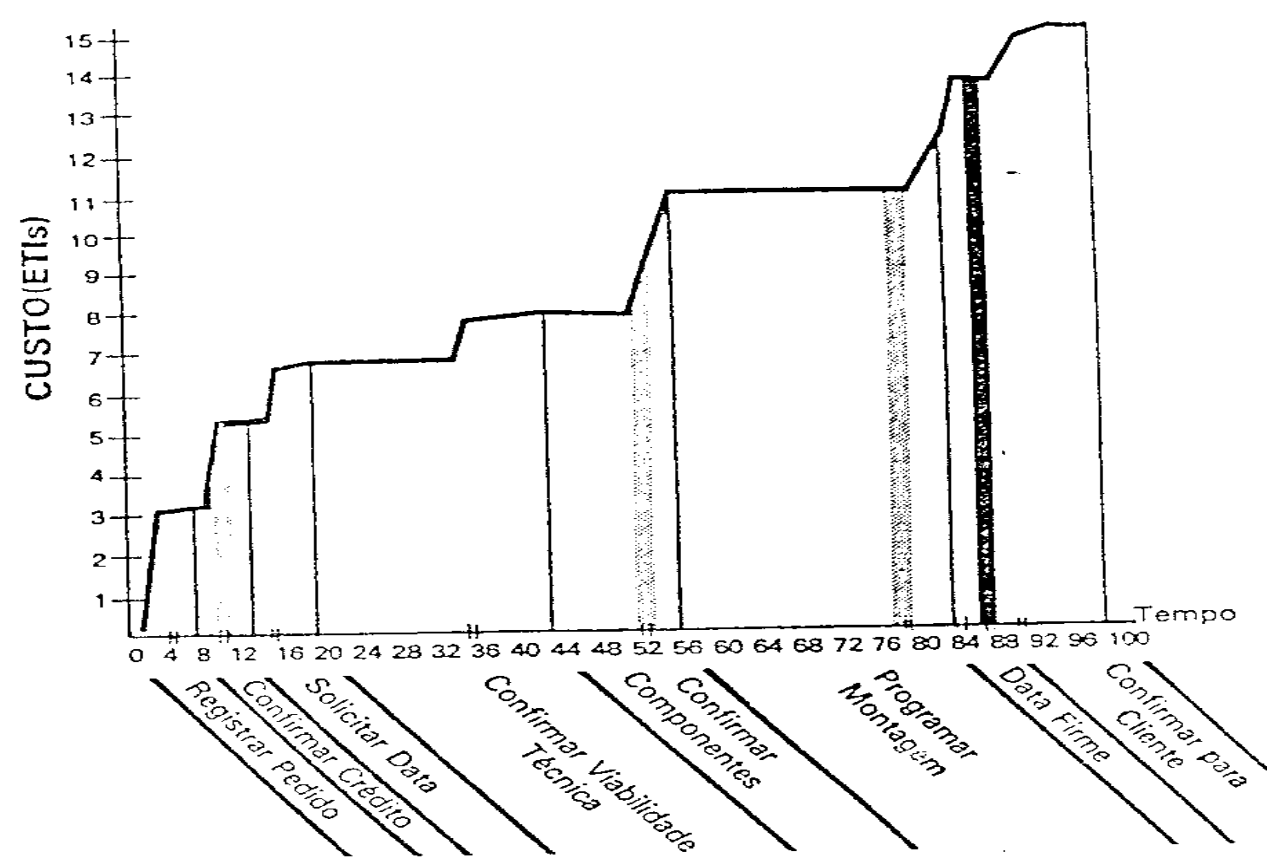

Figura 30 : Modelo de atividades com tempo e custo Fonte : Ostrenga et al. (1993)

O tempo de ciclo do processo é o tempo necessário à conclusão de todo o processo. Registra-se o tempo de ciclo para cada atividade e, em seguida, estimam-se os recursos necessários para as atividades, ressaltando-se a importância de especificar a unidade a ser usada para medir os recursos para, então, estimar o valor agregado de cada atividade, através do valor percebido pelo cliente. Este pode ser determinado por questionários, entrevistas e etc. Finalmente, dividem-se em atividades naquelas que não agregam valor (NVA) e nas que agregam valor (VA) para concentrar esforços em encontrar maneiras de eliminar o trabalho que não agrega valor ao processo e encontrar maneiras para aumentar a eficiência e eficácia do trabalho que agrega valor.

Sem olvidar a seqüência sugerida por Ostrenga et al. (1993) para realizar a análise de processo de negócio, esclarece-se o último passo: desenvolver um plano de aperfeiçoamento. Esta etapa, anunciam, possui duas sub-etapas: a primeira, identificar os problemas e suas causas básicas, a segunda, resolvê-los através da recomendação de soluções e da elaboração de um plano de implementação.

Recorde-se que, como saídas da análise de processo de negócio, até este ponto da análise tem-se:

- um fluxograma dos processos da empresa, incluindo insumos, resultados, limites e clientes e as relações entre os processos e suas atividades; 
- informações, resultantes da análise de valor do processo, de cada atividade como: tempo de ciclo, necessidades de recursos e estimativa de valor agregado.

De posse destas informações Ostrenga et al. (1993) recomendam o desenvolvimento de um plano de aperfeiçoamento do processo, através da identificação dos problemas do processo e determinação das causas básicas. Para identificar os problemas, deve-se realizar sessões em equipes compostas por gerentes e trabalhadores que estão dentro do processo. Os autores destacam problemas recorrentes: lacunas (serviço anunciado versus serviço entregue), desperdício (presença de atividades que não agregam valor), ineficiência (sequiência do fluxo de trabalho) e instabilidade (variações nos insumos, resultados, tempos e/ou qualidade).

Para identificar as causas básicas de um problema, Ostrenga et al. (1993) sugerem uso de um processo estruturado de brainstorming pelas pessoas envolvidas no processo que abriga o problema em questão. Tal técnica consiste em esboçar um "diagrama espinha de peixe", com quatro categorias de elementos de processos: insumos, pessoas, métodos e tecnologia. Como mostra a Figura 31, abaixo:

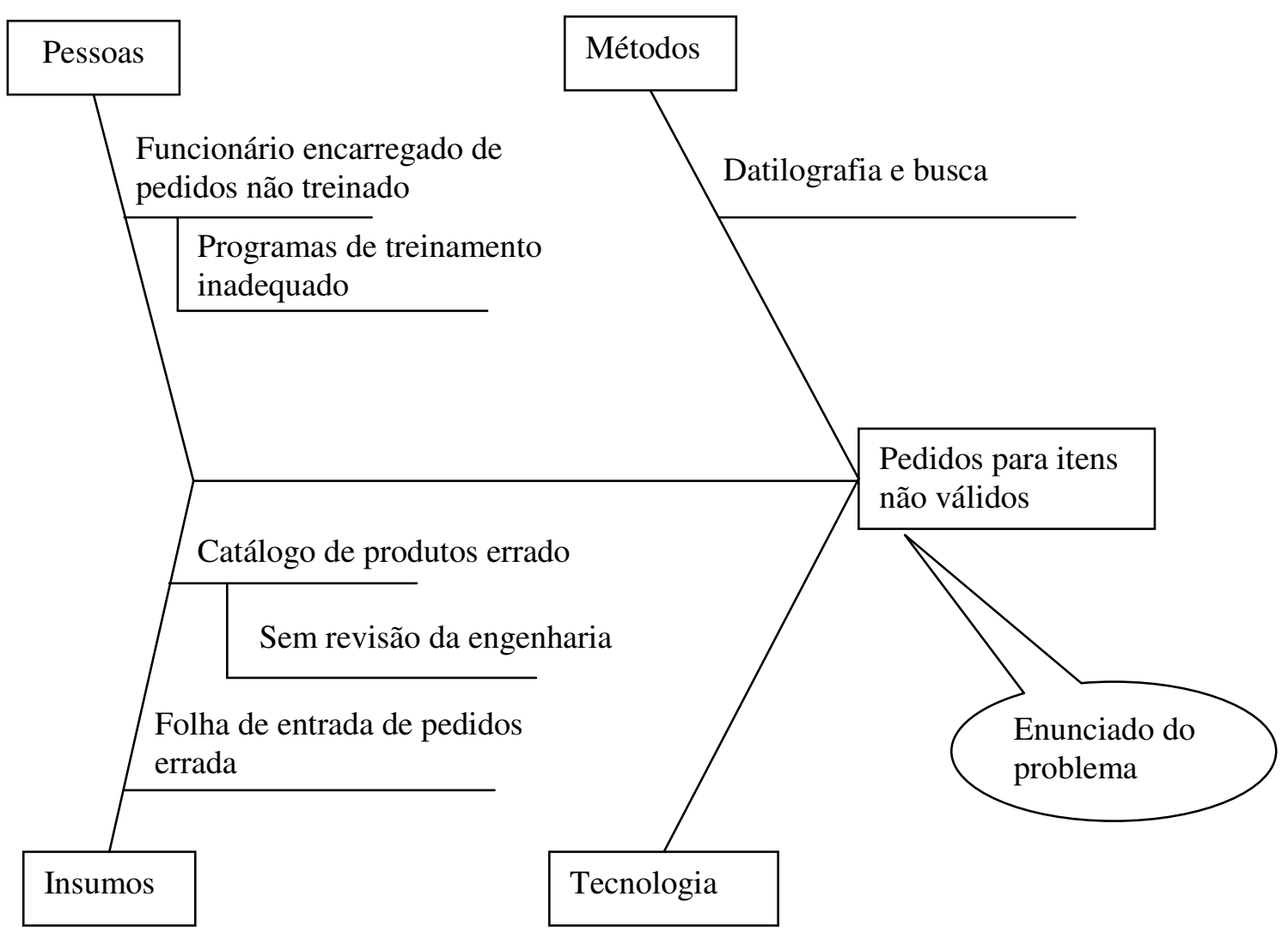

Figura 31 : Diagrama espinha de peixe: análise detalhada Fonte : Ostrenga et al. (1993) 
Devido ao foco estabelecido neste estudo, abordar métodos para solução de problemas, apesar de interessante, causa alargamento desnecessário. Opta-se por omitir tais métodos, para chegar-se à técnica do Guia da Ernst \& Young para Gestão de Total dos Custos que mais interessa ao trabalho: o custeio baseado em atividades.

\subsubsection{Custeio baseado em atividades (ABC)}

Importante é evidenciar o enfoque distinto do método de custeio baseado em atividades proposto no referido guia, pois além de apresentar, descrever e ilustrar, aborda questões fundamentais que devem ser atacadas durante a implementação e expõe como usar os resultados do custeio baseado em atividades na tomada de decisões gerenciais.

Inicialmente, Ostrenga et al. (1993) abordam como se desenvolveu o custeio baseado em atividades, esclarecendo como a proliferação de atividades de apoio que não agregam valor causam o aumento dos custos indiretos. E como a diversidade e complexidade de produtos e processos podem ser avaliadas em termos de custos pelo custeio baseado em atividades.

Outrossim, anunciam três elementos centrais da abordagem da Ernst \& Young ao custeio baseado em atividades:

Em primeiro lugar, os importantes benefícios do $\mathrm{ABC}$ dependem da equipe do projeto em compreender de fato a dinâmica daquilo que causa os custos indiretos na empresa. A análise do processo do negócio é a principal técnica para a obtenção desses conhecimentos. [...] O segundo ponto [...] Um projeto de $\mathrm{ABC}$ não pode ser conduzido com sucesso como um projeto contábil de 'sala dos fundos'. Um projeto de $\mathrm{ABC}$ é um dos melhores veículos possíveis para fazer com que o pessoal de operações conheça as disciplinas e desafios do pessoal da contabilidade e vice-versa. Nenhum grupo trabalhando sozinho possui todos os conhecimentos e qualificações necessários à realização de alguma coisa significativa no projeto. [...] $\mathrm{O}$ terceiro a notar é que uma abordagem de $\mathrm{ABC}$ é muito mais uma questão de mentalidade do que de software. Uma abordagem que privilegia a compreensão da dinâmica dos custos será muito mais valiosa para você do que o próprio 'sistema'. (OSTRENGA et al., 1993, p.167)

Tais elementos servem ao objetivo central da técnica na gestão total dos custos, que é alocar custos que reflitam ou espelhem a dinâmica física da empresa, no intuito de estabelecer uma ligação entre o aumento da exatidão do custeio e a melhoria do desempenho da empresa. 
Passando-se para implementação do custeio baseado em atividades, Ostrenga et al. (1993) fornecem um roteiro com detalhados preparativos de planejamento. Neste ponto do guia, fica evidente a atenção que é dada para a implementação do método. Os autores recomendam uma definição clara das metas, do escopo e dos objetivos do projeto de custeio baseado em atividades. Com isso, delimitam o alvo a ser atingido durante os esforços para utilização da técnica.

Para implementação, destinaram um capítulo do guia (Capítulo 11, Custeio Baseado em Atividades - Um Jogo de Ferramentas), resumidamente descrito a seguir.

Inicialmente, deve-se realizar uma revisão dos atuais sistemas de custos, com o objetivo de conhecer os dados existentes no sistema, saber como essa base de dados é usada no método atual de custos e começar a documentar os dados que podem ter valor no esforço do $\mathrm{ABC}$.

Em seguida, identificar o fluxo de custos atual e desenvolver um esquema de como os custos fluem do livro contábil para os objetos de interesse, no intuito de compreender a arquitetura de custos atual e estabelecer um ponto de controle para garantir que nenhum elemento de custo seja olvidado. Para tanto, Ostrenga et al. (1993) ressaltam algumas perguntas.

- Como materiais e mão de obra são cobrados?

- Como são cobrados os custos indiretos?

- Quantos são os centros de custos indiretos?

- Quantos são os níveis de alocação?

- Os custos indiretos são alocados diretamente dos centros de custos aos objetos ou ocorrem alocações intermediárias?

- Se existe um sistema de custo padrão, até que ponto os custos que não agregam valor estão ocultos nos padrões?

- Os fatores de refugos, retração, repetição de trabalhos e eficiência foram embutidos nos padrões?

- Já existem análises de lucratividade para os objetos? Caso existam, incluem custos não inventariáveis? Por exemplo, eles incluem custos de marketing, distribuição ou vendas? Se afirmativo, como são determinados esses custos?

O passo seguinte na revisão do atual sistema de informação de gestão de custos é familiarizar-se com o desenvolvimento das técnicas de custos indiretos 
documentando o tipo dos grupos de custos indiretos, o nível em que são mantidos os grupos e a base de alocação usada para cada grupo, no intuito de identificar dinâmicas específicas que possam causar distorções nos custos correntes.

Depois de consciente do atual sistema de gestão de informações de custos estabelece-se meio para especificar as atividades. Como dito anteriormente, isso pode ser feito com base na análise dos processos do negócio ou não.

Uma vez identificadas as atividades deve-se iniciar o processo de reorganização da classificação de custos, das categorias do livro razão para as categorias de atividades que, de acordo com autores, deve ser feito em duas etapas. A primeira envolve um exame geral à procura de oportunidades para condensar os dados da contabilidade. A segunda, montar uma nova arquitetura de custeio, examinando seus detalhes com base nos centros de custos.

Para isso, faz-se necessário entender a estrutura do esquema de numeração de contas, bem como o conteúdo de cada uma e esboçar um mapa organizacional com base nas informações sobre os centros de custos. Em seguida, identificar contas semelhantes para combiná-las. Uma característica salutar a ser obtida é que as combinações das contas devem obedecer aos fatores que as causam. Depois disso, deve-se combinar e estabelecer uma seqüência dos centros de custos, de modo a refletir o fluxo do processo e suas causas básicas, bem como analisar quaisquer alocações, rateios internos ou transferências de custos.

Em seguida, pregam os autores ser necessário examinar os dados de custos nos centros de custos individuais, para especificar as regras de distribuição de custos às atividades, lembrando que a seqüência ideal é o rastreamento direto, por direcionador e alocação. Depois de identificados quais centros necessitaram de direcionadores, devese especificar quais são tais "geradores de custos", terminologia utilizada pelos autores, baseada na máxima de que: "Recursos são consumidos por atividades e as atividades são realizadas para produtos ou outros objetos". Para se especificar um gerador de custos, o mesmo deve ter uma relação lógica com sua atividade e dispor de estatísticas que lhe permitam associar os custos às atividades.

Contudo Ostrenga et al. (1993) alertam:

- resistir à tentação de chamar alguma coisa de gerador de custo somente por dispor de dados a respeito dela,

- ao considerar alternativas de geradores, pondarar o custo relativo da coleta de dados em relação à precisão relativa que cada um ofereceria, e 
- enquanto estiver tomando decisões a respeito de geradores, certificar-se de receber contribuições de pessoas diretamente envolvidas nas atividades. Envolva essas pessoas mesmo que não sejam membros permanentes da equipe.

Uma vez especificados os geradores, necessita-se colher informações a respeito da quantidade de cada gerador associado às atividades que serão custeadas. Leva-se o custo dos recursos a cada grupo de custos, através da multiplicação, do que Ostrenga et al. (1993) chamam de índice de custeio de recursos, pelo respectivo fator de consumo de recursos.

Depois de definidos os centros de custos, deve-se custear os objetos através das atividades consumidas pelos mesmos. Ostrenga et al. (1993) fornecem cinco passos para isso.

Depois de definido um gerador para cada grupo de custos de atividades, necessita-se coletar ou desenvolver dados a respeito de cada gerador para cada objeto, de tal modo que representem, de forma conveniente, as demandas que um objeto faz, em relação aos outros, sobre cada atividade. Em seguida, deve-se realizar a execução dos cálculos, levando-se os recursos das atividades aos objetos.

Escolhe-se este ponto da descrição para dar lume ao método de custeio baseado em atividades adotado, através do exemplo utilizado no guia.

O processo abordado no exemplo é o manuseio de materiais, um processo que se inicia quando o material é recebido e termina quando é lançado contra uma ordem de produção ou de venda, e está localizado, principalmente, no departamento de Recebimento e Suprimentos, com exceção da atividade de inspeção do departamento de Garantia de Qualidade. A Figura 32 demonstra as atividades, já agrupadas, ao longo do tempo envolvidas no processo. 


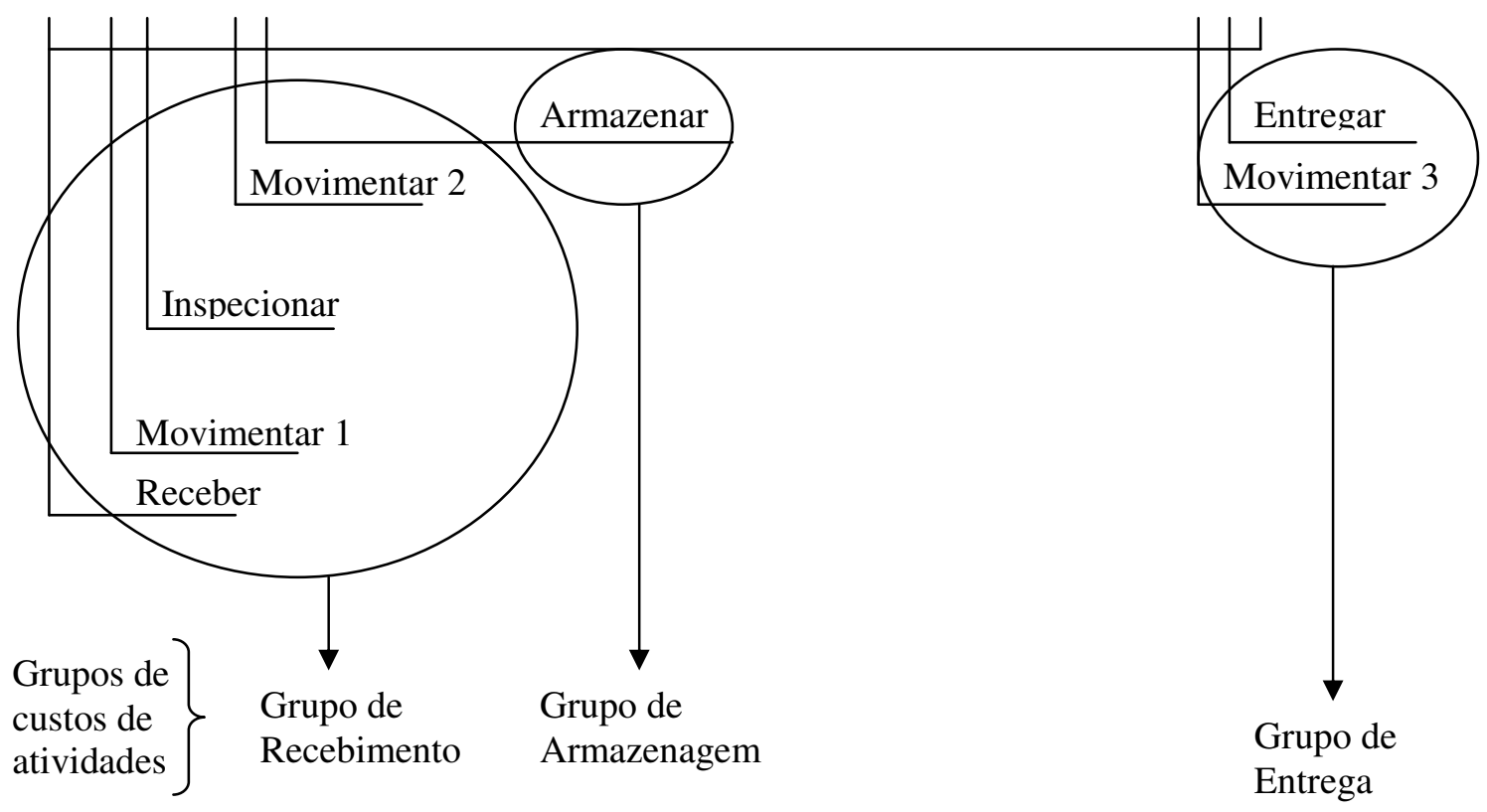

Figura 32 : Linha do tempo do processo de manuseio de materiais do recebimento à entrega Fonte: Ostrenga et al. (1993, p.194)

A Figura 33 informa os custos do livro contábil para os departamentos de Garantia da Qualidade e de Recebimento e Suprimento, bem como os geradores de custos para cada custo.

\begin{tabular}{|c|c|c|c|}
\hline \multirow{6}{*}{$\begin{array}{l}\text { Folha de pagamento } \\
\text { Encargos sobre folha } \\
\text { Benefícios } \\
\text { Viagens } \\
\text { Suprimentos }\end{array}$} & \multirow{2}{*}{$\begin{array}{l}\text { Garantia de Qualidade } \\
\quad \text { (US\$) } \\
\quad 210.000\end{array}$} & \multicolumn{2}{|c|}{$\begin{array}{l}\text { Recebimento de Suprimentos } \\
\text { (US\$) }\end{array}$} \\
\hline & & 350.000 & \\
\hline & $21.000\}$ empregados & 35.000 & $\begin{array}{l}\text { N de } \\
\text { empregados }\end{array}$ \\
\hline & 42.000 & 70.000 & \\
\hline & 30.000 & 0 & \\
\hline & $\begin{array}{ll}6.000 & \mathrm{~N}^{\circ} \text { de } \\
\text { empregados }\end{array}$ & 10.000 & \\
\hline Subtotal & 309.000 & 465.000 & \\
\hline Cobranças por ocupação & $25.000 乙 \mathrm{~N}^{\circ} \mathrm{de}$ & 500.000 & Área \\
\hline Cobranças pelo SIG & $8.000 \Im$ empregados & 40.000 & $\mathrm{~N}^{\mathrm{o}}$ de terminais \\
\hline $\begin{array}{l}\text { Depreciação de } \\
\text { equipamento }\end{array}$ & 14.000 & 200.000 & Área \\
\hline Total & 356.000 & 1.205 .00 & \\
\hline
\end{tabular}

Figura 33 : Identificação de determinantes de recursos para os departamentos Fonte: Ostrenga et al. (1993, p.185)

Na Figura 34, apresentam-se os fatores de consumo de recursos das atividades. 


\begin{tabular}{|c|c|c|c|}
\hline & \multicolumn{3}{|l|}{ Garantia de Qualidade } \\
\hline Atividade & \multicolumn{3}{|l|}{ Número de empregados } \\
\hline Inspeção & \multicolumn{3}{|l|}{4} \\
\hline Prevenção & \multicolumn{3}{|l|}{3} \\
\hline Total & \multicolumn{3}{|l|}{7} \\
\hline & \multicolumn{3}{|c|}{ Recebimento e Suprimentos } \\
\hline & Número de empregados & $\mathrm{M}^{2}$ & $\mathrm{~N}^{\mathrm{o}}$ de Terminais \\
\hline \multicolumn{4}{|l|}{ Atividade } \\
\hline Receber & 4 & 90 & 2 \\
\hline Movimentar - 1 & 2 & & \\
\hline Movimentar - 2 & 1 & & \\
\hline Armazenar & 4 & 1350 & 2 \\
\hline Movimentar - 3 & 1 & & \\
\hline Entregar & 2 & 67 & 1 \\
\hline Total & 14 & 1507 & 5 \\
\hline
\end{tabular}

Figura 34 : Fatores de consumo de recursos

Fonte: Ostrenga et al. (1993, p.186)

Assim, pode-se calcular os índices de custeio de recursos para os departamentos, de acordo a Figura 35, abaixo.

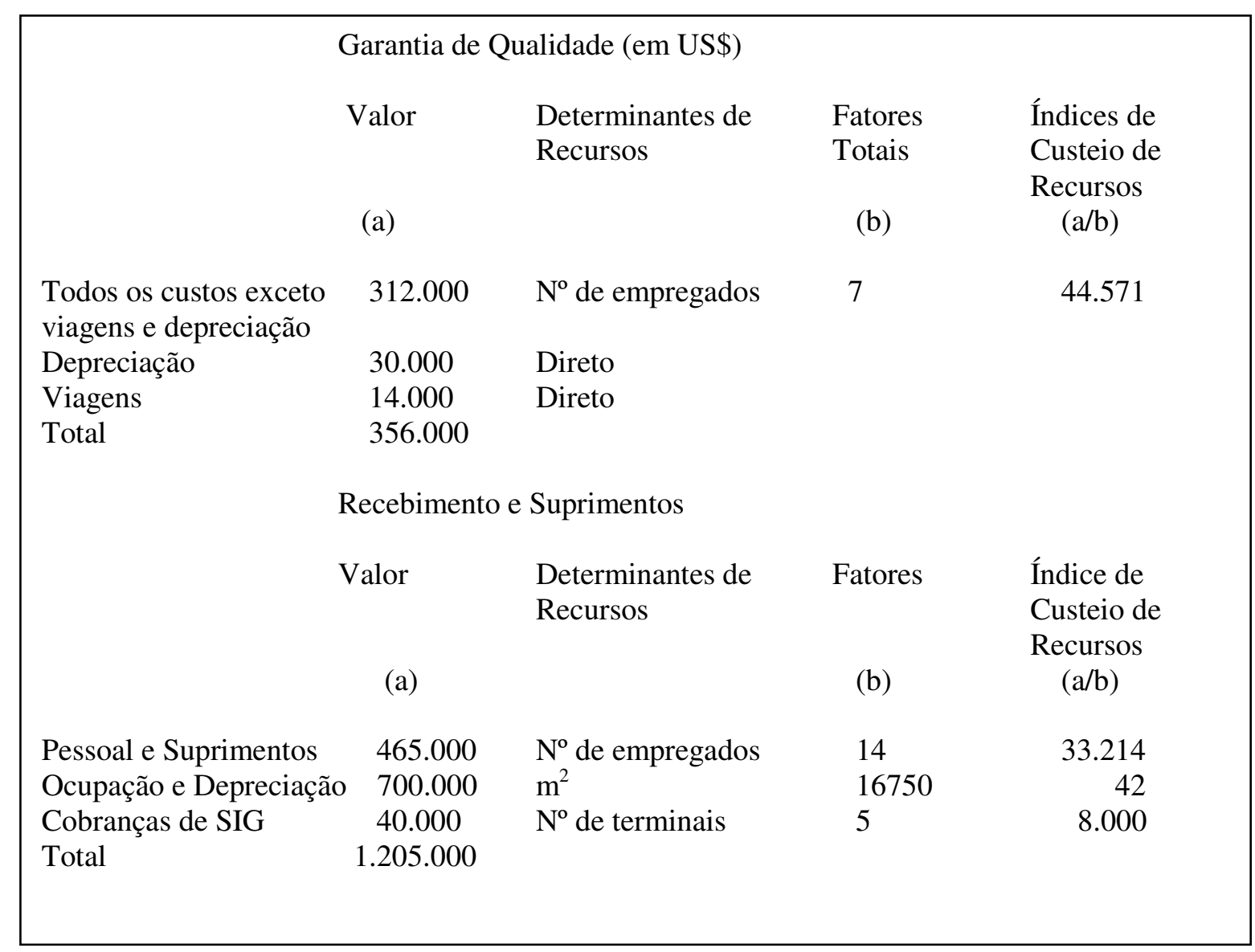

Figura 35 : Cálculo de índices de custeio de recursos para os departamentos Fonte: Ostrenga et al. (1993, p.187) 
No exemplo, o índice de custeio de recursos para pessoal e suprimentos no centro de custos de recebimento de suprimento é de 33.214,29 dólares (465.000 dólares de custos divididos pelo total de funcionários no centro de custos, de 14 ETIs equivalentes de tempo integral). Para distribuir esses recursos para as atividades, devese multiplicar o índice de custeio de recursos pelo respectivo fator de consumo de recursos. Como mostra a Figura 36.

\begin{tabular}{|c|c|c|c|c|c|c|}
\hline \multicolumn{7}{|c|}{ Custos de Atividades (em US\$) } \\
\hline \multicolumn{2}{|c|}{ Departamento de Qualidade } & \multicolumn{2}{|c|}{ Inspeção } & \multicolumn{2}{|l|}{ Prevenção } & \\
\hline \multicolumn{3}{|c|}{ Todos os custos exceto viagens } & 178.286 & \multicolumn{2}{|l|}{133.714} & \\
\hline \multicolumn{2}{|l|}{ Viagens } & & \multicolumn{2}{|c|}{30.000 (Parte-1) } & \\
\hline \multicolumn{2}{|c|}{ Depreciação de Equip. } & \multicolumn{2}{|c|}{14.000} & \multicolumn{2}{|l|}{163.714} & \\
\hline \multicolumn{7}{|c|}{ Departamento de Recebimento e Suprimentos } \\
\hline & Receber & Mov.1 & Mov. 2 & Armazenar & Mov. 3 & Entregar \\
\hline Pes. e Supr. & 132.857 & 66.429 & 33.214 & 132.857 & 33.214 & 66.429 \\
\hline Ocup. e Depr. & 41.791 & & & 626.866 & & 31.343 \\
\hline Cobr. SIG & 16.000 & & & 16.000 & & 8.000 \\
\hline Total & 190.648 & 66.429 & 33.214 & 775.723 & 33.214 & 105.772 \\
\hline
\end{tabular}

Figura 36 : Reorganização de custos da contabilidade para atividades Fonte: Ostrenga et al. (1993, p. 188)

Formados os grupos de atividades, chega-se ao custo de cada grupo, como na Figura 37. 


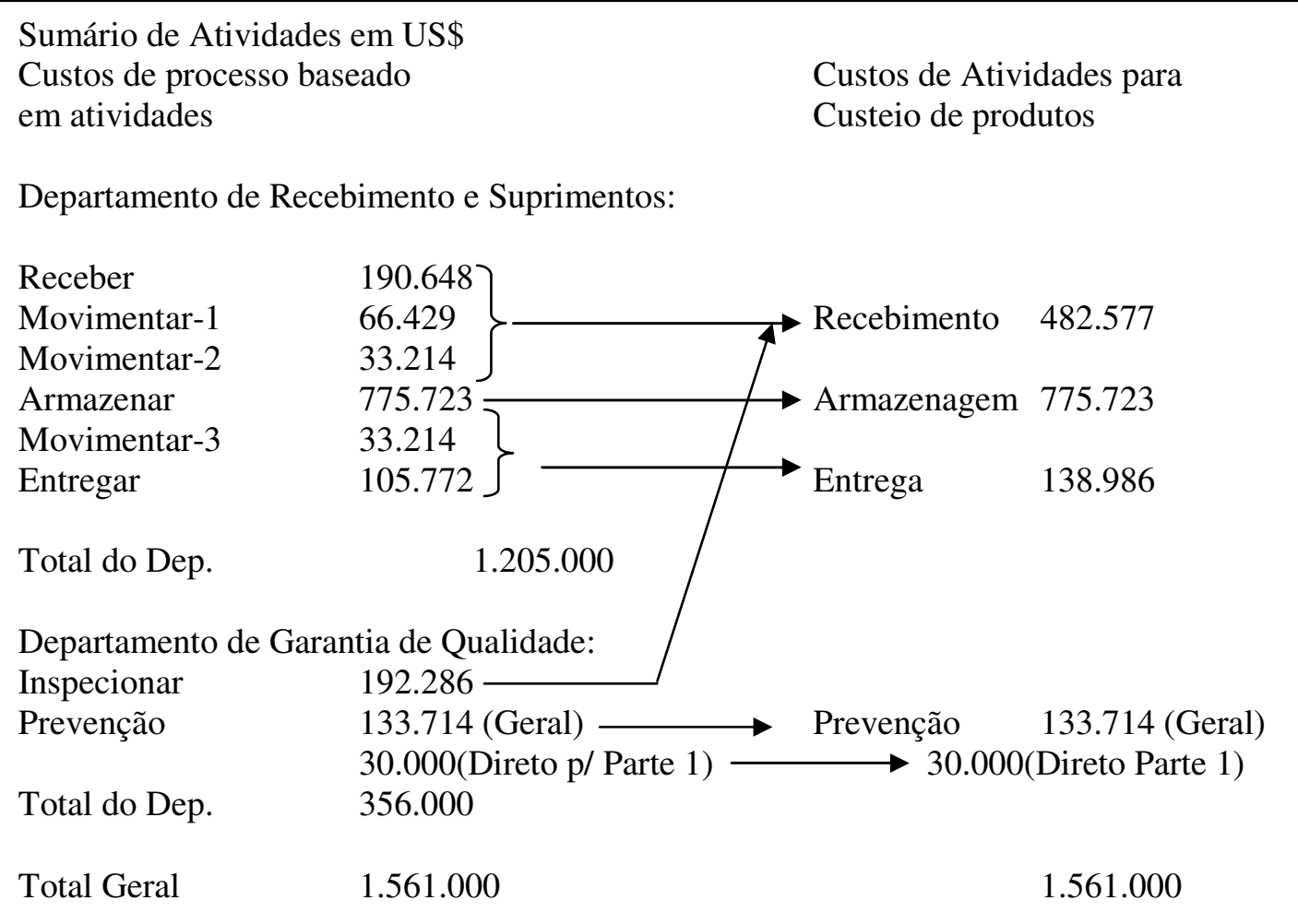

Figura 37 - Consolidação das atividades para custeio baseado em atividades Fonte: Ostrenga et al. (1993, p. 195)

Os geradores de custos utilizados neste exemplo para atribuição dos custos aos produtos estão mostrados na Tabela 4.

Tabela 4 : Geradores de custos

\begin{tabular}{ll}
\hline Atividades & Gerador de custo \\
\hline Recebimento & Número de Transações de Recebimento \\
\hline Armazenagem & $\begin{array}{l}\text { Fator ponderado incluindo: } \\
\text { Valor médio de estoque e do suprimento } \\
\text { em dias }\end{array}$ \\
\hline Entrega & Número de transações de entrega \\
\hline Prevenção & Custo padrão de mão-de-obra \\
\hline
\end{tabular}

Fonte: Ostrenga et al. (1993)

Na Figura 38 demonstram-se os fatores de consumo das atividades do exemplo, depois de coletados os dados relativos às demandas de cada objeto (produtos e peças), sobre cada atividade. 


\begin{tabular}{|c|c|c|c|c|c|}
\hline & $\begin{array}{l}\mathrm{N}^{\circ} \text { de } \\
\text { Transações } \\
\text { de } \\
\text { Recebimento }\end{array}$ & $\begin{array}{l}\text { Estoque } \\
\text { médio }\end{array}$ & $\begin{array}{l}\text { Suprimento } \\
\text { em dias }\end{array}$ & $\begin{array}{l}\mathrm{N}^{\circ} \text { de } \\
\text { Transações } \\
\text { de Entrega }\end{array}$ & $\begin{array}{l}\text { Custo Padrão } \\
\text { Mão-de-Obra }\end{array}$ \\
\hline FG-1 & & & & 100 & $\$ 0,50$ \\
\hline FG-2 & & & & 30 & 0,15 \\
\hline FG-3 & & & & 25 & 0,15 \\
\hline FG-4 & & & & 125 & 0,20 \\
\hline Parte - 1 & 50 & $\$ 22.500$ & 3 & & \\
\hline Parte - 2 & 125 & 66.000 & 2 & & \\
\hline Parte - 3 & 25 & 40.000 & 6 & & \\
\hline Parte - 4 & 15 & 3.500 & 18 & & \\
\hline Parte - 5 & 10 & 2.000 & 25 & & \\
\hline
\end{tabular}

Figura 38 : Fatores de consumo das atividades

Fonte: Ostrenga et al. (1993)

A fictícia empresa do exemplo fabrica quatro produtos: FG-1, FG-2, FG-3 e FG-4, à partir de cinco peças: Parte - 1, Parte - 2, Parte - 3, Parte - 4 e Parte - 5. A Figura 39 ilustra a formação de cada produto.
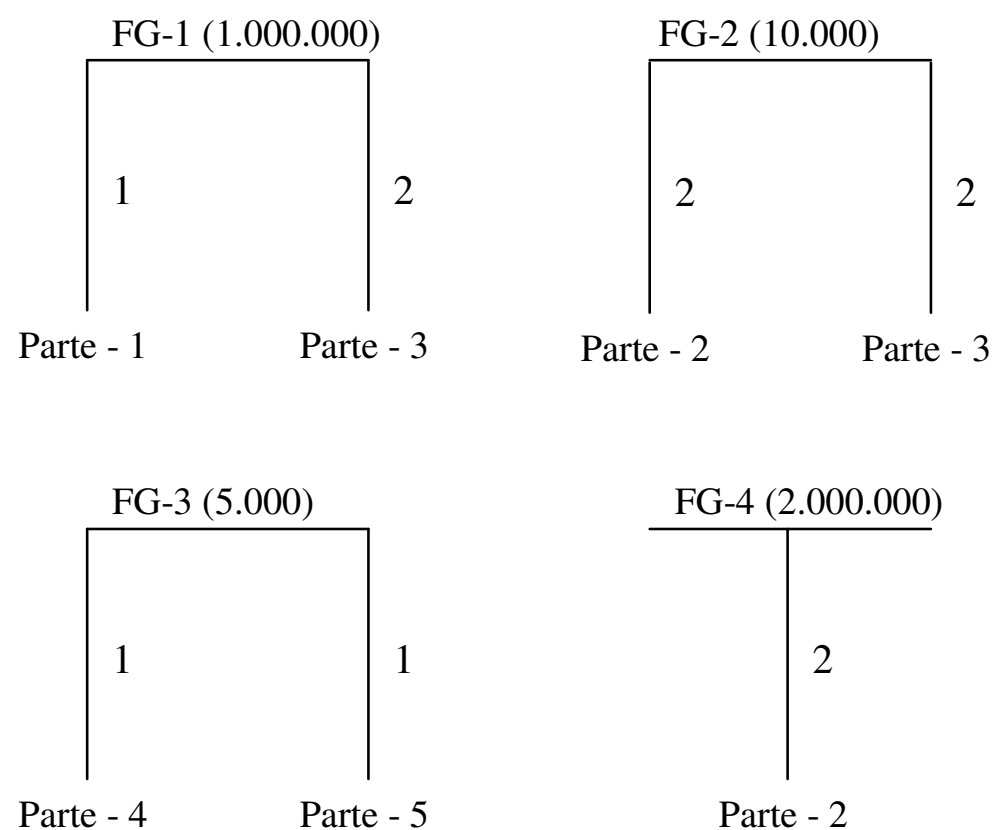

Parte - 4

Parte - 5

Parte - 2

Figura 39 : Lista de materiais

Fonte: Ostrenga et al. (1993)

Os números entre parênteses indicam a produção total anual dos quatro produtos. Exemplificando, a produção anual total de FG-1 é de 1.000.000. As linhas verticais indicam componentes. O produto FG-1 é montado a partir de duas partes 
compradas (Parte-1 e Parte-3). Os números à direita das linha verticais indicam quantos componentes são necessários para se fazer um dos produtos acabados. Ainda:

- FG-1 e FG-4 são produtos de alto volume, que a empresa produz quase constantemente;

- FG-2 e FG-3 são produtos de baixo volume, feitos à medida que é necessário atender a pedidos específicos dos clientes;

- FG-2 usa os mesmos componentes que são usados nos produtos de alto volume;

- FG-3, por outro lado, é feito de componentes exclusivos.

De posse de todos os dados necessários à distribuição dos custos das atividades aos produtos, resta apenas calcular o índice de custeio de atividades e aplicálo aos itens individuais. Como elucida a Figura 40, abaixo:

\begin{tabular}{|cccc|}
\hline \multicolumn{3}{l}{ Custos de Recebimento em US\$ } & \\
\multirow{4}{\$}{ N82.577 } & No de Recebimentos & Custo ABC \\
& Parte 1 & 50 & $\$ 107.239$ \\
& Parte 2 & 125 & 268.098 \\
& Parte 3 & 25 & 53.620 \\
& Parte 4 & 15 & 32.172 \\
& Parte 5 & 10 & 21.448 \\
Total & 225 & $\$ 482.577$
\end{tabular}

Índice de Custeio da Atividade: \$ 2.144,79

Custos de Armazenagem

\begin{tabular}{|c|c|c|}
\hline \multirow[b]{2}{*}{$\$ 775.723$} & \multicolumn{2}{|r|}{ Valor médio } \\
\hline & Parte 1 & $\$ 22.500$ \\
\hline & Parte 2 & 66.000 \\
\hline & Parte 3 & 40.000 \\
\hline & Parte 4 & 3.500 \\
\hline & Parte 5 & 2.000 \\
\hline & Total & \\
\hline
\end{tabular}

$\begin{array}{cccc}\text { Supr. em dias } & \text { Peso } & \text { Percentual } & \text { Custo ABC } \\ 3 & 67.500 & 12,22 \% & \$ 94.772 \\ 2 & 132.000 & 23,89 \% & 185.331 \\ 6 & 240.000 & 43,44 \% & 336.966 \\ 18 & 63.000 & 11,40 \% & 88.453 \\ 25 & 50.000 & 9,05 \% & 70.201 \\ & 552.500 & 100 \% & \$ 775.723\end{array}$

Custos de Entrega

$\begin{array}{lll} & \mathrm{N}^{\mathrm{o}} \text { de Entregas } & \text { Custo ABC } \\ \text { FG-1 } & 100 & \$ 49.638 \\ \text { FG-2 } & 30 & 14.891 \\ \text { FG-3 } & 25 & 12.409 \\ \text { FG-4 } & 125 & 62.047 \\ \text { Total } & 280 & \$ 138.986\end{array}$

Índice de Custeio da Atividade: \$ 496,38

Figura 40 : Índices de custeio de atividades e alocações

Fonte: Ostrenga et al. (1993) 
Assim, chega-se aos custos indiretos dos objetos através do custeio baseado em atividades, Figura 41:

\begin{tabular}{|c|c|c|c|c|c|c|c|}
\hline \multicolumn{8}{|c|}{ Custos Indiretos Totais do ABC em US\$ } \\
\hline & $\begin{array}{l}\text { Recebi } \\
\text { mento }\end{array}$ & $\begin{array}{l}\text { Armaze } \\
\text { nagem }\end{array}$ & $\begin{array}{l}\text { Entre } \\
\text { ga }\end{array}$ & Prevenção & Total & Uso anual & $\begin{array}{l}\text { Custo } \\
\text { unitário }\end{array}$ \\
\hline Parte 1 & $\$ 107.239$ & $\$ 94.772$ & & $\$ 30.000$ & $\$ 232.011$ & 1.000 .000 & $\$ 0,23$ \\
\hline Parte 2 & 268.098 & 185.331 & & & 453.429 & 4.020 .000 & 0,11 \\
\hline Parte 3 & 53.620 & 336.966 & & & 390.586 & 2.020 .000 & 0,19 \\
\hline Parte 4 & 32.172 & 88.453 & & & 120.625 & 5.000 & 24,13 \\
\hline Parte 5 & 21.448 & 70.201 & & & 91.649 & 5.000 & 18,33 \\
\hline FG-1 & & & 49.638 & & 49.638 & 1.000 .000 & 0,05 \\
\hline FG-2 & & & 14.891 & & 14.891 & 10.000 & 1,49 \\
\hline FG-3 & & & 12.409 & & 12.409 & 5.000 & 2,48 \\
\hline FG-4 & & & 62.047 & & 62.047 & 2.000 .000 & 0,03 \\
\hline Total & 482.577 & 775.723 & 138.985 & & 1.427.285 & 9.065 .000 & \\
\hline
\end{tabular}

Figura 41 : Custos Indiretos Totais do ABC

Fonte: Ostrenga et al. (1993)

Depois de calculados os custos, pode-se realizar diferentes inferências relativas aos índices de custeio, aos objetos e às atividades em si. Neste exemplo, notase que, a cada vez que um carregamento de matérias-primas é recebido, gasta-se mais de 2.000 dólares. Dados como este auxiliam a direcionar variáveis do sistema de indicadores de desempenho e práticas orçamentárias da empresa rumo a abordagem por atividades. O principal uso das informações obtidas pelo método de custeio baseado em atividades engendra comparações com custos obtidos pelo sistema tradicional ou por absorção.

Contudo mero cálculo não promove ação de melhoria.

Uma vez concluídos os seus cálculos, você deve voltar a atenção para decisões importantes e como as novas informações de custos podem afetá-las. A pergunta crítica é: 'Como uso os resultados de nossa perspectiva de ABC para melhorar o desempenho da empresa?' Tenha em mente que você precisará agir para reduzir seus custos totais e/ou elevar sua receita total, antes que o projeto de $\mathrm{ABC}$ tenha algum efeito sobre seus lucros. (OSTRENGA et al., 1993, p.224)

E ressaltam:

Em quase todos os casos, os custos $\mathrm{ABC}$ precisam ser interpretados como custos de médio e longo prazo. Raramente devem ser interpretados como custos que variam com o volume a curto prazo. É apropriado usar os custos $\mathrm{ABC}$ para:

1. compreender o que causa custos em sua empresa; e 
2. avaliar a lucratividade relativa de serviços, processos, produtos, clientes e assim por diante. (OSTRENGA et al.., 1993, p.224)

Sobretudo, ao fim das explanações sobre o método de custeio baseado em atividades os autores deixam clara a marca de junção entre a visão por atividades (processos) e o pensamento enxuto.

Ao constatar que essas atividades de preparo e limpeza (atividades relacionadas a lote) são tão dispendiosas, você pode reagir apressadamente e sugerir que o trabalho seja processado em lote menos freqüentes, porém maiores. $\mathrm{Na}$ verdade, você poderá ser tentado a usar as fórmulas para o cálculo de 'lotes econômicos' ao formalizar sua recomendação. Caso você esteja se inclinando para uma recomendação desse tipo, pare! [...] O pessoal de operações passou os últimos 10 anos aprendendo a enfatizar a redução dos custos de ajuste e desenfatizar [sic] os lotes econômicos. (OSTRENGA et al.., 1993)

Acenam para o custeio meta, ou custeio alvo, quando afirmam: “[...] Da mesma forma, os resultados de uma análise $\mathrm{ABC}$ podem ser fornecidos às equipes de engenharia de projeto para capacitá-las a projetar para a lucratividade" (OSTRENGA et al., 1993).

E ainda declaram:

[...] Um dos usos mais importantes das informações do ABC é o foco que podem dar aos programas de melhoria contínua. [...] Estas informações não lhe dizem como corrigir um problema ou como fazer melhoramentos operacionais. Mas elas acrescentam a estrutura e a relatividade necessárias à fixação de prioridades e metas para áreas específicas. [...] As informações do $\mathrm{ABC}$ voltam à cena quando você monitora os resultados dos seus esforços de aperfeiçoamento (OSTRENGA et al., 1993, p.229-2230)

\subsubsection{Implementação da Gestão Total dos Custos (TCM - Total Cost Management)}

Finda a abordagem relativa à melhoria contínua, não elucidada aqui por motivo de foco, os autores dedicam um capítulo à implementação do método de gestão total dos custos proposto. Perfazem tópicos sobre limitações, projetos pilotos, escopo de aplicação, questões ligadas a software e organização do esforço do TCM (Total Cost Management - Gestão Total dos Custos) e recomendam: 
Em primeiro lugar, suas informações de custos devem apoiar sua estratégia.[...] Em segundo lugar, você deve tentar ver sua organização como um conjunto de processos e não como um conjunto de funções. [...] Em terceiro lugar, uma vez mudada a sua percepção da empresa, você deve gerenciar os custos através da gestão das atividades. [...] Em quarto lugar, você deve organizar as informações identificando o valor das atividades para seus clientes. [...] Em quinto lugar, as constatações das suas análises do TCM devem entrar nos planos de ação. [...] Finalmente, você precisa monitorar sua empresa re-alinhando os indicadores de desempenho com os fatores críticos de sucesso que tiver identificado. (OSTRENGA et al., 1993, p.319)

Destas recomendações, caso adotadas, advém uma mudança de mentalidade e bases gerenciais sustentáveis pelos métodos do TCM. Entrementes declaram Ostrenga et al. (1993):

Uma estratégia de implementação do TCM é o meio para este fim: um plano para a seleção do projeto ou projetos iniciais e depois levar o TCM dos projetos iniciais para informações rotineiras e dos fluxos principais da empresa.

Tais planos iniciais, ou projetos piloto, prestam-se para fundar um projeto conceitual e fornecer recursos para projetos futuros. Um projeto piloto é limitado no escopo, trata de uma decisão de negócio atual e é conduzido como um projeto "fora de linha", pontualmente identificando

- quais técnicas do TCM devem ser incluídas de acordo a realidade da empresa;

- se os dados são coletados e organizados para apresentação dentro de um projeto especial, ou se são executados como parte do processamento cotidiano de informações baseadas em transações;

- se os custos baseados em atividades, calculados para análise gerencial, estão integrados ou não com os custos usados para os relatórios financeiros;

- que processos serão incluídos no escopo do piloto;

- outros fatores limitantes;

- o referencial de tempo para implementação, cronograma;

- quem irá realizar cada tarefa. 
Quanto às questões de software, Ostrenga et al. (1993) consideram mais eficiente conduzir projetos piloto usando uma combinação de opções de software que requerem apenas um investimento mínimo ou nulo em novas ferramentas, deixando para o final dos projetos a definição da arquitetura de sistema usada na passagem à implementação em escala mais ampla. Observando que não se deve considerar o software um impedimento à condução do piloto do TCM, de fato a seleção do software deve ser vista como de pouco importância.

Porém, concluídos os projetos piloto, existirão informações necessárias para finalizar os requisitos do sistema e desenvolver um plano de software dentro da estratégia global do TCM. Para planejar o software de modo a acompanhar a evolução do projeto de TCM existem três abordagens básicas:

1. baseada no uso de pacotes que não alterem os sistemas atuais,

2. desenvolvimento sob medida,

3. combinação das duas primeiras.

Olhando-se o plano de implementação como um todo, a organização do esforço do TCM pode ser dividida em quatro estágios: garantir patrocínio, organizar o projeto, executar o projeto e agir em função dos resultados do projeto.

O primeiro estágio finda quando o executivo patrocinador do trabalho do TCM frui de visão suficientemente clara sobre os benefícios do TCM e compreende quais recursos são necessários à formação de uma equipe de projeto, para levar o trabalho até o nível detalhado de análise.

Organizar o projeto inclui definir o objetivo e o escopo, nomear um líder, montar uma equipe através da designação de atribuições para as pessoas envolvidas e autorizar quaisquer outros recursos para o projeto.

De resto, Ostrenga et al. (1993, p.324) alertam:

A estratégia de implementação precisa considerar aspectos da disposição da organização para mudar e trabalhar para assegurar que ela será capaz de efetuar as mudanças previstas a partir da série de projetos do TCM. 
Adiante serão descritas algumas abordagens diversas da anterior, no intuito de enriquecer as investigações. Tais abordagens de custos direcionadas para a logística de distribuição perfazem as idéias levantadas nos capítulos anteriores.

\subsection{Outras abordagens}

\subsubsection{Capacidade e tempo}

Em seu artigo, Kaplan e Anderson (2003) propõem um diferente modo de implementação do ABC, direcionado pelo tempo. Tal proposta abarca maior heterogeneidade nas atividades, pedidos e comportamento dos consumidores, sem causar onerosas demandas para calcular os custos de atividades, produtos e consumidores. Para crédito de suas idéias, iniciam demonstrando as dificuldades de implementação do modelo tradicional do ABC.

$\mathrm{O}$ modelo $\mathrm{ABC}$ tradicional tem sido difícil de implementar para muitas organizações devido aos altos custos incorridos em entrevistar e avaliar pessoas para o modelo ABC inicial, ao uso de alocações subjetivas e difíceis de avaliar, e a dificuldade de manter e atualizar o modelo enquanto (i) processos e recursos gastos mudam, (ii) novas atividades são adicionadas, e (iii) ocorrem aumentos na diversidade e complexidade de pedidos individuais, canais e consumidores. (KAPLAN e ANDERSON, 2003, p.1, tradução nossa).

Em suma, resumem os autores, o processo de calcular custos das atividades por entrevistas, observações e avaliações tem provado ser laborioso e custoso para coletar dados, dispendioso para armazenar, processar e reportar, difícil de atualizar, em vista das mudanças de circunstâncias e teoricamente incorreto, pela supressão do papel da capacidade inutilizada quando calculando taxas de direcionadores de custos.

Tais taxas (divisão entre os gastos da atividade ou transação e o número de vezes que é realizada) possuem, implicitamente, a idéia de que cada vez que a transação ou atividade é realizada consome a mesma quantidade de recursos, o que nem sempre é verossímil. Para corrigir este fato, Kaplan e Anderson (2003) sugerem duas estimativas adicionais:

1. o custo unitário da capacidade supridora ou fornecedora, e

2. o consumo da capacidade (unidades de tempo) pelas atividades realizadas pela empresa para produtos, serviços e consumidores. 
Para calcular-se o custo unitário da capacidade supridora, inicialmente deve-se medir a capacidade real, frequentemente entre 80 e $85 \%$ da capacidade teórica. Uma alternativa simples para estimar-se a capacidade real é rever as séries temporais dos níveis da atividade. Por exemplo, verificar o número de pedidos de clientes manuseadas nos últimos 12 ou 24 meses e identificar o mês com o máximo número de pedidos. Checar se, naquele período, o trabalho foi feito sem atrasos excessivos, qualidade pobre, horas extras, ou empregados pressionados. Se não, como ponto de partida, usar aquele número máximo como estimativa da capacidade dos recursos desempenhados naquela atividade.

Ressalvam os autores que, como todas as decisões de projeto $\mathrm{ABC}$, tal análise não é muito sensível a pequenos erros quando se estimam os parâmetros acima descritos. O objetivo é ser aproximadamente correto pois, caso a estimativa esteja errada, o processo cursivo do sistema $\mathrm{ABC}$ dirigido pelo tempo revelará o erro. Depois de estimados (i) o custo da atividade supridora e (ii) a capacidade real, calcula-se o custo unitário da capacidade supridora como:

\section{Custo unitário $=\frac{\text { Custo da capacidade sup ridora }}{\text { Capacidade real de recursos supridos }}$}

Seguindo-se o método para estimar-se as unidades de tempo consumidas pela atividade, pode-se realizar a observação direta ou entrevistas. Novamente, precisão não é crítica, aproximação acurada é suficiente. Numericamente, fornecem os autores o seguinte exemplo.

Considere-se um departamento de serviço ao cliente que realiza três atividades: manusear pedidos dos clientes, processar queixas de clientes e checar crédito de clientes. Para realizar tais atividades tem-se \$ 560000 de custos em um trimestre. Suponha-se que, através de entrevistas, descobriu-se que os empregados estimam que $70 \%$ de seu tempo seja dedicado a manusear pedidos, $10 \%$ a processar queixas e $20 \%$ a checar crédito dos clientes. As quantidades de trabalho no trimestre destas três atividades foram: 9800 pedidos, 280 queixas e 500 checagens de crédito.

Baseando-se nestes dados, pode-se calcular os custos das atividades pelo modelo tradicional do ABC, como mostra a Tabela 5 
Tabela 5 : Custos das atividades - modelo tradicional

\begin{tabular}{lcccc}
\hline \multicolumn{1}{c}{ Atividade } & $\%$ & $\begin{array}{c}\text { Custos } \\
\text { atribuídos }\end{array}$ & $\begin{array}{c}\text { Direcionador de } \\
\text { quantidade }\end{array}$ & $\begin{array}{c}\text { Taxa } \\
\text { direcionadora }\end{array}$ \\
Manusear de pedidos & 70 & $\$ 392000$ & 9800 & $\$ 40 /$ pedido \\
Processar queixas & 10 & 56000 & 280 & $\$ 200 /$ queixa \\
Checar crédito & 20 & 112000 & 500 & $\$ 224 /$ checagem \\
Total & 100 & $\$ 560000$ & & \\
\hline
\end{tabular}

Fonte: Kaplan e Anderson (2003)

Pelo método de custeio baseado em atividades dirigido pelo tempo, deve-se, primeiramente, calcular o custo unitário da atividade supridora. Assuma-se que 28 empregados trabalham no departamento. Cada um destes fornece 10560 minutos por mês ou 31680 minutos por trimestre. A capacidade real é de aproximadamente $80 \%$ da teórica, o que significa 25000 minutos fornecidos por empregado por trimestre, ou seja, 700000 minutos de trabalho fornecido pelo departamento. O custo unitário (por minuto) da capacidade supridora é de:

Custo por $\min u t o=\frac{\$ 560000}{700000}=\$ 0,80$ por $\min u t o$

Adicionalmente, estimando-se as unidades de tempo para as três atividades do departamento, tem-se para manuseio de pedidos, 40 minutos para processar queixas, 220 minutos, e para checar créditos, 250 minutos. Com estes dados, pode-se calcular a taxa dos direcionadores de custos, como demonstra a Tabela 6.

Tabela 6 : Custos das atividades - modelo dirigido pelo tempo

\begin{tabular}{lcc}
\hline & Direcionador de custos das atividades \\
\hline Atividade & Unidades de tempo (minutos) & Taxa $@ \$ 0,80 /$ minuto \\
Manusear pedidos & 40 & $\$ 32$ \\
Processar queixas & 220 & $\$ 176$ \\
Checar crédito & 250 & $\$ 200$ \\
\hline
\end{tabular}

Fonte: Kaplan e Anderson (2003)

Esta análise revela que apenas 83\% da capacidade real (578 600/700 000) dos recursos fornecidos durante o período foram usados para trabalho produtivo (e por consequiência apenas $83 \%$ do total dos custos \$560 000 são atribuídos aos consumidores durante este período). O sistema tradicional de ABC superestima os custos de realização das atividades porque sua distribuição dos esforços, prospectados 
via entrevista ou verificação, incorpora ambos os custos de recursos de capacidade utilizada e custos de recursos não usados. Especificando o tempo para realizar cada atividade, a organização possui informações sobre custos e sobre a eficiência de cada atividade, bem como a quantidade (121 400 horas) e custos (\$ 97 120) de capacidade não usada em recursos fornecidos para realizar as atividades.

Apesar de trilharem a temerária senda da eficiência versus ética, ressalvam os autores:

Antes de reduzir a capacidade inutilizada corrente, gerentes podem escolher reservar esta capacidade para crescimento futuro. Enquanto gerentes contemplam novas introduções de produtos, expansões em novos mercados, ou apenas aumentos na demanda de produtos, eles podem prever quanto este aumento pode ser absorvido pela capacidade existente, e quando prováveis deficiências de capacidade irão requerer gastos adicionais para absorver o aumento da demanda. (KAPLAN e ANDERSON, 2003, p. 9, tradução nossa)

Os autores abordam também o fato de que nem todos os pedidos são iguais e requerem o mesmo tempo de processamento. Em relação a este problema, afirmam que, geralmente, pode-se predizer as causas que fazem com que as transações sejam mais simples ou mais complexas. Exemplificam com a atividade de embalar um produto químico para embarque. Se o item é padrão em um pacote padrão, a operação toma apenas 0,5 minuto. Se o item requer um pacote especial, então 6,5 minutos adicionais são requeridos. E se o item é para ser embarcado por ar, 0,2 minuto adicional são requeridos para colocá-lo num saco plástico.

Mais do que definir uma atividade separada para cada possível combinação de características de embarque, ou usar um direcionador de duração para cada possível combinação de embarque, o método direcionado pelo tempo estima a demanda por recursos pela simples equação:

Tempo de empacotamento $=0,5+6,5$ (caso manuseio especial requerido $)+0,2$ (caso despacho aéreo)

Os dados para manuseio especial, método de embarque, e todas as outras características de embarque tipicamente estão disponíveis no sistema ERP da empresa, em que os pedidos foram inseridos. Informações específicas do pedido permitem 
calcular rapidamente o tempo demandado por pedido através de um simples algoritmo que testa a existência de cada característica influente no tempo de embalar.

Além disso, devido à similaridade entre plantas, até mesmo empresas do mesmo ramo (indústria) permitem a construção de um acurado algoritmo baseado no tempo que possa ser utilizado por diferentes plantas da mesma empresa ou por empresas diferentes, o que permiti obter-se sistemas de custos separados e harmônicos.

Outro benefício associado à implantação do $\mathrm{ABC}$ dirigido pelo tempo reside no conhecimento gerado sobre a eficiência (custo unitário e unidades de tempo) dos processos críticos do negócio. Mais que isso, este método de implementação permite predizer as alterações nos custos através da mudança de comportamento dos clientes.

Em relação à atualização, este método de implantação permite que o modelo evolua à medida que os gerentes aprendam mais sobre a variedade e a complexidade adicionais nos processos, pedidos, fornecedores e clientes. Exemplificam os autores que na empresa Maines Paper and Foodservice, o algoritmo de tempo para o departamento de serviço ao consumidor adiciona três minutos para pedidos especiais, outros três minutos, caso um memorando de crédito seja requerido, diminui a estimativa, caso o pedido seja feito via EDI, e adiciona ou subtrai o tempo para conhecidas características de cada cliente.

Os gerentes podem facilmente atualizar as taxas dos direcionadores de atividades. Basicamente, dois fatores causam mudanças em tais taxas: mudanças nos preços dos recursos fornecidos e mudanças na eficiência da atividade. Para corrigir as mudanças devidos ao primeiro fator, basta compensar a mudança no custo unitário da capacidade supridora, caso ocorra um aumento de $8 \%$ no salário dos funcionários do departamento de serviço ao cliente; o custo unitário deve também aumentar $8 \%$ (de $\$$ 0,80 /minuto para $\$ 0,864 /$ minuto). Para corrigir as mudanças devidas ao segundo fator, os analistas de custos devem modificar as unidades de tempo estimadas.

Atestam os autores:

Seguindo este procedimento, um modelo $\mathrm{ABC}$ pode ser atualizado baseado em eventos mais do que pelo calendário (trimestralmente, ou anualmente). A qualquer tempo, analistas descobrem uma mudança significativa nos custos dos recursos fornecidos, ou mudanças nos recursos requeridos para a atividade, e atualizam as estimativas das taxas de custos. E a qualquer tempo descobrem uma mudança significativa e permanente na eficiência com a qual uma atividade é realizada, e atualizam a unidade de tempo estimada. (KAPLAN e ANDERSON, 2003, p. 11, tradução nossa) 
Incorreções nas unidades de tempo estimadas serão eventualmente reveladas tanto por excessos inesperados, quanto por faltas de recursos comprometidos. Para discernimento estratégico, estimativas com erros de até $10 \%$ são aceitáveis, porém, para controle operacional, exige-se monitoramento acurado dos recursos requeridos, da qualidade, e tempos de ciclo das atividades e processos para motivar e captar pequenos melhoramentos das atividades.

Por fim informam sobre alguns casos de implementação, cujos resultados foram:

- diminuição do número de atividades a serem gerenciadas,

- dados mais acurados para atividades e para processos complexos e heterogêneos,

- informação sobre as capacidades dos processos,

- visibilidade de custos como fundamento para políticas de aceitação de pedidos (tamanho, freqüência, serviço oferecido e análise de crédito) e políticas de vendas (comissões de vendas baseadas na lucratividade por cliente, promoção de vendas de produtos mais lucrativos).

Seguindo a mesma linha, os próximos autores reconhecem a diversidade de complexidade e tempo das atividades, porém abordam o problema de forma diversa.

\subsubsection{Categorias}

Kulmala, Paranko e Yrjänänen (2000) propõem, em seu artigo, um método para simplificar a implementação e atualização de um sistema de gestão de custos baseado em atividades. Tal simplificação é baseada em três elementos-chaves: dividir as atividades em três níveis, usar quatro categorias para o portfolio de produtos e usar a perícia dos funcionários. Assim, cada produto de uma empresa pode ser colocado em uma categoria, na qual as atividades demandadas formam uma estrutura comum.

Argumentam sobre a implementação do custeio baseado em atividades direcionado ao custeio de produtos. 
De acordo nossa experiência a fase mais difícil é a atribuição para os objetos de custos. Neste caso especialmente em custear produtos. $\mathrm{O}$ número de produtos é alto até mesmo em companhias de médio porte. O número de recursos, atividades e direcionadores variam de um par de dezenas até centenas. É a grande quantidade de produtos principal razão para a complexidade e desajeitamento dos sistemas de contabilidade. (KULMALA, PARANKO e YRJÄNÄNEN, 2000, tradução nossa)

A classificação das atividades em três níveis baseia-se no tempo em que cada atividade usa um recurso. Esse tempo pode ser detectado de modo direto ou indireto. No modo direto, entrevista-se a pessoa que exerce diretamente a atividade, no intuito de estimar-se o tempo unitário de uma atividade, ou este tempo é medido. No indireto, entrevista-se a pessoa, no intuito de descrever as atividades que perfaz e estimar o tempo relativo de cada atividade. A seguir, calcula-se o tempo unitário de uma atividade quando conhecido o tempo total do recurso. Como resultado, tem-se o tempo anual utilizado listado por atividades; de posse desse dado, pode-se calcular o tempo unitário de cada atividade, dividindo-se o tempo anual usado por atividade pelo número de atividades realizadas anualmente. Como ilustra a Figura 42, abaixo.

\begin{tabular}{|c|c|c|c|c|c|}
\hline \multicolumn{3}{|c|}{ Tempo disponível do recurso (h) } & 1600 & & \\
\hline \multicolumn{6}{|c|}{ Método indireto } \\
\hline Atividade & $\begin{array}{c}\text { Tempo relativo } \\
\text { de uso para as } \\
\text { atividades }\end{array}$ & \multicolumn{2}{|c|}{$\begin{array}{l}\text { Tempo anual } \\
\text { utilizado pela } \\
\text { atividade }(\mathrm{h})\end{array}$} & $\begin{array}{l}\text { Número de } \\
\text { atividades } \\
\text { singulares } \\
\text { realizadas no } \\
\text { ano }\end{array}$ & $\begin{array}{l}\text { Tempo unitário } \\
\text { para uma } \\
\text { atividade }(\mathrm{h})\end{array}$ \\
\hline Atividade A & $50 \%$ & & 800 & 100 & 8 \\
\hline Atividade B & $30 \%$ & & 480 & 10 & 48 \\
\hline \multirow[t]{2}{*}{ Atividade C } & $20 \%$ & & 320 & 8 & 40 \\
\hline & $100 \%$ & & 1600 & & \\
\hline
\end{tabular}

Figura 42 : Métodos diretos e indiretos para cálculo da unidade de tempo de uma atividade Fonte: Kulmala, Paranko e Yrjänänen (2000)

Ainda recomendam:

Para se checar a precisão do tempo unitário da atividade, é recomendado utilizar ambos os métodos. O método direto pode ser verificado pela adição das unidades de tempo das atividades realizadas no ano. Se o resultado está perto do tempo de recurso disponível, as unidades de tempo das atividades são confiáveis. Os resultados pelo método indireto podem ser verificados, por exemplo, 
pela simples tomada de tempo de algumas atividades, o que é basicamente igual ao método direto. Por essa razão, estes dois métodos são complementares e se suportam. (KULMALA, PARANKO e YRJÄNÄNEN, 2000, tradução nossa)

Como abordado no item 2.3.3 (Custeio Baseado em Atividades), para designar uma atividade a um objeto de custo por direcionadores de atividade, faz-se necessário definir duas variáveis: um direcionador de atividade e seu montante. Uma atividade é designada para todos os objetos de custo pelo mesmo direcionador. Porém, diferentes objetos de custo demandam diferentes montantes da atividade. A maneira convencional de definir os montantes de atividades consumidas por um objeto de custo seria tratar cada objeto de custo separadamente.

Porém o que os autores propõem é dividir as atividades em três níveis de dificuldade atribuindo pesos relativos a cada uma. Tal ação objetiva padroniza a quantidade de componentes dos direcionadores de atividades. Desse modo, não é necessário definir, separadamente, as quantidades dos direcionadores para todos os objetos de custo; essas quantidades poderiam ser escolhidas através de níveis padronizados.

Segundo os autores, os níveis podem ser formados encontrando-se as quantidades de cada atividade demandada por objeto. As quantidades deveriam ser analisadas estatisticamente no intuito de estabelecer níveis razoáveis. Tais níveis informam Kulmala, Paranko e Yrjänänen (2000), também podem ser formados entrevistando-se a melhor pessoa para estimar os direcionadores de uma atividade em uma escala que ressalte a demanda da atividade em pequena, normal e grande. Por exemplo:

“Olhando-se para atividade de faturamento, uma fatura 'rápida' pode
tomar um minuto para ser completada, uma 'normal' cinco minutos e
uma 'lenta' até mesmo meia hora. Usando este método a perícia da
pessoa que perfaz certas atividades é utilizada para minimizar
cálculos ou trabalho de medidas. O empecilho deste método jaz na
inexatidão. Todas as atividades poderiam ser niveladas por análises
específicas e entrevistas. A possível inexatidão poderia ser notada e
de algum modo até eliminada por exemplo através de análises de
sensibilidade.” (KULMALA, PARANKO e YRJÄNÄNEN, 2000,
tradução nossa)

Depois de formados os níveis e estimadas das percentagens de ocorrência de cada um, e de posse do custo anual do recurso e do tempo utilizado pela atividade no recurso, pode-se calcular o custo unitário de cada nível de atividade, como 
exemplificam os autores para atividade de aquisição, cujo direcionador é o número de posicionamentos, demonstrada na Figura 43.

\begin{tabular}{|l|l|}
\hline Ouantidade total do direcionador & 4800 \\
\hline Tempo usado para atividade pelo recurso X & $60 \%$ \\
\hline Custo anual total do recurso X & 51000 \\
\hline
\end{tabular}

\begin{tabular}{|c|r|r|r|r|r|r|r|}
\hline $\begin{array}{c}\text { Nível da } \\
\text { atividade }\end{array}$ & $\begin{array}{c}\text { Índice de } \\
\text { peso de } \\
\text { tempo } \\
\text { usado }\end{array}$ & $\begin{array}{c}\text { Percentage } \\
\text { m do nível } \\
\text { de } \\
\text { ocorrência }\end{array}$ & $\begin{array}{c}\text { Quantidade } \\
\text { do } \\
\text { direcionador }\end{array}$ & $\begin{array}{c}\text { Parcela do } \\
\text { tempo } \\
\text { utilizado } \\
\text { por cada } \\
\text { nível }\end{array}$ & $\begin{array}{c}\text { Parcela do } \\
\text { tempo total } \\
\text { usado pelo } \\
\text { recurso X }\end{array}$ & $\begin{array}{c}\text { Custo } \\
\text { anual } \\
\text { do } \\
\text { nível } \\
\text { (EUR) }\end{array}$ & $\begin{array}{c}\text { Custo } \\
\text { unitário } \\
\text { do } \\
\text { nível } \\
\text { (EUR) }\end{array}$ \\
\hline Rápido & 1 & $50 \%$ & 2400 & $7,7 \%$ & $4,6 \%$ & 2346 & 0,97 \\
Normal & 10 & $30 \%$ & 1440 & $46,2 \%$ & $27,7 \%$ & 14127 & 9,75 \\
Lento & 15 & $20 \%$ & 960 & $46,2 \%$ & $27,7 \%$ & 14127 & 14,63 \\
\hline & & $100 \%$ & 4800 & $100 \%$ & $60 \%$ & 30600 & \\
\hline
\end{tabular}

Figura 43 : Exemplo da atividade de compras - distribuição do tempo e custo Fonte: Kulmala, Paranko e Yrjänänen (2000)

O índice de peso de tempo usado representa a razão entre o tempo do nível em questão e o tempo do nível rápido. A percentagem do nível de ocorrência identifica a parte relativa da ocorrência do nível dentro da atividade. A quantidade do direcionador é encontrada pela multiplicação da parte relativa dos níveis pela quantidade total do direcionador. A parcela do tempo utilizado por cada nível é a divisão entre a quantidade do direcionador pelo tempo total da atividade (soma dos produtos entre o peso de tempo usado por nível pela quantidade do direcionador). A parcela do tempo total usado pelo recurso X informa a parcela do tempo total de trabalho do recurso usado por cada nível. O custo anual do nível é calculado pela multiplicação da parcela do tempo total usado pelo recurso X pelo custo anual total do recurso X. O custo unitário do nível é calculado pela divisão do custo anual do nível pela quantidade do direcionador do nível.

Neste caso apresentado pelos autores, os custos unitários das atividades foram designados aos objetos de custo no intuito de se averiguar a rentabilidade dos produtos. Porém, o número de produtos assim como o número de atividades mostrou-se elevado, representando um grande empecilho ao estudo. Para resolver este problema, Kulmala, Paranko e Yrjänänen (2000) criaram acintosas categorias de portfolio para os produtos, como demonstra a Figura 44: 
Itens de volume

$\checkmark \quad$ Itens comprados e vendidos continuamente;

$\checkmark$ Vários clientes;

$\checkmark$ Boa disponibilidade.

Itens baseados em ordens

Itens comprados apenas para uma ordem de um consumidor;

$\checkmark$ Usualmente um cliente;

$\checkmark$ O tempo de entrega se iguala ao tempo de entrega do fornecedor;

$\checkmark$ O consumidor precisa aceitar o tempo de entrega.
Itens baseados em prognóstico

$\checkmark \quad$ Itens com giro de estoque constante;

$\checkmark \quad$ Itens vendidos para clientes certos;

$\checkmark$ Um ou vários clientes;

$\checkmark$ Melhor disponibilidade com entregas regulares;

$\checkmark$ Contratos de segurança para estoques concebíveis.

Itens estratégicos

$\checkmark$ Armazenados por contrato de consumidor;

$\checkmark$ Um cliente ou grupo cliente;

$\checkmark$ Baixa disponibilidade sem armazenamento.

Figura 44 : As quatro categorias de portfolio implementadas na companhia do caso Fonte Kulmala, Paranko e Yrjänänen (2000)

Depois de definidas as categorias, escolheram alguns poucos produtos pilotos de cada uma das quatro e rastrearam suas estruturas de custo baseadas nas atividades. De acordo com os parâmetros de categorização, produtos da mesma categoria possuem demandas de atividades similares. Itens de volume, por exemplo, demandam, em sua maioria, atividades de compra rápidas ou normais; atividades de controle de entrega e entradas de ordens são normalmente rápidas para esses produtos. Itens baseados em prognósticos, por outro lado, demandam atividades de compra normais ou lentas, e atividades de entrada de ordens requerem mais tempo, do mesmo modo. Desta maneira, as atividades demandadas por um produto não são mais avaliadas individualmente, mas os produtos são colocados em uma classe que melhor descreve sua estrutura de atividades.

Os autores resolveram dois problemas: a necessidade de medir-se a quantidade total das atividades consumidas por cada produto, através da eleição de níveis de atividade e a necessidade de se determinar quais atividades cada produto consumiu, através da formação de classes com combinações de diferentes atividades e níveis de atividades. 
No caso apresentado, realizado em uma empresa finlandesa especializada em vendas técnicas, por atacado, de máquinas de construção, Kulmala, Paranko e Yrjänänen (2000) utilizaram quatro atividades: aquisição, controle de entrega, entrada de ordens e armazenagem. Essas quatro atividades geraram oitenta e uma $\left(3^{\mathrm{n}^{\circ}}\right.$ de atividades = 81) combinações possíveis de atividades e níveis, porém, depois de consultadas as pessoas que exerciam as atividades, esse número decresceu para dez (10) combinações significantes de atividades e níveis. Essas dez classes permitiram classificar todos os produtos com adequada precisão para suportar decisões estratégicas sobre produtos e clientes. Tais classes são demonstradas pela Figura 45.

\begin{tabular}{|l|llll|}
\hline \multicolumn{2}{|l|}{ Itens de volume } & & & \\
& & & & \\
& $\mathrm{Aq}$ & $\mathrm{Ce}$ & $\mathrm{Eo}$ & $\mathrm{Ar}$ \\
\hline Classe 1 & $\mathrm{R}$ & $\mathrm{R}$ & $\mathrm{R}$ & $\mathrm{R}$ \\
Classe 2 & $\mathrm{N}$ & - & $\mathrm{R}$ & $\mathrm{N}$ \\
Classe 3 & $\mathrm{R}$ & $\mathrm{R}$ & $\mathrm{N}$ & $\mathrm{R}$ \\
Classe 4 & $\mathrm{N}$ & $\mathrm{L}$ & $\mathrm{N}$ & $\mathrm{L}$ \\
\hline
\end{tabular}

\begin{tabular}{|l|llll|}
\hline \multicolumn{4}{|l|}{ Itens baseados em prognóstico } \\
& $\mathrm{Aq}$ & $\mathrm{Ce}$ & $\mathrm{Eo}$ & $\mathrm{Ar}$ \\
\hline Classe 5 & $\mathrm{N}$ & - & $\mathrm{L}$ & $\mathrm{L}$ \\
Classe 6 & $\mathrm{L}$ & - & $\mathrm{R}$ & $\mathrm{L}$ \\
& & & & \\
\hline
\end{tabular}

\begin{tabular}{|l|llll|}
\hline \multicolumn{5}{|l|}{ Itens baseados em ordens } \\
& $\mathrm{Aq}$ & $\mathrm{Ce}$ & $\mathrm{Eo}$ & $\mathrm{Ar}$ \\
\hline Classe 7 & $\mathrm{R}$ & - & $\mathrm{R}$ & $\mathrm{R}$ \\
Classe 8 & $\mathrm{L}$ & - & $\mathrm{L}$ & $\mathrm{R}$ \\
& & & & \\
\hline
\end{tabular}

\begin{tabular}{|l|llll|}
\hline \multicolumn{2}{|l|}{ Itens estratégicos } & & & \\
& & & & \\
& $\mathrm{Aq}$ & $\mathrm{Ce}$ & $\mathrm{Eo}$ & $\mathrm{Ar}$ \\
\hline Classe 9 & $\mathrm{~N}$ & - & $\mathrm{R}$ & $\mathrm{L}$ \\
Classe 10 & $\mathrm{~L}$ & - & $\mathrm{R}$ & $\mathrm{R}$ \\
& & & & \\
\end{tabular}

Figura 45 : Classificação dos itens por variáveis escolhidas (aquisição Aq, controle de entrega $\mathrm{Ce}$, entrada de ordens Oe, armazenagem Ar) e valores medidos (rápida R, normal N, lenta L).

Fonte Kulmala, Paranko e Yrjänänen (2000)

No entanto dificuldades foram relatadas principalmente devido ao fato dos entrevistados acharem difícil nomear os elementos que explicariam as diferenças de tempo entre os níveis de atividade. Além disso, algumas atividades importantes e custosas permaneceram não divididas, como a atividade de serviços de engenharia que representavam uma importante parte das operações do negócio, e vital para os clientes. Isso ocorreu devido aos recursos utilizados não possibilitarem identificar elementos que explicassem as diferenças entre os níveis da atividade.

Enunciam os autores: 
A classificação tem os seguintes requisitos:

1. Todos os produtos não demandam a mesma quantidade de uma única atividade;

2. Existem produtos que demandam quase a mesma quantidade de certa atividade. A quantidade de atividade dentro de certo nível deveria ter uma distribuição suficientemente pequena;

3. Existem grupos de produtos que não apenas demandam a mesma quantidade de certa atividade, bem como toda estrutura de atividade é semelhante;

4. Existem experts disponíveis que podem eliminar combinações de estruturas de atividades que não existem. (KULMALA, PARANKO e YRJÄNÄNEN, 2000, tradução nossa)

Novamente, a barreira tempo interpõe-se na transmissão dos custos dos recursos para as atividades. Outrossim, distinto obstáculo corrobora as dificuldades, o tamanho do lote.

\subsubsection{O lote}

Em outro trabalho, Yrjänäinen e Paranko (2001) desvelam a importância dos custos de lote nas atividades logísticas, focando pequenos pedidos para demonstrar seu ponto de vista. Argumentam os autores que empresas manufatureiras têm tipicamente calculado os custos dos produtos nos quais os custos de atividades são designados a unidades separadas. Estudar a rentabilidade do produto usando o cálculo feito para uma unidade tem sido praticável, devido ao grande número de atividades de nível unitário e lotes de produção padronizados.

Os lotes padronizados possibilitaram dividir os custos das atividades em nível de lote pelo número de unidades do lote, para calcular os custos das atividades consumidas pela unidade produzida.

No entanto a situação para empresas logísticas é bem diferente. Atividades de nível unitário praticamente não existem e a maioria dos custos advém das atividades relativas à aquisição e distribuição, as quais usualmente são atividades de nível de lote. Num ambiente logístico, uma atividade em nível de lote pode ser considerada uma atividade realizada num ato de compra ou de venda.

Tal ato pode incluir uma ou várias unidades e o tempo requerido para realizar a atividade é idêntico, não obstante o número de unidades envolvidas. Por exemplo, a entrada de um pedido leva o mesmo tempo; queira o consumidor uma ou cem unidades de certo produto de uma vez, o custo da atividade seria o mesmo. 
Diferentes clientes de empresas logísticas compram os mesmos produtos em lotes de entrega diferentes. Clientes pequenos compram poucas unidades, enquanto clientes de grande volume podem comprar centenas de unidades do mesmo produto de uma vez. Alguns até mesmo operam das duas maneiras. A complexidade em empresas logísticas aumenta mais ainda, pela grande variação nos preços de venda para diferentes clientes.

Para se designar o custo de uma atividade em nível de lote para um produto, deve-se dividir o custo da atividade pelo número de unidades do lote. Isso funciona para logística de entrada (aquisição) e saída (vendas). Desse modo, claramente, pode-se encontrar o estreito relacionamento entre o custo do produto e o tamanho do lote. Exemplificam os autores, Figura 46:

\begin{tabular}{|c|c|c|c|c|}
\hline \multirow{2}{*}{ Produto X } & \multicolumn{2}{|l|}{ Preço de compra: } & $\$ 13,00$ \\
\cline { 3 - 5 } & \multicolumn{2}{|l|}{ Custo logístico de entrada: } & $\$ 19,00$ \\
\cline { 3 - 5 } \multicolumn{2}{l|}{} & $\begin{array}{l}\text { Custo logístico de saída: } \\
\$ 78,00\end{array}$ \\
\hline $\begin{array}{c}\text { Tamanho do lote } \\
\text { de compra }\end{array}$ & $\begin{array}{l}\text { Tamanho do lote } \\
\text { de venda }\end{array}$ & $\begin{array}{l}\text { Custo logístico } \\
\text { de entrada }\end{array}$ & $\begin{array}{l}\text { Custo logístico } \\
\text { de saída }\end{array}$ & Custo total \\
\hline 10 & 1 & $\$ 1,90$ & $\$ 78,00$ & $\$ 92,90$ \\
\hline 10 & 2 & $\$ 1,90$ & $\$ 39,00$ & $\$ 53,90$ \\
\hline 10 & 5 & $\$ 1,90$ & $\$ 15,60$ & $\$ 30,50$ \\
\hline 10 & 10 & $\$ 1,90$ & $\$ 7,80$ & $\$ 22,70$ \\
\hline 10 & 20 & $\$ 1,90$ & $\$ 3,90$ & $\$ 18,80$ \\
\hline
\end{tabular}

Figura 46 : O impacto do tamanho do lote de venda nos custos a seres designados para uma unidade.

Fonte: Yrjänäinen e Paranko (2001)

Para se calcular o custo baseado em atividade de um produto, os custos das atividades de logística de entrada $(\$ 19,00)$ necessitam ser divididos pelo número de unidades do lote de compra (10) e os custos das atividades de logística de saída $(\$ 78,00)$ pelo número de unidades do lote de venda ( 1 a 20). O custo total de uma unidade é a soma dos custos das atividades consumidas, mais o preço de compra. A Figura 46 demonstra claramente a queda dos custos das atividades à medida que o tamanho do lote aumenta.

Os cálculos tradicionais do custo baseado em atividades do produto não funcionam porque lotes padronizados não existem. Atividades em nível de lote estão ainda causando a maioria dos custos. Uma nova concepção é necessária. (YRJÄNÄINEN e PARANKO ,2001, tradução nossa). 
Para contornar esse problema, os autores recomendam determinar os custos de cada ordem de venda do produto analisado e calcular também os lucros do produto em cada venda. Somando-se os lucros individuais de cada ordem de venda de um período particular de tempo, a verdadeira rentabilidade do produto pode ser determinada. Usando o lucro acumulado e as vendas líquidas do produto, uma margem de ganho de produto pode ser calculada. As possíveis razões de uma rentabilidade boa ou ruim podem ser analisadas estudando cada ordem separadamente, ilustram os autores, de acordo a Figura 47.

Na referida figura, os custos de logística de entrada $(\$ 19,00)$ foram divididos pelo tamanho padrão do lote de compra (50), obtendo-se como resultado o custo das atividades relativas à logística de entrada de cada unidade. $\mathrm{O}$ mesmo foi feito com os custos de logística de saída; dividiram-se tais custos $(\$ 78,00)$ pelo número de unidades vendidas, as quais variam de 1 a 50. Devido à grande variação do tamanho do lote de venda, os custos designados à unidade do produto $\mathrm{X}$ variaram de $\$ 1,56$ a $\$ 78,00$. $\mathrm{O}$ custo total de cada produto é obtido somando-se os custos das atividades de logística de entrada, saída, inventário $(\$ 0,07)$ e compras $(\$ 13,00)$. Subtraindo-se o valor da venda por esses custos, tem-se o lucro do produto e, multiplicando-se este valor pelo número de unidades do lote de venda, tem-se o lucro da ordem de venda. Somando-se tais lucros tem-se, na última linha da última coluna, o lucro acumulado do produto. Para chegar-se a margem de lucro do produto, basta dividir o lucro acumulado do produto $(\$ 5920,74)$ pelo valor das vendas líquidas (\$15909,97).

Contudo não se esclarece como o lucro acumulado do produto é formado. Para resolver esse problema Yrjänäinen e Paranko (2001) sugerem dividir os dados da Figura 47 para cada cliente, demonstrando o lucro acumulado do mesmo produto $\mathrm{X}$, e como demonstra a Figura 48.

Segundo esse critério, percebe-se, facilmente, quais clientes são lucrativos e quais não o são, encontrando-se informações sobre como agir diante do dilema lote / preço. Afirmam os autores:

A causa mais provável para perdas em ambientes logísticos serão aquelas ordens com preços comparados muito baixos com pequenos lotes de entrega. Lucros, por outro lado, podem ser explicados com grandes lotes favoráveis combinados com preços razoáveis. (YRJÄNÄINEN e PARANKO ,2001, tradução nossa). 


\begin{tabular}{|c|c|c|c|c|c|c|c|c|c|c|}
\hline \multicolumn{2}{|c|}{ Produto $\mathrm{X}$} & \multicolumn{3}{|c|}{$\begin{array}{l}\text { Tamanho do lote de compra } \\
50\end{array}$} & \multirow[b]{3}{*}{$\begin{array}{l}\text { Custo } \\
\text { de } \\
\text { saída } \\
(\$) \\
\end{array}$} & \multirow{2}{*}{\multicolumn{3}{|c|}{$\begin{array}{l}\text { Lucro acumulado } \\
\text { Venda / produto }\end{array}$}} & \multirow{2}{*}{\multicolumn{2}{|c|}{$\begin{array}{l}\$ 5920,74 \\
\$ 15909,97\end{array}$}} \\
\hline \multicolumn{5}{|c|}{ Margem de lucro do produto: $37,2 \%$} & & & & & & \\
\hline Cliente & $\begin{array}{l}\text { Preço } \\
\text { de } \\
\text { compra } \\
(\$) \\
\end{array}$ & $\begin{array}{l}\text { Preço } \\
\text { de } \\
\text { venda } \\
(\$)\end{array}$ & $\begin{array}{l}\text { Lote } \\
\text { de } \\
\text { venda } \\
(\$) \\
\end{array}$ & $\begin{array}{l}\text { Custo } \\
\text { de } \\
\text { entrada } \\
(\$) \\
\end{array}$ & & $\begin{array}{l}\text { Custo de } \\
\text { inventário } \\
(\$)\end{array}$ & $\begin{array}{l}\text { Lucro/un } \\
(\$)\end{array}$ & $\begin{array}{l}\text { Lucro/ordem } \\
(\$)\end{array}$ & $\begin{array}{l}\text { Margem de } \\
\text { lucro/ordem }\end{array}$ & $\begin{array}{l}\text { Lucro } \\
\text { acumu (\$) }\end{array}$ \\
\hline A & 13 & 25,4 & 50 & 0,38 & 1,56 & 0,07 & 10,39 & 519,37 & $41 \%$ & 519,37 \\
\hline A & 13 & 25,4 & 50 & 0,38 & 1,56 & 0,07 & 10,39 & 519,37 & $41 \%$ & 1038,74 \\
\hline $\mathrm{D}$ & 13 & 22,54 & 3 & 0,38 & 26 & 0,07 & $-16,91$ & $-50,74$ & $-75 \%$ & 988 \\
\hline $\mathrm{E}$ & 13 & 22,54 & 1 & 0,38 & 78 & 0,07 & $-68,91$ & $-68,91$ & $-306 \%$ & 919,09 \\
\hline A & 13 & 25,4 & 50 & 0,38 & 1,56 & 0,07 & 10,39 & 519,37 & $41 \%$ & 1438,46 \\
\hline B & 13 & 25,4 & 2 & 0,38 & 39 & 0,07 & $-27,05$ & $-54,11$ & $-106 \%$ & 1384,35 \\
\hline A & 13 & 25,4 & 50 & 0,38 & 1,56 & 0,07 & 10,39 & 519,37 & $41 \%$ & 1903,72 \\
\hline A & 13 & 25,4 & 50 & 0,38 & 1,56 & 0,07 & 10,39 & 519,37 & $41 \%$ & 2423,09 \\
\hline B & 13 & 25,4 & 2 & 0,38 & 39 & 0,07 & $-27,05$ & $-54,11$ & $-106 \%$ & 2368,98 \\
\hline A & 13 & 25,4 & 50 & 0,38 & 1,56 & 0,07 & 10,39 & 519,37 & $41 \%$ & 2888,35 \\
\hline $\mathrm{C}$ & 13 & 30,78 & 10 & 0,38 & 7,8 & 0,07 & 9,53 & 95,29 & $31 \%$ & 2983,64 \\
\hline $\mathrm{D}$ & 13 & 23,21 & 1 & 0,38 & 78 & 0,07 & $-68,24$ & $-68,24$ & $-306 \%$ & 2915,4 \\
\hline A & 13 & 25,4 & 50 & 0,38 & 1,56 & 0,07 & 10,39 & 519,37 & $41 \%$ & 3434,77 \\
\hline $\mathrm{C}$ & 13 & 31,62 & 20 & 0,38 & 3,9 & 0,07 & 14,27 & 285,41 & $45 \%$ & 3720,18 \\
\hline B & 13 & 25,4 & 2 & 0,38 & 39 & 0,07 & $-27,05$ & $-54,11$ & $-106 \%$ & 3666,07 \\
\hline A & 13 & 25,4 & 50 & 0,38 & 1,56 & 0,07 & 10,39 & 519,37 & $41 \%$ & 4185,44 \\
\hline B & 13 & 25,4 & 2 & 0,38 & 39 & 0,07 & $-27,05$ & $-54,11$ & $-106 \%$ & 4131,33 \\
\hline A & 13 & 25,4 & 50 & 0,38 & 1,56 & 0,07 & 10,39 & 519,37 & $41 \%$ & 4650,7 \\
\hline B & 13 & 25,4 & 2 & 0,38 & 39 & 0,07 & $-27,05$ & $-54,11$ & $-106 \%$ & 4596,59 \\
\hline A & 13 & 25,4 & 50 & 0,38 & 1,56 & 0,07 & 10,39 & 519,37 & $41 \%$ & 5115,96 \\
\hline $\mathrm{C}$ & 13 & 31,62 & 20 & 0,38 & 3,9 & 0,07 & 14,27 & 285,41 & $45 \%$ & 5401,37 \\
\hline A & 13 & 25,4 & 50 & 0,38 & 1,56 & 0,07 & 10,39 & 519,37 & $41 \%$ & 5920,74 \\
\hline
\end{tabular}

Figura 47: Lucro acumulado do produto $X$

Fonte: Yrjänäinen e Paranko (2001) 


\begin{tabular}{|c|c|c|c|c|c|c|c|c|c|c|}
\hline \multicolumn{2}{|c|}{ Produto X } & \multicolumn{3}{|c|}{$\begin{array}{l}\text { Tamanho do lote de compra } \\
: 50\end{array}$} & & \multicolumn{3}{|c|}{ Lucro acumulado } & \multicolumn{2}{|c|}{$\$ 5920,74$} \\
\hline Cliente & $\begin{array}{l}\text { Preço } \\
\text { de } \\
\text { compra } \\
(\$)\end{array}$ & $\begin{array}{l}\text { Preço de } \\
\text { venda } \\
(\$)\end{array}$ & $\begin{array}{l}\text { Lote } \\
\text { de } \\
\text { venda } \\
(\$)\end{array}$ & \begin{tabular}{|l|} 
Custo \\
de \\
entrada \\
$(\$)$
\end{tabular} & $\begin{array}{l}\text { Custo } \\
\text { de saída } \\
(\$)\end{array}$ & $\begin{array}{l}\text { Custo de } \\
\text { inventário } \\
(\$)\end{array}$ & $\begin{array}{l}\text { Lucro/un } \\
(\$)\end{array}$ & $\begin{array}{l}\text { Lucro/ordem } \\
(\$)\end{array}$ & $\begin{array}{l}\text { Margem de } \\
\text { lucro/ordem }\end{array}$ & $\begin{array}{l}\text { Lucro } \\
\text { acumu }(\$)\end{array}$ \\
\hline A & 13 & 25,4 & 50 & 0,38 & 1,56 & 0,07 & 10,39 & 519,37 & $41 \%$ & 519,37 \\
\hline A & 13 & 25,4 & 50 & 0,38 & 1,56 & 0,07 & 10,39 & 519,37 & $41 \%$ & 1038,74 \\
\hline A & 13 & 25,4 & 50 & 0,38 & 1,56 & 0,07 & 10,39 & 519,37 & $41 \%$ & 1558,11 \\
\hline A & 13 & 25,4 & 50 & 0,38 & 1,56 & 0,07 & 10,39 & 519,37 & $41 \%$ & 2077,48 \\
\hline A & 13 & 25,4 & 50 & 0,38 & 1,56 & 0,07 & 10,39 & 519,37 & $41 \%$ & 2596,85 \\
\hline A & 13 & 25,4 & 50 & 0,38 & 1,56 & 0,07 & 10,39 & 519,37 & $41 \%$ & 3116,22 \\
\hline A & 13 & 25,4 & 50 & 0,38 & 1,56 & 0,07 & 10,39 & 519,37 & $41 \%$ & 3635,59 \\
\hline A & 13 & 25,4 & 50 & 0,38 & 1,56 & 0,07 & 10,39 & 519,37 & $41 \%$ & 4154,96 \\
\hline A & 13 & 25,4 & 50 & 0,38 & 1,56 & 0,07 & 10,39 & 519,37 & $41 \%$ & 4674,33 \\
\hline A & 13 & 25,4 & 50 & 0,38 & 1,56 & 0,07 & 10,39 & 519,37 & $41 \%$ & 5193,7 \\
\hline A & 13 & 25,4 & 50 & 0,38 & 1,56 & 0,07 & 10,39 & 519,37 & $41 \%$ & 5713,07 \\
\hline \multicolumn{4}{|c|}{ Vendas/cliente } & \multicolumn{4}{|c|}{ Margem de lucro do consumidor } & \multicolumn{2}{|l|}{$40,9 \%$} & \\
\hline $\mathrm{B}$ & 13 & 25,4 & 2 & 0,38 & 39 & 0,07 & $-27,05$ & $-54,11$ & $-106 \%$ & $-54,11$ \\
\hline B & 13 & 25,4 & 2 & 0,38 & 39 & 0,07 & $-27,05$ & $-54,11$ & $-106 \%$ & $-108,22$ \\
\hline B & 13 & 25,4 & 2 & 0,38 & 39 & 0,07 & $-27,05$ & $-54,11$ & $-106 \%$ & $-162,33$ \\
\hline $\mathrm{B}$ & 13 & 25,4 & 2 & 0,38 & 39 & 0,07 & $-27,05$ & $-54,11$ & $-106 \%$ & $-216,44$ \\
\hline $\mathrm{B}$ & 13 & 25,4 & 2 & 0,38 & 39 & 0,07 & $-27,05$ & $-54,11$ & $-106 \%$ & $-270,55$ \\
\hline \multicolumn{4}{|c|}{ Vendas/cliente } & \multicolumn{4}{|c|}{ Margem de lucro do consumidor } & $-106,5 \%$ & & \\
\hline $\mathrm{C}$ & 13 & 30,78 & 10 & 0,38 & 7,8 & 0,07 & 9,53 & 95,29 & $31 \%$ & 95,29 \\
\hline $\mathrm{C}$ & 13 & 31,62 & 20 & 0,38 & 3,9 & 0,07 & 14,27 & 285,41 & $45 \%$ & 380,7 \\
\hline $\mathrm{C}$ & 13 & 31,62 & 20 & 0,38 & 3,9 & 0,07 & 14,27 & 285,41 & $45 \%$ & 666,11 \\
\hline \multicolumn{2}{|c|}{ Vendas/cliente } & $\$ 1572$ & & \multicolumn{4}{|c|}{ Margem de lucro do consumidor } & $42,4 \%$ & & \\
\hline
\end{tabular}




\begin{tabular}{|c|c|c|c|c|c|c|c|c|c|c|}
\hline \multicolumn{11}{|c|}{ Continuação } \\
\hline Cliente & $\begin{array}{l}\text { Preço } \\
\text { de } \\
\text { compra } \\
(\$)\end{array}$ & $\begin{array}{l}\text { Preço de } \\
\text { venda } \\
(\$)\end{array}$ & $\begin{array}{l}\text { Lote } \\
\text { de } \\
\text { venda } \\
(\$) \\
\end{array}$ & $\begin{array}{l}\text { Custo } \\
\text { de } \\
\text { entrada } \\
(\$)\end{array}$ & $\begin{array}{l}\text { Custo } \\
\text { de saída } \\
(\$)\end{array}$ & $\begin{array}{l}\text { Custo de } \\
\text { inventário } \\
(\$)\end{array}$ & $\begin{array}{l}\text { Lucro/un } \\
(\$)\end{array}$ & $\begin{array}{l}\text { Lucro/ordem } \\
(\$)\end{array}$ & $\begin{array}{l}\text { Margem de } \\
\text { lucro/ordem }\end{array}$ & $\begin{array}{l}\text { Lucro } \\
\text { acumu (\$) }\end{array}$ \\
\hline $\mathrm{D}$ & 13 & 22,54 & 3 & 0,38 & 26 & 0,07 & $-16,91$ & $-50,74$ & $-75 \%$ & $-50,74$ \\
\hline $\mathrm{D}$ & 13 & 23,21 & 1 & 0,38 & 78 & 0,07 & $-68,24$ & $-68,24$ & $-294 \%$ & $-118,97$ \\
\hline \multicolumn{4}{|c|}{ Vendas/cliente } & \multicolumn{4}{|c|}{ Margem de lucro do consumidor } & \multicolumn{3}{|l|}{$-131 \%$} \\
\hline $\mathrm{E}$ & 13 & 22,54 & 1 & 0,38 & 78 & 0,07 & $-68,91$ & $-68,91$ & $-306 \%$ & $-68,91$ \\
\hline \multicolumn{4}{|c|}{ Vendas/cliente } & \multicolumn{4}{|c|}{ Margem de lucro do consumidor } & $-305,8 \%$ & & \\
\hline
\end{tabular}

Figura 48: Lucro acumulado do produto $\mathrm{X}$ para cada cliente

Fonte: Yrjänäinen e Paranko (2001) 
Depois de apresentarem seus argumentos em relação à influência do tamanho dos lotes de venda no custo logístico baseado em atividades, os autores testaram o modelo em três produtos de uma companhia, calculado o lucro acumulado dos clientes em um semestre, e chegaram a resultados interessantes. No primeiro piloto, os clientes não lucrativos foram, principalmente, varejistas que ganharam descontos significativos mesmo comprando em pequenos lotes de entrega. No terceiro piloto o cliente menos lucrativo foi um grande construtor de máquinas com alto volume anual, comprando, porém, componentes apenas para um projeto em particular. Semanalmente, eram feitas de duas a três entregas do produto, com lotes entre uma e cinco unidades.

Concluem os autores:

Em empresas logísticas a lucratividade do produto não deveria ser calculada da mesma forma como o é tipicamente na indústria manufatureira. $\mathrm{O}$ tradicional custeio baseado em atividades dos produtos é distorcido por:

- grande porção de atividades em nível de lote,

- grande variação nos tamanhos dos lotes de entrega entre clientes,

- diferentes preços de venda para diferentes clientes, e

- variação no tamanho do lote de entrega e até mesmo nos preços de venda de um produto para o mesmo cliente. (YRJÄNÄINEN e PARANKO ,2001, tradução nossa).

Ressalvam generalizações, porém apontando para o método de lucratividade acumulada por cliente como ferramenta de expressivos ganhos.

\subsection{Considerações}

Depois de exposta a abordagem do método de custeio baseado em atividades escolhida neste trabalho, bem como outras direcionadas à logística, pode-se inferir que fatores como tempo e complexidade interferem na correta apuração dos custos logísticos de distribuição. Medidas como capacidade da atividade, dificuldade de execução da atividade e volume de saída da atividade perfazem parâmetros para contornar as dificuldades impostas pelos fatores citados quando se deseja custear objetos.

Retoma-se o principal problema do trabalho, que é descobrir quais são as particularidades da aplicação do método de custeio baseado em atividades na logística de distribuição numa empresa específica. Para solver este problema, faz-se necessário definir a metodologia desta pesquisa. Trabalho feito no capítulo vindouro. 


\section{CApítulo 5 - Metodologia de}

\section{PESQUISA}

\subsection{Introdução}

Segundo Demo (2001) pode-se sistematizar o trabalho científico sem prejuízo à criatividade, ordenando logicamente seus passos em: concepção do tema (lembrando que o tema mais bonito é o tema mais viável), hipótese (problema ou questão que se deseja perscrutar), fundamentação teórica (estudo reconstrutivo sistemático na busca de fundamentação na literatura disponível e concepção de argumentação própria), coleta e produção de dados (ressaltando que, dependendo do tema, a formalização destes deve permitir abertura crítica para quem duvide), a realização da hipótese (visa argumentar com a precisão propicia se o problema tomado no início foi solucionado e se o tema foi suficientemente tratado, o que conseguiu mostrar e o que ficou ainda não solucionado, bem como outra pista, se for o caso, que poderiam, em esforço futuro, ter melhor sucesso) e por fim a conclusão.

Este capítulo destina-se a esclarecer a metodologia do estudo empreendido, abordando o referencial teórico do trabalho, os objetivos, delineamento e instrumentos de coleta. As seções seguintes abordarão alguns pontos acerca da metodologia, para se definir o trabalho apresentado e possibilitar sua sistematização.

\subsection{Referencial teórico}

A controladoria, assim como a logística, apresenta características peculiares que devem ser levadas em conta pelo pesquisador na consideração de questões 
determinantes na escolha da estratégia de condução de um projeto de pesquisa. Os métodos de custeio permitem realizar uma análise quantitativa do assunto e a logística possui, em seus processos, um caráter mensurável. Devido a isso, o estudo neste campo permite que a realidade seja construída por fatos que possam ser observados e medidos, através de instrumentos como questionários, escalas de atitudes, escalas de opinião e manipulação estatística de dados.

Nesta linha, o presente trabalho possui um referencial teórico positivista. O adjetivo positivo pode ser compreendido de diversas maneiras: como real, evidente, não admitindo dúvidas, como aquilo que se manifesta na experiência, ao contrário do que provém de teorias ou fabulações, neste último sentido, o positivo dos fatos opõe-se ao negativo, do que não se apresenta como fenômeno.

Comte (1978) enumera cinco conceitos para a palavra positivo. A primeira designa o real em oposição ao quimérico. Assim, o espírito humano deve investigar o que é possível conhecer, eliminando a busca das causas últimas ou primeiras das coisas. O positivo é um estado sobre o útil ao invés do ocioso. A filosofia positiva deve guiar o ser humano para a certeza, distanciando-o da indecisão, deve elevá-lo ao preciso, eliminando o vago.

\subsection{0 método}

Para Lakatos e Marconi (1993, p.8):

Método é o conjunto das atividades sistemáticas e racionais que, com maior segurança e economia, permite alcançar o objetivo conhecimento válido e verdadeiro - traçando o caminho a ser seguido, detectando erros e auxiliando as decisões do cientista.

O método da pesquisa ou delineamento será o estudo de caso. Segundo Yin (2001) um estudo de caso é uma investigação empírica de um fenômeno contemporâneo dentro de seu contexto da vida real, especialmente quando os limites entre o fenômeno e o contexto não estão claramente definidos, bem como quando o número de variáveis de interesse é maior que o de pontos dados. $\mathrm{O}$ autor ressalta que a metodologia de estudo de caso é preferível quando o pesquisador tem pouco controle sobre os eventos e 
quando o foco se encontra em fenômenos contemporâneos inseridos em algum contexto da vida real, como é o caso do presente estudo. Ainda declara que o estudo de caso pode ser usado como estratégia exploratória, descritiva ou explanatória. E as estratégias de pesquisa não são mutuamente exclusivas (por exemplo, um levantamento em um estudo de caso ou um estudo de caso em um levantamento).

Quanto aos fins, esta pesquisa enquadra-se num estudo exploratório descritivo. Dane (1990) define uma pesquisa descritiva como aquela que tenta determinar se um fenômeno existe ou não, seja pela explicação do fenômeno em si ou pela sua correlação com algo. Uma pesquisa exploratória é aquela que examina um fenômeno para defini-lo de modo mais completo ou diferenciá-lo de outro fenômeno e ressalta que os resultados desse tipo de pesquisa podem mudar ao longo do tempo e que isso pode ser um fato interessante de se usar.

De acordo com Yin (2001) para um projeto de estudo de caso deve-se levar em conta cinco componentes:

- $\quad$ as questões de estudo de caso, que devem ser precisas e claras em relação à natureza do estudo;

- $\quad$ as proposições, que direcionam o pesquisador a evidências relevantes e fornecem fundamentação lógica ao estudo;

- $\quad$ unidade de análise, pois quanto mais proposições específicas o estudo tiver, mais exeqüível ele será;

- união dos dados às proposições, cuja melhor forma seria pela adequação ao padrão, onde várias partes da mesma informação, do mesmo caso, são relacionados à mesma proposição teórica;

- critérios para se interpretar as descobertas que, embora não exista uma maneira precisa de fazê-lo, leve a reconhecer padrões concorrentes e a demonstrar, claramente, de qual padrão a descoberta se aproxima.

A seguir, são abordados cada um dos cinco componentes. 


\subsection{Questões do estudo}

Para Dane (1990), as últimas metas de uma pesquisa são formular questões e achar respostas para estas questões. Para tanto, as questões devem permitir que os objetivos da pesquisas sejam alcançados. Nesse sentido, a questão do presente estudo é

Como custear as atividades de logística de distribuição pelo método de custeio baseado em atividades?

\subsection{Proposição ou hipótese}

Segundo Vergara (2000, p.38), hipóteses "são a antecipação da resposta ao problema". Os exames são realizados no intuito de confirmar ou refutar as suposições, estas feitas como uma afirmação inicial que se pretende analisar.

Neste estudo, a hipótese está relacionada à chamada pesquisa qualitativa, o que não implica a exclusão de análises quantitativas. Sendo assim a hipótese deste estudo é:

Peculiaridades inerentes às atividades logísticas de distribuição, como variações no tempo de execução e complexidade, exigem distinta abordagem na implantação do custeio baseado em atividades, de modo a cercear incorreções de custos.

De acordo com Gil (1994) a hipótese sugere explicações para os fatos conduzindo à verificação empírica. Existem diferentes tipos de hipótese:

- casuísticas - referem-se a algo que ocorre em determinado caso, afirmam que um objeto, ou pessoa, ou fato específico, tem determinada característica. Freqüentes na pesquisa histórica;

- referentes à freqüência de acontecimentos - antecipam que determinada característica ocorra, com maior ou menor intensidade, num grupo, sociedade ou cultura. 
- que estabelecem relações entre variáveis :

- relação causal : procura-se descobrir condições necessárias e suficientes para a ocorrência de determinado fenômeno,

- relação simétrica : nenhuma das variáveis influencia a outra,

- relação assimétrica : uma das variáveis influencia a outra,

- relação recíproca : as variáveis se influenciam mutuamente.

Esta pesquisa possui uma hipótese causal, de acordo com o acima exposto, pois procura descobrir condições necessárias e suficientes para a ocorrência de erros de custos. Tem como intuito demonstrar a influência do ambiente logístico na aplicação do custeio baseado em atividades.

\subsection{Variáveis}

Quanto às variáveis, Eisenhardt (1989) comenta que os investigadores devem formular um problema de pesquisa especificando possíveis variáveis de peso, com certa referência à literatura existente. Entretanto, deve-se evitar pensar em relações específicas entre variáveis e teorias tanto quanto possível, especialmente no início do processo. Para melhor definir o problema e elucidar a hipótese deste estudo, definem-se as variáveis da pesquisa como os custos logísticos de distribuição.

Esta variável macro será dividida em três categorias: custos de embalagem, custos de armazenagem e custos de manuseio e movimentação

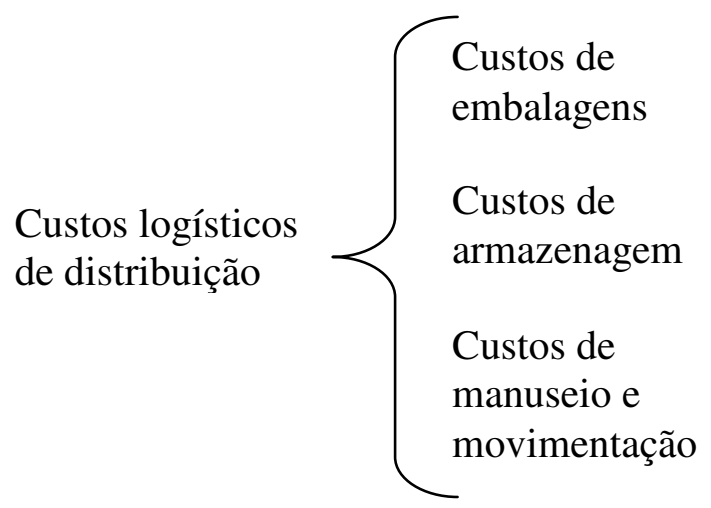

Para se identificar estes custos, serão utilizados relatórios contábeis-gerenciais, relatórios de despesas operacionais, inventários sobre ativos da logística, etc. 


\subsection{Unidade de análise}

Este item destina-se a evidenciar qual será a unidade de análise utilizada para realização do estudo de caso. Primeiramente, apresenta uma breve revisão sobre esse tema e ao fim indica qual será a unidade de análise.

De acordo com Yin (2001), existem quatro tipos de projetos de estudo de caso: único holístico, único incorporado, múltiplo holístico e múltiplo incorporado, que variam de acordo com o número de unidades de análise e com o modo que são reunidos os resultados.

Um projeto de caso único é adequado quando representa um caso decisivo ao testar uma teoria bem formulada, ou quando represente um caso raro ou extremo, ou, ainda, quando seja revelador à medida que o pesquisador tenha oportunidade de observar e analisar um fenômeno previamente inacessível à investigação científica. Porém antes de se decidir ao caso único, deve-se levar em conta sua vulnerabilidade em potencial.

Num estudo de caso único, pode-se analisar várias subunidades, o que resultaria num estudo caso incorporado. Caso se analise a natureza global de um objeto (programa, organização,...) tem-se um estudo de caso holístico. Cada um tem seu ônus e seu bônus, o holístico pode privar o pesquisador de examinar um fenômeno específico devido à sua abordagem geral, e o pesquisador pode não perceber a mudança da natureza do estudo durante a investigação. Porém o estudo de caso holístico é vantajoso quando não se pode identificar uma unidade lógica ou quando a teoria subjacente ao estudo é holística. No estudo de caso incorporado, pode haver problemas devido ao seu foco nas unidades e por não prover uma análise delas com o todo.

Quando um mesmo estudo abraça mais de um caso único, tem-se um projeto de casos múltiplos. A decisão por um estudo de caso múltiplo é difícil, pois demanda mais tempo e recursos. Mas, por outro lado, seus resultados são mais convincentes. Contudo o mais importante a se considerar é a lógica da replicação, e não da amostragem, quando se decidir ao estudo de caso múltiplo. Cada caso deve ser cuidadosamente selecionado de forma a prever resultados semelhantes ou produzir resultados contrastantes, por razões previsíveis. 
Para melhor fundamentar os procedimentos de replicação, torna-se importante desenvolver uma rica estrutura teórica, de ordem acadêmica ou prática que, futuramente, pode se tornar instrumento para generalizar novos casos, bem como escolher um número de casos suficientes para se atingir um bom grau de certeza. Neste ponto, deve-se preocupar com a validade externa do estudo.

Estudos de casos múltiplos podem ser holísticos ou incorporados, a diferença reside no tipo de fenômeno estudado. No incorporado, os resultados de cada levantamento não são reunidos para cada caso, ao contrário do holístico.

A partir das definições do autor acima citado, este estudo é classificado como um estudo de caso único, pois será analisado o centro de distribuição de uma empresa do setor de transformados plásticos, situada no interior do estado de São Paulo, e holístico, já que os custos logísticos de distribuição serão analisados de uma forma geral e os resultados serão reunidos conjuntamente.

\subsection{Instrumentos de coleta}

Yin (2001, p.107) comenta que a coleta de dados pode basear-se em muitas fontes de evidências. Nesta pesquisa, serão utilizadas as seguintes:

- $\quad$ documentação - por meio de relatórios contábeis-gerenciais das atividades de Logística;

- $\quad$ entrevista - foi utilizado um roteiro de perguntas, anexo I, no intuito de se conhecer a estrutura da unidade de análise, as atividades que a compõem, seus clientes e o fluxo de custos das contas da unidade;

- observação direta - através de visitas realizadas na unidade de análise, modelando os processos a partir de informações relevantes.

\subsection{Análise dos dados}

Yin (2001, p.131) define a análise de dados como: "exame, categorização, tabulação ou qualquer outra combinação das evidências, para se abordar as proposições iniciais de um estudo". Aponta a dificuldade de sua realização por não se dispor de 
muitas fórmulas pré-estabelecidas, levando o pesquisador a depender, sobremaneira, de seu próprio estilo e rigor na interpretação dos dados que tem em mãos.

Para Eisenhardt (1989), os pesquisadores, para gerar um construto teórico, combinam múltiplos métodos de coleta de dados. A triangulação torna possíveis fortes comparações entre construto e hipótese. Torna-se de grande importância combinar evidências qualitativas e quantitativas, além de utilizar-se de múltiplos investigadores, pois isso aumenta o potencial criativo do estudo e a certeza das descobertas.

Neste trabalho, a análise dos dados será feita pela triangulação daqueles, obtidos através de diferentes instrumentos de coleta: análise de documentos, entrevista e observação direta. Para tratar as evidências, se utilizarão os métodos de adequação ao padrão, análise de séries temporais e realização de um construto explicativo.

Munido de aparato metodológico, finalmente, será apresentado o estudo de caso realizado no intuito de atender o objetivo proposto. 


\section{CAPÍTULO 6 - ESTUDO DE CASO}

\subsection{O ambiente e a unidade}

Como dito anteriormente, a unidade de análise é o centro de distribuição de uma unidade de uma multinacional brasileira que integra o segmento de transformados plásticos. Para melhor caracterizar a empresa, será feita uma breve descrição do segmento no qual atua; em seguida, será descrita a empresa como um todo; depois a unidade fabril e, por fim, o centro de distribuição, incluso naquela. Essa descrição hierárquica visa especificar o universo e a unidade de análise encerrada, pois como argumenta Dane (1990):

"Uma pesquisa não deveria ocorrer num vazio, e sim num contexto de informações existentes sobre o assunto da pesquisa."

Gil (1994) complementa:

"O estudo de caso caracteriza-se por um profundo e exaustivo estudo de um ou de poucos objetos de modo empírico, quando não se distingue claramente a fronteira entre o contexto e o objeto de estudo e se utiliza várias fontes de evidência."

Finalmente, de acordo com Yin (2001):

"Para melhor fundamentar os procedimentos de replicação torna-se importante desenvolver uma rica estrutura teórica, de ordem acadêmica ou prática, que futuramente pode-se tornar instrumento para generalizar novos casos."

\subsubsection{O segmento de transformados plásticos}


O segmento dos transformados plásticos constitui a terceira geração da cadeia produtiva da indústria petroquímica. Esta pode ser dividida em três gerações, de acordo com as três etapas básicas de seus processos de produção, como demonstra a Figura 49.

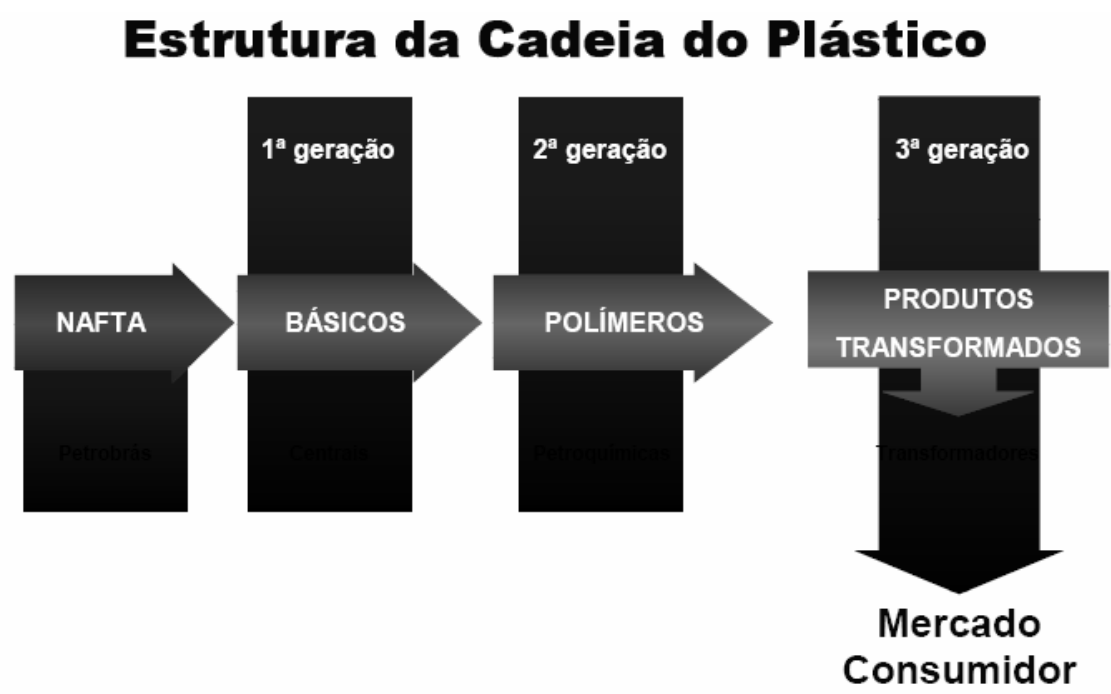

Figura 49 : Cadeia do plástico

Em primeiro lugar, destaca-se a chamada indústria de primeira geração, fornecedora das principais matérias-primas básicas para toda a cadeia e para o segmento de transformados plásticos (especificamente o eteno e o propeno). As empresas de primeira geração, usualmente chamadas de centrais de matéria-prima, utilizam a nafta, proveniente do processo de refino do petróleo, ou o gás natural, ou ainda o gás de refinaria e, por meio de um processo de craqueamento, os transformam nos insumos utilizados nas etapas subseqüentes da cadeia produtiva petroquímica. Através de uma reação química chamada polimerização, um grande número de moléculas individuais é reunido para formar cadeias de polímeros. Há duas famílias principais de polímeros: termoplásticos e termofixos.

O destino da produção das centrais de matéria-prima é a chamada indústria de segunda geração. O conjunto das indústrias de segunda geração se concentra ao redor das centrais de matéria-prima, formando os pólos petroquímicos integrados. Seu processo produtivo é caracterizado pela transformação das diversas matérias-primas em uma variada gama de intermediários, largamente utilizados por todo o conjunto da indústria química, entre estes, os chamados termoplásticos básicos, como o polietileno de baixa ou alta densidade (PEBD/PEAD), o polipropileno (PP), o policloreto de vinila (PVC), o poliestireno (PS), o polietileno tereftalato (PET), entre outros. 
O destino desses intermediários é a chamada indústria de terceira geração, na qual são transformados em produtos plásticos diversos, por meio de processos de injeção, sopros, filme, extrusão, entre outros. Estes produtos destinam-se tanto ao consumo intermediário (embalagens, autopeças, etc.), quanto ao consumo final (brinquedos, utilidades domésticas, etc.). O conjunto de empresas que compõem a chamada terceira geração não pertence ao gênero indústria petroquímica e, sim, a outros setores industriais, com destaque para o setor de transformação plástica. É precisamente neste segmento que se encontra a empresa utilizada no presente estudo

Entre as empresas que atuam nesse segmento da indústria, verifica-se uma grande heterogeneidade, manifestada de diversas formas. Podem ser encontradas empresas dos mais variados portes, desde microempresas atuando em nichos de mercado específicos, até empresas de grande porte ligadas a outras cadeias produtivas importantes, como a automotiva e a de eletrodomésticos. Desta forma, tais empresas atendem mercados bastante distintos, entre os quais destacam-se os segmentos de embalagens, laminados, calçados, brinquedos, construção civil, descartáveis, utilidades domésticas, agrícolas, componentes técnicos e outros. Ilustra-se, através da Figura 50, a segmentação do mercado de plástico por setor no Brasil para o ano de 2004.

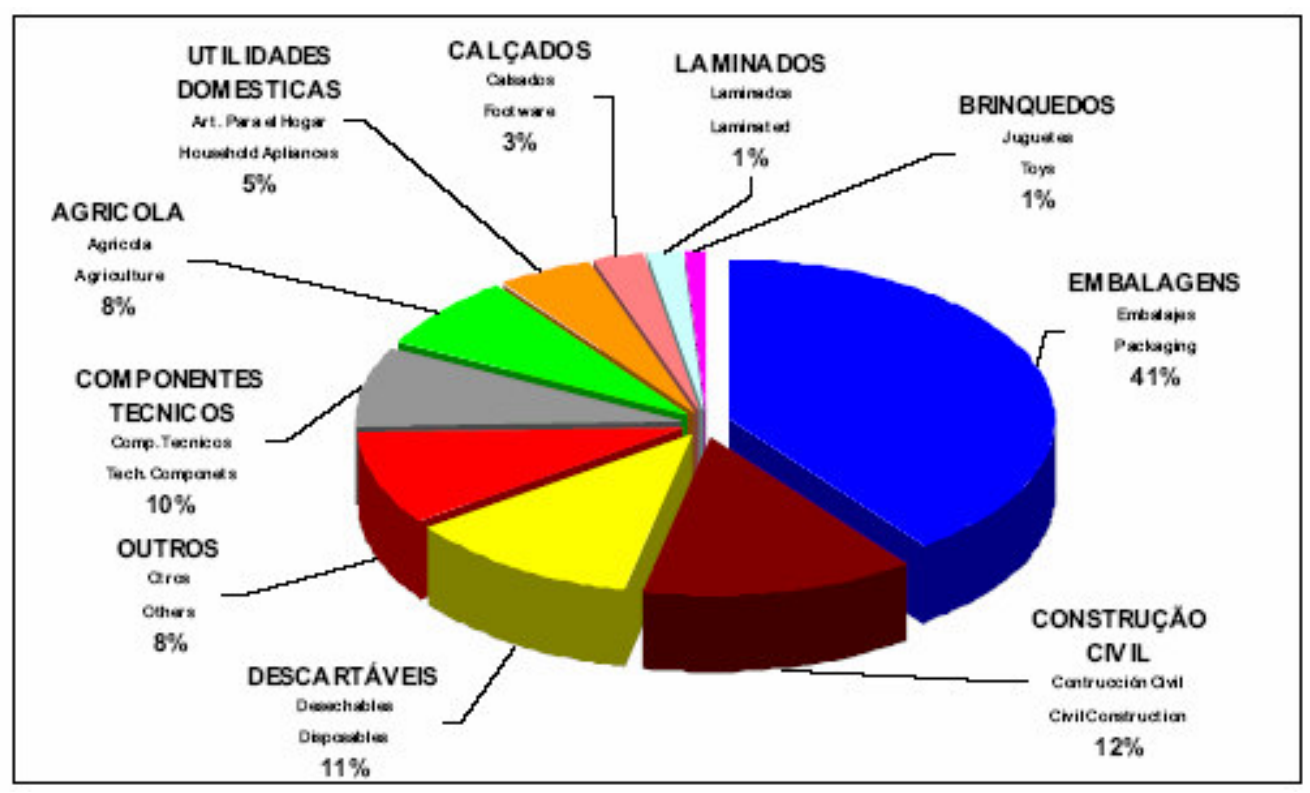

Figura 50 : Mercado de plástico brasileiro

Fonte: Associação Brasileira da Indústria de Plástico - ABIPLAST (2005)

No caso do segmento de tubos e conexões e demais materiais para a construção civil, é clara a liderança de um pequeno número de grandes empresas com 
marcas e com evidentes vantagens competitivas, tanto no que se refere às condições de atendimento à demanda segundo as novas técnicas, quanto às condições de logística e distribuição nas cadeias de distribuição.

Apesar de ser utilizado na produção de uma infinidade de produtos finais e de componentes e insumo para os mais variados setores industriais, o principal uso do PVC é a construção civil que gera a demanda por tubos, conexões e perfis. E o perfil de consumo, segundo a ABIPLAST (2005), é o seguinte: tubos 44\%; conexões 3,8\%; sopro (embalagens) 5,4\%; perfis 5,2\%; fios e cabos 5,8\%; calçados 9,0\%:filmes e chapas 20,0\%; usos diversos $6,8 \%$.

O segmento de transformação de plásticos no Brasil é constituído, segundo dados da ABIPLAST (2005), para 2003, por 8.213 estabelecimentos que empregavam formalmente em 2004236.626 trabalhadores. No período de 2000 a 2004, o consumo aparente de artefatos plásticos no Brasil apresentou variação positiva de 6,9\%, como demonstra a Figura 51, abaixo.

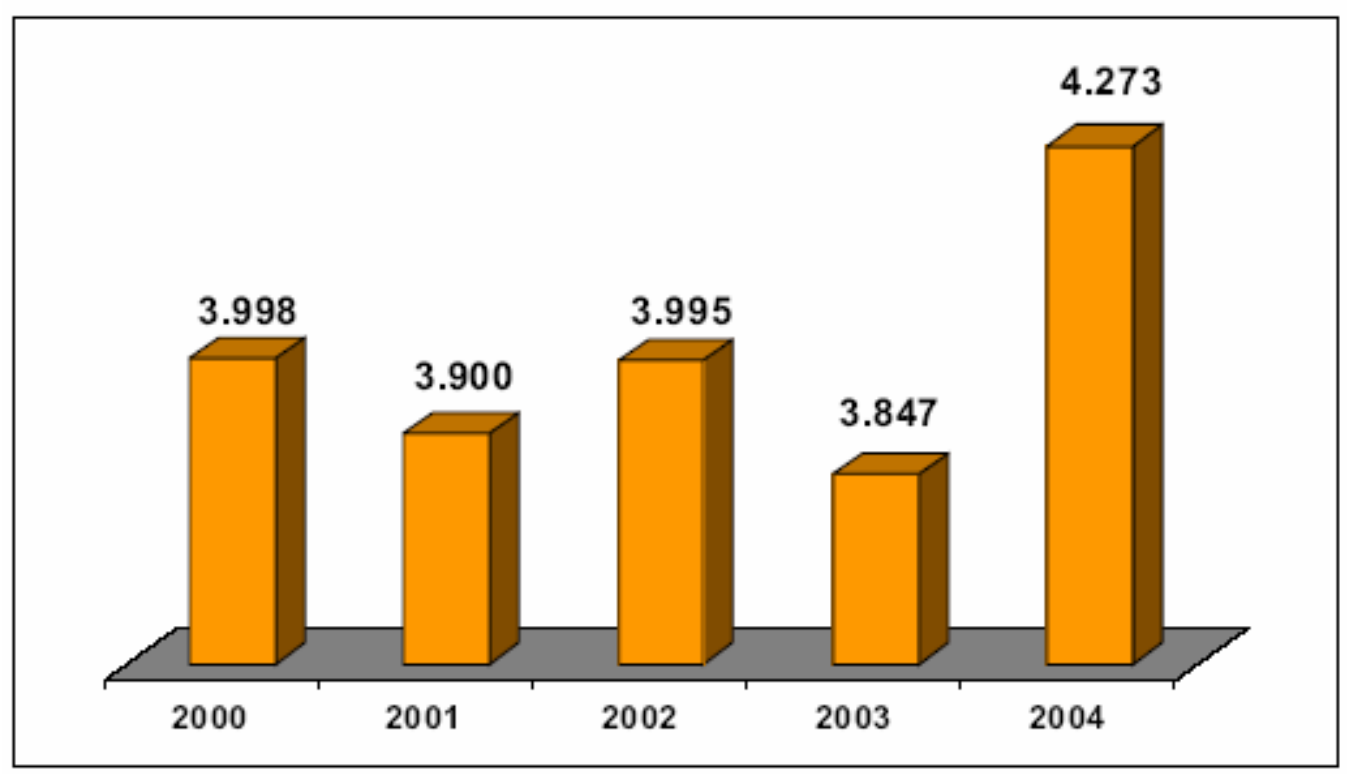

Figura 51 : Consumo aparente de artefatos transformados plásticos 2000 - 2004 - em 1.000 ton

Fonte: ABIPLAST (2205)

O faturamento da indústria de plástico entre 2000 e 2004 apresentou forte aumento entre os anos de 2001 e 2004, variando em média $49 \%$ a cada ano e crescendo à razão média de R \$ 9.319,8 milhões ao ano, como demonstra a Figura 52, abaixo. 

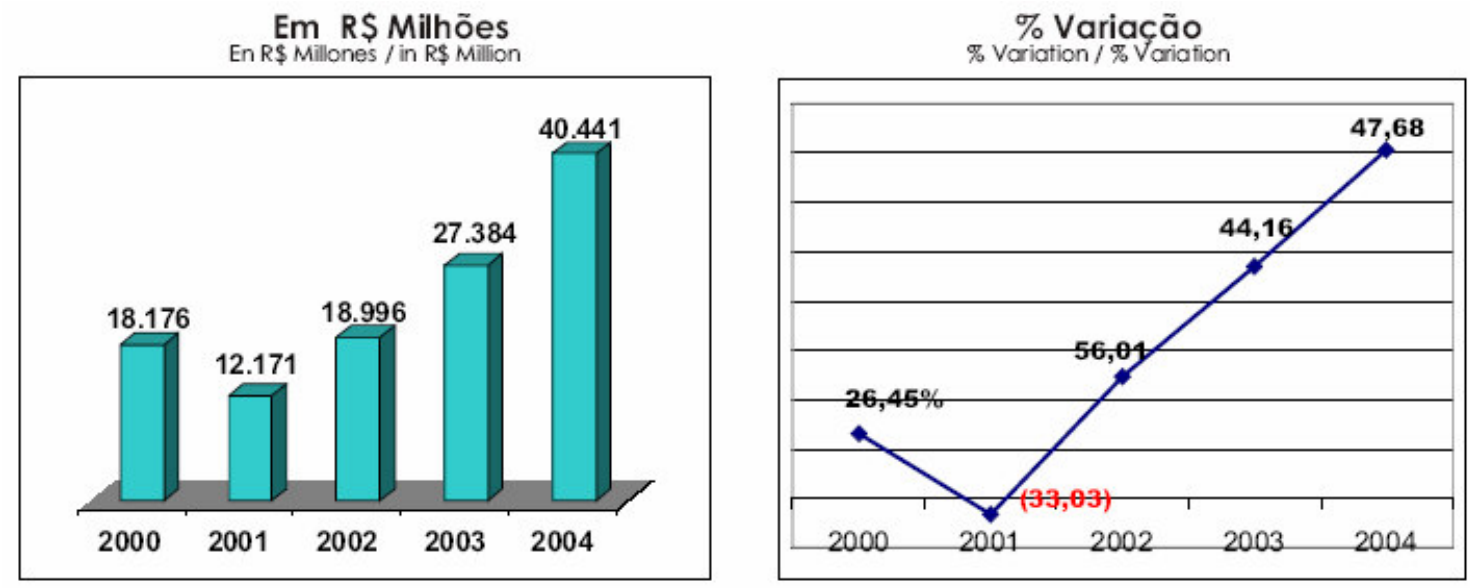

Figura 52 : Faturamento da indústria de plástico entre 2000 e 2004 em milhões Fonte: ABIPLAST (2005)

De modo geral, as exportações vêm crescendo desde 2002, como demonstram as Figuras 53 e 54.
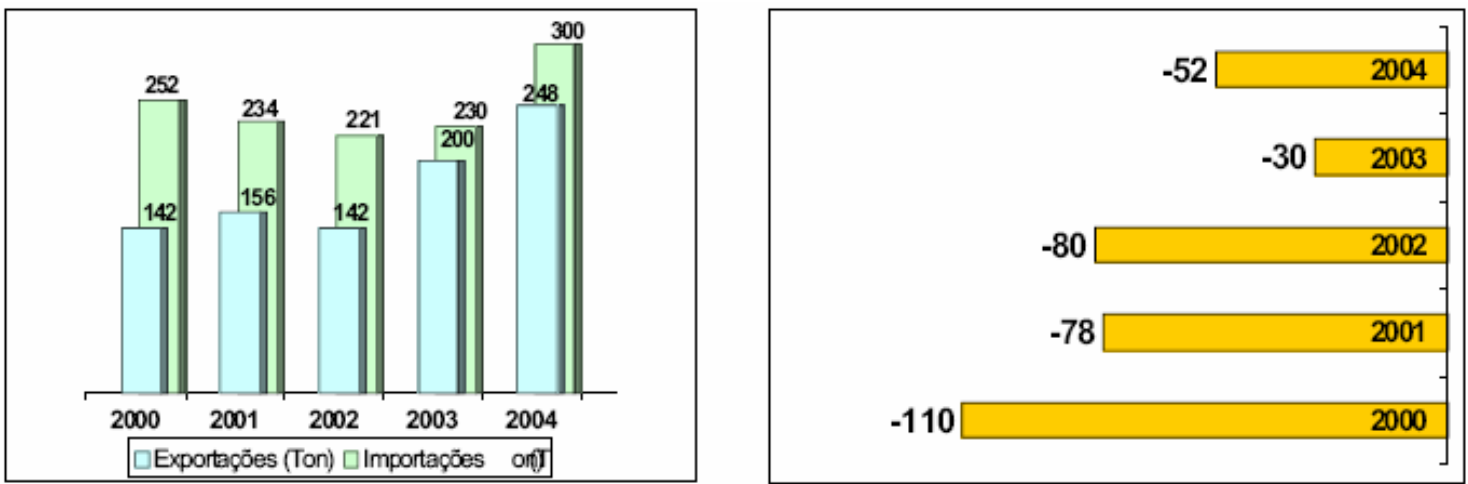

Figura 53 : Exportações e Importações de artefatos plásticos entre 2000 e 2004 em 1000 toneladas

Fonte: ABIPLAST (2005)
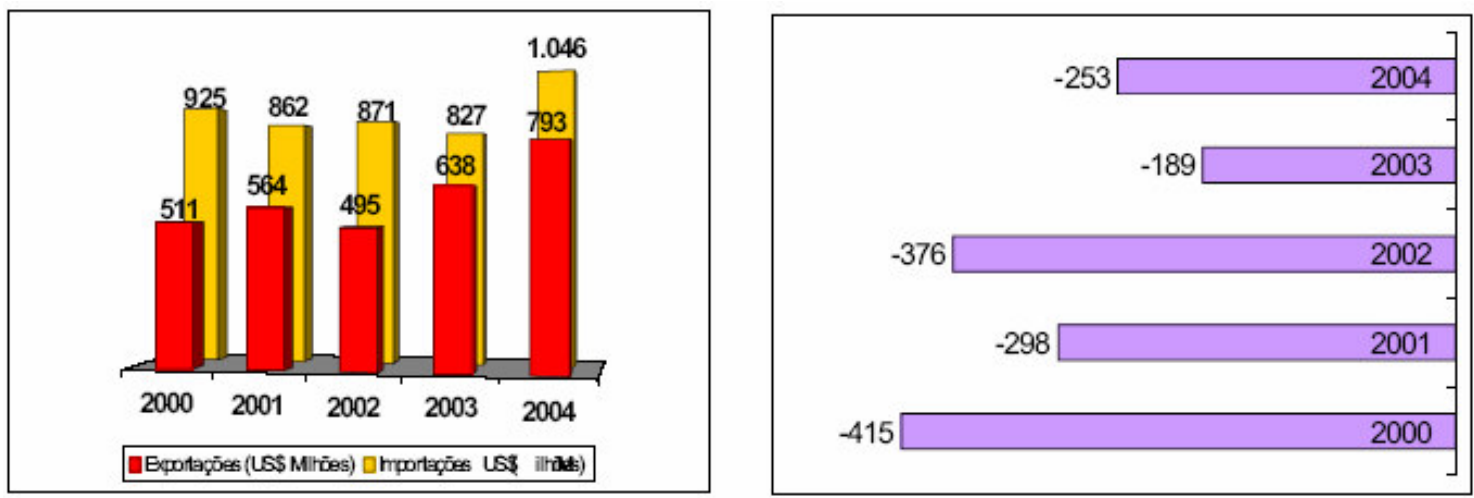

Figura 54 : Exportações e Importações de artefatos plásticos entre 2000 e 2004 em US\$ milhões

Fonte: ABIPLAST (2005) 
A participação do setor plástico no PIB Nacional atingiu sua cifra mais alta em 2004, de 2,26\%, aumentando em média 0,18 pontos percentuais desde 2000 como demonstra a Figura 55.

\begin{tabular}{|c|c|c|c|c|}
\hline \multicolumn{5}{|c|}{ Participação do Setor Plástico no PIB Nacional (\%) } \\
\hline & oementp & Procaseir & of GOP & \\
\hline 2000 & 2001 & 2002 & 2003 & 2004 \\
\hline 1,66 & 1,31 & 1,76 & 1,90 & 2,26 \\
\hline
\end{tabular}

Figura 55 : Participação do setor plástico no PIB nacional Fonte: ABIPLAST (2005)

Em 2005, segundo a Associação Brasileira da Indústria do Plástico, para o primeiro semestre, a indústria de transformação do plástico obteve alta de 32,8\% no faturamento, fechando em US\$ 7,9 bilhões, em relação ao mesmo período do ano anterior. Em reais, entretanto, o crescimento apresentado foi de apenas 8,78\%, o equivalente a $\mathrm{R} \$ 19,1$ bilhões - uma diferença percentual que se dá por conta da valorização da moeda nacional frente ao dólar.

Nesse mesmo período, as exportações registraram um crescimento de 27,3\% em valor, passando de US\$ 370 milhões em 2004, para US\$ 471 milhões em 2005, e de $14,8 \%$ em peso, saindo de 117,8 mil toneladas no ano passado e chegando a 135,3 mil toneladas este ano. As importações também apontaram um crescimento de 22,9\% em valor, passando de US\$ 485 milhões em 2004 para US\$ 597 milhões em 2005, e de $12,7 \%$ em peso, saindo de 135,4 mil toneladas no ano passado e chegando a 152,6 mil toneladas este ano.

Os números divulgados pela entidade mostram que, no $1^{\circ}$ semestre de 2005 , foram consumidas 2,1 milhões de toneladas de transformados plásticos, o que representa um aumento de 2,41\% com relação ao consumo do mesmo período de 2004.

Os investimentos estimados para o período 2000/2008 são de US\$ 17,7 bilhões para a ampliação da capacidade produtiva de resinas termoplásticas, de máquinas e de transformação de plásticos em bens de consumo finais e intermediários. Ainda que alguns analistas considerem que, no longo prazo, o Brasil não tem vantagens reais para justificar esses investimentos pesados, em função da baixa disponibilidade de gás natural próximo aos centros produtores e da dependência da importação de nafta.

Após esta descrição do panorama geral do setor, realizado para caracterizar a realidade em que a empresa se encontra, esta será objeto de investigação. Será descrita por um breve histórico e dissecada em números. 


\subsubsection{A empresa}

A origem da empresa remonta a 1941. Após o término da II Guerra e com a introdução do plástico no Brasil, a empresa começou a utilizar o novo material. Em 1945, seu fundador comprou a primeira máquina injetora de plástico e criou o setor de ferramentaria para a execução de moldes, tudo em plástico rígido. Essa linha de produtos foi muito importante para a fase de capitalização inicial da empresa.

Primeiramente, foram produzidas mangueiras para jardins, depois para a distribuição de gás e para transfusões de sangue. Em 1956, foram feitos os primeiros experimentos na extrusão dos tubos de PVC, o que coincidiu com o início do governo de Juscelino Kubitschek, cujo espírito desenvolvimentista levou a indústria nacional a saltos de crescimento. Em 1958, por 160 mil marcos, a empresa adquiriu uma máquina eifenäuser-90 para extrusão de tubos, uma Battenfeld-300 para injetar peças de PVC e uma trançadeira para produzir tubos flexíveis. No mesmo ano, a empresa lançou, pela primeira vez no Brasil, os tubos rosqueáveis de PVC, nos mesmos diâmetros dos canos de ferro que dominavam o mercado.

No início de 1977, a empresa dá o primeiro passo além das fronteiras do Brasil, instalando no Paraguai, uma empresa que atualmente atende $90 \%$ da demanda local. Em abril de 2005 inaugura uma fábrica no Chile, em espaço de 17 mil metros quadrados nos arredores de Santiago. A unidade na Argentina está sendo ampliada e o parque fabril em Santa Cruz de la Sierra, na Bolívia, foi renovado. O mercado dos Emirados Árabes Unidos é atraente: lá, abriu filial em Dubai. O presidente anunciou investimentos de R \$ 50 milhões para 2005, na modernização de todas as unidades e na fabricação de linhas para o mercado norte-americano. Além disso, há interesse em entrar no México e Colômbia.

Atualmente, a empresa processa aproximadamente 1,84 bilhões de ton/ano, com uma força de trabalho de 2592 funcionários, faturando, no ano de 2004, em torno de R $\$ 1,7$ bilhões, sendo uma das 5 maiores empresas do mundo no setor. Situa-se em Rio Claro, a mais moderna fábrica do planeta. A Figura 56 demonstra, em linhas gerais, o organograma da empresa. Para distribuir a produção, a empresa conta com cinco centros de distribuição em Joinville, Rio Claro, Camaçari, Indaiatuba e Belém.

$\mathrm{Na}$ Tabela 7, encontram-se alguns dados históricos recentes da empresa. Para bem interpretá-los algumas explicações, em relação aos dados, encontram-se abaixo da referida tabela. 


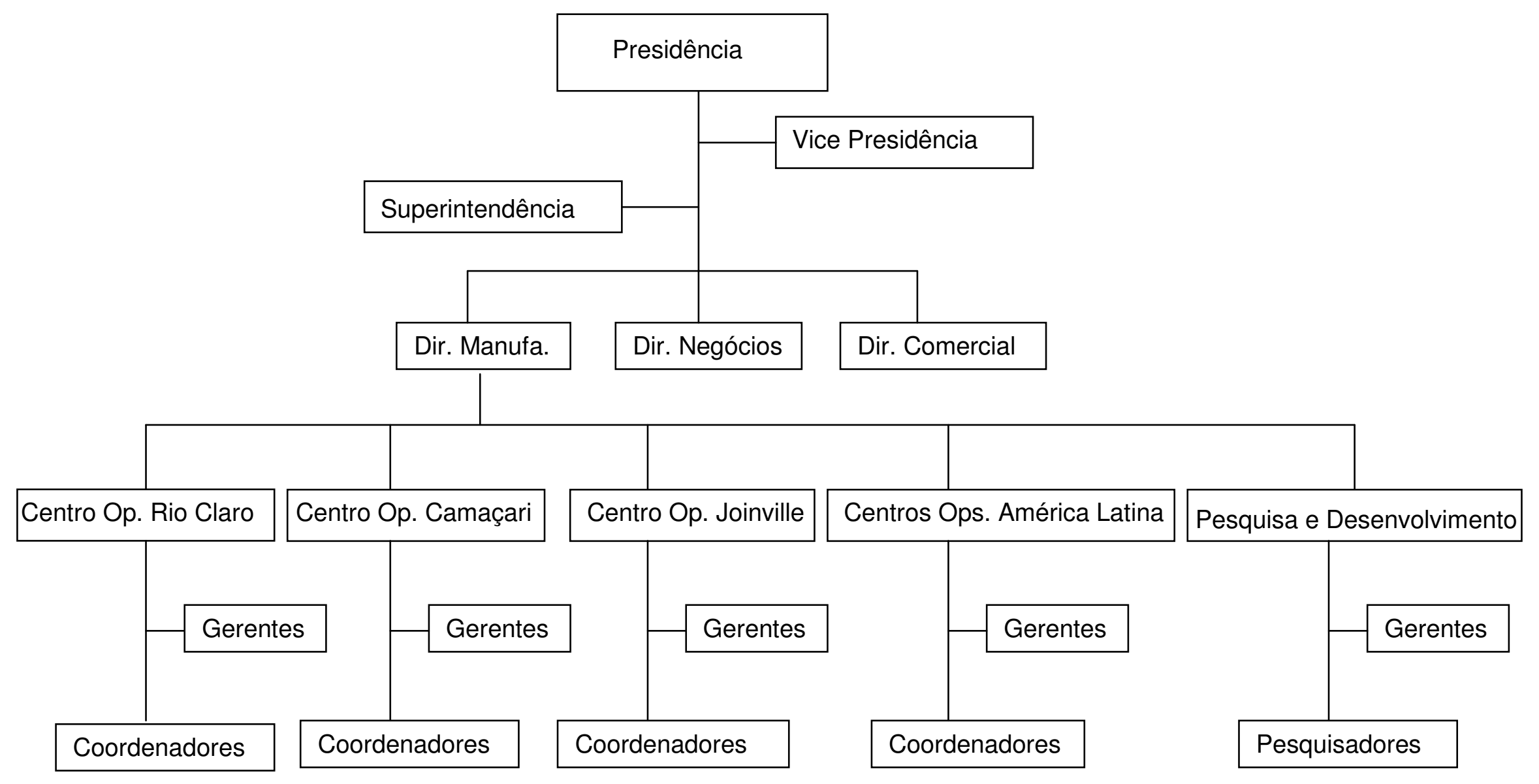

Figura 56 : Organograma da empresa 
Tabela 7 : Dados históricos sobre a empresa pesquisada

\begin{tabular}{|c|c|c|c|c|c|c|c|c|c|c|c|c|c|c|c|}
\hline \multirow[b]{2}{*}{ 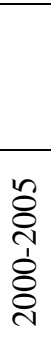 } & \multicolumn{2}{|c|}{ Vendas } & \multicolumn{2}{|c|}{ Patrimônio } & \multicolumn{2}{|c|}{ Lucro } & \multicolumn{2}{|c|}{$\begin{array}{l}\text { Rentabilidade do } \\
\text { Patrimônio }\end{array}$} & \multirow{2}{*}{$\begin{array}{l}\text { Capital } \\
\text { circulante } \\
\text { líquido (em } \\
\text { US\$ } \\
\text { milhões) }\end{array}$} & \multirow{2}{*}{$\begin{array}{l}\text { Liquidez } \\
\text { geral } \\
\left(\mathrm{em} \mathrm{n} \mathrm{n}^{\circ}\right. \\
\text { índice })\end{array}$} & \multicolumn{2}{|c|}{ Endividamento } & \multirow{2}{*}{$\begin{array}{l}\text { Riqueza } \\
\text { criada } \\
\text { (em US\$ } \\
\text { milhões) }\end{array}$} & \multirow{2}{*}{$\begin{array}{l}\mathrm{N}^{\mathrm{o}} \mathrm{de} \\
\text { empre } \\
\text { gados }\end{array}$} & \multirow{2}{*}{$\begin{array}{l}\text { Riqueza } \\
\text { por } \\
\text { emprega } \\
\text { do (em } \\
\text { US\$ mil) }\end{array}$} \\
\hline & $\begin{array}{l}\text { Valor } \\
\text { (em US\$ } \\
\text { milhões) }\end{array}$ & $\begin{array}{l}\text { Crescim } \\
\text { ento } \\
(\%)\end{array}$ & $\begin{array}{l}\text { Líquido } \\
\text { ajustado } \\
\text { (em US\$ } \\
\text { milhões) }\end{array}$ & $\begin{array}{l}\text { Líquido } \\
\text { legal (em } \\
\text { US\$ } \\
\text { milhões) }\end{array}$ & $\begin{array}{l}\text { Líquido } \\
\text { ajustado } \\
\text { (em US\$ } \\
\text { milhões) }\end{array}$ & $\begin{array}{l}\text { Líquido } \\
\text { legal (em } \\
\text { US\$ } \\
\text { milhões) }\end{array}$ & $\begin{array}{l}\text { Ajustado } \\
\text { (em \%) }\end{array}$ & $\begin{array}{l}\text { Legal } \\
\text { (em } \\
\%)\end{array}$ & & & $\begin{array}{l}\text { Geral } \\
\text { (em } \\
\%)\end{array}$ & $\begin{array}{l}\text { Longo } \\
\text { Prazo } \\
(\mathrm{em} \%)\end{array}$ & & & \\
\hline 00 & 379,1 & 2,2 & 285,3 & 258,9 & 24,9 & 41,9 & 8,4 & 15,6 & 154,9 & 1,84 & 31,3 & 14,4 & 182,9 & 2230 & 79,3 \\
\hline 01 & 447,7 & 17,4 & 260,6 & 247,4 & 25,4 & 35,8 & 8,9 & 13,1 & 113,9 & 1,6 & 32,9 & 14,3 & 198,9 & 2401 & 85,9 \\
\hline 02 & 381,6 & $-8,4$ & 246,4 & 231,7 & 25,2 & 32 & 9,5 & 12,8 & 106,4 & 1,93 & 30 & 10 & 175,2 & 2386 & 73,2 \\
\hline 03 & 351,1 & $-8,6$ & 235,3 & 208,3 & 12,8 & 32,9 & 5,1 & 14,7 & 104,3 & 1,69 & 36 & 13,5 & 175,8 & 2475 & 72,3 \\
\hline 04 & 360,8 & $-5,5$ & 112,5 & 102,7 & 4 & 12,3 & 3,4 & 11,6 & 69 & 0,93 & 65,8 & 34,6 & 165,3 & 2532 & 66 \\
\hline 05 & 587,8 & 33,1 & 139,9 & 134,4 & 20,3 & 29,6 & 13,8 & 20,9 & 144,9 & 1,06 & 66,3 & 40,4 & 249,8 & 2592 & 97,5 \\
\hline
\end{tabular}

Fonte: EXAME: melhores e maiores (entre 2000 e 2005)

O crescimento das vendas mostra a evolução da receita bruta de vendas em reais, descontada a inflação média apontada pela variação do IGPM. O endividamento a longo prazo é expresso em porcentagem, em relação ao ativo total ajustado. O endividamento geral é a soma do passivo circulante (dívidas e obrigações de curto prazo, incluindo-se as duplicatas descontadas) com o exigível a longo prazo, sendo o resultado mostrado em porcentagem em relação ao ativo ajustado e representa a participação de recursos financiados por terceiros na operação da empresa.

O exigível a longo prazo é obtido da multiplicação do ativo total ajustado pelo índice de endividamento a longo prazo. A liquidez geral mostra uma relação entre os recursos da empresa que não estão imobilizados (ativo permanente) e o total de sua dívida. O lucro líquido ajustado é apurado depois de reconhecidos os efeitos da inflação nas demonstrações contábeis. O lucro líquido legal é o resultado nominal do exercício depois de descontada a provisão para o imposto de renda e a contribuição social e ajustados os juros sobre o capital próprio, considerados como despesas financeiras. O patrimônio líquido legal é a soma do capital, das reservas, dos lucros acumulados e dos resultados de exercícios futuros, menos a soma do capital a integralizar, das ações em tesouraria, dos prejuízos acumulados e das despesas de variação cambial registradas no ativo diferido, sem considerar a inflação.

O patrimônio líquido ajustado é o patrimônio líquido legal atualizado pelos efeitos da inflação. A rentabilidade do patrimônio mede o retorno sobre o investimento para os acionistas e resulta da divisão do lucro líquido ajustado pelo patrimônio líquido ajustado. A riqueza criada representa a contribuição da empresa na formação do produto interno bruto do país. 
As operações fora do Brasil (Argentina, Chile, Bolívia e Paraguai), mais as exportações, representam faturamento de US\$ 100 milhões. Isso claramente demonstra a estratégia de internacionalização da empresa e, peculiarmente, deduz-se como uma grande empresa nacional opera para conseguir divisas, ou seja, é mais interessante abrir uma filial em outro país do que obter empréstimos necessários ao crescimento interno, mesmo com incentivo à exportação e programas de redução fiscal. Além disso, pode-se constatar aumento das vendas de 2004 para 2005, de 33,1\%, acompanhado de $110 \%$ de aumento do capital circulante líquido e $51 \%$ da riqueza criada pela empresa.

Esses dados demonstram que tanto o segmento de transformados plásticos, quanto a empresa estudada navegam por uma onda de crescimento que não se constatava desde o início da década de 2000.

Continuando a incursão na realidade onde ocorreu o estudo, será abordada a unidade fabril da empresa onde se localiza a unidade de análise.

\subsubsection{A unidade de Rio Claro}

Como dito anteriormente, a unidade da empresa localizada em Rio Claro figura como umas das fábricas mais modernas no planeta e iniciou seu funcionamento em setembro de 1975. Atualmente, conta com 947 funcionários, obtendo faturamento anual bruto de $\mathrm{R} \$ 800$ milhões, através de uma produção anual de 90.000 ton/ano. Isso confere a esta unidade $60 \%$ da participação relativa no faturamento da empresa como um todo. A unidade destina-se majoritariamente ao consumo interno, apenas $5 \%$ da produção é exportado. E os investimentos realizados entre 2000 e 2005 representam média de R\$ 10 milhões por ano. A Figura 57 demonstra o organograma da unidade de Rio Claro.

Em seguida, será descrito o centro de distribuição, enfim a unidade de análise do estudo será apresentada.

\subsubsection{O centro de distribuição}

O centro de distribuição, unidade de análise, possui 276 pessoas trabalhando em três turnos. De acordo com a entrevista realizada com o gestor da área, o centro de distribuição opera continuamente e possui uma estrutura organizacional de 6 níveis. No topo, encontra-se o coordenador de equipe, abaixo têm-se os assistentes de distribuição, 
um analista de distribuição e, no mesmo nível, mais escriturários administrativos. Abaixo, têm-se os compositores de pedidos e, como colaboradores fundamentais ao bom andamento dos processos da área, têm-se, no sexto nível, os ajudantes gerais. Conforme ilustrado na Figura 58.

Atualmente, os clientes que recebem os produtos e serviços do centro de distribuição são: construtoras, home centers, órgãos públicos, clientes de exportação e clientes de varejo (revenda). Para efeito de gerenciamento, a empresa possui classificação de cada canal de distribuição. Definidos, em boa hora, segundo Rosenbloom (2002) como a organização contatual externa que a administração opera para alcançar seus objetivos de distribuição. A classificação dos canais da empresa são: atacadista, construtor predial, distribuição especial para construtores, exportação, home centers, indústrias, irrigação, operador comercial, representantes, varejo, varejo norte e vendas empresariais.

Para atender tais clientes via os supra citados canais de distribuição, engendram-se fluxo físico, fluxo de informações e o fluxo do processo. Estes fluxos serão abordados em seguida, no intuito de definir o processo logístico abordado. 


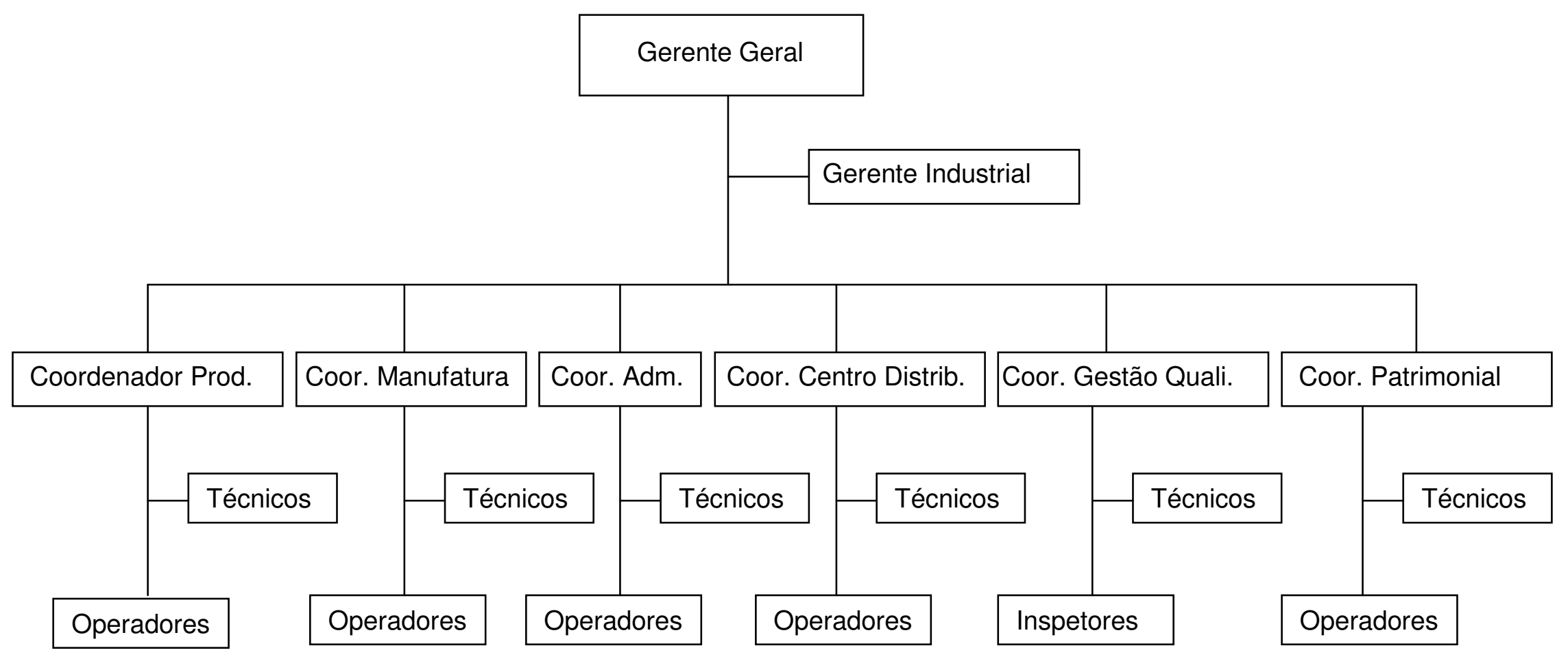

Figura 57 : Organograma da unidade Rio Claro 


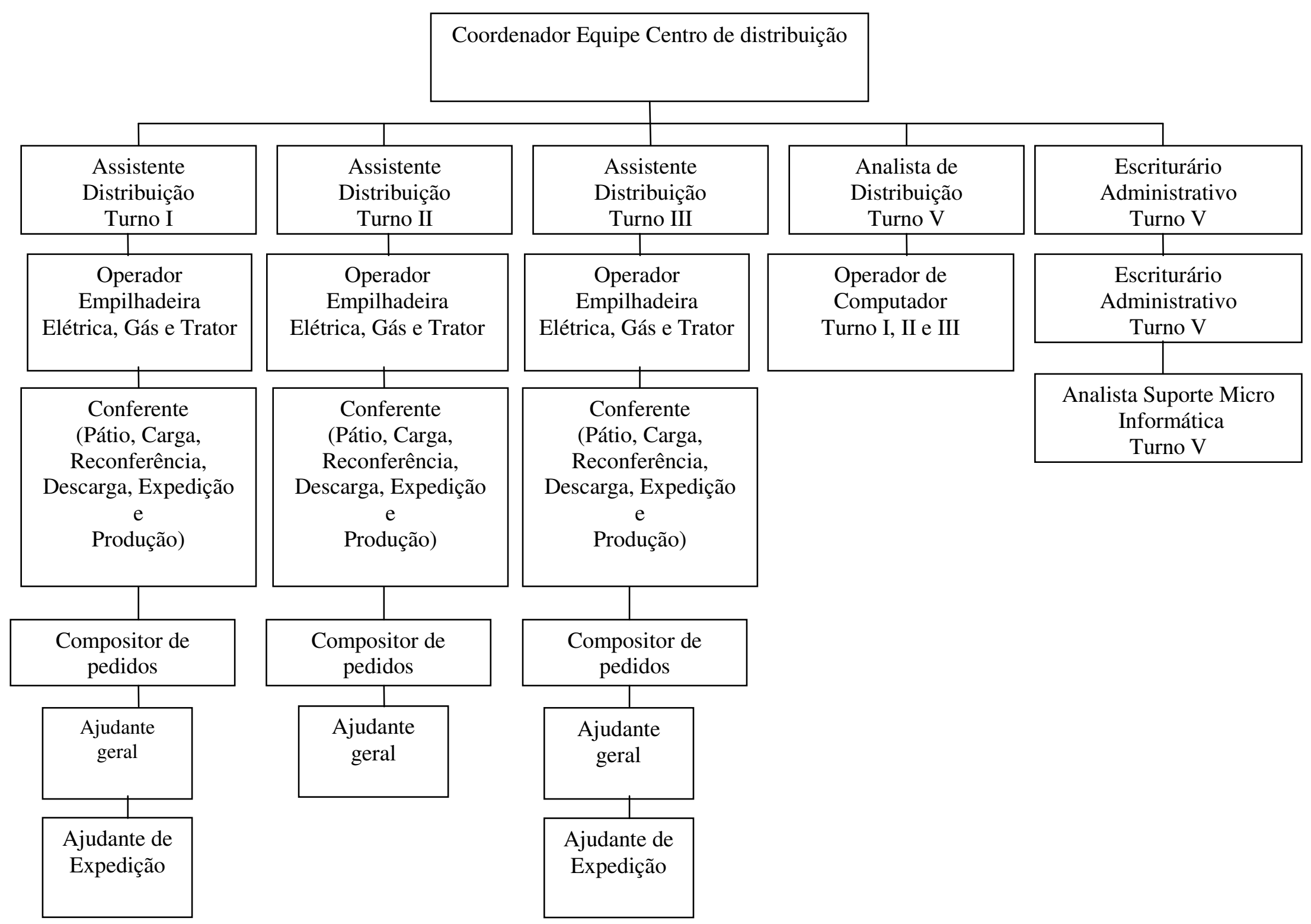

Figura 58 : Organograma do centro de distribuição 


\subsection{O processo logístico}

\subsubsection{Fluxo físico}

De modo sucinto, pode-se descrever o funcionamento do centro de distribuição através do atendimento do pedido. Este chega ao centro de distribuição e, imediatamente, é repassado à área de faturamento e aos agentes das transportadoras que realizam a atividade de transporte. Esses agentes geram uma ou mais pré-notas, e destas criam um manifesto, ou seja, um documento que representa o que deverá ser carregado em cada caminhão. As pré-notas, que, juntas, formam uma nota fiscal, são utilizadas pelos compositores de pedido para separar itens que estejam no armazém.

O funcionamento do fluxo físico possui dois pontos importantes, a seqüência de carregamento no pátio, com os tubos e depois, nas docas, o carregamento das conexões e outros itens, como demonstra a Figura 59. De posse do manifesto, um funcionário do centro de distribuição indica o local onde estão os tubos a ser carregados ao motorista do caminhão. Tal manifesto pode ser itinerante (seqüência de carregamento obedece a ordem de entrega) e não itinerante (seqüência de carregamento aleatória). Além de indicar, esse funcionário confere a quantidade carregada pelos funcionários da transportadora.

Depois que todos os itens de pátio (tubos) foram carregados, o caminhão passa por outra conferência. Caso exista divergência entre o que está no caminhão e o que está no manifesto, realiza-se uma recontagem. Se o número de itens estiver errado, então realizam-se as correções (adicionar ou retirar). Caso esteja correto, o caminhão vai às docas, onde os outros itens (conexões, perfis, caixas d’água, borrachas, e etc.), já separados, são conferidos via coletor de código de barras e, depois, carregados. Depois disso, emite-se a nota fiscal.

Finalmente, depois do caminhão carregado, realiza-se sua pesagem, porque cada item carregado possui um peso estimado com certa margem de erro. Se o peso real for igual ou próximo ao estimado, o caminhão segue viajem. Caso contrário, ele volta à recontagem dos tubos.

Para viabilizar o fluxo físico dos materiais, vários subprocessos ocorrem. Esses subprocessos foram mapeados, medidos e descritos como demonstra o próximo item. 


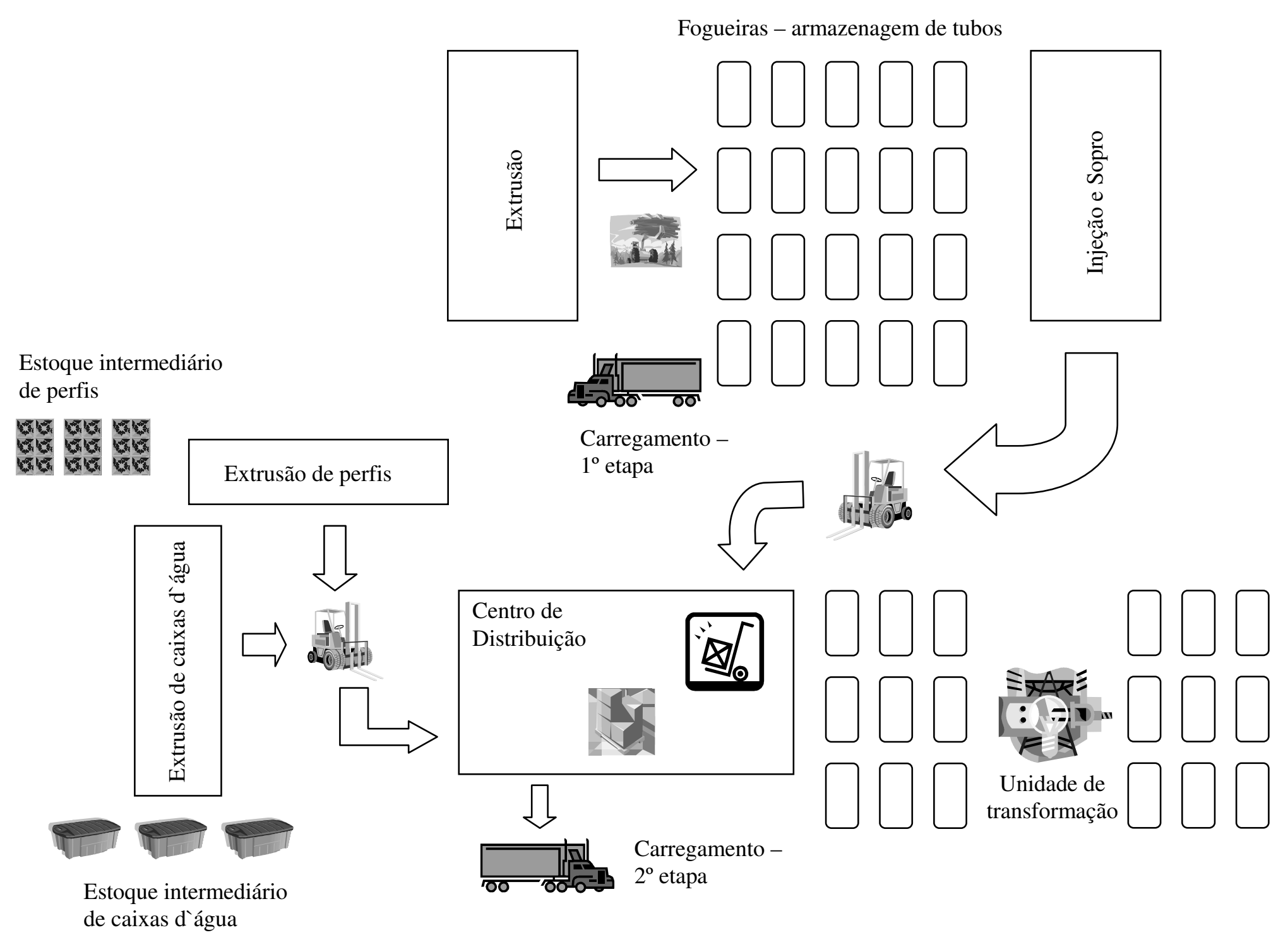

Figura 59 : Fluxo Físico 


\subsubsection{Fluxo do processo}

Devido ao programa de qualidade implantado, o centro de distribuição já possuía uma modelagem de seus subprocessos, conforme Figura 60.

\begin{tabular}{|l|}
\hline Conferência de cargas \\
\hline Pátio - carregamento \\
\hline Pátio - armazenamento \\
\hline Acolhimento produção \\
\hline $\begin{array}{l}\text { Transporte interno - empilhadeira } \\
\text { gás/trator }\end{array}$ \\
\hline $\begin{array}{l}\text { Transporte interno - empilhadeira } \\
\text { elétrica }\end{array}$ \\
\hline Separação de pedidos \\
\hline $\begin{array}{l}\text { Central de embalagem } \\
\text { (embaladoras, link Jet e Manual) }\end{array}$ \\
\hline
\end{tabular}

Figura 60 : Subprocessos do centro de distribuição mapeados pela empresa

Porém, para manter fidelidade ao método utilizado, decidiu-se observar in loco as atividades desenvolvidas no centro de distribuição. Desse trabalho resultou o fluxograma de atividades apresentado na Figura 61. Nessa figura encontram-se informações sobre o tempo médio de execução de cada atividade, o número de pessoas requeridas, as máquinas requeridas e, das não contínuas, suas freqüências, quando mensuráveis. Decidiu-se criar blocos de atividades que reúnem atividades realizadas pelo mesmo funcionário e cujo tempo de execução é de difícil separação. Verificam-se trinta e três (33) blocos de atividades, que representam o fluxo de materiais que saem das fábricas até o carregamento. Informações adicionais podem ser prospectadas, tais como a formação de um manifesto, seus tipos, como são distribuídos os produto que chegam de outras unidades fabris e quais máquinas são utilizadas por mais de uma atividade. 


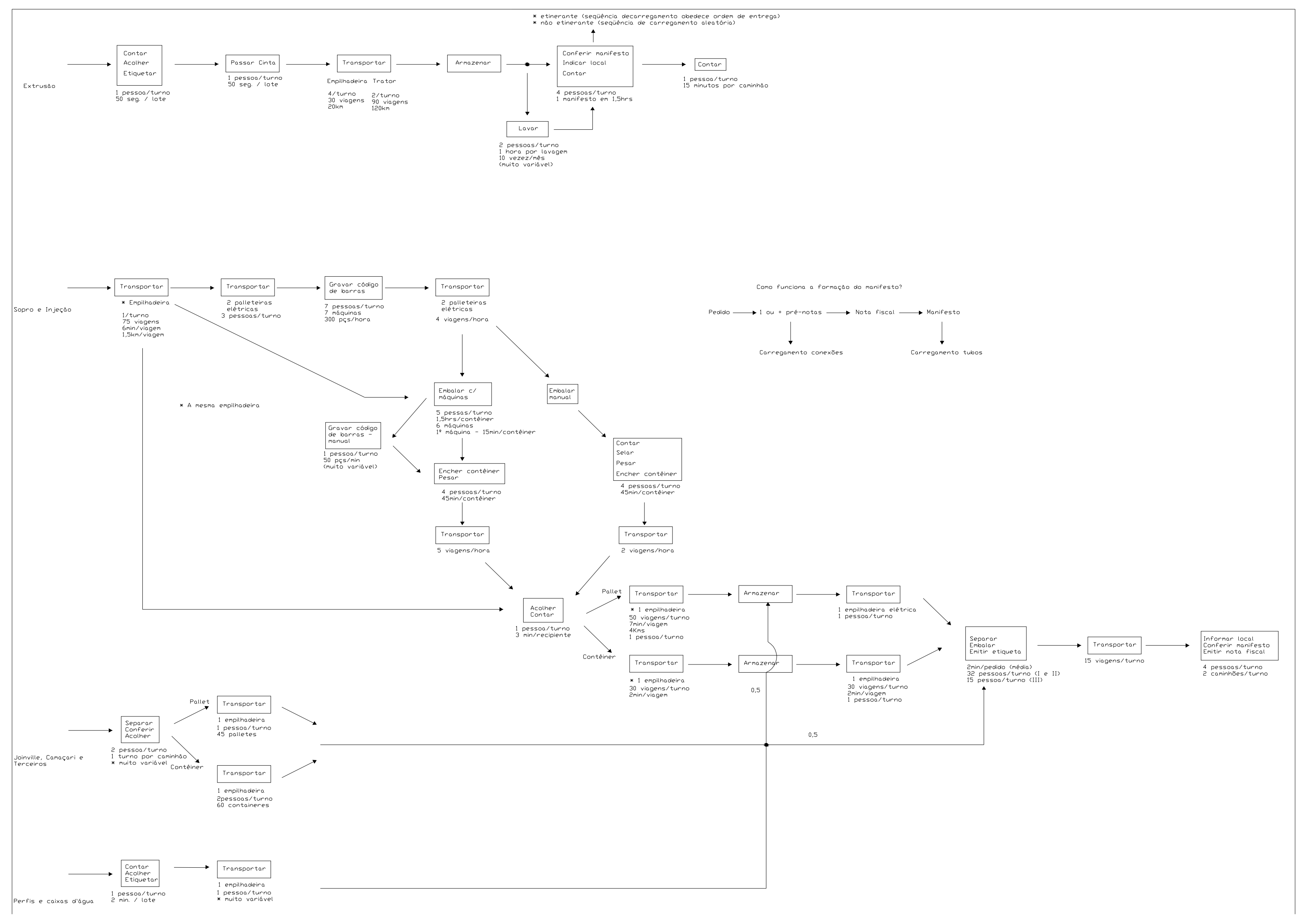

Figura 61: Fluxograma de atividades do Centro de Distribuição 
Em suporte à atividade de carregamento, ocorrem as atividades de faturar, armazenar, manusear, separar, embalar e colacionar. Tais atividades iniciam assim que os produtos deixam as unidades produtivas, divididas por processos titulados como: (1) extrusão, (2) sopro e injeção e (3) extrusão de perfis e caixas d’água. Na Figura 61, no canto inferior direito, vê-se a representação de mais um "processo" que significa os produtos advindos de terceiros, que são armazenados no centro de distribuição.

Inicie-se a explicação pela extrusão. Ao sair em lotes, os itens resultantes do processo de extrusão (tubos) são contados, etiquetados e "apontados". Isso significa que todas as unidades produzidas são registradas, via código de barras, no sistema de gerenciamento da logística. É possível, desse modo, conferir o que foi produzido e o que está em estoque na logística. Depois de etiquetados e "apontados" os lotes são transportados por trator ou empilhadeira até o pátio, aí ficam armazenados em fogueiras (espécie de cavalete formado de tubos em camadas, postos cada um perpendicularmente aos da anterior), até que sejam carregados. Em alguns casos, necessita-se lavar os tubos antes de carregar. Depois que o caminhão está carregado com os tubos, dirige-se à conferência. Caso a carga esteja correta, dirige-se às docas onde as conexões e demais serão carregados.

Antes disso, uma série de outras atividades foram realizadas. Como principal item responsável pela complexidade na formação do pedido, as conexões resultantes do processo de sopro e injeção serão agora abordadas.

Depois de saírem da unidade fabril, já etiquetadas, em caixas e sacos, esperam até que se forme um palete ou contêiner; em seguida, são transportadas até o centro de distribuição. A partir daí, podem tomar três caminhos: ou serão embaladas, ou gravadas com códigos de barras, ou serão armazenadas. Note-se na Figura 61, que todas unidades gravadas são embaladas, e que estas duas atividades podem ser realizadas manualmente ou por máquinas. Depois de gravadas e embaladas, são colocadas em contêineres e transportadas para serem "acolhidas". Isto significa que, assim como os tubos, todas as unidades produzidas serão conferidas e inseridas no sistema de gestão da logística.

Após serem conferidas, são transportadas para serem armazenadas. À medida que os compositores de pedidos vão coletando os produtos no setor de separação, em prateleiras mais baixas das estruturas de armazenagem, os funcionários das empilhadeiras transportam os produtos do estoque armazenado, repondo os produtos no setor de separação. A separação, com certeza, representa a atividade mais variável e 
complexa, já que os compositores se guiam pelas pré-notas para montarem os pedidos. Tais pré-notas variam em quantidade e variedade de itens; se isso não bastasse, os compositores ainda embalam novamente cada micro-lote do pedido, emitem uma etiqueta para cada embalagem (no caso sacos) e transportam os produtos de cada prénota a um local estabelecido para carregamento.

Cada compositor de pedido possui um coletor, aparelho utilizado para ler os códigos de barras das conexões em estoque, que também funciona como guia para montar-se o pedido. O pedido é enviado, via rádio, para os coletores; nesses, o compositor pode escolher um pedido específico (através da identificação do caminhão), ou seguir a fila de pré-notas que o sistema vai criando. O tempo para montar-se uma pré-nota circunda dois (2) minutos, porém, em entrevista realizadas in loco com compositores, uma pré-nota pode levar até um turno para ser preenchida.

Considerações à parte, seguindo-se o fluxograma, depois de separados e transportados até as docas os produtos são mais uma vez "acolhidos", ou seja, conferidos por um funcionário, antes de serem carregados. Por fim, depois de tudo conferido e devidamente registrado no sistema gerencial de informações, o mesmo funcionário que conferiu emite a nota fiscal. Uma guia fica com o motorista do caminhão, outra com o agente da transportadora e outra com os funcionários do centro de distribuição responsáveis pela atividade de faturar.

O último processo da unidade fabril é a extrusão de perfis e caixas d’água. Este, mais simples, demanda apenas dois grupos de atividades. Depois de produzidos são contados, "acolhidos" e etiquetados, para serem transportados ao armazém. De onde em diante, seguem o mesmo fluxo das conexões. Ressalte-se que as atividades logísticas envolvidas neste processo são bastante variáveis em tempo, saída e até em número de funcionários. Apesar de, via de regra, destinarem-se duas pessoas para este processo (uma para transportar e outra para contar, acolher e etiquetar), muitas vezes a mesma pessoa que conta, acolhe e etiqueta, realiza o transporte. Quando isso ocorre as unidades produzidas passaram por considerável tempo de espera para formação de lote.

Em paralelo, ocorre outro fluxo, o dos produtos advindos de outras unidades fabris. Estes são descarregados diretamente no centro de distribuição, e então separados, conferidos e "acolhidos" por duas pessoas. Novamente, depara-se com uma atividade bastante variável em tempo e saída. Segundo entrevistas com os funcionários envolvidos, pode-se descarregar um caminhão em uma hora como em um turno. Em 
alguns casos, têm-se alguns contêineres para ser armazenados, em outros, dezenas. Depois de separados, conferidos e "acolhidos" são transportados para armazenagem ou para o setor de separação (aproximadamente em iguais quinhões para cada possibilidade). Daí em diante seguem o mesmo fluxo das conexões.

Por fim, aborda-se o fluxo de informações para completa visualização dos processos da unidade de análise.

\subsubsection{Fluxo de informações}

O curso das informações tem dois veios cuja nascente é a emissão do pedido. Um dos veios refere-se ao fluxo de informações financeiras e o outro, de informações físico-operacionais. Ambas intentam atender ao pedido. Tal idéia é demonstrada na Figura 62.

Note-se que tais fluxos encontram-se e contribuem para que os produtos sejam separados e expedidos. Porém observe-se que o setor responsável pelo planejamento e controle da produção recebe as ordens de produção (em nivelamento de carga) antes da checagem de condições comerciais do cliente. Logo percebe-se a possibilidade de que um pedido comece a ser produzido, sem que se tenha aprovado o crédito do mesmo.

Na Figura 62, pode-se ver que o fluxo de informações inicia-se quando os pedidos de venda são enviados, diariamente, para o setor comercial, onde é realizada a checagem das condições comerciais dos clientes solicitantes. Segue-se o fluxo pela análise do crédito do cliente e, caso o crédito seja aprovado, a informação retorna ao setor comercial para identificação de propriedades, para que seja realizada a análise dos pedidos.

Tal análise visa confrontar a quantidade de produtos requisitados, com a quantidade em estoque e em produção. Em paralelo, vê-se o fluxo de informações de suprimentos, cujo ponto inicial é o planejamento e controle da produção. Daí, dividi-se em dois sentidos: um, informando para o setor de suprimentos o que e quanto deve ser comprado, e outro, para produção informando o que e quanto dever ser produzido.

Por fim, ao atingir o setor de faturamento do centro de distribuição, duas vezes ao dia, os pedidos geram as notas fiscais e manifestos utilizados para separação dos produtos e posterior expedição. 


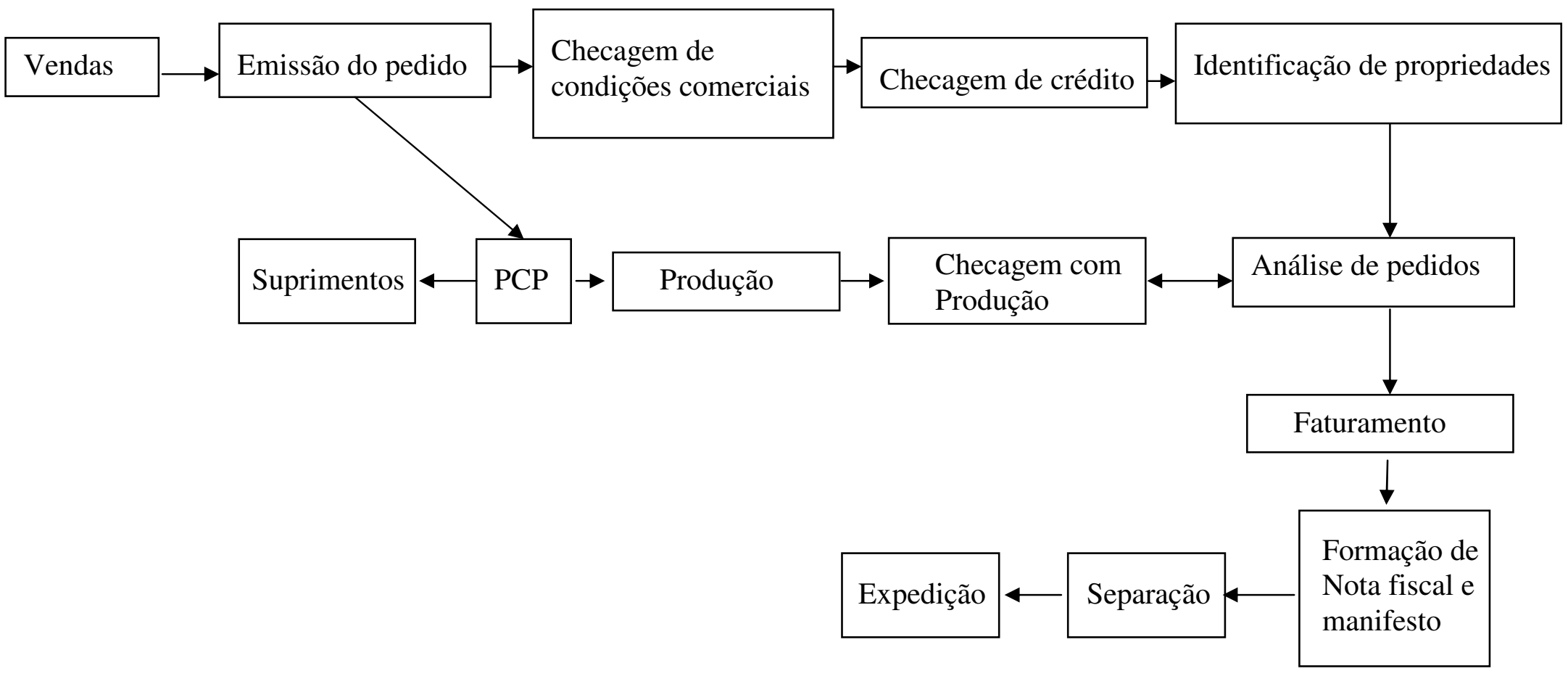

Figura 62 : Fluxo de informações 
Ampliando-se o foco de análise, pode-se enxergar o fluxo de informações na cadeia de suprimentos, como mostra a Figura 63.

Depois de descrito o processo logístico abordado no trabalho, passa-se às atividades. Fulcro da análise de custos, as atividades serão definidas pelos recursos consumidos, tempos e custos.

\subsection{As atividades}

\subsubsection{Recursos das atividades}

Seguindo-se recomendação de Ostrenga et al. (1993), encontrada no guia utilizado neste estudo como base para implementação do método de custeio baseado em atividades, serão definidos grupos de atividades. Tais grupos possuem a mesma causa básica, e não serão feitas distinções entre atividades que agregam valor e que não agregam valor.

O mapeamento das atividades foi feito percorrendo-se o fluxo do processo da unidade de pesquisa, realizando-se perguntas aos funcionários que exerciam a atividade diretamente.

Foram também tomados os tempos reais para a realização de cada atividade. Ressalte-se, porém, que, para algumas atividades, não foi possível realizar tal medição, já que, além de variar bastante em resultado, também ocorria com o tempo. A Figura 61 demonstra o fluxo de atividades realizadas, bem como o número de pessoas envolvidas e o tempo para realização, para o turno referente aos horários entre seis horas e catorze horas. Para esclarecer a quantidade de funcionários nos outros turnos, demonstra-se a Tabela 8. 


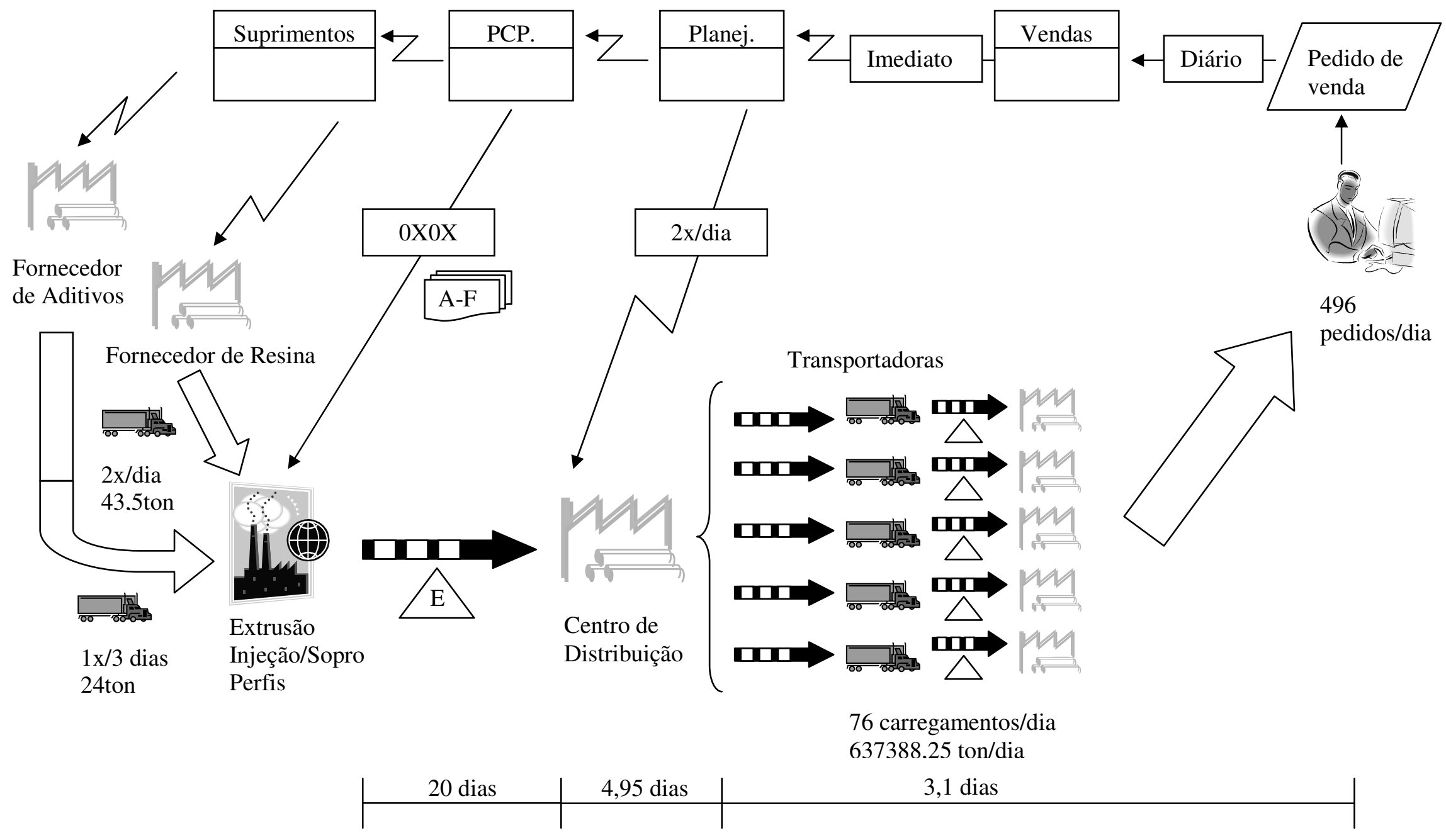

Entregas feitas para região Sudeste, Centro-

Oeste, estados de Roraima e Amazonas.

Figura 63 : Cadeia de suprimentos da unidade pesquisada 
Tabela 8 : Funcionários por turno

\begin{tabular}{lccccc}
\hline & Turno 1 & Turno 2 & Turno 3 & Normal & Total \\
\hline Coordenador & & & & 1 & 1 \\
Ajudante geral & 29 & 52 & 54 & & 135 \\
Ajudante expedição & 1 & & 4 & & 5 \\
Compositor de Pedidos & 4 & 9 & 5 & & 18 \\
Conferente Expedição & 15 & 27 & 17 & 3 & 62 \\
Assistente de distribuição & 1 & 1 & 1 & & 3 \\
Operador empilhadeira elétrica & 5 & 6 & 6 & & 17 \\
Operador/Abast. empilhadeira gás & 4 & 3 & 4 & & 11 \\
Operador empilhadeira gás & 3 & 7 & 4 & & 14 \\
Operador de computador & 1 & 1 & 1 & & 3 \\
Escriturário administrativo & & & & 5 & 5 \\
Analista distribuição & & & & 1 & 1 \\
Analista suporte micro-informática & & & & 1 & 1 \\
Total & 63 & 106 & 96 & 11 & 276 \\
\hline
\end{tabular}

Agruparam-se as atividades em blocos, no intuito de priorizar o fluxo, uma vez que, como dito anteriormente, são realizadas pela mesma pessoa, perfazendo um ponto por onde fluem materiais e informações. Dos trinta e três blocos de atividades mapeados formaram-se sete grupos de atividades: faturar, movimentar 1, movimentar 2, armazenar, colacionar, separar e embalar. Tais grupos baseiam-se numa relação causal de aglutinação, ou seja, as atividades foram agrupadas de acordo a causa de cada uma. Para cada grupo de atividade foram prospectados o número de pessoas, a área ocupada e as máquinas utilizadas. Como ilustra a Tabela 9.

O grupo faturar relaciona-se com atividades administrativas do processo logístico como um todo. O grupo movimentar 1 está ligado ao transporte dos tubos para armazenagem, enquanto movimentar 2, com o transporte para armazenagem das conexões. O grupo armazenar congrega as atividades de lavar e armazenar, e refere-se ao acondicionamento dos produtos (tubos, conexões, caixas d’água e forros) no pátio e no armazém. O grupo colacionar engloba atividades relacionadas à conferência e confrontação do que é produzido, armazenado e carregado. O grupo separar abrange atividades relacionadas ao picking ou separação. O grupo embalar, propriamente, agrega atividades relacionadas ao acondicionamento dos produtos, bem como sua identificação por código de barras.

Ratifique-se que, tais grupos foram criados levando-se em conta a causa básica das atividades neles inclusas. No grupo faturar a causa é o número de pedidos a serem atendidos, em movimentar 1, a quantidade de tubos produzida, em movimentar 2, a quantidade de conexões produzidas, em armazenar, a produção como um todo, em 
Tabela 9: Grupos de atividades

\begin{tabular}{|c|c|c|c|c|}
\hline & & $\begin{array}{l}\text { Número } \\
\text { de } \\
\text { pessoas }\end{array}$ & Área $\left(\mathrm{m}^{2}\right)$ & Máquinas \\
\hline Faturar & $\begin{array}{l}\text { Atividades } \\
\text { administrativas } \\
\text { relacionadas } \\
\end{array}$ & 15 & 576,36 & $\begin{array}{c}12 \mathrm{PC} \text { 's } \\
1 \text { impressora }\end{array}$ \\
\hline \multirow[b]{2}{*}{ Movimentar 1} & Transportar (tubos) & 18 & & \multirow{3}{*}{$\begin{array}{c}3 \text { tratores } \\
4 \\
\text { empilhadeiras } \\
1 \text { impressora } \\
5 \\
\text { empilhadeiras } \\
4 \text { paleteiras } \\
\end{array}$} \\
\hline & Passar Cinta & 3 & & \\
\hline Movimentar 2 & Transportar (conexões) & 24 & & \\
\hline \multirow[b]{2}{*}{ Armazenar } & Armazenar & 23 & 13454,13 & \multirow[b]{2}{*}{$\begin{array}{l}1 \text { bomba } \\
\text { d’água }\end{array}$} \\
\hline & Lavar & 6 & & \\
\hline \multirow{5}{*}{ Colacionar } & $\begin{array}{c}\text { Conferir } \\
\text { manifesto/Indicar local/ } \\
\text { Contar }\end{array}$ & 15 & & \multirow{5}{*}{$\begin{array}{c}1 \text { acolhedor } \\
2 \text { acolhedor } \\
2 \text { impressoras } \\
4 \text { acolhedores } \\
1 \text { PC }\end{array}$} \\
\hline & Contar/Acolher/Etiquetar & 3 & & \\
\hline & Acolher/Contar & 6 & & \\
\hline & $\begin{array}{l}\text { Informar local/Conferir } \\
\text { manifesto/Emitir nota }\end{array}$ & 12 & & \\
\hline & Contar & 3 & & \\
\hline \multirow[t]{2}{*}{ Separar } & $\begin{array}{c}\text { Separar/Embalar/Emitir } \\
\text { etiqueta }\end{array}$ & 79 & & \multirow{2}{*}{$\begin{array}{c}32 \\
\text { acolhedores } \\
4 \text { impressoras } \\
2 \text { acolhedores } \\
1 \text { PC }\end{array}$} \\
\hline & Separar/Acolher/Conferir & 6 & & \\
\hline \multirow{4}{*}{ Embalar } & $\begin{array}{l}\text { Gravar código de } \\
\text { barras/Gravar cód. } \\
\text { manual }\end{array}$ & 24 & \multirow{4}{*}{582,375} & 7 máquinas \\
\hline & Embalar com & & & \\
\hline & $\begin{array}{c}\text { máquinas/Embalar } \\
\text { manual }\end{array}$ & 27 & & 6 máquinas \\
\hline & Pesar/Encher contêiner & 12 & & $\begin{array}{c}2 \text { impressoras } \\
1 \mathrm{PC} \\
\end{array}$ \\
\hline
\end{tabular}

colacionar, o número de acolhimentos, em separar, o número de pré-notas e em embalar, a quantidade de conexões produzidas.

Adicionalmente, prospectou-se do livro-razão as contas relativas ao centro de distribuição referentes ao ano de 2005, mostradas pela Tabela 10, cujos dados foram modificados no intuito de preservar-se a política confidenciosa da empresa. 


\title{
6.3.2 Custos das atividades
}

Depois de definidas as atividades, bem como os grupos a que cada uma pertence, engenha-se a distribuição dos custos do livro-razão para as categorias de atividades. Isso é feito em duas fases; primeiro, procede-se ao exame global à procura de oportunidades para condensar os dados da contabilidade e, em segundo, especificamse as regras para a alocação de custos às atividades. A ultima fase obedece a uma seqüência hierárquica de alocação: direta, com base causal da atividade e baseada em volume.

Alertam Ostrenga et al. (1993, p.182) que

\begin{abstract}
A primeira coisa a questionar em um centro de custos é se há custos dedicados a determinadas atividades e/ou produtos (ou outros objetos de custos). Aqui estão alguns exemplos de candidatos típicos à alocação direta: custos que podem ser alocados diretamente a processos/atividades e custos que podem ser alocados diretamente a produtos ou família de produtos.
\end{abstract}

Deste modo, definem-se as bases para alocação de custos para grupos de custos de atividades, ou seja, os geradores de custos. Isso deve ser feito de maneira tal que o gerador de custos tenha uma relação lógica com sua atividade e sua coleta seja factível. Os geradores escolhidos foram: o número de pessoas, área, potência instalada, número de máquinas e estimativas gerenciais de esforço relativo, como mostra Tabela 9. Na Tabela 11, vêem-se todas as contas relacionados ao centro de custo do centro de distribuição.

Tais contas foram agrupadas em cinco centros de custos: pessoas, armazém, transporte, embalagem e financeiro.

O centro de custo pessoas reúne as contas: salários e encargos, alimentos, ingredientes, assistência educacional, assistência médica, cantina, contribuição para assistência social, contribuições, donativos, previdência privada, refeição pronta, treinamento, assistência técnica e administrativa, outros PA', assinaturas, mensalidades, viagens e estadas. Esta última alocada totalmente às atividades de faturar, e o restante alocado de acordo o número de pessoas em cada atividade. 


\begin{tabular}{|c|c|c|c|c|c|c|c|c|c|c|c|c|c|}
\hline & Janeiro & Fevereiro & Março & Abril & Maio & Junho & Julho & Agosto & Setembro & Outubro & Novembro & Dezembro & Total \\
\hline Água & 3,8 & 3,8 & 17,3 & 3,8 & 4,4 & 4,6 & 2,95 & 5,85 & 2,95 & 4,4 & 10,4 & 4,4 & 68,65 \\
\hline Alimentos, ingredientes & 1216,9 & 1340,25 & 535,05 & 2252,85 & 1594,45 & 1453,3 & 1415,95 & 1363,05 & 1524,45 & 1540,8 & 1497,25 & 1827,9 & 17562,2 \\
\hline Aluguéis & 0 & 660 & 0 & 0 & 0 & 0 & 44,9 & 0 & 6,65 & 0 & 3,9 & 200,8 & 916,25 \\
\hline Assinaturas,mensalidades & 0 & 0 & 13,1 & 0 & 0 & 0 & 0 & 0 & 13,1 & 0 & 0 & 0 & 26,2 \\
\hline Assistência Técnica e adm. & 233,55 & 129,55 & 558,6 & 877,4 & 872,65 & 855,75 & 962,2 & 986,8 & 391,1 & 153,5 & 133,7 & 512,05 & 6666,85 \\
\hline Assistência educacional & 60,5 & 40,15 & 67,1 & 64,55 & 64,55 & 64,55 & 69,2 & 62,7 & 74,55 & 64,8 & 74,55 & 54,55 & 761,75 \\
\hline Assistência médica & 1778,45 & 3135,7 & 1982,85 & 1825,1 & 2199,25 & 2156,15 & 5898,65 & 2089,3 & 5451,1 & 2279,3 & 2281,2 & 2726,15 & 33803,2 \\
\hline Cantina & 50,75 & 49,55 & 179,65 & 181,7 & 68,35 & 59,55 & 71,45 & 151,15 & 137,35 & 155,55 & 116,35 & 97,8 & 1319,2 \\
\hline Combustíveis, Lubrificantes & 387,35 & 439,35 & 492,95 & 531,9 & 492,7 & 417,8 & 352 & 434,65 & 535,3 & 407,1 & 619,75 & 503,75 & 5614,6 \\
\hline Comunicações & 340,4 & 222,85 & 223,35 & 215,25 & 352,45 & 367,1 & 217,45 & 220,25 & 385,2 & 221,5 & 247,65 & 240,2 & 3253,65 \\
\hline Condução & 1,45 & 7,05 & 2,25 & 1,4 & 0 & 2,6 & 18,7 & 3 & 2,55 & 3,75 & 17,4 & 13,7 & 73,85 \\
\hline Conservação e limpeza & 1262,35 & 2396,65 & 1324,15 & 774,3 & 1070,8 & 942,1 & 1060,35 & 934,8 & 1375 & 1260,4 & 1176,45 & 1586,7 & 15164,05 \\
\hline Contrib. Assist. social & 152,55 & 34,65 & 172,9 & 163,6 & 32,15 & 282,85 & 215,45 & 237,5 & 119,75 & 330,25 & 226 & 34,95 & 2002,6 \\
\hline Contribuições, Donativos & 0,55 & 0,35 & 0 & 0 & 0,05 & 0 & 0,2 & 0,65 & 0,45 & 0,1 & 3,6 & 9,75 & 15,7 \\
\hline Despesas com veículos & 1363,4 & 717,95 & 717,2 & 1134,95 & 1235 & 1244,5 & 790,3 & 1025,7 & 1098,5 & 1497,05 & 1063,05 & 1478,15 & 13365,75 \\
\hline Despesas legais & 0 & 4,9 & 0,8 & 12,7 & 0 & 3,3 & 11,25 & 1,45 & 6,7 & 0 & 0,9 & 0 & 42 \\
\hline Energia elétrica & 369,35 & 513,45 & 529,7 & 523,15 & 488,1 & 450,55 & 477,45 & 531,95 & 626,05 & 735 & 702,45 & 671,2 & 6618,4 \\
\hline Equipa. Prot. Individual & 60,8 & 82,15 & 102,75 & 52,4 & 60,95 & 49,4 & 50,05 & 69,55 & 96,35 & 81,75 & 69,55 & 81,6 & 857,3 \\
\hline Equipa. Escritório & 20 & 0 & 0 & 0 & 34,5 & 0 & 0 & 0 & 0 & 0 & 0 & 0 & 54,5 \\
\hline Fretes & 6,8 & 2,95 & 17,85 & 69,4 & 339,45 & 7,5 & 13,7 & 19,15 & 8,7 & 5,8 & 11,35 & 87,75 & 590,4 \\
\hline IPI não ressarcido & 654,75 & 324,85 & 173,15 & 264,7 & 838,9 & 121,5 & 2566,2 & 163,65 & 111,75 & 141,6 & 95,85 & 1192,6 & 6649,5 \\
\hline Manutenção & 303 & 208,4 & 272,2 & 68,25 & 460,55 & 286,15 & 51,25 & 516,4 & 284 & 167,5 & 216,7 & 412,65 & 3247,05 \\
\hline Materiais indiretos & 148,4 & 519,25 & 570,15 & 145,5 & 490,5 & 200,1 & 269,85 & 231,7 & 370 & 325,75 & 77 & 212,85 & 3561,05 \\
\hline Material de consumo & 468,35 & 34893,95 & 45587,65 & $-19448,5$ & $-48946,1$ & 3040,7 & 497,15 & 770,15 & 273 & 823,05 & 8013,65 & $-1242,2$ & 24730,85 \\
\hline Material de embalagem & 37,2 & 148,35 & 0 & 342,45 & 550,95 & 0 & 0 & 13,7 & 38,05 & 0 & 37,95 & 274,35 & 1443 \\
\hline Material de expediente & 352,15 & $-155,65$ & 56,9 & 41,3 & 87,05 & 86,35 & 85,05 & 62,7 & 92,4 & 23,55 & 46,2 & 83,1 & 861,1 \\
\hline Outros PA' & 541,45 & 538,95 & 598,95 & 595,25 & 584,4 & 528,65 & 514,8 & 522,05 & 511,9 & 490,45 & 493,1 & 502,75 & 6422,7 \\
\hline Outros Tributos & 641,2 & 0 & 247,35 & 0 & 222,55 & 0 & 0 & 0 & 0 & 0 & 0 & 878,9 & 1990 \\
\hline Perda ICMS s/ Imobilizado & 62,7 & 0 & 86,75 & 180,2 & 0,95 & 0 & 2,9 & 4,25 & 20,9 & 0 & 0 & 0,4 & 359,05 \\
\hline Previdência privada & 4,55 & 4,55 & 4,55 & 4,55 & 4,55 & 4,55 & 4,55 & 4,55 & 4,55 & 4,55 & 4,55 & 18,3 & 68,35 \\
\hline Processamento de dados & 420,45 & 328,55 & 485,55 & 475,75 & 345 & 32,5 & 692,45 & 670,45 & 840,25 & 751,9 & 471,95 & 572,15 & 6086,95 \\
\hline Proteção contra incêndio & 0 & 0 & 0 & 0 & 0 & 0 & 0 & 38,9 & 0 & 0 & 0 & 0 & 38,9 \\
\hline Refeição Pronta & 0 & 0 & 0 & 0 & 0 & 0 & 5,4 & 30,6 & 0 & 0 & 0 & 0 & 36 \\
\hline $\begin{array}{l}\text { Repres e promoções } \\
\text { Continua }\end{array}$ & 65,05 & 0 & 0 & 0 & 0 & 0 & 22,2 & 0 & 5,8 & 0 & 277,55 & 105,55 & 476,15 \\
\hline
\end{tabular}


Salários e encargos

Seguros

Transporte operacional

Treinamento

Uniformes

Viagens e estadas

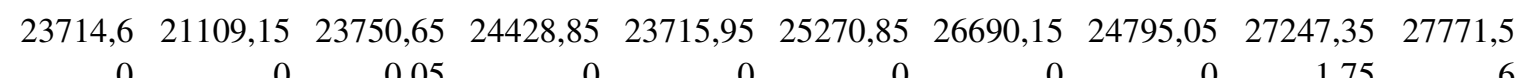

$\begin{array}{rrrr}0 & 0 & 0,05 & \\ 341,2 & 406,3 & 501,55 & 485,05 \\ 0 & 0 & 8,65 & \\ 35 & 38,15 & 102,65 & \\ 0 & 0 & 0 & \end{array}$

$\begin{array}{ll}0 & 0\end{array}$

466, 4

0

58,3
49,8

500,3

52,35
459,85

496,2

$500,35 \quad 553,15$

53,9
3,55

43,3

$28,2 \quad 31,75$

$\begin{array}{rr}65,5 & 76 \\ 0 & 0\end{array}$

47,6 $\begin{array}{rrrr}0 & 1,75 & 6\end{array}$
32511,6

577,7

62,85

66,05

16,25
$30752,95 \quad 311758,7$

$614,55 \quad 5902,6$

$47,6 \quad 222,35$

$61,4 \quad 738,9$

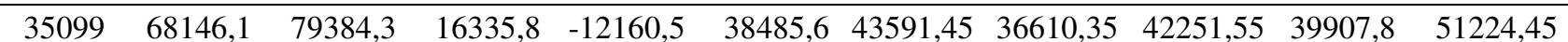


Tabela 11 : Custos das Atividades

\begin{tabular}{|c|c|c|c|c|c|c|}
\hline & Faturar & Transportar (tubos) & Passar Cinta & $\begin{array}{l}\text { Transportar } \\
\text { (conexões) }\end{array}$ & Armazenar & Lavar \\
\hline Total & & & & & & \\
\hline
\end{tabular}

Recursos

\section{Pessoas}

\begin{tabular}{lccccccc}
\hline Total & 380782,95 & 20694,72554 & 24833,67065 & 4138,945109 & 33111,56087 & 31731,9125 & 8277,890217 \\
\hline Viagens & 100,95 & 100,95 & 0 & 0 & 0 & 0 & 0 \\
\hline
\end{tabular}

\section{Armazém}

\begin{tabular}{|c|c|c|c|c|c|c|c|}
\hline Água & 68,65 & 3,730978261 & 4,477173913 & 0,746195652 & 5,969565217 & 5,720833333 & 1,492391304 \\
\hline Alugueis & 916,25 & 10,06580736 & 0 & 0 & 0 & 896,0133366 & 0 \\
\hline Comunicações & 3253,65 & 176,8288043 & 212,1945652 & 35,36576087 & 282,926087 & 271,1375 & 70,73152174 \\
\hline Conservação e limpeza & 15164,05 & 166,5903478 & 0 & 0 & 0 & 14829,13074 & 0 \\
\hline Condução & 73,85 & 59,08 & 0,96326087 & 0,160543478 & 1,284347826 & 1,230833333 & 0,321086957 \\
\hline Despesas legais & 42 & 42 & 0 & 0 & 0 & 0 & 0 \\
\hline Energia elétrica & 6618,4 & 827,3 & 0 & 0 & 0 & 330,92 & 165,46 \\
\hline Equipa. Prot. Individual & 857,3 & 46,5923913 & 55,91086957 & 9,318478261 & 74,54782609 & 71,44166667 & 18,63695652 \\
\hline Equipa. Escritório & 54,5 & 54,5 & 0 & 0 & 0 & 0 & 0 \\
\hline Materiais indiretos & 3561,05 & 0 & 0 & 0 & 0 & 0 & 0 \\
\hline Material de consumo & 24730,85 & 4871,22803 & 0 & 0 & 0 & 0 & 0 \\
\hline Material de expediente & 861,1 & 169,6106061 & 0 & 0 & 0 & 0 & 0 \\
\hline Proteção contra incêndio & 38,9 & 0,427350512 & 0 & 0 & 0 & 38,04083907 & 0 \\
\hline Seguros & 7,8 & 0,08568982 & 0 & 0 & 0 & 7,627726085 & 0 \\
\hline Uniformes & 738,9 & 40,1576087 & 48,18913043 & 8,031521739 & 64,25217391 & 61,575 & 16,06304348 \\
\hline Processamento de dados & 6086,95 & 1198,944697 & 0 & 0 & 0 & 0 & 0 \\
\hline Repres e promoções & 476,15 & 476,15 & 0 & 0 & 0 & 0 & 0 \\
\hline Transporte & 28720,4 & 0 & 12565,175 & 0 & 16155,225 & 0 & 0 \\
\hline Embalagens & 1443 & 0 & 0 & 0 & 0 & 0 & 0 \\
\hline
\end{tabular}




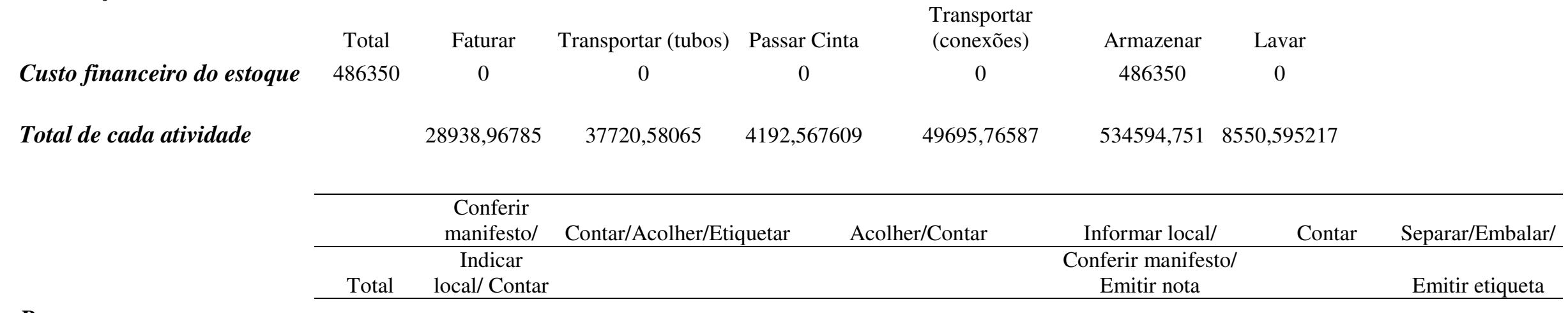

\section{Recursos}

\section{Pessoas}

\begin{tabular}{lccccccc}
\hline Total & 380782,95 & 20694,72554 & 4138,945109 & 8277,890217 & 16555,78043 & 4138,945109 & 108992,2212 \\
\hline Viagens & 100,95 & 0 & 0 & 0 & 0 \\
\hline
\end{tabular}

\section{Armazém}

\begin{tabular}{|c|c|c|c|c|c|c|c|}
\hline Água & 68,65 & 3,730978261 & 0,746195652 & 1,492391304 & 2,984782609 & 0,746195652 & 19,64981884 \\
\hline Alugueis & 916,25 & 0 & 0 & 0 & 0 & 0 & 0 \\
\hline Comunicações & 3253,65 & 176,8288043 & 35,36576087 & 70,73152174 & 141,4630435 & 35,36576087 & 931,2983696 \\
\hline Conservação e limpeza & 15164,05 & 0 & 0 & 0 & 0 & 0 & 0 \\
\hline Condução & 73,85 & 0,802717391 & 0,160543478 & 0,321086957 & 0,642173913 & 0,160543478 & 4,227644928 \\
\hline Despesas legais & 42 & 0 & 0 & 0 & 0 & 0 & 0 \\
\hline Energia elétrica & 6618,4 & 0 & 264,736 & 264,736 & 264,736 & 0 & 264,736 \\
\hline Equipa. Prot. Individual & 857,3 & 46,5923913 & 9,318478261 & 18,63695652 & 37,27391304 & 9,318478261 & 245,3865942 \\
\hline Equipa. Escritório & 54,5 & 0 & 0 & 0 & 0 & 0 & 0 \\
\hline Materiais indiretos & 3561,05 & 0 & 0 & 0 & 0 & 0 & 0 \\
\hline Material de consumo & 24730,85 & 0 & 749,419697 & 749,419697 & 2622,968939 & 0 & 13864,26439 \\
\hline Material de expediente & 861,1 & 0 & 26,09393939 & 26,09393939 & 91,32878788 & 0 & 482,7378788 \\
\hline Proteção contra incêndio & 38,9 & 0 & 0 & 0 & 0 & 0 & 0 \\
\hline Seguros & 7,8 & 0 & 0 & 0 & 0 & 0 & 0 \\
\hline Uniformes & 738,9 & 40,1576087 & 8,031521739 & 16,06304348 & 32,12608696 & 8,031521739 & 211,4967391 \\
\hline
\end{tabular}

Uniformes

8,031521739

16,06304348

$\frac{0}{32,12608696}$ 


\begin{tabular}{|c|c|c|c|c|c|c|c|}
\hline & Total & $\begin{array}{c}\text { Conferir } \\
\text { manifesto/ }\end{array}$ & Contar/Acolher/Etiquetar & Acolher/Contar & Informar local/ & Contar & Separar/Embalar/ \\
\hline & & $\begin{array}{c}\text { Indicar } \\
\text { local/ Contar } \\
\end{array}$ & & & $\begin{array}{c}\text { Conferir manifesto/ } \\
\text { Emitir nota }\end{array}$ & & Emitir etiqueta \\
\hline Processamento de dados & 6086,95 & 0 & 184,4530303 & 184,4530303 & 645,5856061 & 0 & 3412,381061 \\
\hline Repres e promoções & 476,15 & 0 & 0 & 0 & 0 & 0 & 0 \\
\hline Transporte & 28720,4 & 0 & 0 & 0 & 0 & 0 & 0 \\
\hline Embalagens & 1443 & 0 & 0 & 0 & 0 & 0 & 577,2 \\
\hline Custo financeiro do estoque & 486350 & 0 & 0 & 0 & 0 & 0 & 0 \\
\hline Total de cada atividade & & 20962,84 & 5417,27 & 9609,84 & 20394,89 & 4192,57 & 129005,6 \\
\hline
\end{tabular}

\begin{tabular}{|c|c|c|c|c|c|}
\hline & Separar/Acolher/ & $\begin{array}{c}\text { Gravar código de } \\
\text { barras/ }\end{array}$ & $\begin{array}{c}\text { Embalar } \\
\text { com } \\
\text { máquinas/ }\end{array}$ & Pesar/Encher contêiner & Total \\
\hline Total & Conferir & $\begin{array}{c}\text { Gravar código } \\
\text { manual }\end{array}$ & $\begin{array}{c}\text { Embalar } \\
\text { manual }\end{array}$ & & \\
\hline
\end{tabular}

\section{Recursos}

\begin{tabular}{|l|c|c|c|c|c|c|}
\hline Pessoas & & & & & & \\
\hline & & & & & & \\
\hline Total & 380782,95 & 8277,890217 & 33111,56087 & 37250,50598 & 16555,78043 & 380782,95 \\
\hline Viagens & 100,95 & 0 & 0 & 0 & 0 & 100,95 \\
\hline
\end{tabular}

\begin{tabular}{|l|c|c|c|c|c|c|}
\hline Armazém & & & & & & \\
\hline & & & & & & \\
\hline Água & 68,65 & 1,492391304 & 5,969565217 & 6,71576087 & 2,984782609 & 0 \\
\hline Alugueis & 916,25 & 0 & 0 & 10,170856 & 0 & 916,25 \\
\hline Comunicações & 3253,65 & 70,73152174 & 282,926087 & 318,2918478 & 141,4630435 & 3253,65 \\
\hline Conservação e limpeza & 15164,05 & 0 & 0 & 168,3289156 & 0 & 15164,05 \\
\hline Condução & 73,85 & 0,321086957 & 1,284347826 & 1,444891304 & 0,642173913 & 73,04728261 \\
\hline
\end{tabular}




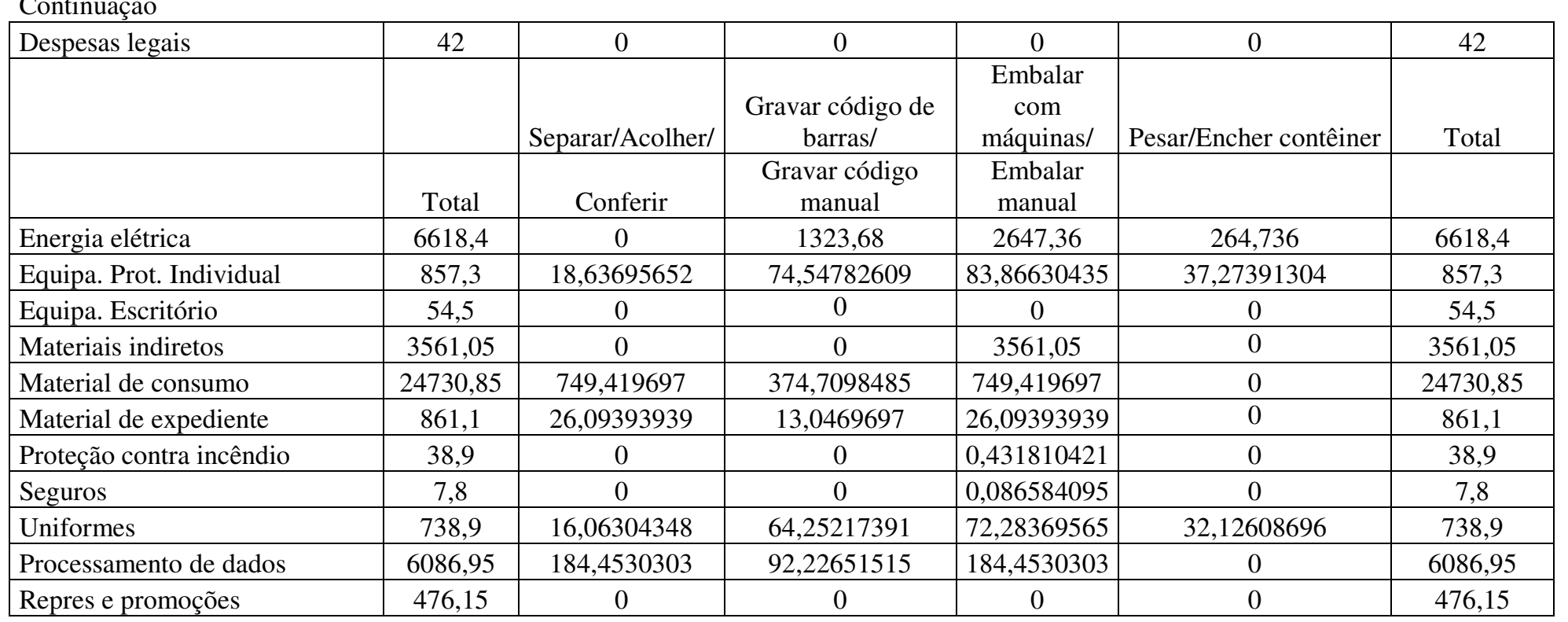

\section{Transporte}

Embalagens

Custo financeiro do estoque

Total de cada atividade
486350

28720,4

0

0

0

9345,101884
0

0

0

35344,2042
0

865,8

0
0

28720,4

1443

(0)

486350

$45946,30331 \quad 17035,00643 \quad 960878,1973$ 
O centro de custo armazém é constituído das contas de: água, aluguéis, comunicações, conservação e limpeza, condução, despesas legais, energia elétrica, equipamentos de proteção individual (EPI), equipamento de escritório, materiais indiretos, material de consumo, material de expediente, proteção contra incêndio, seguros, uniformes, processamento de dados e representações e promoções. Aqui, diferentes geradores de custos foram utilizados:

- as contas de despesas legais, equipamento de escritório, e representantes e promoções foram alocadas diretamente para atividade de faturar;

- para aluguéis, conservação e limpeza, proteção contra incêndio e seguros utilizou-se como gerador a área ocupada pelas atividades;

- para comunicações, equipamentos de proteção individual e uniformes utilizou-se, como gerador, o número de pessoas empregada pelas atividades;

- para processamento de dados, material de consumo e material de expediente, utilizou-se, como gerador, o número de máquinas eletrônicas (PC's - computadores pessoais, impressoras e acolhedores) de cada atividade;

O centro de custo transporte constitui-se das contas combustíveis, lubrificantes, despesas com veículos, manutenção, transporte operacional e fretes. O gerador de custos utilizado foi o número de máquinas de transporte (tratores, empilhadeiras e paleteiras) utilizadas por cada atividade. Já o centro de custo embalagem teve sua conta, material de embalagem, dividida em proporção de 1:1,5 entre os grupos de atividades Separar/Embalar/Emitir etiqueta e Embalar com máquinas/Embalar manual. Tal proporção, aproximada, foi prospectada junto ao gerente do centro de distribuição, bem como verificada em um turno, através de pesagem do estoque de embalagens.

Pelos dados apresentados acima, pode-se checar que a atividade que mais consome recursos é armazenar, principalmente devido ao custo financeiro do estoque. A segunda atividade mais custosa refere-se à separação.

Após apresentados os custos das atividades, realizados através do método de custeio baseado em atividades adotado, faz-se necessário meditar sobre as informações geradas. Para isso, serão feitas análises de evidências do estudo de caso. Tais análises 
incluem análise de séries temporais, realização de um construto explicativo e adequação ao padrão.

\subsection{Considerações}

Até o momento, tem-se: o problema da pesquisa, os dados de custos das atividades de logística de distribuição e um fluxograma detalhado delas. Para comprovar a hipótese, necessita-se de uma estratégia geral analítica, cuja meta principal é tratar a evidência, imparcialmente, para produzir conclusões atrativas, e impedir interpretações alternativas.

Yin (2001, p. 133) enumera duas de tais estratégias: fiar-se em proposições teóricas e desenvolver uma descrição do caso. De pronto, anuncia-se que a primeira será adotada. Isto significa seguir as proposições teóricas que levaram ao estudo de caso. Claramente, as proposições ajudam tanto a focar atenção em certos dados e ignorar outros, quanto a organizar todo o estudo de caso e definir explicações alternativas a ser examinadas. Proposições teóricas sobre relações causais - respostas para questões do tipo "como" e "por que" -, argumenta o autor, podem ser bastante úteis no direcionamento da análise do estudo de caso.

A segunda estratégia analítica geral consiste em desenvolver uma estrutura descritiva para organizar o estudo de caso; nesse sentido o caminho descritivo pode ser usado para identificar um tipo de evento que pode ser quantificado e um padrão geral de complexidade basicamente usado num senso causal para explicar o "por quê" do caso.

Desse modo, os dados apresentados adiante visam elucidar as relações entre custos, tempo de execução das atividades e complexidade. Tais dados compreendem o atendimento de pedidos e o faturamento (em peso e valor) dos itens de cada processo. Como demonstrados nas Tabelas 12 e 13. Novamente, lembre-se que todos os dados aqui publicados obedecem às políticas confidenciosas da empresa analisada. E ressaltese que os gráficos sofreram translações para melhor visualização. 
Tabela 12 : Atendimento de pedidos

\begin{tabular}{|c|c|c|c|c|c|c|c|c|c|c|c|c|c|}
\hline & & Janeiro & Fevereiro & Março & Abril & Maio & Junho & Julho & Agosto & Setembro & Outubro & Novembro & Dezembro \\
\hline \multicolumn{2}{|l|}{$\mathrm{N}^{\circ}$ de pedidos } & 17214 & 14238 & 19664 & 17224 & 23152 & 22040 & 25002 & 23490 & 25336 & 29150 & 18702 & 2712 \\
\hline \multicolumn{2}{|l|}{$\mathrm{N}^{\circ}$ de pré-notas } & 19426 & 26384 & 27750 & 29048 & 33466 & 34724 & 32460 & 40082 & 39884 & 36902 & 37732 & 40672 \\
\hline \multicolumn{2}{|l|}{$\mathrm{N}^{\mathrm{o}}$ de carregamentos } & 2642 & 2334 & 2894 & 2802 & 2936 & 2914 & 3324 & 3394 & 3042 & 3178 & 3154 & 3778 \\
\hline \multirow{6}{*}{$\begin{array}{l}\text { Tempo de ciclo } \\
\text { (dias) }\end{array}$} & Acoll & 0,44 & 1,02 & 0,82 & 1,06 & 0,84 & 0,9 & 0,76 & 0,74 & 0,76 & 0,74 & 0,82 & 0,7 \\
\hline & Aprov & 0,34 & 0,4 & 0,42 & 0,54 & 0,54 & 0,4 & 0,5 & 0,5 & 0,44 & 0,48 & 0,34 & 0,48 \\
\hline & Faturamento & 4,04 & 4,18 & 3,34 & 3,44 & 4,24 & 3,38 & 2,9 & 2,84 & 2,6 & 2,8 & 2,68 & 2,98 \\
\hline & Carregamento & 7,1 & 6,34 & 6,42 & 5,36 & 6,02 & 6,12 & 5,02 & 3,54 & 4 & 4,54 & 5,46 & 4,48 \\
\hline & ssporte & 6,2 & 7,18 & 6,46 & 5,48 & 8,36 & 5,44 & 5,54 & 5,62 & 5,76 & 5,96 & 6,28 & 5,92 \\
\hline & Ciclo total & 18,12 & 19,24 & 17,46 & 15,88 & 20,02 & 16,26 & 14,76 & 13,24 & 13,56 & 14,48 & 15,58 & 14,54 \\
\hline
\end{tabular}
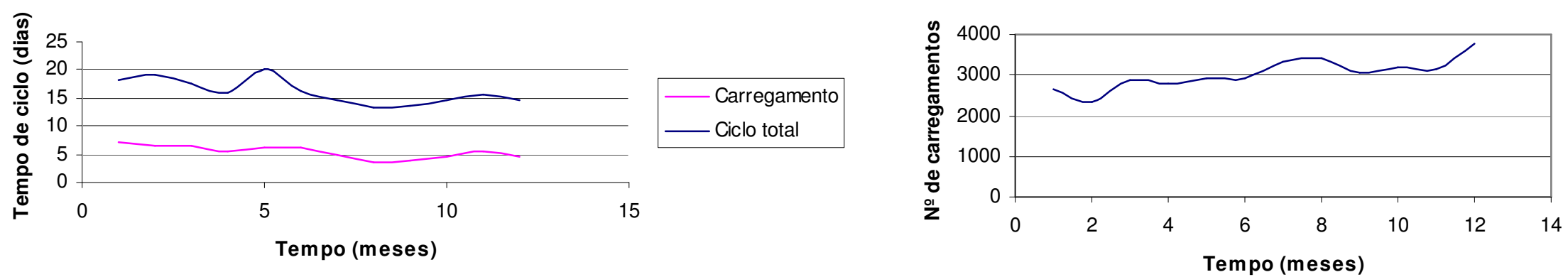

Figura 64 : Gráficos sobre tempo de ciclo e $n^{\circ}$ de carregamentos 
Tabela 13 : Faturamento de 2005

\begin{tabular}{|c|c|c|c|c|c|c|c|c|c|c|c|c|c|c|c|}
\hline & & \multicolumn{2}{|c|}{ Janeiro } & \multicolumn{2}{|c|}{ Fevereiro } & \multicolumn{2}{|c|}{ Março } & \multicolumn{2}{|c|}{ Abril } & \multicolumn{2}{|c|}{ Maio } & \multicolumn{2}{|c|}{ Junho } & \multicolumn{2}{|c|}{ Julho } \\
\hline \multirow[t]{2}{*}{ Faturamento } & $\begin{array}{l}(\mathrm{R} \$) \\
(\mathrm{Kg})\end{array}$ & \multicolumn{2}{|c|}{$\begin{array}{c}146564210 \\
15374740\end{array}$} & \multicolumn{2}{|c|}{$\begin{array}{c}208710264 \\
23064990\end{array}$} & \multicolumn{2}{|c|}{$\begin{array}{c}224747104 \\
24635848\end{array}$} & \multicolumn{2}{|c|}{$\begin{array}{c}209507198 \\
22549176\end{array}$} & \multicolumn{2}{|c|}{$\begin{array}{c}223323120 \\
24734568\end{array}$} & \multicolumn{2}{|c|}{$\begin{array}{c}248119000 \\
28012326\end{array}$} & \multicolumn{2}{|c|}{$\begin{array}{c}195721606 \\
23487856\end{array}$} \\
\hline & & Peso (\%) & Valor (\%) & Peso (\%) & Valor (\%) & Peso (\%) & Valor (\%) & Peso (\%) & Valor (\%) & Peso (\%) & Valor (\%) & Peso (\%) & Valor (\%) & Peso (\%) & Valor (\%) \\
\hline Extrusão & & 72,99 & 50,74 & 75,11 & 52,83 & 76 & 53,85 & 74,9 & 52,9 & 76,74 & 54,38 & 76,25 & 53,71 & 77,26 & 54,64 \\
\hline Injeção & & 16,51 & 34,88 & 14,97 & 33,46 & 15,65 & 34,2 & 15,34 & 33,4 & 13,8 & 32,35 & 14,89 & 33,85 & 14,08 & 33 \\
\hline Revestimento & & 0,68 & 2,46 & 0,78 & 2,41 & 0,74 & 2,38 & 0,37 & 1,79 & 0,39 & 1,96 & 0,32 & 1,62 & 0,28 & 1,46 \\
\hline Outros & & 8,69 & 10,43 & 7,92 & 9,71 & 6,41 & 7,99 & 8,2 & 10,33 & 8,05 & 9,91 & 7,43 & 9,46 & 7,42 & 9,33 \\
\hline Sopro & & 1,14 & 1,49 & 1,23 & 1,59 & 1,19 & 1,58 & 1,2 & 1,58 & 1,01 & 1,4 & 1,1 & 1,66 & 0,96 & 1,56 \\
\hline
\end{tabular}

\begin{tabular}{ccccccc}
\hline & & Agosto & Setembro & Outubro & Novembro & Dezembro \\
\hline \multirow{4}{*}{ Faturamento } & & & & & & \\
& & & & & & \\
& $(\mathrm{Kg})$ & 241265396 & 235966824 & 225228220 & 241104256 & 268235686 \\
& & 27388158 & 28206800 & 27776972 & 29019080 & 31695846
\end{tabular}

Peso (\%) Valor(\%) Peso (\%) Valor(\%) Peso (\%) Valor(\%) $\quad$ Peso (\%) Valor(\%) $\quad$ Peso (\%) $\quad$ Valor $(\%)$

\begin{tabular}{lrrrrrrrrrr} 
Extrusão & 73,88 & 51,52 & 75,15 & 52,9 & 76,68 & 55,12 & 74,86 & 52,46 & 75,12 & 51,44 \\
Injeção & 15,65 & 35,11 & 14,88 & 33,83 & 14,46 & 32,48 & 14,92 & 34,16 & 14,94 & 34,8 \\
Revestimento & 0,31 & 1,42 & 0,31 & 1,49 & 0,26 & 1,28 & 0,31 & 1,52 & 0,32 & 1,52 \\
Outros & 9 & 10,24 & 8,57 & 10,05 & 7,6 & 9,52 & 8,72 & 10,01 & 8,37 & 10,31 \\
Sopro & 1,17 & 1,71 & 1,1 & 1,73 & 1,01 & 1,6 & 1,19 & 1,85 & 1,25 & 1,93 \\
\hline
\end{tabular}


Inicialmente, será conduzida uma análise de séries temporais, diretamente análoga a análises de série temporais de experimentos e quase-experimentos. A lógica essencial subjacente a um projeto de série temporal é a comparação entre uma tendência de dados comparada a (a) uma tendência teórica significante, especificada antes do começo da investigação, com (b) alguma tendência rival, também especificada anteriormente e com (c) qualquer tendência baseada em algum artefato ou ameaça à validade interna.

Pode-se dizer que o processo principal da unidade pesquisada é a extrusão, como mostra a Tabela 13. Graficamente, pode-se ver a participação desse processo na logística pela Figura 65.

Extrusão ( $\%$ de faturamento em $\mathrm{Kg}$ )

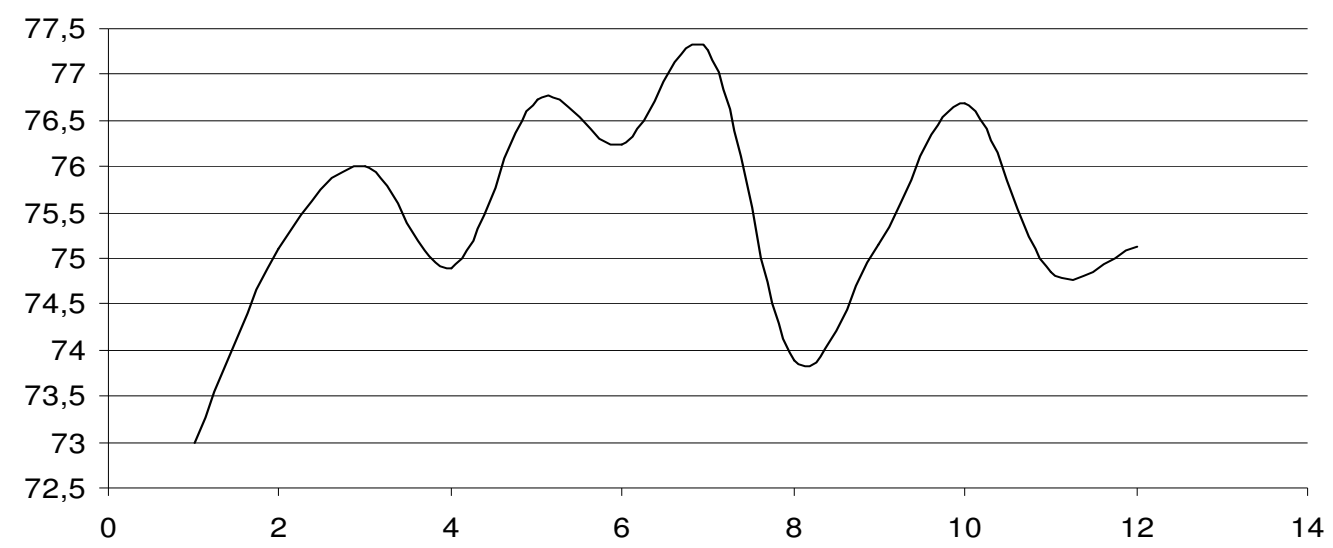

Figura 65 : Participação do processo de extrusão no faturamento $(\mathrm{Kg})$ do ano de 2005

Pode-se inferir que o mês de agosto possui menor vendagem de produtos da extrusão, e que o tempo de ciclo nesse mês possui pequena diminuição. Os carregamentos aumentaram, demonstrando a participação de outros processos no faturamento, em especial, o processo de injeção. Como demonstra a Figura 66, abaixo.

Injeção (\% em Kg)

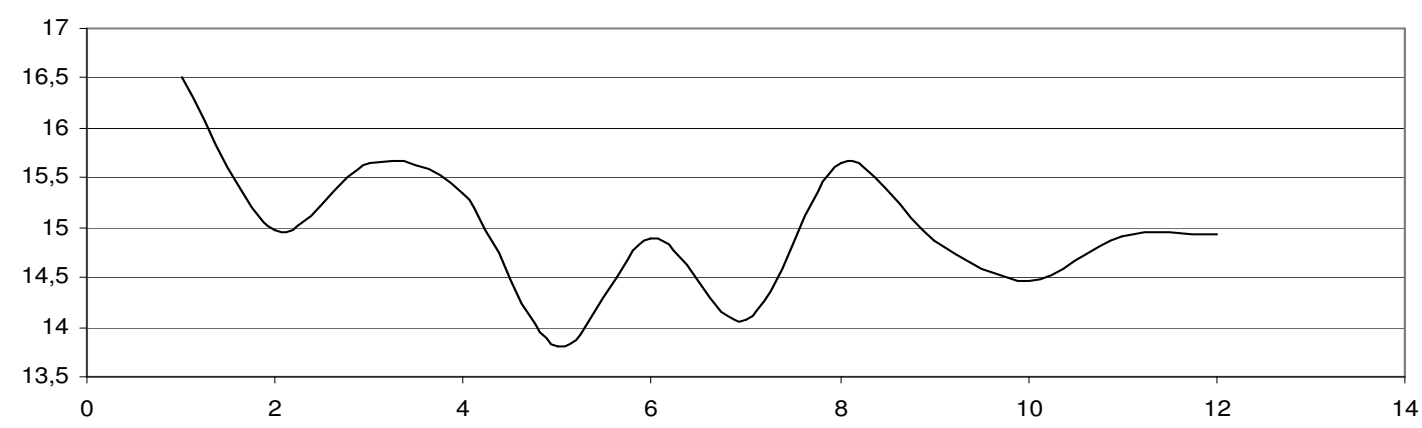

Figura 66 : Participação do processo de injeção no faturamento (Kg) do ano de 2005 
Tais gráficos sugerem que o tempo de ciclo possui maior correlação com o faturamento de itens do processo de extrusão, sendo o mês de março o mais custoso, mormente devido à conta de materiais diretos. E seguida, novembro devido à conta salários e encargos. A Figura 67 ilustra os custos logísticos totais da unidade analisada.

Custos toais

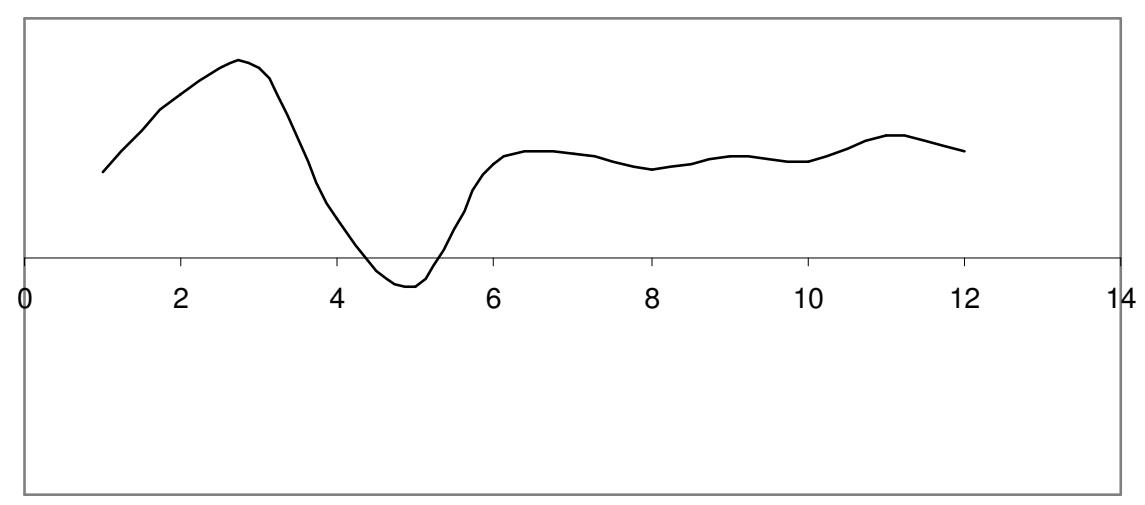

Figura 67 : Custos totais da unidade de análise

A atividade mais complexa, separação (separar, embalar e emitir etiqueta), teve como maior fator de custo, as pessoas. Conta cujos meses mais custosos foram novembro e dezembro, justamente quando ocorre um aumento no faturamento de itens do processo de injeção, principais responsáveis pela complexidade. Paralelamente, pode-se constatar aumento no tempo de atendimento, também, em novembro.

Olhando-se o custo dessa atividade, ao longo do período analisado, pode-se constatar que em março ocorreu o maior consumo de recursos, principalmente devido à conta material de consumo. Justamente o período de aumento de faturamento de itens do processo de injeção, como se pode verificar na Tabela 14. 
Tabela 14 : Custos mensais da atividade de separação

\begin{tabular}{|c|c|c|c|c|c|c|c|c|c|c|c|c|}
\hline & Janeiro & Fevereiro & Março & Abril & Maio & Junho & Julho & Agosto & Setembro & Outubro & Novembro & Dezembro \\
\hline \multicolumn{13}{|l|}{ Pessoas } \\
\hline Salários e encargos & 6787,875 & 6042,112 & 6798,193 & 6992,316 & 6788,261 & 7233,32301 & 7639,572 & 7097,134 & 7799,06 & 7949,089 & 9305,85652 & 8802,474819 \\
\hline Alimentos, ingredientes & 348,3156 & 383,6223 & 153,1484 & 644,8375 & 456,3824 & 415,980797 & 405,29 & 390,1484 & 436,3462 & 441,0261 & 428,560688 & 523,2032609 \\
\hline Assistência educacional & 17,31703 & 11,49221 & 19,20616 & 18,47627 & 18,47627 & 18,4762681 & 19,80725 & 17,94674 & 21,33859 & 18,54783 & 21,338587 & 15,61394928 \\
\hline Assistência médica & 509,0491 & 897,5373 & 567,5549 & 522,4018 & 629,4955 & 617,158877 & 1688,382 & 598,0243 & 1560,279 & 652,4083 & 652,952174 & 780,3110507 \\
\hline Cantina & 14,52627 & 14,18279 & 51,42156 & 52,00833 & 19,56395 & 17,0451087 & 20,45127 & 43,26395 & 39,31395 & 44,52337 & 33,3030797 & 27,99347826 \\
\hline Contrib. Assist. social & 43,66467 & 9,917935 & 49,48949 & 46,82754 & 9,202355 & 80,9606884 & 61,66866 & 67,98007 & 34,27627 & 94,52808 & 64,6884058 & 10,00380435 \\
\hline Contribuições, Donativos & 0,157428 & 0,100181 & 0 & 0 & 0,014312 & 0 & 0,057246 & 0,186051 & 0,128804 & 0,028623 & 1,03043478 & 2,79076087 \\
\hline Previdência privada & 1,302355 & 1,302355 & 1,302355 & 1,302355 & 1,302355 & 1,30235507 & 1,302355 & 1,302355 & 1,302355 & 1,302355 & 1,30235507 & 5,238043478 \\
\hline Refeição Pronta & 0 & 0 & 0 & 0 & 0 & 0 & 1,545652 & 8,758696 & 0 & 0 & 0 & 0 \\
\hline Treina & 0 & 0 & 2,475906 & 0 & 0 & 0 & 0 & 12,39384 & 8,071739 & 9,087862 & 17,9896739 & 13,62463768 \\
\hline Assistência Técnica e adm. & 66,84946 & 37,08134 & 159,8891 & 251,1399 & 249,7803 & 244,942935 & 275,4123 & 282,4536 & 111,9453 & 43,93659 & 38,2692029 & 146,5650362 \\
\hline Outros PA' & 154,9803 & 154,2647 & 171,4386 & 170,3795 & 167,2739 & 151,316486 & 147,3522 & 149,4274 & 146,5221 & 140,3824 & 141,140942 & 143,9030797 \\
\hline Assinaturas,mensalidades & 0 & 0 & 3,749638 & 0 & 0 & 0 & 0 & 0 & 3,749638 & 0 & 0 & 0 \\
\hline Total pessoas & 7944,037 & 7551,613 & 7977,869 & 8699,689 & 8339,752 & 8780,50652 & 10260,84 & 8669,019 & 10162,33 & 9394,86 & 10706,4321 & 10471,72192 \\
\hline
\end{tabular}

Recursos armazém

\begin{tabular}{|c|c|c|c|c|c|c|c|c|c|c|c|c|}
\hline Água & 1,087681 & 1,087681 & 4,951812 & 1,087681 & 1,25942 & 1,31666667 & 0,844384 & 1,674457 & 0,844384 & 1,25942 & 2,97681159 & 1,25942029 \\
\hline Comunicações & 97,43333 & 63,78678 & 63,92989 & 61,61141 & 100,8824 & 105,075725 & 62,24112 & 63,04257 & 110,2565 & 63,40036 & 70,8853261 & 68,75289855 \\
\hline Condução & 0,083007 & 0,403587 & 0,128804 & 0,080145 & 0 & 0,14884059 & 1,070507 & 0,171739 & 0,145978 & 0,214674 & 0,99608701 & 0,784275406 \\
\hline Energia elétrica & 14,774 & 20,538 & 21,188 & 20,926 & 19,524 & 18,022 & 19,098 & 21,278 & 25,042 & 29,4 & 28,098 & 26,848 \\
\hline Equipa. Prot. Individual & 17,4029 & 23,51395 & 29,41033 & 14,99855 & 17,44583 & 14,1398551 & 14,32591 & 19,90743 & 27,57844 & 23,39946 & 19,9074275 & 23,35652174 \\
\hline Material de consumo & 262,5599 & 19561,76 & 25556,71 & $-10902,9$ & $-27439,5$ & 1704,63497 & 278,7053 & 431,7508 & 153,0455 & 461,4069 & 4492,50107 & $-696,3848974$ \\
\hline Material de expediente & 197,4174 & $-87,2583$ & 31,89849 & 23,15303 & 48,80076 & 48,4083367 & 47,67955 & 35,15 & 51,8 & 13,20227 & 25,9000018 & 46,58636691 \\
\hline Uniformes & 10,01812 & 10,91975 & 29,3817 & 19,46377 & 16,68732 & 14,9842391 & 15,4279 & 17,63188 & 18,74819 & 21,75362 & 18,9056159 & 17,57463768 \\
\hline Processamento de dados & 235,7068 & 184,1871 & 272,2023 & 266,7084 & 193,4091 & 18,2196983 & 388,1917 & 375,8584 & 471,0493 & 421,5197 & 264,578049 & 320,7507801 \\
\hline Total armazém & 836,4832 & 19778,94 & 26009,81 & $-10494,9$ & $-27041,5$ & 1924,95033 & 827,5844 & 966,4652 & 858,5103 & 1035,556 & 4924,74839 & $-190,4719967$ \\
\hline
\end{tabular}

\begin{tabular}{|c|c|c|c|c|c|c|c|c|c|c|c|c|}
\hline Material de embalagem & 14,88 & 59,34 & 0 & 136,98 & 220,38 & 0 & 0 & 5,48 & 15,22 & 0 & 15,18 & 109,74 \\
\hline Total & 8795,4 & 27389,89 & 33987,68 & $-1658,25$ & $-18481,3$ & 10705,4569 & 11088,42 & 9640,964 & 11036,06 & 10430,42 & 15646,3605 & 10390,98992 \\
\hline
\end{tabular}


Conferir manifesto, indicar local e contar

\begin{tabular}{|c|c|c|c|c|c|c|c|c|c|c|c|c|}
\hline \multicolumn{13}{|c|}{ Conferir manifesto, indicar local e contar } \\
\hline & Janeiro & Fevereiro & Março & Abril & Maio & Junho & Julho & Agosto & Setembro & Outubro & Novembro & Dezembro \\
\hline \multicolumn{13}{|l|}{ Pessoas } \\
\hline Salários e encargos & 1288,837 & 1147,236 & 1290,796 & 1327,654987 & 1288,91 & 1373,41586 & 1450,552 & 1347,557 & 1480,834 & 1509,321 & 1766,93491 & 1671,356099 \\
\hline Alimentos, ingredientes & 66,13587 & 72,83968 & 29,07881 & 122,4375088 & 86,6549 & 78,9837013 & 76,95381 & 74,07881 & 82,85055 & 83,73914 & 81,3722885 & 99,34239846 \\
\hline Assistência educacional & 3,288044 & 2,182065 & 3,646739 & 3,508152427 & 3,508152 & 3,50815243 & 3,76087 & 3,407609 & 4,051631 & 3,521739 & 4,05163073 & 2,964674127 \\
\hline Assistência médica & 96,6549 & 170,4185 & 107,7636 & 99,19022453 & 119,5245 & 117,182074 & 320,5788 & 113,5489 & 296,2555 & 123,875 & 123,97827 & 148,1603368 \\
\hline Cantina & 2,758152 & 2,692935 & 9,763588 & 9,875000711 & 3,714674 & 3,23641328 & 3,883152 & 8,214675 & 7,464674 & 8,453805 & 6,32337002 & 5,315217774 \\
\hline Contrib. Assist. social & 8,290761 & 1,883152 & 9,39674 & 8,891304988 & 1,747283 & 15,3722837 & 11,70924 & 12,90761 & 6,508153 & 17,94837 & 12,2826096 & 1,899456659 \\
\hline Contribuições, Donativos & 0,029891 & 0,019022 & 0 & 0 & 0,002717 & 0 & 0,01087 & 0,035326 & 0,024457 & 0,005435 & 0,19565219 & 0,529891343 \\
\hline Previdência privada & 0,247283 & 0,247283 & 0,247283 & 0,247282627 & 0,247283 & 0,24728263 & 0,247283 & 0,247283 & 0,247283 & 0,247283 & 0,24728263 & 0,994565289 \\
\hline Refeição Pronta & 0 & 0 & 0 & 0 & 0 & 0 & 0,293478 & 1,663044 & 0 & 0 & 0 & 0 \\
\hline Treinamento & 0 & 0 & 0,470109 & 0 & 0 & 0 & 0 & 2,353261 & 1,532609 & 1,725544 & 3,41576112 & 2,586956708 \\
\hline Assistência Técnica e adm. & 12,69294 & 7,040761 & 30,3587 & 47,68478604 & 47,42663 & 46,5081555 & 52,29348 & 53,63044 & 21,25544 & 8,342392 & 7,26630487 & 27,82880635 \\
\hline Outros PA' & 29,42663 & 29,29076 & 32,55163 & 32,35054581 & 31,76087 & 28,7309803 & 27,97826 & 28,37228 & 27,82065 & 26,65489 & 26,798915 & 27,32337153 \\
\hline Assinaturas,mensalidades & 0 & 0 & 0,711957 & 0 & 0 & 0 & 0 & 0 & 0,711957 & 0 & 0 & 0 \\
\hline Total pessoas & 1508,362 & 1433,851 & 1514,785 & 1651,839793 & 1583,497 & 1667,1849 & 1948,261 & 1646,016 & 1929,557 & 1783,834 & 2032,86699 & 1988,301774 \\
\hline \multicolumn{13}{|l|}{ Recursos armazém } \\
\hline Água & 0,206522 & 0,206522 & 0,940217 & 0,206521754 & 0,23913 & 0,25000002 & 0,160326 & 0,317935 & 0,160326 & 0,23913 & 0,56521743 & 0,239130452 \\
\hline Comunicações & 18,5 & 12,11141 & 12,13859 & 11,69837041 & 19,15489 & 19,9510884 & 11,81794 & 11,97011 & 20,93478 & 12,03804 & 13,4592401 & 13,05434877 \\
\hline Condução & 0,015761 & 0,07663 & 0,024457 & 0,015217398 & 0 & 0,02826088 & 0,203261 & 0,032609 & 0,027717 & 0,040761 & 0,18913052 & 0,148913109 \\
\hline Equipa. Prot. Individual & 0,66087 & 0,892935 & 1,116848 & 0,569565468 & 0,6625 & 0,53695676 & 0,544022 & 0,755979 & 1,047283 & 0,888587 & 0,75597859 & 0,886956912 \\
\hline Uniformes & 0,380435 & 0,414674 & 1,115761 & 0,73913076 & 0,633696 & 0,56902199 & 0,58587 & 0,669566 & 0,711957 & 0,826087 & 0,7179351 & 0,667391598 \\
\hline Total armazém & 19,76359 & 13,70218 & 15,33587 & 13,22880579 & 20,69022 & 21,335328 & 13,31141 & 13,7462 & 22,88207 & 14,03261 & 15,6875017 & 14,99674084 \\
\hline Total & 1528,125 & 1447,553 & 1530,121 & 1665,068599 & 1604,188 & 1688,52023 & 1961,572 & 1659,763 & 1952,439 & 1797,867 & 2048,5545 & 2003,298514 \\
\hline Total para movimentar tubos & 4732,052 & 4264,16 & 4570,42 & 5015,895408 & 5172,507 & 5129,0844 & 5460,875 & 5098,134 & 5776,931 & 5493,977 & 6023,51021 & 6184,587711 \\
\hline
\end{tabular}


Contrastando-se as curvas de faturamento em quilos do processo de injeção, principal responsável pela complexidade na atividade de separação, e a curva dos custos de separação, Figura 68, pode-se perceber que entre os meses de julho e agosto, e novembro e dezembro, apesar do aumento de faturamento dos itens de injeção, os custos de separação foram decrescentes. Ora, espera-se que, com o aumento da complexidade, aumentem-se os custos. Evidência que corrobora a revisão e reforça a validade interna desse trabalho.

Ou seja, ocorreu um erro no custeio baseado em atividades para atividade de separação, decorrente do aumento da complexidade, sem correspondente aumento nos custos de separação.

Complexidade vrs custos

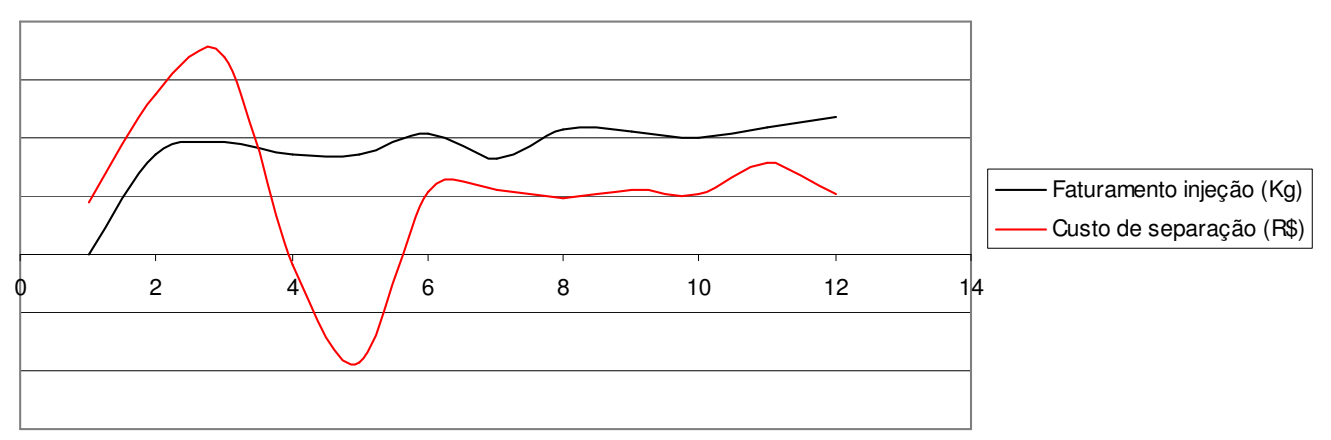

Figura 68 : Complexidade versus custos de separação

Do mesmo modo, espera-se que, com o aumento do tempo de atendimento do pedido, representado pelo tempo de carregamento, aumentem-se os custos correlatos. Porém, como demonstra a Figura 69, entre os meses de setembro e outubro o tempo de carregamento aumentou e os custos de carregamento diminuíram, como demonstra a Tabela 15. Tais evidências demonstram incoerência entre o esperado e o acontecido, indicando falha no custeio.

Assaz comentário deve ser feito em relação aos custos de carregamento, estes são compostos pelos custos das atividades de conferir manifesto/indicar local/contar e informar local/conferir manifesto/emitir nota fiscal. 
Tabela 15 : Custos mensais da atividade de carregamento

\begin{tabular}{|c|c|c|c|c|c|c|c|c|c|c|c|c|}
\hline \multicolumn{13}{|l|}{ Continuação } \\
\hline \multicolumn{13}{|c|}{ Informar local, conferir manifesto e emitir nota } \\
\hline & Janeiro & Fevereiro & Março & Abril & Maio & Junho & Julho & Agosto & Setembro & Outubro & Novembro & Dezembro \\
\hline \multicolumn{13}{|l|}{ Pessoas } \\
\hline Salários e encargos & 1031,07 & 917,7891 & 1032,637 & 1062,123892 & 1031,128 & 1098,73259 & 1160,441 & 1078,046 & 1184,667 & 1207,456 & 1413,5478 & 1337,084756 \\
\hline Alimentos, ingredientes & 52,90869 & 58,27174 & 23,26304 & 97,94999804 & 69,32391 & 63,1869553 & 61,56304 & 59,26304 & 66,28043 & 66,9913 & 65,0978248 & 79,47391145 \\
\hline Assistência educacional & 2,630435 & 1,745652 & 2,917391 & 2,806521683 & 2,806522 & 2,80652168 & 3,008696 & 2,726087 & 3,241304 & 2,817391 & 3,24130428 & 2,371739083 \\
\hline Assistência médica & 77,32391 & 136,3348 & 86,21087 & 79,35217233 & 95,61956 & 93,7456503 & 256,463 & 90,83913 & 237,0043 & 99,1 & 99,1826067 & 118,5282585 \\
\hline Cantina & 2,206522 & 2,154348 & 7,810869 & 7,899999842 & 2,971739 & 2,58913038 & 3,106522 & 6,571739 & 5,971739 & 6,763043 & 5,05869555 & 4,252173828 \\
\hline Contrib. Assist. social & 6,632609 & 1,506522 & 7,517391 & 7,113043336 & 1,397826 & 12,2978258 & 9,367391 & 10,32609 & 5,206522 & 14,3587 & 9,82608676 & 1,519565187 \\
\hline Contribuições, Donativos & 0,023913 & 0,015217 & 0 & 0 & 0,002174 & 0 & 0,008696 & 0,028261 & 0,019565 & 0,004348 & 0,15652174 & 0,423913035 \\
\hline Previdência privada & 0,197826 & 0,197826 & 0,197826 & 0,197826083 & 0,197826 & 0,19782608 & 0,197826 & 0,197826 & 0,197826 & 0,197826 & 0,19782608 & 0,795652158 \\
\hline Refeição Pronta & 0 & 0 & 0 & 0 & 0 & 0 & 0,234783 & 1,330435 & 0 & 0 & 0 & 0 \\
\hline Treinamento & 0 & 0 & 0,376087 & 0 & 0 & 0 & 0 & 1,882609 & 1,226087 & 1,380435 & 2,73260864 & 2,069565176 \\
\hline Assistência Técnica e adm. & 10,15435 & 5,632609 & 24,28696 & 38,14782532 & 37,9413 & 37,206521 & 41,83478 & 42,90435 & 17,00435 & 6,673913 & 5,81304336 & 22,26304303 \\
\hline Outros PA' & 23,5413 & 23,43261 & 26,0413 & 25,88043427 & 25,4087 & 22,9847821 & 22,38261 & 22,69783 & 22,25652 & 21,32391 & 21,43913 & 21,85869522 \\
\hline Assinaturas,mensalidades & 0 & 0 & 0,569565 & 0 & 0 & 0 & 0 & 0 & 0,569565 & 0 & 0 & 0 \\
\hline Total pessoas & 1206,689 & 1147,08 & 1211,828 & 1321,471713 & 1266,798 & 1333,7478 & 1558,609 & 1316,813 & 1543,646 & 1427,067 & 1626,29345 & 1590,641273 \\
\hline \multicolumn{13}{|l|}{ Recursos armazém } \\
\hline Água & 0,165217 & 0,165217 & 0,752174 & 0,165217388 & 0,191304 & 0,2 & 0,128261 & 0,254348 & 0,128261 & 0,191304 & 0,4521739 & 0,191304344 \\
\hline Comunicações & 14,8 & 9,68913 & 9,710869 & 9,358695465 & 15,32391 & 15,9608692 & 9,454348 & 9,576087 & 16,74783 & 9,630435 & 10,7673911 & 10,44347805 \\
\hline Condução & 0,012609 & 0,061304 & 0,019565 & 0,012173913 & 0 & 0,0226087 & 0,162609 & 0,026087 & 0,022174 & 0,032609 & 0,15130434 & 0,119130432 \\
\hline Energia elétrica & 14,774 & 20,538 & 21,188 & 20,926 & 19,524 & 18,022 & 19,098 & 21,278 & 25,042 & 29,4 & 28,098 & 26,848 \\
\hline Equipa. Prot. Individual & 2,643478 & 3,571739 & 4,467391 & 2,278260824 & 2,65 & 2,14782604 & 2,176087 & 3,023913 & 4,18913 & 3,554348 & 3,02391298 & 3,547826016 \\
\hline Material de consumo & 49,67348 & 3700,873 & 4835,054 & $-2062,719696$ & $-5191,25$ & 322,498485 & 52,72803 & 81,68258 & 28,95455 & 87,29318 & 849,932575 & $-131,7484848$ \\
\hline Material de expediente & 37,34924 & $-16,5083$ & 6,034848 & 4,380303028 & 9,232576 & 9,15833333 & 9,020455 & 6,65 & 9,8 & 2,497727 & 4,9 & 8,813636359 \\
\hline Uniformes & 1,521739 & 1,658696 & 4,463043 & 2,95652168 & 2,534783 & 2,27608691 & 2,343478 & 2,678261 & 2,847826 & 3,304348 & 2,87173907 & 2,669565164 \\
\hline Processamento de dados & 44,59318 & 34,84621 & 51,49773 & 50,4583333 & 36,59091 & 3,4469697 & 73,44167 & 71,10833 & 89,11742 & 79,74697 & 50,055303 & 60,68257572 \\
\hline Total armazém & 165,533 & 3754,895 & 4933,187 & $-1972,18419$ & $-5105,21$ & 373,733179 & 168,5529 & 196,2776 & 176,8492 & 215,6509 & 950,2524 & $-18,43296868$ \\
\hline Total & 1372,222 & 4901,976 & 6145,016 & $-650,7124775$ & $-3838,41$ & 1707,48098 & 1727,162 & 1513,091 & 1720,495 & 1642,718 & 2576,54585 & 1572,208304 \\
\hline Custos de carregamento & 2900,347 & 6349,529 & 7675,137 & 1014,356121 & $-2234,22$ & 3396,00121 & 3688,734 & 3172,853 & 3672,934 & 3440,585 & 4625,10034 & 3575,506818 \\
\hline
\end{tabular}


Tempo vrs custos
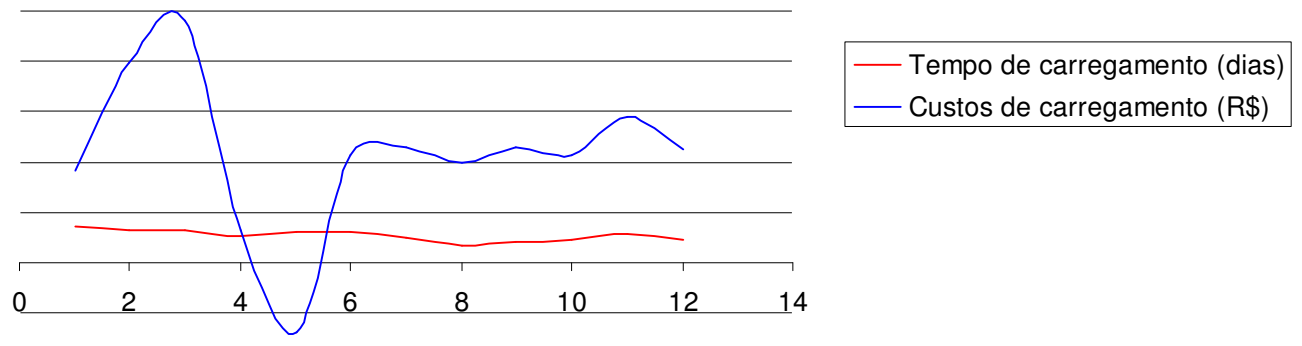

Figura 69 : Tempo versus custos de carregamento

Continuando as considerações, será feita uma análise de adequação ao padrão por meio de explicações rivais. Esta análise exige o desenvolvimento de proposições teóricas rivais, articuladas em termos operacionais. A característica importante destas explicações rivais é que cada uma envolve padrões de variáveis independentes mutuamente exclusivos. Desse modo, a presença de certas variáveis independentes (previstas por uma explicação) impede a presença de outras variáveis (previstas por uma explicação rival). As variáveis independentes podem envolver alguns ou muitos tipos diferentes de características ou eventos, com cada um avaliado por diferentes medidas e instrumentos. O interesse da análise do estudo de caso, de qualquer modo, é com o padrão geral dos resultados e o grau com que o padrão se iguala ao previsto.

$\mathrm{O}$ que se afirmou anteriormente foi que ocorreu um aumento na complexidade, sem correspondente aumento nos custos; a explicação para isso seria um aumento no faturamento de itens de injeção, porém com cada pedido possuindo pouca variedade de itens. Tal fato, de acordo com gerente responsável pela logística de distribuição, não ocorreu. Uma explicação alternativa dada baseou-se na quantidade do estoque de itens de injeção, que apresentou baixa durante os meses de julho e agosto, e novembro e dezembro. Como demonstra a Figura 70.

Outra explicação seria a diminuição do número de pré-notas, hipótese excluída como demonstra a Tabela 12, já que ocorreu aumento nos referidos períodos. Portanto, derrubadas as ameaças à hipótese inicial, têm-se fortes indícios de que o método de custeio implantado produziu informações errôneas, em relação aos custos das atividades. 


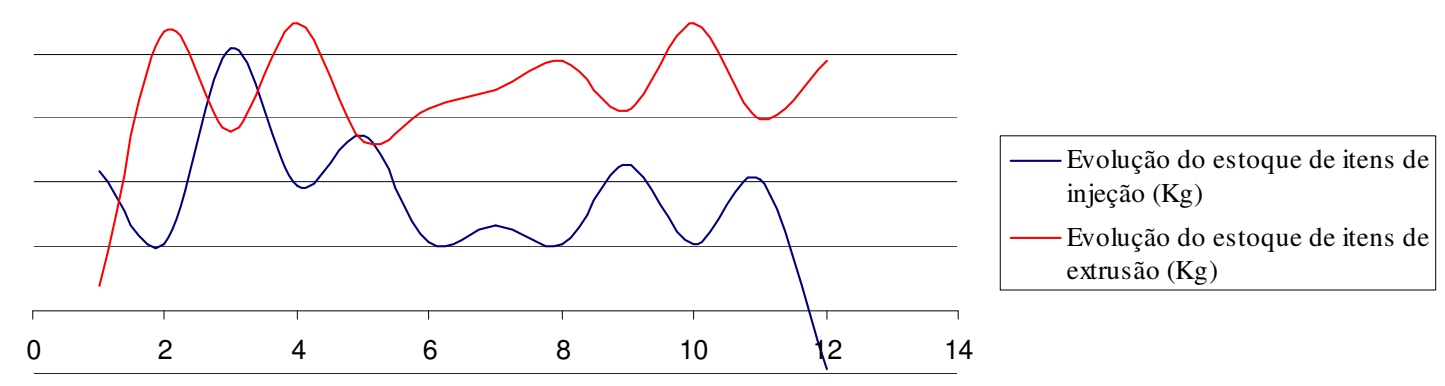

Figura 70 : Evolução do estoque em 2005

Paralelamente, se afirmou que, com o aumento do tempo de atendimento do pedido, principalmente representado pelo tempo de carregamento, aumentem-se os custos correlatos. Isto não ocorreria caso houvesse diminuição dos carregamentos, e, simultaneamente, aumento do volume faturado de itens de extrusão, entre setembro e outubro, o que de fato, foi o que não ocorreu como demonstram as Tabela 12 e 13. Portanto, novamente, consolida-se a hipótese defendida neste trabalho.

No intuito de ampliar a análise dos dados coletados durante o estudo será realizado um construto explicativo para de solucionar a questão principal.

Como visto pela Figura 61, para separar os itens de uma pré-nota, despende-se em torno de dois minutos, porém esse número pode variar consideravelmente de acordo com o observado in loco. Algumas pré-notas podem demorar até um turno para ser separadas. E o principal motivo para esse fato é a variedade de itens que devem ser manuseados.

Em relação ao tempo, afirma-se que as principais influências provêm das atividades de colacionar, durante o carregamento, ou seja, comparar o que é pedido no manifesto e o que é carregado. Ressaltem-se os itens derivados do processo de extrusão, que passam por três conferências. Em especial, a última conferência do carregamento de pátio requer quinze minutos por caminhão!

Em contraste, o método de custeio baseado em atividades se utiliza de uma base fixa para alocar custos diretos e indiretos às atividades; assim, o custo para separar um pedido que demorou oito horas é o mesmo de outro cujo tempo dispensado foi de dois minutos. Claramente, incorre-se um erro, cujo sintoma é o tempo e a causa 
complexidade. Logo, para custear corretamente as atividades deve-se tratar com siso a medição do tempo.

Kaplan e Anderson (2003) sugerem tratar a capacidade real de um processo como oitenta por cento $(80 \%)$ da máxima, obtida pela análise de série temporal e eleita com crivo de alguns fatores subjetivos (ausência de qualidade pobre e empregados estressados). Com a capacidade e o tempo de cada atividade pode-se estimar seus custos. Adicionalmente, sugerem cercar o problema de medição do tempo real pela criação de fórmulas de tempo para cada atividade. Kulmala, Paranko e Yrjänänen (2000) propõem que sejam criadas categorias de atividades de acordo o tempo que utilizam determinado recurso. Cada produto faria parte de uma estrutura de custos, e seria alocado em uma categoria (os autores propõem quatro: itens de volume, itens baseados em prognósticos, itens baseados em ordens e itens estratégicos).

Por outro lado, Womack e Jones (2004) estendendo o pensamento enxuto para a cadeia de suprimentos, priorizam a máxima diminuição de desperdícios; por consequiência, imperam a diminuição do tempo que não agrega valor. Em sua proposta, tem-se a aproximação dos elos da cadeia (lembre-se que o ponto final de seu estudo é um centro de distribuição) de tal modo que apenas uma pessoa seria responsável pelo transporte inter-fábricas de pequenos lotes para atender kanbans eletrônicos transeuntes num condomínio industrial. Os autores sugerem que depois de enxutos os elos devem se aproximar e concentrar as atividades.

De fato, no estudo de caso, pode-se notar a ocorrência de vários estoques intermediários, principalmente, em relação aos itens resultantes do processo de injeção. Estes esperam numa doca de saída da produção para ser transportados até local de conferência e acolhimento, para, depois, ser transportados ao armazém, onde podem abastecer o estoque ou prateleiras de separação. Além disso, constata-se a presença de várias atividades demoradas e que não agregam valor, especialmente as já citadas atividades de colacionar.

Desse modo, a literatura aponta para um tipo de custeio que diferencie o desempenho de cada elo, e para isso é fundamental a rastreabilidade dos produtos ao longo da cadeia. De encontro a esta necessidade surge uma tecnologia, a identificação por rádio frequiência.

Tal tecnologia baseia-se em pequenos transponders RFID ou tags que contêm um identificador único, e são empregados em paletes, embalagens ou itens individuais 
que se comunicam com os leitores RFID. Esses leitores associam o identificador único com informação sobre o produto ao qual o tag está fixado. Sua aplicação na cadeia de suprimentos é demonstrada pela Figura 71.

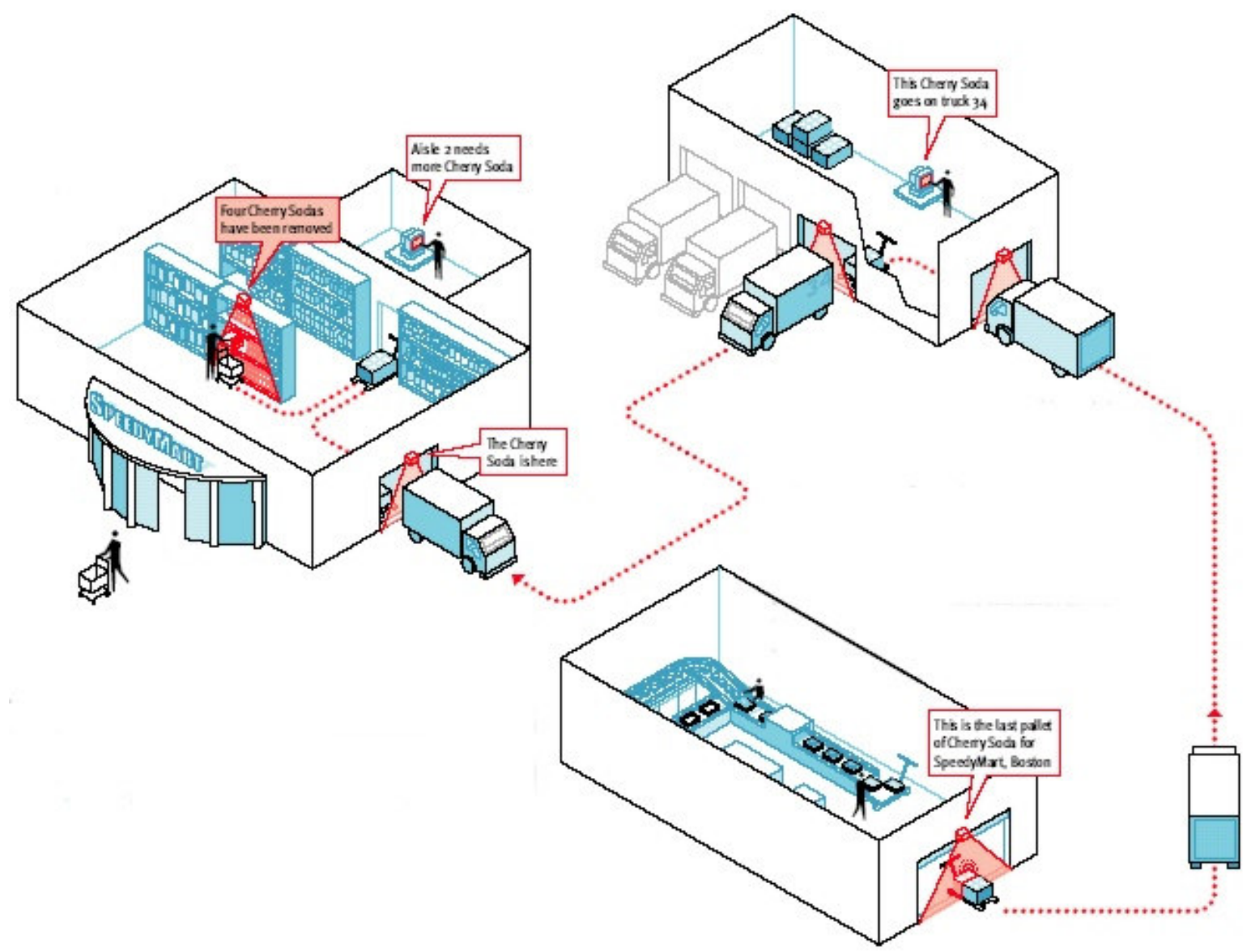

Figura 71 : Aplicação de identificação por rádio frequiência na cadeia de suprimentos Fonte: AUTO-ID CENTER (2002)

Poder-se-ia medir, efetivamente, o tempo de atividade de cada lote ou pedido, e utilizá-lo no custeio baseado em atividades cujo objeto de custeio seria cada canal de distribuição utilizado pela empresa, desse modo, fortalecendo a proposta de Kaplan e Anderson (2003). Entrementes a natural questão seria como lidar com o imenso amontoado de dados resultantes da aplicação da tecnologia.

Do estudo de caso realizado, pode-se inferir que tal problema não acarretaria grandes complicações ao atual sistema ERP, que utiliza código de barras nos itens do processo de injeção (conexões), visto que informações gerais sobre o tempo de atendimento do pedido já estão disponíveis.

Logo, tal tecnologia apresenta-se como uma solução ao problema da pesquisa, e corrobora as idéias levantadas pelos autores da revisão. Para arrematar o trabalho, serão apresentadas as conclusões e indicações para pesquisa futura. 


\section{CAPÍTULO 7 - CONCLUSÕES}

Depois de aplicado e analisado o custeio baseado em atividades como método para levantamento e custeamento de atividades logísticas de distribuição, evidenciado anteriormente, podem-se inferir algumas verdades, expostas adiante.

Nenhuma teoria duradoura plasma bases com mera expressão do seu tempo, das vicissitudes e contradições da história que lhe é contemporânea. Entrementes possui respostas aos problemas postos pela sua contemporaneidade. Nesse sentido, quando os custos são vistos por processos e atividades, tem-se um momento retratado. Nesse momento do processo, encontram-se as bases utilizadas para levar os custos dos recursos aos objetos. Tais bases, ou relações causais expressas, não são rijas ao longo do tempo. Daí a necessidade de atualização constante de grande volume de dados e conseqüente surgimento de dúvidas sobre os benefícios de implantação do custeio baseado em atividades.

Todavia, inegável avanço na utilização do custeio baseado em atividades encontra-se, em sua utilização, alinhada à medição da eficiência. Tempo e valor são expostos claramente, e medidas corretivas podem servir-se das relações causais evidenciadas.

Quanto à implantação do método na logística de distribuição, pode-se constatar carência na prospecção exata do tempo útil de cada atividade, no tratamento de atividades não freqüentes e, sobremaneira, na valorização da expertise do gestor responsável e executores das atividades. Tais lacunas originam-se, principalmente, pela adoção de entrevistas como alicerce dos fatores de distribuição dos custos.

Em contraste, as entrevistas mostram-se de grande valia, para modelar o processo. Este, resultante do mapeamento do fluxo de atividades, assemelha-se à ferramenta de fluxo de valor utilizada no pensamento enxuto, subtraindo-se os símbolos e representações. Assim, indicando novo campo para atuação do pensamento enxuto. De fato, abordado em elos anteriores à distribuição. 
Atendo-se à jusante do centro de distribuição, os problemas envolvendo estoque há muito são estudados, não, porém, sob a régua do pensamento enxuto. $\mathrm{O}$ jargão "o estoque é o colchão entre produção e demanda" ainda muito reflete a realidade. Pois, como verificado no estudo de caso, existem vários estoques intermediários e atividades que não agregam valor, apesar de custosas e demoradas.

Nesse ambiente, as relações entre volume e complexidade, no pensamento sobre custos logísticos, constituem o núcleo da reflexão sobre a gênese de um método de custeio eficaz e sobre o seu modo de funcionamento. Assim como a variável tempo deve ser contemplada de modo a contribuir para o correto custeamento dos objetos.

Como visto nas considerações sobre o estudo de caso, quanto mais complexo seja um pedido, mais tempo necessita-se para preenchê-lo, assim como existem atividades deveras demoradas, cujos custos não refletem os recursos consumidos. Para sanar tais erros, célebres autores tratam da variável tempo e complexidade de diferentes formas, adicionando maior precisão ao método de custeio baseado em atividades.

Paralelamente, presencia-se o surgimento da incipiente tecnologia de identificação por rádio frequiência. Método rápido, eficaz e de decrescentes custos, cuja inserção nos atuais ERP’s não traria barreiras computacionais intransponíveis.

Depois de ressaltadas as particularidades da aplicação do método de custeio baseado em atividades na logística de distribuição, decorre a indagação, o que de permanente e contingente pode-se extrair.

De permanente, destaca-se o método de entrevistas e observação in loco como meio de modelar e medir o processo logístico, o tratamento dos custos indiretos como diretos através do uso de direcionadores e agregação das contas por uma base causal. De contingente, têm-se as estimativas de tempo, tratamento planificado para atividades de diferentes complexidades e o fato de se julgar recursos desperdiçados como consumidos.

Por conseguinte, sugestiona-se pesquisa futura que trate os custos logísticos de distribuição, de modo a harmonizar o vislumbre do olhar por processo ao desejado mecânico e preciso sistema de custeio, de maneira tal que permita tratar de toda a cadeia de suprimentos. 


\section{REFERÊNCIAS}

ASSOCIAÇÃO BRASILEIRA DA INDÚSTRIA DO PLÁSTICO. (2004). Perfil Indústria Brasileira de Transformados Plásticos. Disponível em: http://www.abiplast.org.br/dados/estatisticas/a3.pdf?929626 . Acesso em: 15 nov. 2005.

ANDERSEN CONSULTING ARTHUR ANDERSEN (1994). Logistics strategy practice. In: ROBENSON, J.F.; COPACINO, W.C. (Ed.). The logistics handbook. New York: Free Press. Cap.12, p.251.

ANSARI, S.L. et al.. (1997). Target costing. Chicago: Irwin Professional.

ANSOFF, H.I. (1965). Corporate strategy. New York: McGraw-Hill.

AUTO-ID CENTER. (2002). Change the world. Disponível em: http://www.xplane.com/clients/autoid/ . Acesso em: 18 mar. 2005.

BALLOU, R. H. (1993). Logística empresarial. São Paulo: Atlas.

BALLOU, R.H. (2001). Gerenciamento da cadeia de suprimentos. Tradução de Elias Pereira. Porto Alegre: Bookman.

BOWERSOX, D.J.; CLOSS, D.J. (2001). Logística empresarial: o processo de integração da cadeia de suprimento. Tradução da equipe do centro de estudos em logística e Adalberto Ferreira das Neves. São Paulo: Atlas.

BOWERSOX, D.J.; CLOSS, D.J.; HELFERICH, O.K. (1986). Logistical management. $3^{\text {th }}$ ed. New York: Macmillan.

BRIMSON, J.A. (1996). Contabilidade por atividades: uma abordagem de custeio baseado em atividades. São Paulo: Atlas.

CARRILO JÚNIOR, E. (1992). Seminário de custos da logística no Brasil. São Paulo: Escola de Administração de Empresas de São Paulo, Fundação Getúlio Vargas. Apostila.

CARR, L.P.; ITTNER, C.D. (1992). Measuring the cost of ownership. Journal of Cost Management, Boston, v.6, n.3, p.42.

CASTRO, N.R. (2004). Logistic Costs and Brazilian Regional Development. The World Bank. Ago, 2004.

CENTRO DE ESTUDOS EM LOGÍSTICA (2006). Custos Logísticos na economia brasileira.

Disponível em:<http://www.centrodelogistica.com.br/new/art_custos_logisticos_economia_brasilei ra.pdf>. Acesso em: 24 de maio 2006. 
CHING, H.Y. (1999). Gestão de estoques na cadeia de logística integrada. São Paulo: Atlas.

CHRISTOPHER, M. (1997). Logística e gerenciamento da cadeia de suprimentos. São Paulo: Pioneira.

COMTE, A. (1978). Curso de filosofia positiva, discurso preliminar sobre o conjunto do positivismo, discurso sobre o espírito positivo. São Paulo: Abril Cultural.

COUNCIL OF SUPPLY CHAIN MANAGEMENT PROFESSIONALS (2005). Supply chain management/logistics management definitions. Disponível em:<http://www.cscmp.org/Website/AboutCSCMP/Definitions/Definitions.asp >. Acesso em: 10 jan. 2005.

COOPER, R. (1996). Target costing system. Worldwide business solutions: ERP optimisation.

Disponível em:<http://scholar.google.com/scholar?hl=en\&lr=\&q=cache:gLVGzWHp3u8J:www.w wbsgroup.com/pdf/article15.pdf+Toyota+Motor+Corporation:+Target+Costing+System >. Acesso em: 30 dez. 2004.

COOPER, R.; KAPLAN, R.S. (1998). Custo e desempenho: administre seus custos para ser mais competitivo. São Paulo: Futura.

(1999). How cost accounting distort product costs. Management Accounting, Montvale, p.20-27, Apr.

COPACINO, W.C. (1997). Supply chain management: the basics and beyond. Falls Creek: St.Lucie Press. (APICS Series on Resource Management).

COSTA, M.F.G. (2003). Gestão dos custos logísticos de distribuição. $256 \mathrm{p}$. Dissertação (Mestrado) - Faculdade de Economia, Administração e Contabilidade, Universidade de São Paulo, São Paulo, 2003.

CROW, K. (1998). Target costing. Disponível em:<http://members.aol.com/drmassoc/target.html>. Acesso em: 7 jan. 2005.

DANE, F.C. (1990). Research methods. Belmont: Brooks/Cole.

DEAN, E.B. (1998). Target and kaizen costing: perspective of competitive advantage. Disponível em:<http://akao.larc.nasa.gov/dfc/toc.html>. Acesso em: 16 dez. 2004.

DEGRAEVE, Z.; LABRO, E.; ROODHOOFT, F. (2000). An evaluation of vendor selection models from a total cost of ownership perspective. European Journal of Operational Research, Amsterdam, v.125, n. 1, p.34-58, Aug.

DEMO, P. (2001). Saber pensar. 2.ed. São Paulo: Cortez; Instituto Paulo Freire.

DORNIER, P.P. et al.. (2000). Logística e operações globais: texto e casos. São Paulo: Atlas. 
DUTTON, J.J. (1998). Target costing: a strategic business methodology. Visions Magazine, v.22, n.3. Disponível em:<http://www.pdma.org/visions/jul98/dutton.html $>$. Acessado em:10 Dez. 2004.

EISENDHARDT, K.M. (1989). Building theories from case study research. The Academy of Management Review, Briarcliff Manor, v.14, n.4, p.534-550, Oct.

ELLRAM, .L.M. (1995). Total cost of ownership an analysis approach for purchasing. International Journal of Physical Distribution \& Logistics Management, Bradford, v.25, n.8, p.4-23.

(1998). Activity-based costing and total cost of ownership: a critical linkage. Journal of Cost Management, Boston, v.8 n.4, p. 22-30.

EXAME: melhores e maiores (entre 2000 e 2005). Belo Horizonte, número especial.

FARIA, A.C. (2003). Uma abordagem na adequação das informações de controladoria à gestão da logística empresarial. 313p. Tese (Doutorado) - Faculdade de Economia, Administração e Contabilidade, Universidade de São Paulo, São Paulo, 2003.

FERREIRA, A.B.H.; ANJOS, M.; FERREIRA, M.B. (Coord.). (1999). Novo Aurélio século XXI. 3.ed. rev.e aum. Rio de Janeiro: Nova Fronteira. 1 CD-ROM.

FINANCIAL AND MANAGEMENT ACCOUTING COMMITTEE (1999). Target costing for effective cost management: product cost planning at Toyota Australia. New York.

FLEURY, P.F.; WANKE, P.; FIGUEIREDO, K.F. (2000). Logística empresarial: a perspectiva brasileira. São Paulo: Atlas.

FREEMAN, T. (1998). Transforming cost management into a strategic weapon. Hong Kong Industrial Technology Center Corporation. Disponível em:<http://www.cami.org/associations/3733/files/transforming.pdf>. Acesso em: 8 jan. 2005.

FREESE, T.L. (1999). Warehouse layout and design. Toronto: Freese and Associates Management and Logistics Management - CLM.

GATTORNA, J.L.; WALTERS, D.W. (1996). Managing the supply chain: a strategic perpective. London: Macmillan.

GAZETA MERCANTIL LATINO AMERICANA (2001). Atividade avança na América Latina. Disponível em:<http://www.infraestruturabrasil.gov.br $>$. Acesso em: 14 nov. 2004.

GIL, C.A. (1994). Métodos de pesquisa social. 4.ed. São Paulo: Atlas.

GONÇALVES, J.E.L. (1998). A necessidade de reinventar as empresas. Revista de Administração de Empresas, São Paulo, v.32, n.2, p.6-17, abr./jun. 
GURGEL, F.A. (2000). Logística industrial. São Paulo: Atlas.

HANSEN, D.R.; MOWEN, M.M. (2001). Gestão de custos. Tradução de Brian Taylor. Revisão técnica de Elias Pereira. São Paulo: Pioneira Thomson Learnig.

HARMON, R.L. (1994). Reinventando a distribuição. Rio de Janeiro: Campus.

HARRINGTON, H.J. (1993). Aperfeiçoamento dos processos empresariais. São Paulo: Makron Books.

HENDERSON, B.D. (1979). Henderson on corporate strategy. Cambrige: Abt Books.

HIJJAR, M. F. (2000). Segmentação de mercado para diferenciação dos serviços logísticos. Revista Tecnologistica, São Paulo, ano 5, n.51, p.18-24, fev.

HIJJAR, M. F. (2000). Diagnóstico externo do sistema logístico utilizando pesquisa de serviço ao cliente para identificação de oportunidades de melhorias. Centro de Estudos em Logística da COPPEAD. Rio de Janeiro. Disponível em:< http://www.coppead.ufrj.br/pesquisa/cel/>. Acesso em: 2 dez. 2004.

HRONEC, S.M.; ANDERSEN, A. (1994). Sinais vitais. São Paulo: Makron Books.

INSTITUTO BRASILEIRO DE CONTADORES (1995). NPC $n^{o}$ XXI: princípios contábeis - normas e procedimentos de auditoria. São Paulo: Atlas.

INSTITUTE OF MANAGEMENT ACCOUNTANTS (1992). Practices and techniques: cost management for logistics. Montvale. Statement Number 4-P.

KAPLAN, R.S. (1983). Measuring manufacturing performance: a new challenge for managerial accounting research. The Accounting Review, Sarasota, n.58, p.686-703, Oct.

KAPLAN, R.S.; COOPER, R. (1999). The design of cost management systems: text and cases. New Jersey: Prantice Hall.

KAPLAN, R. S. ; ANDERSON, S. R. (2003). Time-driven activity-based costing. Harvard Business School. Disponível em:< http://www.hbs.edu/research/facpubs/workingpapers/papers2/0304/04-045.pdf>. Acesso em: 15 mar. 2005.

KUMALA, H.I.; PARANKO, J.; YRJÄNÄINEN, J. L. (2000). A practical activitybased costing application in logistics business. In: CONFERENCE ON NEW DIRECTIONS IN MANAGEMENT ACCOUNTING: INNOVATION AN PRACTICE AND RESEARCH, 2., 2000, Bruxelas. Proceedings... Bruxelas: [s.n.]. p.483-500.

LAKATOS, E.M.; MARCONI, M.A. (1993). Fundamentos de metodologia científica. São Paulo: Atlas. 
LAMBERT, D.M.; STOCK, J.R.; VANTINE, J.G. (1998). Administração estratégica da logística. Tradução de Maria Cristina Vondrak. São Paulo: Vantine.

LAUCHLIN, K.A.; COPACINO, W.C. (1994). Logistics strategy. In: ROBESON, J.F.; COPACION, W.C. The logistics handbook. New York: The Free Press.

LIMA, M. (1999). Custos logísticos: uma visão gerencial. Rio de Janeiro. Disponível em:<http://www.coppead.ufrj.br/pesquisa/cel/new/fr-sist-info.htm>. Acesso em: 20 dez. 2004.

MANNING, K.H. (1998). Distribution channel profitability. Management Accountin, Montvale, v.76, n.7, p.44-48, Jan.

MARTINS, E. (1998). Contabilidade de custos. São Paulo: Atlas.

Paulo: Atlas.

(2001). Avaliação de empresas: da mensuração contábil à econômica. São

MILLER, J.; VOLLMANN, T. (1985). The hidden factory. Boston: Boston University.

MILLIGAN, B. (1999). Tracking total cost of ownership proves elusive. Boston: Purchasing.

MINAHAN, T. (1999). Attack cost at its roots. Disponível em:<http://www.manufacturing.net/magazine/purchasing/archives/1997/pur0306.97/03 1des.htm>. Acesso em: 20 out. 2004.

MINTZBERG, H. (1983). Power in and around organizations. New Jersey: Prentice Hall.

(1989). Mintzberg on managemant: inside our strange world of organizations. New York: Free Press.

MINTZBERG, H.; AHLSTRAND, B.; LAMPEL, J. (2000). Safári de estratégia: um roteiro pela selva do planejamento estratégico. Tradução de Nivaldo Montingelli Jr. Porto Alegre: Bookamn.

MONDEN, Y. (2001). Sistema de redução de custos. In: DIAS FILHO, F.F. $O$ aglomerado econômico e sua interferência na redução dos custos e na formação do preço de venda. Florianópolis: UFSC. p.38.

MUSETTI, M.A. (2000). A identificação da entidade gestora logística: uma contribuição para seu processo de formação e educação. 159p. Tese (Doutorado) Escola de Engenharia de São Carlos, Universidade de São Paulo, São Carlos, 2000.

NOVAES, A.G. (2001). Logística e gerenciamento da cadeia de distribuição. Rio de Janeiro: Campus.

NOVAES, A.G.N.; ALVARENGA, A.C. (2000). Logística aplicada: suprimentos e distribuição física. São Paulo: Pioneira. 
O'GUIN, M.C. (1991). The complete guide to activity-based costing. New Jersey: Prentice Hall.

OSTRENGA, M. R. et al.. (1993). Guia da Ernst \& Young para gestão total dos custos. Tradução de Nivaldo Montingelli Jr. Rio de Janeiro: Record.

POHLEN, T.L.; LALONDE, B.J. (1996). Issues in supply chain costing. International Journal of Logistics Management, Vedra Beach, v.7, n.1, p.1-12.

PORTER, M.E. (1989). Estratégia competitiva: técnicas para análise de indústrias e da concorrência. Tradução de Elizabeth Maria de Pinho Braga. 2.ed. Rio de Janeiro: Campus.

. (1985). Competitive advantage: creating and sustaining superior performance. New York: Free Press.

(1992). Vantagem competitiva: criando e sustentando um desempenho superior. Tradução de Elizabeth Maria de Pinho Braga. Rio de Janeiro: Campus.

ROBLES, A.J. (1996). Custos da qualidade: uma estratégia para competição global. São Paulo: Atlas.

ROBLES, L.T. (2001). A prestação de serviços de logística integrada na indústria automobilística no Brasil: em busca de alianças logísticas estratégicas. 176p. Tese (Doutorado) - Faculdade de Economia, Administração e Contabilidade, Universidade de São Paulo, São Paulo, 2001.

ROSENBLOOM, B. (2002). Canais de Marketing: Uma visão gerencial. São Paulo: Atlas.

RUMELT, R.P. (1997). The evaluation of business strategy. In: MINTZBERG, H.; QUINN, J. B. The strategy process. $3^{\text {th }}$ ed. Englewood Cliffs: Prentice Hall.

SAKURAI, M. (1989). Target costing and how to use it. Journal of Cost Management of the Manufacturing Industry, Boston, v.3, n.2, p.35-50, Summer.

(1995). Past and future of japanese cost management accounting. Journal of Cost Management, Boston, v.9, p.21-30, Fall.

SCARPIN, J.E. (2000). Target costing e sua utilização como mecanismo de formação de preço de venda para novos produtos. Dissertação (Mestrado) - Universidade Norte do Paraná, Londrina, 2000.

SHANK, J.K.; GOVINDARAJAN, V. (1997). A revolução dos custos. Tradução de Luiz O.C.Lemos. 2.ed. Rio de Janeiro: Campus.

STEINER, G.A. (1969). Top management planning. New York: Macmillan. 
STOCK, J. R.; LAMBERT, D.M. (2001). Strategic logistics management. $4^{\text {th }}$ ed. New York: McGraw-Hill Higher Education.

SUEMATSU, E. (2000). Planning and controlling the recovery of cash outflows through cash-flow costing. Journal of Cost Management, Boston, v.14, n.2, p.20-26.

TANAKA, T. (1993). Target costing at toyota. Journal of Cost Management, Boston,v.7, p.4-11, Spring.

THORPE, G. C. (1986). Pure Logistics: The science of war preparation. National Defense University Press. Washington, DC.

VERGARA, S.C. (2000). Projetos e relatórios de pesquisa em administração. São Paulo: Atlas.

VIÉGAS, P.E.D.; CALARGE, F.A. (1998). Custos da qualidade. In: SIMPÓSIO DE ENGENHARIA DE PRODUÇÃO, 5., 1998, Bauru. Anais... Bauru: Faculdade de Engenharia de Bauru/UNESP.

WOMACK, J.; JONES, D. (2004). Enxergando o todo: mapeando o fluxo de valor estendido. São Paulo: Lean Institute Brasil.

YIN, R.K. (2001). Estudo de caso: planejamento e métodos. Porto Alegre: Bookman

YRJÄNÄINEN, J.L.; PARANKO, J. (2001). A new approach to product costing in logistics business. In: INTERNATIONAL CONFERENCE ON PRODUCTION RESEARCH, 16., 2001, Praga. Proceedings... Amsterdam: Elsevier. 


\section{APÊNDICE A - Perguntas para entrevista}

\section{Cliente e definição de necessidades do cliente.}

1.1 Quem recebe seus produtos ou serviços?

Atualmente, os clientes que recebem os produtos e serviços do centro de distribuição da empresa são: construtoras, homecenters, órgãos públicos, clientes de exportação, clientes de varejo (revenda).

1.2 Que produtos a empresa fornece?

Linha tubos e conexões, linha sanitários (assentos, caixas de sanitários), linha de caixas d água, linha de forros e perfis.

1.3 Que atributos dos serviços oferecidos são mais importantes para os clientes da empresa?

O atributo mais importante para os clientes da empresa, hoje, é a entrega feita no prazo e com pedido integral, deste modo evitando duplas entregas para o mesmo pedido.

1.4 Que apoio fornece a eles?

Atualmente, a empresa fornece auxílio aos clientes em relação à armazenagem e separação dos produtos, bem como pré-agendamento de entregas. Assistências técnicas realizam a divulgação e treinamento de novos produtos junto aos clientes.

1.5 O que os clientes esperam da empresa? 
Os clientes da empresa esperam excelência de atendimento, ou seja, produtos entregues no prazo correto, sem faltas e sem avarias.

1.6 Que técnicas são usadas para confirmar as necessidades dos clientes?

Basicamente, o canal de comunicação com os clientes, em relação aos serviços logísticos, são as assistências técnicas. Estas fornecem o "feedback" para avaliação das necessidades dos clientes e cálculo de indicadores de desempenho da logística de distribuição.

1.7 Existe métrica que relacione metas e objetivos estratégicos com recursos destinados a elementos chaves do serviço ao cliente, tais como: disponibilidade do produto, tempo de ciclo do pedido, flexibilidade do sistema de distribuição, capacidade de resposta do sistema de distribuição, falhas no sistema de distribuição e suporte pós-venda?

As metas respeitadas se referem ao ciclo do pedido, tais como acolhimento, faturamento no prazo, faturamento integral e tempo de entrega de acordo à localização do cliente. E são metas destinadas por grupo de clientes.

\section{Estrutura da organização}

2.1 Descreva um quadro funcional de sua área.

A área atualmente emprega 275 pessoas, sendo que dessas 150 trabalham diretamente no faturamento, 60 pessoas trabalham com embalagem e armazenamento e 65 com manuseio de produtos nos pátios.

2.2 Identifique títulos e o número de pessoas.

O centro de distribuição opera em três turnos e possui uma estrutura organizacional de 6 níveis. No topo encontra-se um coordenador de equipe, abaixo tem-se 3 assistentes de distribuição, 1 analista de distribuição e no mesmo nível 
mais 3 escriturários administrativos. Abaixo tem-se 42 operadores de empilhadeiras elétricas, gás e trator, mais 3 operadores de computador e 3 escriturários administrativos. No nível inferior tem-se 62 conferentes de expedição, 5 ajudantes de expedição e um analista de suporte para microinformática. Abaixo, tem-se 18 compositores de pedidos e, como colaboradores fundamentais ao bom andamento dos processos da área, têm-se no sexto nível 133 ajudantes gerais.

2.3 Alguns funcionários se dedicam a determinados processos ou produtos?

Operadores de tratores, empilhadeiras de pátio, são específicos para tubos. Além da separação de pedidos, carregamento e conferência possuírem funcionários específicos.

\section{Definição de atividades}

\subsection{Descreva o fluxo do trabalho em sua área.}

Depois da saída do processo de produção a primeira ação que o centro de distribuição adota é realizar o "acolhimento", com coletor de dados, do produto produzido. Fisicamente o produto é levado para armazenagem, sendo que os tubos brancos são armazenados em pátios abertos, e ali ficam até o embarque. As conexões são armazenadas no interior de um armazém coberto e posteriormente são manuseadas para posições de estoque intermediárias até uma área de picking, neta área é feita a separação dos pedidos utilizando-se um coletor de códigos de barra. Após a separação, de acordo ao pedido, os produtos são alocados em boxes específicos para cada região de atendimento, por conseqüencia para cada transportadora. Tais boxes possuem número de localização que são evidenciados na nota fiscal do pedido que é entregue as transportadoras. Assim, com a localização do pedido os funcionários da transportadora se dirigem ao local descrito na nota e realizam o carregamento para o transporte ao cliente. $O$ carregamento é realizado de acordo a seqüência e rota determinada pela transportadora, sequiência esta descrita em um documento chamado de manifesto. 
3.2 Quais são as principais atividades executadas pela sua área?

A área possui 6 subprocessos. O primeiro subprocesso é a conferência de cargas, que é efetuada no carregamento dos caminhões. Durante o carregamento de tubos a conferencia é realizada pelos conferentes mais os ajudantes da própria transportadora, toda conferência é realizada via manifesto de carregamento, ou seja, uma conferência manual. Para conexões a conferência é realizada totalmente pelo coletor de dados, lendo-se uma etiqueta de código de barras do cliente que está em cada embalagem. No segundo subprocesso, o carregamento no pátio, as principais atividades são indicar o local de carregamento, realizar inspeção, carregar, lavar tubos, trocar tubos defeituosos e carregar os caminhões. O próximo subprocesso, armazenamento no pátio, possui como principais atividades indicar locais de armazenamento de produtos da fábrica e recebidos de outras fábricas da empresa. Bem como, realizar inspeção, lavagem, troca de itens defeituosos e o manuseio em si. Outro subprocesso é o acolhimento de produção e suas principais atividades são contar e liberar para o estoque, mediante leitura do código de barras dos produtos. Tem-se como subprocesso, também, o transporte interno por empilhadeira a gás e trator, que se refere ao armazenamento de produtos no pátio, após o acolhimento da produção e liberação pelo conferente de acolhimento. Outro subprocesso é o transporte interno por empilhadeiras elétricas, que como no pátio possui um conferente de acolhimento que libera, depois de acolhidos, os produtos para serem armazenados em locais pré-estabelecidos no interior do centro de distribuição. Ainda tem-se o subprocesso de separação de pedidos que consiste em atividades de separar os pedidos, embalar os pedidos, alocar os pedidos em locais pré-estabelecidos e emitir a nota fiscal. Tudo isto através do coletor de dados. E, por fim, tem-se o subprocesso central de embalagem, cujas principais atividades são gravar código de barras individual nas peças, enviar os produtos para central de embalagem, onde são automaticamente e manualmente embalados. Depois disso, disponibiliza-se os lotes para conferencia de leitura através do acolhimento e libera-se para armazenamento em local pré-estabelecido.

3.3 Como essas atividades se relacionam com os processos do negócio? 
Todos nossos subprocessos estão relacionados diretamente com a entrega final ao cliente, já que tais subprocessos são contínuos e influenciam toda a logística de distribuição. Por exemplo, devido ao acolhimento de produção, caso seja realizado inadequadamente, podem ocorrer faltas para o cliente final, pois a área de vendas baseia-se no que é produzido, e caso o acolhimento não seja realizado com a devida acurácia certamente faltaram produtos aos clientes. Do mesmo modo, na central de embalagem, caso os produtos não sejam etiquetados os produtos para cada cliente ocorrerá falta para o mesmo gerando transtorno, já que o pedido foi gerado e não atendido. No transporte interno caso seja danificada uma parcela de produtos poderá ocorrer falta ao cliente final. Na separação de pedidos, outro subprocesso da área, a satisfação do cliente está diretamente relacionada, pois caso um produto seja separado erradamente ou falte em um pedido gerará descontentamento do cliente.

\subsection{Quais são as principais responsabilidades do seu pessoal?}

As principais responsabilidades da equipe como um todo são o faturamento e a separação dos pedidos.

3.5 Qual é a sua estimativa da porcentagem de esforço requerido pela sua organização para apoiar cada uma das atividades? Descreva a lógica que usa para fazer essas estimativas.

No centro de distribuição, dividido nos seis subprocessos, o subprocesso que demanda mais custos é a separação de pedidos. Pois, tal subprocesso demanda cerca de 100 coletores de dados, sendo que o custo unitário de cada é de R \$ 5.000, e necessita-se de grande tempo para preparar o colaborador para operar o equipamento, no mínimo 3 meses. O segundo mais custoso é o subprocesso da central de embalagem, devido ao custo dos equipamentos de embalagem e aos altos custos de manutenção. O terceiro considero ser o transporte interno por empilhadeira a gás e elétrica, e por trator devido aos custos dos equipamentos, pois em média uma empilhadeira custa $\mathrm{R} \$ 100.000$ e um trator em torno de $\mathrm{R} \$$ 
120.000. Além disso, outro fator é o tempo de treinamento do operador. Os subprocessos que considero consumirem menor esforço são a conferência de cargas, carregamento no pátio e armazenamento no pátio, pois tais subprocesso exigem apenas serviços manuais, como manuseio, lavagem e reposição, que não exigem tanto esforço em capital e sim esforço físico.

3.6 Existem fatores que refletem a causa básica que a demanda de um objeto coloca sobre a atividade em relação a outros objetos?

No subprocesso de conferencia de cargas, a atividade de conferência via coletor de dados, será maior de acordo a demanda de vendas. No subprocesso de carregamento no pátio, a atividade de indicação do local de carregamento será maior de acordo a produção, quanto mais determinado produto é produzido mais inspeções serão feitas, mais lavagens e mais substituições de itens defeituosos. $\mathrm{Na}$ armazenagem, a indicação do local de armazenagem também será maior de acordo o aumento da produção, cita-se o tubo de $100 \mathrm{~mm}$ de diâmetro que funciona como parâmetro de aumento da produção, quando aquele aumenta todos os outros produtos aumentam. No acolhimento de produção, as atividades de conferência, leitura, liberação também variam de acordo a produção. $\mathrm{O}$ mesmo ocorre para o transporte interno, transporte no pátio e para central de embalagens. Na separação de pedidos, as atividades de leitura de etiqueta, embalar e emitir a nota fiscal estão relacionadas às vendas, quanto mais se vende mais pedidos tem-se que coletar, embalar e emitir nota fiscal. Como dito, no subprocesso de central de embalagens, a variação está relacionada à quantidade produzida. Pois, quanto maior a produção mais se etiqueta e mais se embala. De modo geral, para o armazenamento dos tubos, quanto mais pesado e maior a quantidade produzida, mais tempo é requerido para armazená-los. Na separação quanto menor pedido maior o esforço requerido. $\mathrm{Na}$ atividade de embalagem quanto mais complexa a forma do produto e maior a quantidade de peças no pedido, maior o tempo necessário para se realizar a operação. No acolhimento quanto menor o giro (demanda) mais rapidamente a atividade será realizada. 
3.7 Existem outros recursos importantes, além de pessoal (p. ex., equipamento), dedicados exclusivamente a determinadas atividades, processos ou produtos?

No armazenamento de tubos tem-se tratores exclusivos. Grandes contêiners, "gaiolões", utilizados para bobinas de dutos flexíveis (tigreflex), que permitem que o produto seja movimentado diretamente da produção para suas posições de armazenamento.

3.8 Quais sistemas utilizados na logística de distribuição (sistemas de planejamento e acompanhamento de estoques, sistemas de recebimento de pedidos de clientes, sistemas de medição de desempenho e outros sistemas de relatório, formais e informais)?

O sistema de controle utilizado na logística de distribuição é o ERP11-i, da Oracle.

\subsection{Como funcionam tais sistemas?}

Existem vários pontos de coleta de informação utilizados no acolhimento, separação e carregamento. Em cada função desejada o colaborador inicia a atividade inserindo seu código pessoal, daí em diante todo trajeto do produto é monitorado pelo sistema ERP da Oracle, através da leitura do código de barras inserido em etiquetas que acompanham os produtos. Deste modo, gera-se relatórios de acolhimento, separação e carregamento utilizados para registrar a quantidade de produtos existentes no armazém.

3.10 Que informações, relativas a medidas de trabalho e desempenho, estão disponíveis em tais sistemas?

Horas trabalhadas, número de pedidos atendidos dentro do prazo, número de caminhões carregados, o peso de cada pedido atendido, tempo de carregamento, tempo de atendimento de pedido, tempo de transporte, tempo de acolhimento, tempo requerido para aprovação do pedido, tempo requerido para ser faturado e se o pedido foi integralmente atendido. 